\title{
PERMAFROST AND THERMOKARST LAKE DYNAMICS IN THE OLD CROW FLATS, NORTHERN YUKON, CANADA
}

by

Pascale Roy-Léveillée

A thesis submitted to the Faculty of Graduate and Postdoctoral Affairs

in partial fulfillment of the requirements for the degree of

Doctor of Philosophy

in

Geography

Carleton University

Ottawa, Ontario

(C) 2014

Pascale Roy-Léveillée 


\section{Abstract}

Aspects of the thaw lake cycle were investigated in Old Crow Flats (OCF). OCF is a $5600 \mathrm{~km}^{2}$ peatland with thousands of thermokarst lakes in the continuous permafrost of northern Yukon. It is located in the traditional territory of the Vuntut Gwich'in, who expressed concern that climatic change may be affecting the permafrost and lakes of OCF.

Field data collected in 2008-2011 provided the first assessment of spatial variability in permafrost temperatures across the treeline ecotone in OCF. Lake-bottom temperatures were recorded near the shores of four thermokarst lakes and talik configuration was defined beneath the lakes by jet-drilling to determine conditions controlling permafrost degradation in the area. Analytical and thermal models were used to relate field observations to current theory. Surface and subsurface conditions were examined in three drained lake basins and four expanding lakes to investigate how shore recession, talik development, and sediment deposition during lake expansion control the topography in lake basins after drainage.

Permafrost temperature at the depth of zero annual amplitude varied between $-5.1^{\circ} \mathrm{C}$ and $-2.6^{\circ} \mathrm{C}$ on the Flats. Within the forest-tundra transition, spatial variability in permafrost temperatures appeared to be controlled by the snow-holding capacity of vegetation and the configuration of land covers in the surrounding landscape, which controlled snow supply. Annual mean lake-bottom temperatures close to shorelines were unaffected by spatial variations in on-ice snow depth, but accumulation of freezing degree-days at the lake bottom varied sufficiently to affect rates of permafrost degradation beneath the lake. Where ice reached the lake bottom, talik development rates were controlled by the ratio of freezing degree days to thawing degree days and the thermal offset in the lake 
sediment. After lake drainage and permafrost aggradation, thermokarst lake basins in OCF commonly develop depressed margins and raised centres. An elevation difference of up to $2 \mathrm{~m}$ was recorded between the margins and centres of drained basins, but this elevation difference was not associated with increased ice-wedge density or increased segregated ice content. A conceptual model based on sediment deposition patterns during lake expansion was proposed to explain the topography of drained lake basins in $\mathrm{OCF}$. 


\section{Preface}

\section{Integrated manuscripts}

Chapters 4, 5, and 6 of this thesis are drawn directly from manuscripts that have been published, were in review for publication, or in preparation as a journal article at the time of thesis submission. The original citations for the material presented in these chapters are:

Chapter 4: Ground temperatures in the Old Crow area, published as: Roy-Léveillée P, Burn CR, McDonald ID. (Accepted on February 9, 2014) Vegetation-permafrost relations within the treeline ecotone near Old Crow, northern Yukon, Canada. Permafrost and Periglacial Processes, 25:127-135, doi:10.1002/ppp.1805.

Chapter 5: Talik development near thermokarst shorelines, has been submitted to Journal of Geophysical Research - Earth Surface as: Roy-Léveillée P, Burn CR. Near-shore talik development beneath expanding thermokarst lakes, Old Crow Flats, Yukon, Canada. (returned for revisions, on August 16th, 2014).

Chapter 6: Topography in drained lake basins, is in preparation for submission to Earth Surface Processes and Landforms as: Roy-Léveillée P, Burn CR. Internal topography of drained lake basins, Old Crow Flats, Yukon, Canada.

Additional non-refereed research contributions related to this thesis are listed in Appendix B, including community outreach material. The research presented in this thesis was part of an International Polar Year Project led by the

Vuntut Gwitchin First Nation. Community outreach was a major component of the 
research communication for the project.

\section{Statement of co-authorship}

Chapters 4, 5, and 6 of this thesis are drawn from papers that have been submitted for publication in refereed journals as co-authored articles. The authors of each article have read and signed the following two statements outlining the role of Pascale Roy-Léveillée as principal investigator and main author on each publication:

"As co-author of 'Vegetation-permafrost relations within the treeline ecotone near Old Crow, northern Yukon, Canada', published in the peer-reviewed journal Permafrost and Periglacial Processes, of 'Near-shore talik development beneath expanding thermokarst lakes, Old Crow Flats, Yukon, Canada', submitted for publication to the Journal of Geophysical Research, and of 'Topography of drained lake basins in the Old Crow Flats, Y.T.', to be submitted for publication to Earth Surface Processes and Landforms, I, Christopher Robert Burn, acknowledge Pascale Roy-Léveillée as the lead contributing author of these manuscripts. Pascale designed and performed the field study, obtained and analysed all data, and wrote and revised the manuscripts.

I, Christopher Robert Burn, have contributed to the published papers and the papers submitted for publication in this thesis as supervisor of Pascale Roy-Léveillée during the doctoral program in geography. This has entailed discussion, criticism, advice, and editorial contributions to the design, field investigations, analysis, and writing of this thesis. These activities have been entirely consistent with the role of thesis supervisor.

As co-author of 'Vegetation-permafrost relations within the treeline ecotone near Old Crow, northern Yukon, Canada', published in the peer-reviewed journal Permafrost and Periglacial Processes, I, Ian Douglas McDonald, acknowledge 
Pascale Roy-Léveillée as the manuscripts' lead contributing author. Pascale designed and performed the field study, obtained and analysed all data, and wrote and revised the manuscripts. I, Ian Douglas McDonald, have contributed to the published paper in this thesis as a northern research partner. This has entailed contribution to the collection of field data, discussion, criticism, and editorial contributions to the design of field investigations, and writing of the manuscript. These activities have been entirely consistent with the role of northern research partner.

These manuscripts have engaged topics that have been the subject of some discussion in the literature, and represent significant contributions to the understanding of permafrost and permafrost-related processes. For this reasons we fully support the inclusion of these articles as a component in Pascale's doctoral thesis."

Signed statements are included in Appendix A. 


\section{Acknowledgements}

This thesis would not have been completed without the support of several people and organisations.

The research was funded by the Government of Canada International Polar Year Program, the Northern Research Chair Program of the National Science and Engineering Research Council, the Polar Continental Shelf Program, and the Northern Scientific Training Program. Essential logistical support was provided by the Vuntut Gwitchin First Nation and the Aurora Research Institute. The Yukon Field Unit of Parks Canada provided in-kind support.

Several people contributed to data collection as field assistants or guides: Alexander Jarvo, Ashlyn Leanne Frost, Blayne Brown, Chistina Zo Braul, Dennis Frost, Douglas Charlie, Erika Tizya-Tramm, Georges Nukon, Kibbe Tetlichi, Lance Nagwan, Marvin Frost Jr., Samantha Frost, Stan Njoutli, Stephen Frost, and Sian Williams. Stanley, Kibbe, Erika, Douggie, Steven, Dennis, and Georges improved my understanding of the Flats through the sharing of stories, experience, ideas, or observations while out in the field. Lance and Marvin Jr. made a difficult winter trip seem easy, made $-35^{\circ} \mathrm{C}$ seem balmy, and offered perfect company at a time where grief made it hard for me to relate to most people. Special thanks to Samantha, Zo, and Ashlyn who verified that the very physical work of jet-drilling and permafrost coring can be done by an all women field crew. Working with you was a privilege and an amazing experience for which I am very grateful. Thanks also to Shell Graupe and Stephen Frost who supported the proposition of an all women field expedition. Renee Charlie, Megan Williams, Jessica Wrench, Edna Kyikavichik and Vernon Kyikavichik facilitated relations with the local community and provided invaluable logistical support as people, planes, helicopters, food, and 
equipment transited through Old Crow on the way to Old Crow Flats and back. Thanks to Blacksheep Aviation for transportation, delivery of fruit and camembert, and voluntary field assistance during the summer of 2011.

Josh Thienpoint, Elyn Humphreys, and Jesse Vermaire provided assistance with the preparation of samples for radiocarbon dating, and Duane Froese dated peat-bottom samples. Tim Patterson and Micheal Pisaric's laboratory facilities were used for particle-size analysis and loss on ignition. Carley Crann and Colin Mustaphi facilitated proper use of this equipment. Trevor Porter provided tree-coring tools.

Thank you to my supervisor, Christopher Burn, for continued guidance and support through my PhD. Chris, I have worked under your supervision for nearly ten years. These years were rich in learning opportunities and challenges beyond anything I could have imagined when I applied to Carleton University. Thank you for giving me the opportunity to be one of your students and the chance to work on the Old Crow project. You have been very generous with your time and I am very grateful. I will strive to pass on what I have learned to future generation of students.

My committee members, Antoni Lewkowicz, Sean Carey, and Stephan Gruber, provided helpful advice and encouraged me to think more deeply about my research results. Stephen Wolfe, Steve Kokelj, Ian McDonald, Kenneth Hinkel, Bernard Lauriol, and Jim Bockheim provided helpful suggestions to improve the integrated manuscripts. Discussions with Kumari Karunaratne, Peter Morse, Marcus Phillips, Brendan O'Neill, Sasha Zemskova, Adrian Gaanderse, Jon Tunnicliffe, Zanju Lin, Trevor Lantz, Ann Balasubramaniam, and Kevin Turner helped refine the ideas presented in this thesis. Special thanks also to Iain Wallace and the 2007-08 cohort for discussions that allowed me to reflect critically on the human aspects of permafrost science. 
Several friends provided support through the last few years. Anita Kushwaha provided advice, inspiration, moral support, writing assistance, and company through the PhD program. Florence Heung helped me increase my awareness of power dynamics, challenged me to to be self-reflective, and encouraged me to be true to myself, always. Troy Pretzlaw was (at most!) a phone call away through the whole project to provide advice and assistance with just about everything. The folks at the Carleton Aikido Club, especially Boris Ionine, Rita Kiapway, Danny Schwartz, and Jana Huismans, assisted greatly with stress management.

Thank you to my mother, Jacqueline Roy, for help while packing, shipping, and unpacking equipment, samples, and personal belongings, for assistance in the lab, for rides to the airport, for unlikely enthusiasm in front of my results graphs, and for emergency moral support. Thanks to Jocelyne for her support as well. Thank you to my ever patient, tolerant, and accommodating partner Pascal Renard, who kept having all the qualities I ran out of as I was struggling to finish this thesis 'on time'. Finally special thanks go to my daughter Anas-Camille, who has helped me develop time-management skills I had never dreamed of having. 


\section{Table of Contents}

Abstract .................................... iii

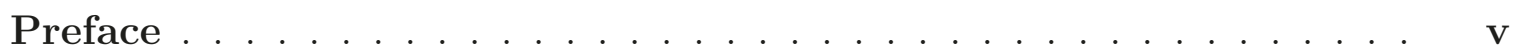

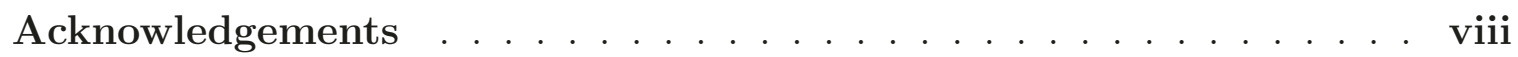

List of abbreviations and symbols $\ldots \ldots \ldots \ldots$. . . . . . . . xiv

\begin{tabular}{lll}
\hline I Introductory chapters & 1
\end{tabular}

Chapter 1 Overview and objectives . . . . . . . . . . . . 2

1.1 Introduction . . . . . . . . . . . . . . . . . . . . . 2

1.2 Old Crow Flats $\ldots \ldots \ldots \ldots \ldots \ldots \ldots$

1.3 Research objectives $\ldots \ldots \ldots \ldots \ldots \ldots \ldots \ldots$

1.4 Thesis structure $\ldots \ldots \ldots \ldots \ldots$

Chapter 2 Background $\ldots \ldots \ldots \ldots$

2.1 Introduction $\ldots \ldots \ldots \ldots \ldots$

2.2 Permafrost $\ldots \ldots \ldots \ldots \ldots$

$2.2 .1 \quad$ Definition and significance $\ldots \ldots \ldots \ldots$

2.2 .2 Thermal properties $\ldots \ldots \ldots \ldots \ldots \ldots$

2.2 .3 Thermal regime $\ldots \ldots \ldots \ldots \ldots$

2.2 .4 Active-layer thermal regime $\ldots \ldots \ldots \ldots \ldots$ 
2.2 .5 Snow cover . . . . . . . . . . . . . . . . . . . 18

2.2 .6 Thermal condition in the forest-tundra ecotone . . . . . . 18

2.3 Ground ice. . . . . . . . . . . . . . . . . . . . . . . . . 20

$2.3 .1 \quad$ Definitions and significance $\ldots \ldots \ldots \ldots$

2.3 .2 Pore ice . . . . . . . . . . . . . . . . . . . . . . . . 21

$2.3 .3 \quad$ Segregated ice . . . . . . . . . . . . . . . . . . . . . 21

$2.3 .4 \quad$ Aggradational ice . . . . . . . . . . . . . . . . . . . 22

$2.3 .5 \quad$ Ice wedges $\ldots \ldots \ldots \ldots \ldots \ldots \ldots$

2.3 .6 Ground ice in glaciolacustrine environments $\ldots \ldots$. . . . 27

2.3 .7 Ground ice in drained lake basins . . . . . . . . . . . 27

2.4 Thermokarst lakes $\ldots \ldots \ldots \ldots \ldots$

$2.4 .1 \quad$ Definitions and significance $\ldots \ldots \ldots \ldots \ldots$

$2.4 .2 \quad$ Talik development $\ldots \ldots \ldots \ldots$

2.4 .3 Controls on lake bathymetry . . . . . . . . . . . . . 30

2.4 .4 Shore erosion and lake expansion . . . . . . . . . . . . 30

2.4 .5 Controls on lake geometry and orientation . . . . . . . . 32

$2.4 .6 \quad$ Lake drainage and permafrost recovery . . . . . . . . . . . 32

2.5 Study area: Old Crow Flats, Yukon $\ldots \ldots \ldots \ldots$

2.5 .1 Introduction: physiography and cultural significance. . . . . . 34

$2.5 .2 \quad$ Geological structure and surficial deposits . . . . . . . . 36

2.5 .3 Permafrost . . . . . . . . . . . . . . . . . . . 37

2.5 .4 Thermokarst lakes . . . . . . . . . . . . . . 38

2.5 .5 Vegetation . . . . . . . . . . . . . . . . . . . 39

$2.5 .6 \quad$ Hydrology . . . . . . . . . . . . . . . . . . . . . . 40

2.5 .7 Climate $\ldots \ldots \ldots \ldots \ldots \ldots \ldots$ 
$2.6 \quad$ Summary and concluding remarks . . . . . . . . . . . . . . . . . . . . 44

Chapter 3 Methods . . . . . . . . . . . . . . . . . . 45

3.1 Introduction . . . . . . . . . . . . . . . . . . . . . . . . 45

3.2 Approach to community participation . . . . . . . . . . . . . . 46

3.3 Field-based research . . . . . . . . . . . . . . . . . . . . . . . . 48

3.4 Complementary use of remotely-sensed images and numerical models $\quad 49$

$3.5 \quad$ Extensive and intensive approaches to study thermokarst lakes . . . . 50

3.5.1 The use of cases in this research . . . . . . . . . . . . . . . . . 51

3.5.2 The selection of cases . . . . . . . . . . . . . . . . 52

3.6 Key methods and limitations . . . . . . . . . . . . . . . . 56

3.6 .1 Temperature measurements . . . . . . . . . . . . 57

3.6 .2 Delineation of talik geometry . . . . . . . . . . . . . . . 61

3.6 .3 Estimation of segregated ice content . . . . . . . . . . 63

3.6 .4 Sediment-texture analysis . . . . . . . . . . . . 65

3.6.5 Representation of $\theta_{u}$ for numerical modelling . . . . . . . . . . 66

\begin{tabular}{lll}
\hline II $\quad$ Integrated publications & 67
\end{tabular}

Chapter $4 \quad$ Ground temperatures in the Old Crow area . . . . . . . 68

4.1 Introduction $\ldots \ldots \ldots \ldots$

4.2 Field methods . . . . . . . . . . . . . . . . . . . . . . . . . . . . . . . . . 69

4.3 Study sites . . . . . . . . . . . . . . . . . . . . . . . . 73 
4.3.1 Site 1: taiga with a tall shrub understorey (Taiga-TS) . . . 73

4.3.2 Site 2: taiga with a low shrub and sedge understorey (Taiga-LS) 73

4.3 .3 Site 3 : tall shrubs and taiga . . . . . . . . . . . . . . . 74

4.3 .4 Site 4: low shrubs and sedges . . . . . . . . . . . . . . . 74

4.4 Results . . . . . . . . . . . . . . . . . . . . . . . . 75

4.4 .1 Air temperature . . . . . . . . . . . . . . 75

4.4 .2 Snow-pack characteristics and vegetation cover. . . . . . . . . 75

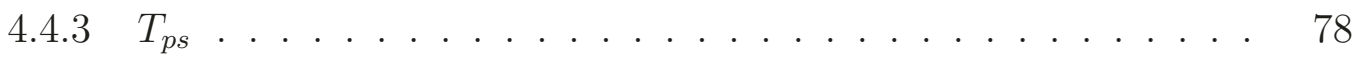

$4.4 .4 \quad T_{g}$ and the annual thermal envelope . . . . . . . . . . . 81

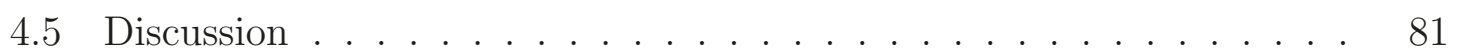

4.6 Conclusions $\ldots \ldots \ldots \ldots$

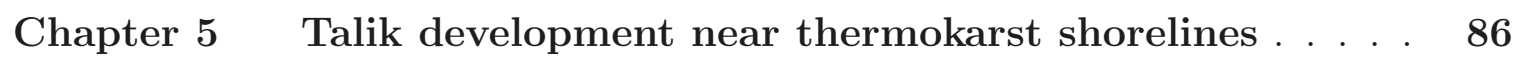

5.1 Introduction . . . . . . . . . . . . . . . . 86

5.2 Background: thermokarst lake development . . . . . . . . . . . . . . 88

5.3 Study area . . . . . . . . . . . . . . . . . . . . . . . . . . 89

5.4 Methods . . . . . . . . . . . . . . . . . . . . . . . 9 90

5.4 .1 Field methods . . . . . . . . . . . . . . . . . . . . . . . . . . . 90

5.4 .2 Ground material properties . . . . . . . . . . . . . . . . 93

5.4 .3 Determination of shore recession rates . . . . . . . . . . . . . 94

5.4 .4 Analytical model of thaw penetration . . . . . . . . . . . 94

5.4 .5 Numerical simulations . . . . . . . . . . . . . . . . . . . . . . . 99

5.5 Field results . . . . . . . . . . . . . . . . . . . . . . . . . . . . . 102 
5.5 .1 Climate data . . . . . . . . . . . . . . . . . 102

5.5 .2 Permafrost conditions . . . . . . . . . . . . . 105

5.5 .3 Lake ice and snow cover . . . . . . . . . . . . . . . 105

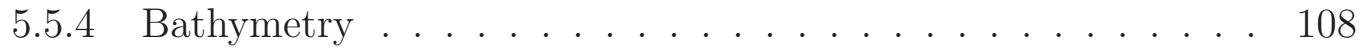

5.5 .5 Lake-bottom temperatures . . . . . . . . . . . . . . . . . 108

$5.5 .6 \quad$ Frost penetration in the lake bottom . . . . . . . . . . . 109

5.5 .7 Shoreline recession . . . . . . . . . . . . . . . . . . . 109

5.5 .8 Talik geometry $\ldots \ldots \ldots \ldots \ldots$

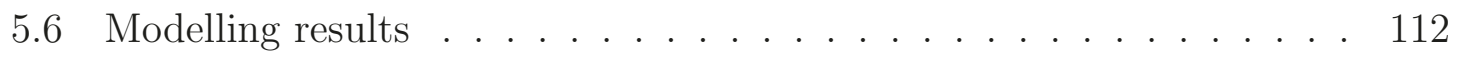

5.6 .1 Talik geometry and the Stefan solution . . . . . . . . . . 112

5.6 .2 Talik initiation and interannual variations . . . . . . . 115

5.6.3 Permafrost degradation rates and amplitude of the annual lakebottom thermal regime . . . . . . . . . . . . . . . 115

5.6 .4 Talik refreezing with $T_{l b}>0^{\circ} \mathrm{C} \ldots \ldots \ldots \ldots$

5.7 Discussion $\ldots \ldots \ldots \ldots \ldots \ldots$

5.7 .1 Lake-bottom temperatures beneath shallow water . . . . . . 120

5.7 .2 Talik initiation beneath shallow water. . . . . . . . . . 121

5.7 .3 Talik geometry near receding shores in shallow lakes. . . . . . 124

5.7 .4 Temporal resolution $\ldots \ldots \ldots \ldots \ldots$

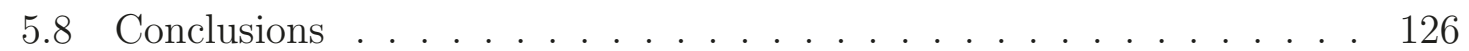

Chapter 6 Topography of drained lake basins . . . . . . . . . 128

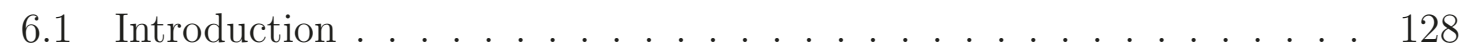

6.2 Thermokarst lake sediments . . . . . . . . . . . . . . . . . . . . 129 
6.3 Methods . . . . . . . . . . . . . . . . . . . . . . . . 133

$6.3 .1 \quad$ Selection of study sites $\ldots \ldots \ldots$. . . . . . . . . . 133

6.3.2 Lake-bottom conditions and shore recession prior to drainage. 133

6.3 .3 Relief, vegetation cover, and thermal conditions in drained basins 135

6.3 .4 Sediment texture and segregated ice content . . . . . . . . 137

$6.3 .5 \quad$ Ice-wedge distribution $\ldots \ldots \ldots \ldots \ldots$

6.3.6 $\quad$ Time since drainage and depth of permafrost aggradation. . . 139

6.4 Results . . . . . . . . . . . . . . . . . . . . . . . . . . . . . . . 140

$6.4 .1 \quad$ Basin morphometry . . . . . . . . . . . . . . . . . . 140

6.4.2 Lake-bottom conditions and shore recession prior to drainage. 145

6.4 .3 Time since drainage and depth of permafrost aggradation. . . 148

6.4 .4 Topography . . . . . . . . . . . . . . . . . . . . 150

6.4 .5 Vegetation, snow cover, and thermal conditions . . . . . . 150

6.4.6 Organic-layer thickness and texture at the top of mineral soil. 154

6.4 .7 Excess-ice content and topography $\ldots \ldots \ldots \ldots \ldots$

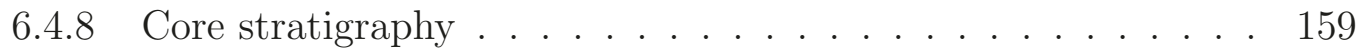

6.5 Discussion $\ldots \ldots \ldots \ldots$

$6.5 .1 \quad$ Drained basin topography $\ldots \ldots \ldots \ldots \ldots$

$6.5 .2 \quad$ Basin topography and excess-ice content . . . . . . . . 165

$6.5 .3 \quad$ Sediment available for frost heaving . . . . . . . . . . . 168

6.5.4 Model for the internal topography of drained basins in Old

Crow Flats . . . . . . . . . . . . . . . . 170

6.5 .5 Controls on the width of depressed margins $\ldots \ldots \ldots$

$6.6 \quad$ Summary and conclusions $\ldots \ldots \ldots \ldots$

xvi 
\begin{tabular}{lll}
\hline III Concluding chapters & 174
\end{tabular}

\begin{tabular}{lll}
\hline Chapter 7 & Summary, implications, and future work $\ldots \ldots . . .175$
\end{tabular}

7.1 Introduction . . . . . . . . . . . . . . . . . . . . . . 175

7.2 Summary of findings and significance $\ldots \ldots \ldots \ldots \ldots$

7.2 .1 Permafrost temperatures in the Old Crow area . . . . . . . . 175

7.2 .2 Talik development near thermokarst shores . . . . . . . . . . 177

7.2 .3 Drained basin topography $\ldots \ldots \ldots$. . . . . . . . . . . . . 179

7.3 Directions for further research $\ldots \ldots \ldots \ldots$. . . . . . . . . 181

7.3.1 $\quad$ Permafrost temperature within the forest-tundra ecotone . . . 181

7.3 .2 Permafrost aggradation in drained basins . . . . . . . . . . 182

$7.3 .3 \quad$ Permafrost degradation beneath shallow water . . . . . . . . 182

7.3 .4 The thermokarst lake cycle in Old Crow Flats . . . . . . . 183

Bibliography ... . . . . . . . . . . . . . . . . 184

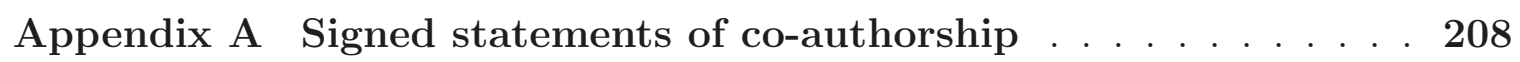

Appendix B Other contributions related to this research . . . . . 210

xvii 


\section{List of Tables}

$2.1 \quad$ Thermal properties of typical soil constituents . . . . . . . . . 12

$2.2 \quad$ Rates of lake-shore recession from various regions . . . . . . . . 31

$3.1 \quad$ Annual mean ground temperature measured in 5 boreholes in August 2009, May 2010, March 2010 . . . . . . . . . . . . . . . 60

$3.2 \quad$ Annual mean ground temperature in three boreholes located 5, 50 , and $100 \mathrm{~m}$ from shore . . . . . . . . . . . . . . . 62

$4.1 \quad$ Mean air temperature, freezing degree days, and thawing degree days at Old Crow and in Old Crow Flats . . . . . . . . . . . 77

$4.2 \quad$ Annual mean temeprature at the top of permafrost between 2008 and 2010 under different vegetation covers . . . . . . . . . . . . 79

$4.3 \quad$ Annual mean ground temperature at sites 1 to 4 (2009-13) . . . 82

$5.1 \quad$ Lakeshore morphology, vegetation cover, and water depth at the study sites . . . . . . . . . . . . . . . . . . . . . . . . 92

$5.2 \quad$ List of equations used in Chapter 5 . . . . . . . . . . . . . 95

$5.3 \quad$ Ground properties and boundary conditions used for simulations of talik development . . . . . . . . . . . . . . . . . . . . . . . 97

$5.4 \quad$ Porosity, excess ice, and organic matter content in two lakebottom permafrost cores . . . . . . . . . . . . . . . . . . . . 98

$5.5 \quad$ Mean air temperature, freezing degree days, and precipitation at Old Crow from September $1^{\text {st }}$ to August $31^{\text {st }}, 2008-11$. . . . 103 
$5.6 \quad$ Mean temperature at the top of permafrost and mean snow depth at sites 2 to 4 . . . . . . . . . . . . . 104

$5.7 \quad$ Annual mean lake-bottom temperature, freezing degree days, and date of contact between ice and sediment at the sites . . . 106

$5.8 \quad$ Distance from the shoreline to the edge of the talik and conditions associated with talik initiation . . . . . . . . . . . . . . . 111

$5.9 \quad$ Rates of shoreline erosion at each study site . . . . . . . . . . . 114

$6.1 \quad$ Wave length and wave base calculated based on the mean wind speed recorded during the open water season . . . . . . . . . . 146

$6.2 \quad$ Ground properties and thermal conditions used to simulate depth of permafrost aggradation with the Stefan solution . . . . . . . 152

6.3 Mean temperature at the permafrost surface and snow depth in the margins and centres of basins 1 to 3 . . . . . . . . . . . 153 


\section{List of Figures}

$1.1 \quad$ Location map and Landsat ETM image of Old Crow Flats . . 3

2.1 Circumpolar distribution of permafrost . . . . . . . . . 10

2.2 Gravimetric unfrozen water content of various soils . . . . . 14

2.3 The thermal regime of permafrost . . . . . . . . 16

2.4 Examples of ice-wedge polygon patterns . . . . . . . 25

2.5 Classification system for ice-wedge polygons in flat areas . . . 26

2.6 Factors controlling the thermal regime of permafrost . . . . 35

2.7 Climatic normal (1981-2010) air temperature and precipitation at Old Crow . . . . . . . . . . . . . . . 43

$3.1 \quad$ Location of the instrumented sites . . . . . . . . . . . . . 54

3.2 Field installations for the measurement of air temperature and top of permafrost temperatures ........... 58

3.5 Gravimetric, volumetric, and \% unfrozen water content curves for Athena silt loam . . . . . . . . . . . . . . . . . 64

$4.1 \quad$ Old Crow Flats and Permafrost monitoring sites . . . . . . . . 70

4.2 Photographs of ground temperature monitoring sites . . . . 71

4.3 (a)Relation between snow depth and canopy heith, and (b) relation between $T_{p s}$ and snow depth ......... . 76

4.4 Near-surface permafrost temperature regime and vegetation . 80 
4.5 Examples of ground temperature envelopes from site 2 and site 483

$5.1 \quad$ Northern Yukon with extent of Glacial Lake Old Crow, Landsat 7 image of Old Crow Flats, and location of study sites . . . . 87

5.2 The four shorelines from which transects were extended over lake ice to measure snow depth, lake depth, lake-bottom temperature, and talik depth . . . . . . . . . . . . . . . 91

5.3 Near-shore bathymetry and snow depth at the four transects . 107

5.4 Near-shore bathymetry and snow depth at the four transects . 110

5.5 Near-shore talik depth relative to the ice surface . . . . . 113

5.7 The first 15 years of talik initiation and development after submergence.................... 116

5.8 Talik development rates simulated numerically based on six ground thermal regimes of varying amplitude . . . . . . . . . 117

5.9 Talik development and refreezing with six different lake-bottom thermal regimes applied after a talik has developed to a depth of $6.9 \mathrm{~m} \ldots \ldots \ldots \ldots \ldots$

6.1 Map of the Old Crow area, Landsat image of Old Crow Flats, and location of study sites . . . . . . . . . . . . . . . 130

$6.2 \quad$ Lakes and drained basins in the area surrounding the basins selected for field study . . . . . . . . . . . . . . . . . . . . . 136

6.3 Two example drained basins shown on vertical aerial photographs142 
6.4 Aerial photographs of basins 1, 2 and 3 showing the location of the surveyed transects . . . . . . . . . . . . . . . . 143

6.5 Bathymetric map of Lake 1) and SW-NE profiles from three neighboring lakes . . . . . . . . . . . . . . . . . . 144

6.6 Lake-bottom sediment texture and median particle size along the bottom of Lake $1 \ldots \ldots$. . . . . . . . . . 147

6.7 Shoreline position in 1951 and 2007 for lakes 1 to $4 \ldots \ldots$

6.8 Relative elevation along transects in basins 1,2 and $3 \ldots 151$

6.9 Ground-surface elevation plotted against organic-layer thickness and against thaw depth . . . . . . . . . . . 156

6.10 Sediment texture at the top of the mineral soil in the basin margins and centres . . . . . . . . . . . . . 157

6.11 Distribution of ice-wedge troughs in and around basin $1 \ldots 158$

6.12 Subsidence potential in margins and centres plotted against median particle size, organic layer thickness, and elevation . . . . 160

$6.13 \quad$ Example core stratigraphies from basin $1 \ldots \ldots \ldots 16$

$6.14 \quad$ Example core stratigraphies from basin $2 \ldots \ldots \ldots$

6.15 Conceptual model of sedimentation patterns during lake expansion and resulting topography after drainage and permafrost agradation . . . . . . . . . . . . . . . . . 171

xxii 


\title{
List of abbreviations and symbols
}

\author{
$\left[\boldsymbol{B}_{j}\right] \quad$ Gradient matrix \\ $C_{a} \quad$ Apparent volumetric heat capacity of frozen unfrozen soil, \\ including latent heat effects $\left(\mathrm{J} \mathrm{m}^{-3{ }^{\circ}} \mathrm{C}^{-1}\right)$ \\ $\boldsymbol{C}_{\boldsymbol{i}, \boldsymbol{w}, \boldsymbol{o}, \boldsymbol{m}} \quad$ Volumetric heat capacity of ice, water, organic material, min- \\ eral soil $\left(\mathrm{J} \mathrm{m}^{-3 \circ} \mathrm{C}^{-1}\right)$ \\ $\boldsymbol{C}_{\boldsymbol{f}, \boldsymbol{t}} \quad$ Volumetric heat capacity of frozen and unfrozen soil (J \\ $\left.\mathrm{m}^{-3 \circ} \mathrm{C}^{-1}\right)$
}

CRREL Cold Regions Research and Engineering Laboratory of the United States Army Corps of Engineers

$\boldsymbol{d} \quad$ Water depth $(\mathrm{m})$

ETM Enhanced Thematic Mapper

$\boldsymbol{F} \quad$ Fetch length $(\mathrm{m})$

$\boldsymbol{F D D}, \boldsymbol{T} \boldsymbol{D} \boldsymbol{D}$ Freezing degree days, thawing degree days

$\boldsymbol{g} \quad$ Gravitational acceleration $\left(\mathrm{m} \mathrm{s}^{-2}\right)$

$\boldsymbol{i} \quad$ An integration point

IPY International Polar Year (2007-2008)

$\boldsymbol{I}_{\boldsymbol{v}} \quad$ Volumetric excess ice content (\%)

$\left.\operatorname{det} \mid \boldsymbol{J}_{j}\right] \quad$ Jacobian matrix determinant

$[\boldsymbol{K}],[\boldsymbol{M}] \quad$ Element characteristic matrix, element heat matrix

$\boldsymbol{L} \quad$ Latent heat required to thaw the water contained in a given volume of soil $\left(\mathrm{kJ} \mathrm{m}^{-3}\right)$

$<N>\quad$ Vector of interpolating function 
Number of items considered

N, E, S, W North, East, South, West

NSERC Natural Sciences and Engineering Research Council

OCF Old Crow Flats

$\boldsymbol{O}_{\boldsymbol{v}} \quad$ Volumetric content of organic material $\left(\mathrm{m}^{3} \mathrm{~m}^{-3}\right)$

$\boldsymbol{P} \quad$ Period (s)

$\boldsymbol{p} \quad$ Porosity $\left(\mathrm{m}^{3} \mathrm{~m}^{-3}\right)$

$\boldsymbol{Q} \quad$ Applied boundary heat flux $\left(\mathrm{W} \mathrm{m}^{-1}\right)$

$\{\boldsymbol{Q}\} \quad$ Element of applied flux vector

$\boldsymbol{S} \quad$ Designation for summation over the edge of an element

$\boldsymbol{S P} \quad$ Subsidence potential $(\mathrm{cm})$

Temperature $\left({ }^{\circ} \mathrm{C}\right)$

$\boldsymbol{T}_{\boldsymbol{g}, \boldsymbol{p s}, \boldsymbol{l b}} \quad$ Annual mean temperature measured at the depth of zero annual amplitude, the permafrost surface, the lake bottom $\left({ }^{\circ} \mathrm{C}\right)$

$\{\boldsymbol{T}\} \quad$ Vector of nodal temperatures

$\boldsymbol{t} \quad$ Time (s)

$\boldsymbol{t}_{\boldsymbol{t r}} \quad$ Time between submergence and the end of seasonnal frost penetration in the lake bottom (s)

$\boldsymbol{U} \quad$ Wind speed $\left(\mathrm{m} \mathrm{s}^{-1}\right)$

$\boldsymbol{u}_{\%} \quad$ The proportion of the soil pore water that is unfrozen $\left(\mathrm{m}^{3}\right.$ $\left.\mathrm{m}^{-3}\right)$

$\boldsymbol{V} \quad$ Volume $\left(\mathrm{m}^{3}\right)$

$\boldsymbol{V}_{\boldsymbol{c}, \boldsymbol{t}} \quad$ Volume of a frozen core sample, thawed core sample $\left(\mathrm{cm}^{3}\right)$

xxiv 
$\boldsymbol{V}_{\boldsymbol{s s}, \boldsymbol{s w}} \quad$ In a thawed core sample: volume of saturated sediment, volume of supernatant water $\left(\mathrm{cm}^{3}\right)$

VGFN Vuntut Gwitchin First Nation

$\boldsymbol{W} \quad$ Wave length $(\mathrm{m})$

$\boldsymbol{W}_{\boldsymbol{j}} \quad$ Weighting factor

$\boldsymbol{w}_{\boldsymbol{u}} \quad$ Gravimetric unfrozen water content $\left(\mathrm{g} \mathrm{g}^{-1}\right)$

$\boldsymbol{x}, \boldsymbol{y}, \boldsymbol{z} \quad$ Horizontal distance, height above the ground surface, depth below the ground surface (m)

$\boldsymbol{\theta}, \boldsymbol{\theta}_{\boldsymbol{u}} \quad$ Volumetric total water content, and unfrozen water content $\left(\mathrm{m}^{3} \mathrm{~m}^{-3}\right)$

$\lambda_{f, t} \quad$ Thermal conductivity of frozen ground and thawed ground ( $\mathrm{J}$ $\left.\mathrm{s}^{-1} \mathrm{~m}^{-10} \mathrm{C}^{-1}\right)$

$\boldsymbol{\lambda}_{\boldsymbol{i}, \boldsymbol{w}, \boldsymbol{o}, \boldsymbol{m}} \quad$ Thermal conductivity of ice, water, organic material, mineral soil $\left(\mathrm{J} \mathrm{s}^{-1} \mathrm{~m}^{-1}{ }^{\circ} \mathrm{C}^{-1}\right)$

$\left[\boldsymbol{\lambda}_{j}\right] \quad$ Element thermal conductivity matrix at integration point $j$

$\lambda_{x, y} \quad$ Horizontal and vertical thermal conductivity of the ground ( $\mathrm{J}$ $\left.\mathrm{s}^{-1} \mathrm{~m}^{-1 \circ} \mathrm{C}^{-1}\right)$

$\boldsymbol{\rho} \quad$ Soil dry density $\left(\mathrm{g} \mathrm{cm}^{-3}\right)$ 


\section{Part I}

\section{Introductory chapters}




\section{Chapter 1}

\section{Overview and objectives}

\subsection{Introduction}

This thesis is concerned with permafrost and thermokarst lakes in Old Crow Flats $(\mathrm{OCF})$, the principal interior basin of northern Yukon (Fig. 1.1). It investigates controls on ground temperature around and beneath lakes, and discusses the impacts of near-shore permafrost degradation patterns on talik geometry and drained basin topography.

Lakes and drained lake basins are ubiquitous in Arctic and sub-Arctic lowlands, with an areal coverage exceeding $40 \%$ in parts of northwestern Canada, Alaska, and Siberia (Grosse et al. 2013). These lake-ridden lowlands are underlain by permafrost, ground that remains at or below $0^{\circ} \mathrm{C}$ for two or more years, but the latent heat and the seasonal difference in modes of heat transfer in lake water disrupt geographical patterns of ground temperatures that are controlled by climate (Williams and Smith, 1989). For instance, lake-bottom temperatures remain at or above $0^{\circ} \mathrm{C}$ year-round where water depths exceed the maximum winter-ice thickness, causing underlying permafrost to degrade and a zone of thawed ground, or talik, to develop beneath the lakes.

Thawing of ice-rich permafrost may lead to settlement of the ground surface and formation of depressions where water tends to accumulate. Lakes that occupy such depressions are called thermokarst lakes (van Everdingen, 1998). Thermokarst lakes expand by permafrost degradation and may drain suddenly via fluvial tapping or truncation due to rapid coastal retreat, leaving distinct topographical and 

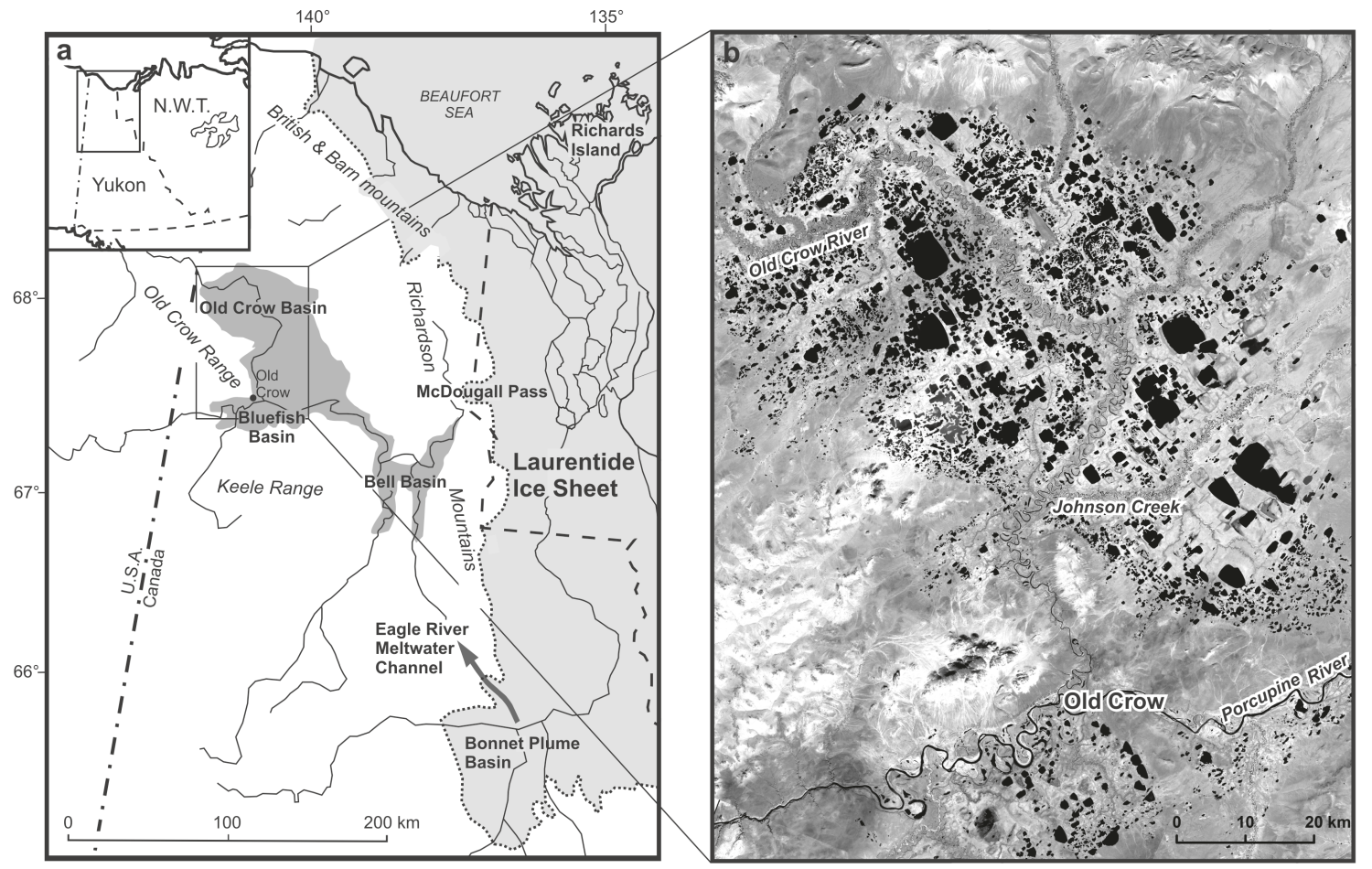

Figure 1.1: Location map of Old Crow Flats showing (a) northern Yukon with extent of Glacial Lake Old Crow in the Bell, Bluefish, and Old Crow basins. The approximate maximum limit of the Laurentide Ice Sheet is shown in light grey (after Rampton, 1988, Fig. 55; Zazula et al., 2004, Fig. 1; Kennedy and Froese, 2008, Fig. 2, Lauriol et al., 2009, Fig. 1) and (b) Landsat ETM orthoimage of Old Crow Flats and surrounding areas acquired on August 30th 2001. Waterbodies are in black (CDepartment of Natural Resources Canada. All rights reserved). 
sedimentary signatures in the surface deposits Aré, 1973, Hopkins and Kidd, 1988 , Mackay, 1992; Burn, 1992; Murton, 1996; Jorgenson and Shur, 2007).

Scientific interest in the interactions between thermokarst lakes, permafrost, and climate has increased over the last 15 years due to the important role of these lakes in the carbon cycle. Permafrost degradation around and under ponds and lakes results in the thawing of organic carbon previously stored in frozen ground. Decomposition of this carbon under anaerobic conditions in the lake bottom is linked to methane emissions from wetlands and constitutes a positive feedback to climatic warming (Walter et al., 2006, 2007; Zimov et al., 2006). On the other hand, enhanced lake productivity due to nutrient input from the thawed sediment, permafrost aggradation following catastrophic drainage, and peatland development in drained basins are associated with carbon sequestration, all of which provide negative feedbacks to climatic warming van Huissteden et al., 2011; Klein et al., 2013; Walter-Anthony et al., 2014). Changes in the balance of these processes can cause thermokarst lakes to shift from carbon sink to source Walter-Anthony et al. 2014). This is of particular concern in Arctic peatlands where soil organic carbon content is high and thermokarst lakes are most abundant Smith et al. 2007; Tarnocai et al., 2009).

Arctic peatlands affected by thermokarst lakes are seldom studied directly due to difficult field access and, as a result, there is relatively little data on permafrost conditions and degradation mechanisms around lakes and drained basins (e.g. Burn and Smith, 1990; Mackay, 1992, Burn, 2002, Lin et al., 2010, Arp et al., 2011). Investigations of lake expansion and drainage rates conducted by remote-sensing have revealed substantial differences between regions of Siberia, Alaska, and northern Canada which may be controlled by variations in local permafrost conditions and degradation rates (Smith et al., 2005; Riordan et al., 2006; Carroll et al., 2011; Jones et al., 2011; Chen et al., 2014; Karlsson et al., 2013, Macrae et al., 2014). Numerical models have also been used to investigate changes in permafrost 
conditions linked to thermokarst-lake development and drainage Smith, 1976; Burn and Smith, 1990; Pelletier, 2005; Lantz and Kokelj, 2008; West and Plug, 2008; Plug and West, 2009; Matell et al., 2013), but the lack of field data to adequately define boundary conditions, parameterize models, and evaluate simulations limits the development of effective predictive models of thermokarst lake evolution at local scale and landscape scales Ling and Zhang, 2004, van Huissteden et al., 2011). For instance, the links between mechanisms controlling permafrost degradation in shore banks and lake morphometry remain ambiguous and are frequently debated in the context of oriented thermokarst lakes Carson, 1968; Mackay, 1963; Harry and French, 1983; Côté and Burn, 2002, Pelletier, 2005, Hinkel, 2006). Permafrost degradation beneath the shallow, near-shore zone of expanding lakes and ponds is rarely considered in talik simulations (Zhou and Huang, 2004, West and Plug, 2008, Rowland et al., 2011; Matell et al., 2013) yet it is a key factor for methane emissions from thermokarst lakes (Walter et al., 2006, Kessler et al., 2012) and an important component of thermokarst lake development. The evolution of lake basins after drainage is also understudied and may be inadequately represented in the thermokarst lake cycle (Jorgenson and Shur, 2007), a conceptual model of thermokarst lake evolution that was developed in and applied to several Arctic lowlands of northern Alaska (Britton, 1967; Billings and Peterson, 1980; Jorgenson and Shur, 2007) but is seldom applied to Canadian thermokarst landscapes.

This thesis examines links between permafrost conditions, talik geometry, and drained basin topography in OCF, an Arctic peatland with thousands of thermokarst lakes.

\subsection{Old Crow Flats}

OCF is a $5600 \mathrm{~km}^{2}$ Arctic lowland surrounded by mountains. It is located at the eastern edge of Beringia. The area was not glaciated during the Wisconsinan Stage 
but was submerged beneath a $13,000 \mathrm{~km}^{2}$ glacial lake, which drained catastrophically 15,000 years ago (Fig. 1.17) (Zazula et al., 2004). Today the glaciolacustrine sediment is blanketed with peat and over 2500 lakes cover approximately $35 \%$ of the Flats (Fig. 1.1b) Yukon Ecoregions Working Group, 2004). The area is underlain by continuous permafrost, and river-bank exposures suggest that the glaciolacustrine deposits are the sole stratigraphic layer with excess ground ice in the upper $40 \mathrm{~m}$ of deposits underlying OCF (Matthews et al. 1990). Little information is available on ground thermal conditions in OCF but, in the community of Old Crow, permafrost was $63 \mathrm{~m}$ thick and the ground temperature at $15 \mathrm{~m}$ depth, when measured during geotechnical investigations in the 1980s, was $-4^{\circ} \mathrm{C}($ EBA Engineering Consultants Ltd, 1982$)$. Mean annual air temperature at Old Crow is $-9.0^{\circ} \mathrm{C}$ (Environment Canada data are available at http://climate.weather.gc.ca/index_e.html, accessed on October 26th, 2014), and the open water season extends from June to October.

The lakes of Old Crow Flats lack littoral shelves, and are generally flat-bottomed with an average depth of 1 to $1.5 \mathrm{~m}$ and a maximum depth of $4 \mathrm{~m}$ Gray and Alt, 2001). Some of these lakes may be remnants of the glacial lake (Fig. 1.17) while others likely developed by thermokarst processes during the early Holocene thermal optimum (Ovenden, 1985; Mackay, 1992; Burn, 1997). In parts of the Flats, the lakes have rectilinear shorelines and are oriented either NE-SW or NW-SE. Drained basins are abundant in the Flats and frequently have incised outlets, suggesting that catastrophic drainage is part of the natural evolution of the lakes. On remotely-sensed images of OCF the internal topography of many drained basins appears characterized by a wet, depressed margin and a higher, better drained centre, similar to drained-lake basins on the Beaufort Coastal Plain (Jorgenson and Shur, 2007). Dates from basal peat samples collected in OCF suggest that much of the area has been reworked by thermokarst processes over the last 10,000 years (Ovenden, 1985). 
OCF is recognized as a wetland of international significance through the Ramsar convention (The Secretariat of the Convention on Wetlands, 2014) and is a key part of the traditional territory of the Vuntut Gwitchin First Nation, who expressed concern that effects of climatic warming on the landscape may threaten the traditional activities and food security of local residents. Despite the multi-layered significance of OCF, remarkably little is known of permafrost conditions and thermokarst processes in the area. This thesis helps to fill this void by investigating the configuration of permafrost conditions near lakes in OCF. Further, it builds on this location-specific investigation to consider the immanent principles which underlie this permafrost configuration, and yields an improved understanding of interactions between thermokarst lakes and permafrost that may be transferable to other Arctic lowlands.

\section{$1.3 \quad$ Research objectives}

The examination of interactions between permafrost and thermokarst lakes in this thesis is organized around three primary objectives.

The first objective is to examine spatial variation in ground temperatures within the forest-tundra ecotone near Old Crow. This is achieved by collecting data on ground temperatures, snow depths, and vegetation structure in taiga, tall shrub $(>0.5 \mathrm{~m})$ and low shrub $(<0.5 \mathrm{~m})$ patches in distinct ecological contexts. The working hypothesis for this part of the thesis is that, within the patchy vegetation assemblages of the forest-tundra ecotone in OCF, ground temperatures decline with decreasing height of the vegetation, creating a heterogeneous ground temperature field.

The second objective of this thesis is to investigate talik development near thermokarst lake shores. This is achieved by describing talik geometry near shorelines with varying recession rates, bathymetries, and lake-bottom thermal 
regimes; by comparing field observations with approaches used to predict permafrost degradation beneath lakes of the Mackenzie Delta area and central Yukon; and by investigating inconsistencies using a numerical model of ground freezing and thawing.

The third objective of this thesis is to investigate the genesis of the topography of drained basins and propose a landform development model adapted to conditions of OCF. This is achieved through a detailed examination of relations between elevation, peat thickness, excess-ice content, ice-wedge distribution, and sediment stratigraphy in three representative drained lake basins in a tundra area of OCF to determine the main controls on topography within the basins. The working hypothesis for this part of the thesis is that the development of depressed margins and raised centres is not dependent on a frost susceptibility gradient along the lake bottom. Instead, I hypothesize that the raised centres are a product of sedimentation in the lake during subsidence of the lake bottom due to talik development and subsequent refreezing of the deposited sediment and talik following lake drainage.

\subsection{Thesis structure}

Three primary research manuscripts, addressing the first, second, and third objectives of this research, constitute the core of this thesis and are presented in chapters 4 to 6 . Chapter 2 is a broad literature review that situates these manuscripts in the context of previous research. This chapter is divided in two parts. Sections 2.1 to 2.4 provide a general introduction to Arctic lowlands and thermokarst lakes, and Section 2.5 introduces the study area. Chapter 3 presents an overview of the body of methods used in the thesis and the assumptions and techniques that link the chapters together. The specific methods used are described

in detail in the integrated chapters and are not discussed in this section to minimize 
repetition. Following the integrated manuscripts, Chapter 7 summarizes key findings, discusses implications and limitations, and suggests directions for future research. 


\section{Chapter 2}

\section{Background}

\section{$2.1 \quad$ Introduction}

This thesis investigates the interactions between permafrost and thermokarst lakes in Old Crow Flats (OCF). Such an investigation requires prior understanding of (1) permafrost and its thermal regime; (2) the development of ground ice; (3) the life cycle of thermokarst lakes; and (4) the physiography of OCF. This chapter reviews literature pertaining to these four themes, focussing on material that is specifically relevant to $\mathrm{OCF}$ and the research presented in this thesis.

\subsection{Permafrost}

\subsubsection{Definition and significance}

Permafrost, earth materials that remain at or below $0^{\circ} \mathrm{C}$ for two or more years van Everdingen, 1998), underlies approximately one fifth of the exposed landmass in the northern hemisphere (Fig. 2.1). It may be composed of bedrock, unconsolidated mineral soil, organic material, or ice, and often includes air and unfrozen water in the pore space. The proportions and characteristics of these constituting materials are linked to the significance of permafrost thaw. For instance, where permafrost contains unconsolidated mineral soil and pure ice, thawing may lead to a loss of ground volume, surface deformation and instability, and the development of a pitted relief called thermokarst (Nelson et al., 2001; Burn, 2013). Where permafrost contains substantial organic material, thawing may lead to the release of carbon dioxide and methane and contribute positive feedback to climatic warming (Schaefer 


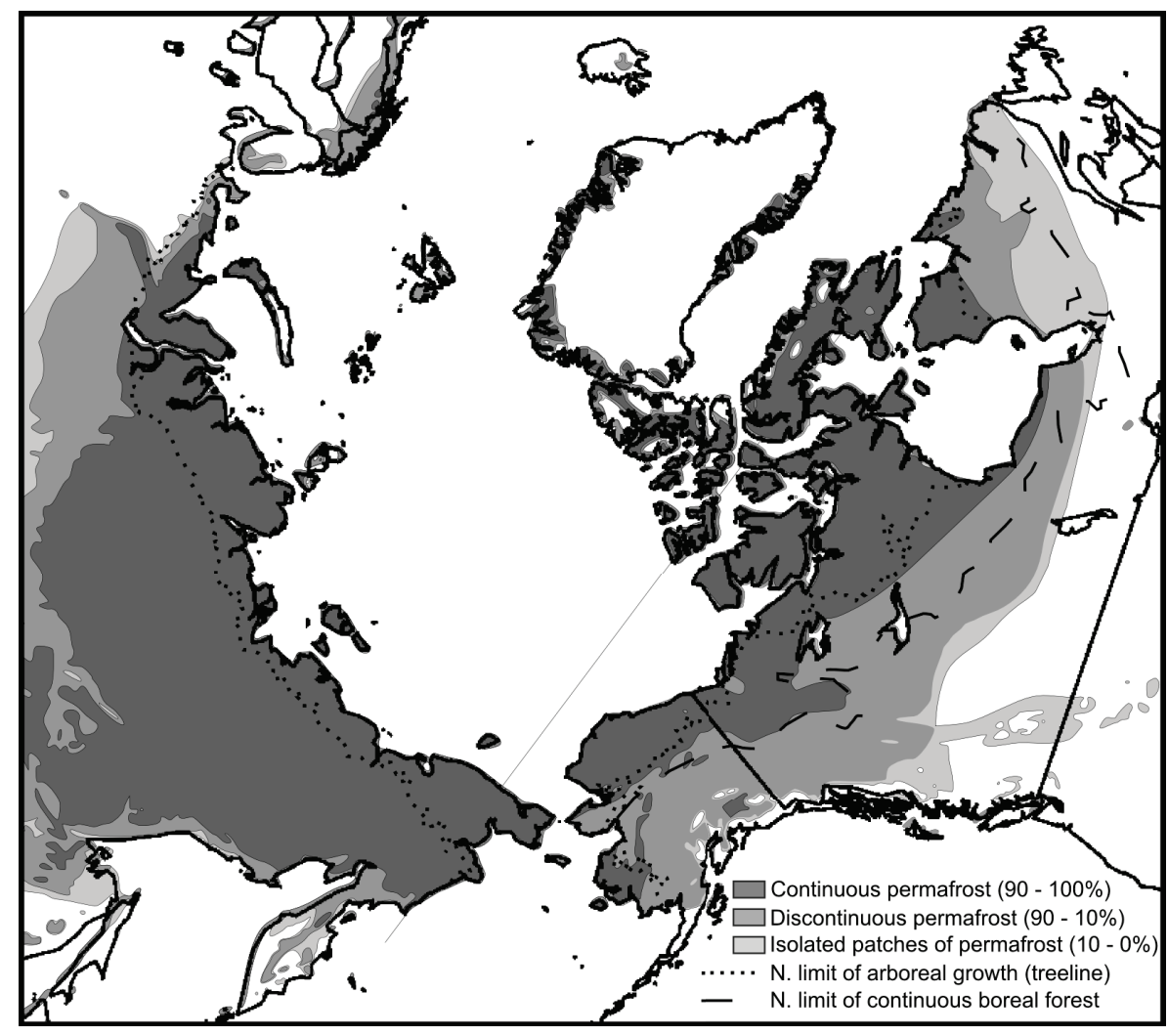

Figure 2.1: Permafrost distribution and northern limit of arboreal growth in the Northern Hemisphere (Brown et al., 1997), modified from Ahlenius (2007). Treeline is from the circumpolar Arctic vegetation map (CAVM Team, 2003), and the northern limit of continuous boreal forest, shown for North America only, is from Payette et al. (2001). 
et al. 2014). The impact of ground ice on surface stability and the potential amplification of anthropogenic warming due to carbon emissions from thawing permafrost are two important drivers of current permafrost research. The research presented in this thesis, focussing on permafrost dynamics in a thermokarst-affected peatland, contributes to these two general streams of permafrost research.

\subsubsection{Thermal properties}

The relations between conditions at the ground surface and the permafrost thermal regime are mediated by the ground's thermal properties, which are determined by the proportion, structure, and thermal characteristics of the ground's constituents (Table 2.1) Andersland and Ladanyi, 2003). In particular, the contrast between the properties of water and ice dominates the thermal characteristics of soils below $0^{\circ} \mathrm{C}$. The thermal conductivity of water $\left(\lambda_{w}, \mathrm{~J} \mathrm{~s}^{-1} \mathrm{~m}^{-10} \mathrm{C}^{-1}\right)$, which is a measure of the amount of heat per unit area that flows along a temperature gradient of $1^{\circ} \mathrm{C} \mathrm{m}^{-1}$ in a second, increases four-fold when it freezes, and its volumetric heat capacity $\left(C_{w}, \mathrm{~J}\right.$ $\mathrm{m}^{-3 \circ} \mathrm{C}^{-1}$ ), which is the amount of heat required to raise the temperature of $1 \mathrm{~m}^{3}$ of water by $1^{\circ} \mathrm{C}$, decreases by more than one half upon freezing Williams and Smith, 1989).

Despite contrasting thermal properties of water and ice, the transition between the thermal properties of frozen and thawed ground is not abrupt at $0^{\circ} \mathrm{C}$, but rather occurs over a range of temperatures nearing $0^{\circ} \mathrm{C}$, as the volumetric unfrozen water content $\left(\theta_{u}, \mathrm{~m}^{3} \mathrm{~m}^{-3}\right)$ of the ground increases progressively. This depression of the melting point of water is due to adsorption, which binds layers of water molecules to the surface of the soil particles, and to the effect of small pore diameters on the curvature of the ice-water interface. These phenomena reduce the amount of water available for freezing at or below $0^{\circ} \mathrm{C}$. Below $-1.5^{\circ} \mathrm{C}$, the unfrozen water is almost exclusively adsorbed and, between -1.5 and $0^{\circ} \mathrm{C}$, the curvature of the ice-water interface in the pores plays an important role (Williams and Smith, 1989). The 


\begin{tabular}{lccc}
\hline Material & $\begin{array}{c}\text { Density } \\
\left(\mathrm{kg} \mathrm{m}^{-3}\right)\end{array}$ & $\begin{array}{c}\text { Heat capacity } \\
\left(\mathrm{kJ} \mathrm{kg}^{-1}{ }^{\circ} \mathrm{C}^{-1}\right)\end{array}$ & $\begin{array}{c}\text { Thermal } \\
\text { conductivity } \\
\left(\mathrm{W} \mathrm{m}^{-1} \mathrm{C}^{-1}\right)\end{array}$ \\
\hline Air & 1.2 & 1.01 & 0.025 \\
Water $\left(0^{\circ} \mathrm{C}\right)$ & 100 & 4.18 & 0.56 \\
Ice $\left(0^{\circ} \mathrm{C}\right)$ & 917 & 2.10 & 2.24 \\
Organic matter & 1300 & 1.92 & 0.25 \\
Clay minerals & 2650 & 0.90 & 2.92 \\
Quartz & 2260 & 0.80 & 8.80 \\
\hline
\end{tabular}

Table 2.1: Thermal properties of typical soil constituents (Williams and Smith 1989, Table 4.1; Andersland and Ladanyi 2003, Table 2.11) 
total amount of water held in an unfrozen state at a given temperature varies with soil particle-size distribution and specific surface area. Fig. 2.2 shows the amounts of unfrozen water in soils of different textures at different temperatures. Current practice is to estimate gravimetric unfrozen water content $\left(w_{u}, \mathrm{~g} \mathrm{~g}^{-1}\right)$ from empirical equations developed by Tice et al. (1976) of the form :

$$
w_{u}=\alpha|T|^{\beta}
$$

where $w_{u}$ is determined for a given temperature $\left(\mathrm{T},{ }^{\circ} \mathrm{C}\right)$ expressed as an absolute value, using two empirically derived soil characteristic parameters: $\alpha$ and $\beta$ Burn, 1998; Romanovsky and Osterkamp, 2000; Andersland and Ladanyi, 2003). The volumetric unfrozen water content $\left(\theta_{u}, \mathrm{~m}^{3} \mathrm{~m}^{-3}\right)$ is obtained by multiplying $w_{u}$ by the soil dry density $\left(\rho, \mathrm{g} \mathrm{cm}^{-3}\right)$ (Smith and Tice, 1988), and the proportion of the pore water that is unfrozen $\left(u_{\%}\right)$ is obtained by dividing $\theta_{u}$ by the total volume of pore water.

As a result of this progressive change in unfrozen water content near $0^{\circ} \mathrm{C}$, the thermal properties of the ground also follow a progressive transition between the values for frozen and thawed soil. The thermal conductivity of frozen saturated soil $\left(\lambda_{f}\right)$, for example, can be calculated using a geometric average, e.g., from Johansen (1977):

$$
\lambda_{f}=\left(\lambda_{w}^{u_{\%} p}\right)\left(\lambda_{i}^{I_{v}+\left(1-u_{\%}\right) p}\right)\left(\lambda_{o}^{V_{o}}\right)\left(\lambda_{m}^{V_{m}}\right)
$$

where $\lambda_{i}, \lambda_{w}, \lambda_{o}$, and $\lambda_{m}$ are the thermal conductivities of ice, water, organic material, and mineral soil, respectively. $V_{o}$ and $V_{m}$ are the volumetric fractions of organic and mineral materials. The porosity, $p$, is the total pore space divided by the volume of the frozen core, and thus $\left(1-\theta_{u}\right) p$ represents the volumetric fraction of pore ice. $I_{v}$ represents the volumetric fraction of ice that is in excess of pore space, the volumetric excess ice content. Similarly, the volumetric heat capacity of saturated frozen soil $\left(C_{f}\right)$ for given temperatures along the unfrozen water content curve can be determined based on a weighed arithmetic average of the form 


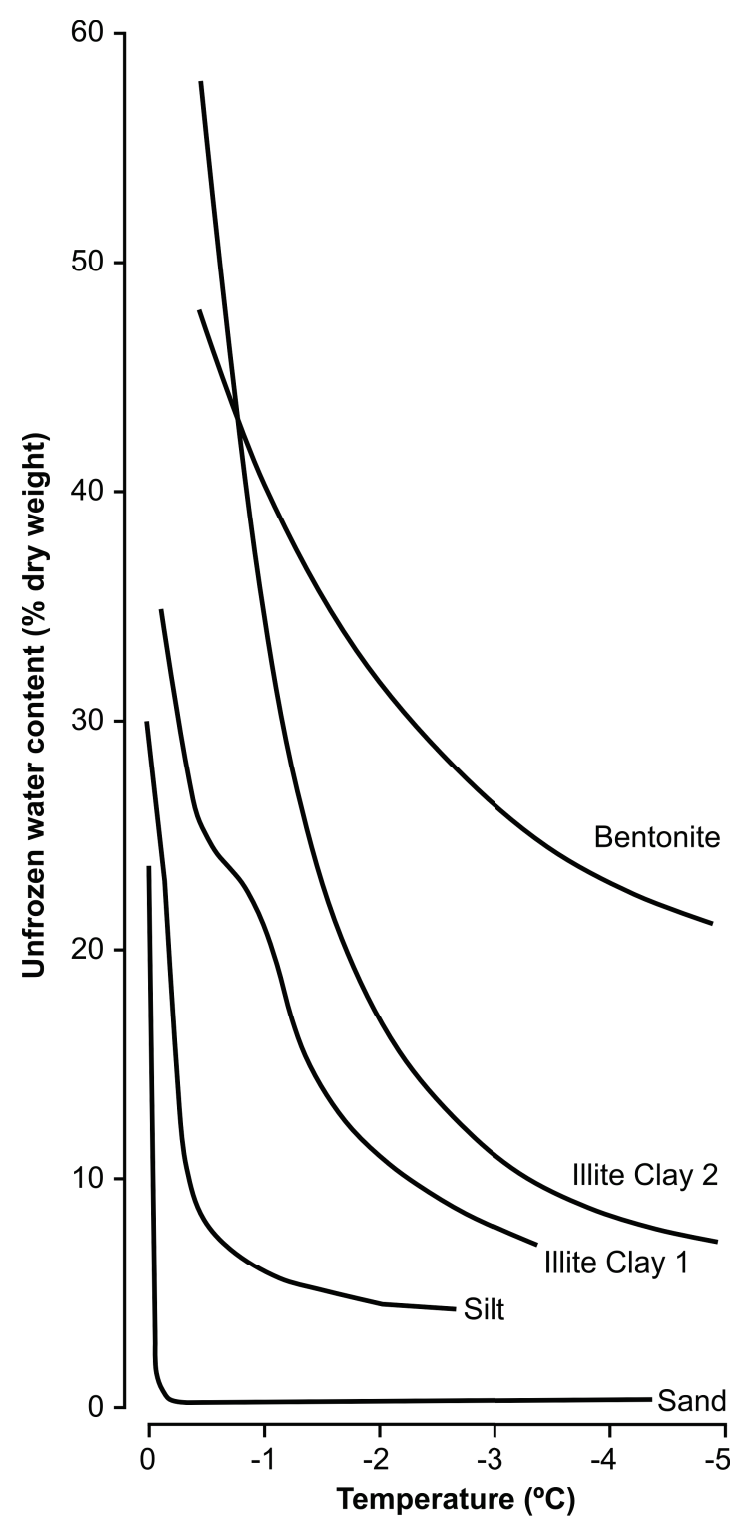

Figure 2.2: Gravimetric unfrozen water content of various soils at temperatures lower than $0^{\circ} \mathrm{C}$, modified from Burt and Williams (1976, Fig.1). 
(Williams and Smith, 1989):

$$
C_{f}=\left[C_{m} V_{m}+C_{o} V_{o}+C_{i}\left(I_{v}+\left(1-u_{\%}\right)\right) p+C_{w} p u_{\%}\right]
$$

However, the latent heat required to progressively increase the unfrozen water content as the ground warms will result in an apparent heat capacity different from that obtained from Equation 2.3 (Andersland and Ladanyi, 2003). Indeed, the latent heat required to melt one cubic metre of ice, $\mathrm{L}=3.06 \times 10^{5} \mathrm{~kJ}$, would be sufficient to increase the temperature of such a volume of ice by $160^{\circ} \mathrm{C}$ if phase change did not occur (Table 2.1. For purposes of thermal modelling, this apparent heat capacity of frozen ground $\left(C_{a}, \mathrm{~J} \mathrm{~m}^{-3}{ }^{\circ} \mathrm{C}^{-1}\right)$ may be used to account for latent heat, by adding the heat that is absorbed or released over a given temperature interval to the heat capacity (Williams and Smith, 1989):

$$
C_{a}=C+L\left(\frac{d \theta_{u}}{d T}\right)
$$

\subsubsection{Thermal regime}

Over the course of a year, temperature fluctuates in the upper layers of permafrost as a result of variations in air temperature and surface conditions (Burn, 2013). The amplitude of this fluctuation is dampened with depth at a rate controlled by the thermal diffusivity of the ground, $\frac{\lambda}{C}$ (Fig. 2.3) Carslaw and Jaeger, 1995). The depth of zero annual amplitude, where the difference between the annual maximum and minimum temperatures is $\leq 0.1^{\circ} \mathrm{C}$, typically ranges between 10 and $25 \mathrm{~m}$ below the ground surface. It is deepest in bedrock and sand, where $\frac{\lambda}{C}$ is high, and shallowest in peatlands, where $\frac{\lambda}{C}$ is low due to high moisture contents in the peat. Temperature at the depth of zero annual amplitude is the annual mean ground temperature $\left(T_{g},{ }^{\circ} \mathrm{C}\right)$. An instantaneous measurement of $T_{g}$ is considered a robust approximation of mean ground temperature because it does not fluctuate with 


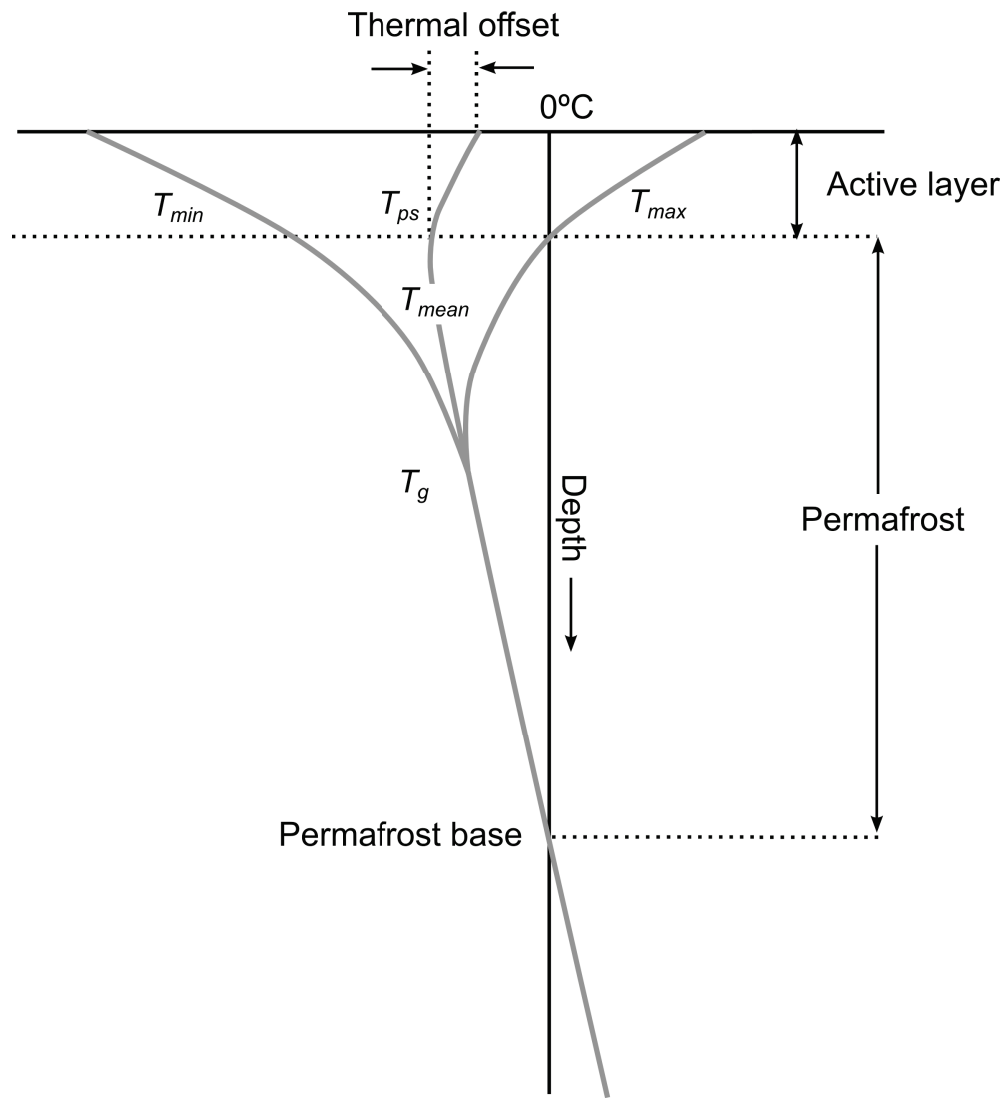

Figure 2.3: The thermal regime of permafrost, modified from Burn (2013, Fig. 1). 
short-term variations in surface conditions but it responds to long-term trends Berry, 1981; Williams and Smith, 1989). Annual mean temperature near the

permafrost surface, $T_{p s}$, responds more readily to changes in surface conditions and varies from year to year. However $T_{g}$ is similar to $T_{p s}$ averaged over several years, and both are controlled by interactions between the lower atmosphere, the vegetation and snow cover, and the thermal properties of the active layer, the ground located immediately above permafrost that freezes and thaws seasonally.

\subsubsection{Active-layer thermal regime}

Moisture in the active layer causes pronounced seasonal changes in ground thermal properties that can enhance the release of heat from the ground during winter and hinder the conduction of heat into the ground during summer. This causes $T_{p s}$ to be lower than temperature at the ground surface, $T_{s}$, and results in an inflection in the near-surface temperature profile (Burn and Smith, 1988) (Fig. 2.3). The difference between $T_{p s}$ and $T_{s}$, called the thermal offset, occurs where active-layer materials include water. Thermal offsets over $1.5^{\circ} \mathrm{C}$ have been observed in peat, which tends to be dry during summer and saturated before freezing (Burn, 1988). Where fine grained materials constitute the active layer, the thermal offset may be attenuated by the effect of unfrozen water on $\lambda$ and $C_{a}$ (Romanovsky and Osterkamp, 2000).

The freezing and thawing of the active layer also causes the release and absorption of large quantities of latent heat, which dominate the heat flux near the ground surface. During freeze-back in autumn, the surface thermal signal cannot propagate to the underlying permafrost and temperatures in the lower portions of the active layer remain isothermal slightly below $0^{\circ} \mathrm{C}$ (Outcalt and Hinkel, 1996). This persistence of a nearly constant temperature, very close to the freezing point, due to the dissipation of latent heat during freezing of the ground is termed the zero curtain (van Everdingen, 1998). Cooling of the ground surface, active layer, and top of permafrost is inhibited during this period. Winter ground temperatures may 
appear to be relatively high in areas with increased soil moisture, particularly if the snow cover prevents latent heat from escaping, resulting in reduced rates of frost penetration and a prolonged zero curtain (Karunaratne and Burn, 2003; Stieglitz et al., 2003, Morse et al., 2012). Following the zero curtain, ground temperature near the permafrost surface begins to decrease, indicating that sensible heat is removed from the ground. Release of latent heat may continue after the end of the zero curtain due to the unfrozen water content of the active layer and near-surface permafrost, inhibiting rapid ground cooling Romanovsky and Osterkamp, 2000; Kokelj et al. 2014). This effect is also enhanced if snow provides insulation at the ground surface.

\subsubsection{Snow cover}

Variations in winter ground temperature resulting from interaction of active layer moisture and snow-pack thickness account for most of the temporal and spatial variability in $T_{p s}$ at the landscape scale $(5-100 \mathrm{~km})$ Mackay and MacKay, 1974; Stieglitz et al., 2003; Karunaratne, 2011; Morse et al., 2012; Palmer et al., 2012).

The snow cover also reduces the amplitude of the ground temperature variations by protecting the ground from abrupt decreases in air temperature during winter, whereas during summer the ground is not similarly insulated from abrupt temperature increases (Goodrich, 1982).

The ground thermal regime is most sensitive to increases in snow thickness when the snow cover is thin and, as a consequence, increases in snow depth beyond $50 \mathrm{~cm}$ have little further effect Nicholson et al., 1973, Smith, 1976, Iijima et al., 2010). In the boreal forest, snow depth is controlled by snow supply and interception by the forest canopy (Hedstrom and Pomeroy, 1998; Kanigan et al., 2009).

In the tundra, redistribution of snow by wind leads to the development of thinner and denser snow covers with poor insulating properties. Local snow-pack thickness is controlled by the snow-holding capacity of the local vegetation and by 
snow availability for redistribution in the surrounding landscape Pomeroy et al., 1995). Whereas relations between vegetation structure, snow-pack development, and ground temperatures are well documented in the boreal forest and in the tundra, they have been scarcely studied in the forest-tundra transition where the vegetation cover is a heterogenous assemblage of close-canopy forest, sparse taiga, tall shrubs, and low shrubs with sedges (Timoney et al., 1992a; Kershaw and McCulloch, 2007).

\subsubsection{Thermal condition in the forest-tundra ecotone}

Payette et al. (2001) define the forest-tundra ecotone as the transition zone that extends between the northern limit of continuous forest and the northernmost position of arboreal growth. The typical northward progression of structural vegetation classes through the forest-tundra transition includes taiga, tall shrub tundra (40-400 cm tall), erect dwarf shrub tundra (10-40 cm tall), and dwarf shrub tundra (less than $10 \mathrm{~cm}$ tall) (Lantz et al., 2010). Transition between each of these classes is often gradual and patchy and information on thermal conditions within this transition is scarce, even though, in aggregate, the transition is thermally more important than any other in the landscape of permafrost regions.

The presence of trees affects the surface energy balance by decreasing the surface albedo and thereby increasing net radiation during the snow season. Winter albedos vary with tree density and exposure of snow cover, assuming values of $70-80 \%$ in tundra, $60-67 \%$ in forest-tundra, and 50-55\% in open crown forest Hare and Ritchie, 1972). This difference in albedo can cause net radiation to be four to five times larger over forest than tundra during winter and allows rapid warming in spring where the tree cover is dense (Lafleur et al. 1993). As a result of this, the thaw season is approximately 10 days shorter at the northern limit of arboreal growth than at the northern limit of the boreal forest (Hare and Ritchie, 1972).

The thickness of the snow cover generally decreases northward across treeline (Palmer et al. 2012). In the forest tundra transition N of Great Slave Lake, 
Timoney et al. (1992a) note that snow depth is uniform at closed and open-canopy forest sites, whereas it is variable in tundra dominated landscapes, where snow is redistributed by wind and accumulates in pockets sheltered by topography or vegetation structure. Near Churchill, MB, Kershaw and McCulloch (2007) report deep snow drifts near the edges of a tree island surrounded by tundra.

Near the treeline transition, $T_{g}$ is commonly between -2 and $-5^{\circ} \mathrm{C}$ in the continuous permafrost zone and often near $0^{\circ} \mathrm{C}$ in the zones of discontinuous permafrost Romanovsky et al. 2010a). Information on the spatial variability of ground temperatures within the forest-tundra ecotone is limited but, in the Mackenzie Delta, Palmer et al. (2012) found that the northward decrease in snow-cover thickness results in a negative latitudinal gradient in ground temperature across the treeline transition. The research presented in this thesis investigates permafrost configuration in the forest-tundra ecotone of northern Yukon. OCF is underlain by continuous permafrost but little is known of permafrost conditions, nor snow conditions, in the area. The first part of this study, presented in Chapter 4, is a general assessment of $T_{g}$ in the OCF area, and an investigation of relations between vegetation height, snow-pack development, and $T_{p s}$ in parts of OCF where the vegetation cover is dominated by sparse taiga or by low shrub tundra. This assessment informed the investigations of permafrost degradation beneath shallow water and permafrost aggradation in drained basins presented in chapters 5 and 6 .

\subsection{Ground ice}

\subsubsection{Definitions and significance}

Ground ice refers to all types of ice contained in freezing and frozen ground, and may take the form of lenses, wedges, veins, sheets, and individual crystals or coatings on mineral and organic particles van Everdingen, 1998). Ground moisture may freeze in place in the soil matrix to become pore ice, it may be drawn towards 
the freezing front by thermal and pressure gradients to form segregated ice, it may move under the effects of gravity to accumulate in thermal contraction cracks and form ice wedges, or it may be forced into the ground by pressure to form bodies of intrusive ice (Mackay, 1972). Pore ice is ubiquitous but segregated and wedge ice contribute the largest volume of excess ice in near-surface permafrost Pollard and French, 1980).

Permafrost that contains excess ice contains more water by volume in the form of ground ice than the pore space of unfrozen ground (van Everdingen, 1998). Such permafrost is described as ice rich. If ice-rich permafrost thaws, the portion of the water volume exceeding pore space will be released from the soil matrix and either flow away, evaporate, or accumulate in a depression at the surface (Burn, 2013). The ground will settle under its own weight until it attains a consolidated state where total pore volume is in equilibrium with stress due to gravity Pollard and French, 1980). The settlement or subsidence potential (SP) of ice-rich permafrost is equal to the portion of its volume which constitutes excess ice. If excess ice constitutes $14 \%$ of the ground volume in the upper $10 \mathrm{~m}$ of permafrost, as is the case on Richards Island in the Mackenzie Delta, thawing of this ground layer may lead to an average subsidence of $1.4 \mathrm{~m}$ (Pollard and French, 1980). The subsidence potential of ice-rich permafrost is of particular significance as it may threaten surface stability and cause the development of thermokarst topography upon permafrost thaw.

Frost-susceptible soils are soils that are likely to become ice-rich upon freezing due to the development of segregated ice lenses. The upward movement of the ground surface due to this increase in volume, termed frost-heaving, is not uniform as it reflects variations in soil texture, heat removal rate, and groundwater supply over short distances. The development of various types of ground ice is responsible for the formation of numerous periglacial landforms, such as polygon networks Lachenbruch, 1962, Mackay, 1992, palsas (Pissart, 2002), and pingos Mackay, 1973). The following discussion of ground ice will focus on pore ice, aggradational 
ice, and wedge ice, which are most relevant to conditions in OCF.

\subsubsection{Pore ice}

During penetration of the freezing front, water can freeze in situ to form pore ice and cement soil particles together, similar to the cement of a sandstone Mackay, 1972). This structureless form of ground ice can expand pore space upon freezing in a saturated soil, but it is generally not counted as excess ice Mackay, 1972, French and Shur, 2010).

\subsubsection{Segregated ice}

Segregated ice forms as pore water is drawn towards lower temperatures along a suction gradient that is driven by the temperature gradient in a freezing soil. It may develop as water migrates through the thawed ground towards the freezing front, but the unfrozen water content of fine grained soils allows water flow and ice segregation to continue along the temperature gradient behind the freezing front Burt and Williams, 1976, Smith, 1985). The permeability of frozen soil is lower than that of unfrozen soil and decreases with temperature as $\theta_{u}$ decreases, but the relatively low permeability is offset in part by the subtantial suction gradients that

are induced by temperature gradients in frozen ground. For instance, Smith 1985) observed substantial moisture migration at temperatures as low as $-2.4^{\circ} \mathrm{C}$ in a silt-clay active layer, and noted that slightly over one half of the measured heave occurred in soil that was colder than $-0.3^{\circ} \mathrm{C}$. Continued heaving of the ground surface associated with ice segregation beyond the freezing front in aggrading permafrost can create large heaving pressures and significant ground expansion and surface deformation (Miller, 1972; O'Neill and Miller, 1985).

Frost heave tends to be greatest in silty soils and absent in coarse sand and gravel, which expel excess water volume upon freezing (Mackay, 1972). Silts can retain unfrozen water by adsorption and capillarity (Fig.2.2), and have a high 
hydraulic conductivity, two key conditions facilitating ice segregation Konrad, 1999). Ice segregation may also occur in clays but their low hydraulic conductivity impedes the flow of water towards the freezing front. Ice segregation is also most effective in wet soils, and the largest ice lenses tend to develop where silts and clays are adjacent to sandy sediment, as the latter can act as a source of water. Such conditions have led to the development of massive segregated icy bodies, sometimes over $30 \mathrm{~m}$ in thickness, along the western Arctic coast of Canada (Mackay, 1971). Abrupt cooling of the ground surface and rapid frost penetration in the sediment are associated with the development of smaller ice lenses, unless sufficient water is available at the freezing front to ensure that all extracted heat is latent heat, thus causing the freezing front progression to stagnate while large lenses develop $O^{\prime} N e i l l$ and Miller, 1985).

\subsubsection{Aggradational ice}

In unconsolidated sedimentary deposits, an ice-rich zone typically occurs near the top of permafrost, the upper part of which may thaw in some years due to interannual variability in active-layer depth Mackay, 1972, Burn, 1988; Shur et al., 2005; O'Neill and Burn, 2012). Ice lenses are common in this transition zone, as temperature-controlled suction gradients draw water downward through the thawing active layer during summer but during winter, when thermal gradients favour water movement in the opposite direction, water migration is impeded by the low hydraulic conductivity associated with winter temperatures. This results in a water imbalance which contributes to the development of ice lenses in the lower parts of the active layer and in the top of permafrost Burn, 1988; Cheng, 1983). At the Illisarvik experimentally drained lake site, O'Neill and Burn (2012) observed ice enrichment of the top of permafrost to a depth of $60 \mathrm{~cm}$ beneath the permafrost table in 2010, 32 years after permafrost began to aggrade in the drained basin. Surface wetness was the main control on ice-enrichment rate. 
This process of ice-enrichment of the near-surface permafrost may be enhanced by ice aggradation if a rise in the permafrost table results in the incorporation of ice bodies formed near the base of the frozen active layer, such as segregated lenses or bodies of intrusive ice Mackay, 1972, Morse and Burn, 2013). Upward aggradation of permafrost into the active-layer may occur for a variety of reasons, including surface accretion due to deltaic, alluvial, or colluvial sedimentation, climatic cooling, or the development of an organic layer which changes the thermal regime near the ground surface.

\subsubsection{Ice wedges}

Ice wedges are massive bodies dominantly composed of foliated ice which form through the repeated infiltration and freezing of snowmelt in thermal contraction cracks (Mackay, 1974). Ice-wedges are the most widely distributed type of massive ground ice, and are found beneath more than 2 million square kilometres of tundra and boreal forest in the northern hemisphere (Mackay, 1972). Wedge-ice volumes up to $63 \%$ have been estimated in the near-surface permafrost of Yedoma deposits, where very large ice wedges developed syngenetically with loess deposition Ulrich et al., 2014).

Thermal contraction cracks develop when the stress caused by the thermal contraction of the ground during cooling exceeds the tensile strength of the ground for that range of temperatures (Lachenbruch, 1963). Organic deposits are more susceptible to thermal contraction cracking than fine-grained mineral soils, because frozen peat has a high volumetric water content and the thermal contraction of ice is 3-5 times greater than for mineral substrate for a given temperature change Lachenbruch, 1963; Kokelj et al., 2014). Thermal contraction cracking is typically associated with a rapid drop in air temperature, but the insulating properties of the snow cover may prevent ice wedges from cracking Lachenbruch, 1962, Mackay, 1992; Allard and Kasper, 1998). In the Mackenzie Delta area, Kokelj et al. (2014) 
found that the frequency of thermal contraction cracking, the size of ice wedges, and the density of polygon networks increased northward as snow depth decreased across treeline.

Ice wedges are typically interconnected in a network forming a polygonal pattern at the surface. Polygons usually have 4 to 7 sides and intersections are often orthogonal (Fig. 2.4). When the tensile stress is approximately isotropic, cracking is controlled by zones of weakness in the ground and polygons appear randomly distributed and oriented across the landscape. When the tensile stress is anisotropic due, for example, to the warming effect of a water body, cracks propagate perpendicular to the direction of maximum tension resulting in orthogonal polygons arranged perpendicular to the edge of the water body (Fig. 2.4). The topography of ice-wedge polygons may evolve over time and Mackay (2000) proposed a simple classification of the stages of polygon development based on their topography (Fig. $2.5)$.

Incipient polygons develop in areas with newly exposed mineral soil, such as in the bottoms of recently drained lakes, and may become low-centred polygons as the growth of wedge-ice causes ridges to develop on either sides of the ice-wedge troughs. Peat accumulation and continued deformation of the polygons from the growth of wedge ice causes the polygon centre to rise to an intermediate stage (Fig. 2.5). Lowering of the water level in the ice wedge troughs can lead to the development of high-centred polygons, or if the decrease in water level is abrupt and the polygon centre is ice rich, walled polygons may develop (Fig. 2.5). The most common cause of walled polygon development is catastrophic lake drainage (Mackay, 2000).

\subsubsection{Ground ice in glaciolacustrine environments}

Glaciolacustrine deposits of clay and silt typically provide a wet environment conducive to the development of high segregated ice contents. Cryostructures may be characterized by ice layers a few centimetres or several decimetres thick, resulting 

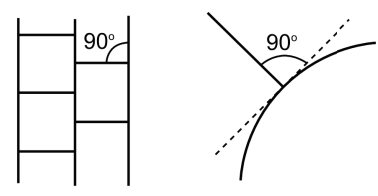

Orthogonal

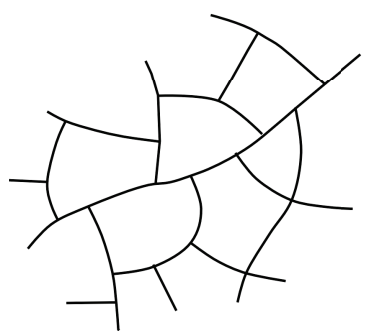

Random orthogonal

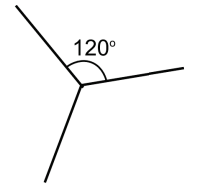

Hexagonal

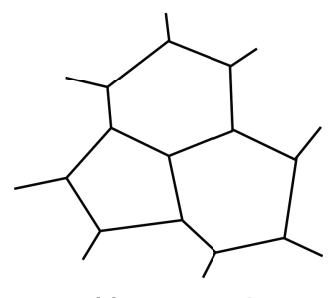

Hexagonal

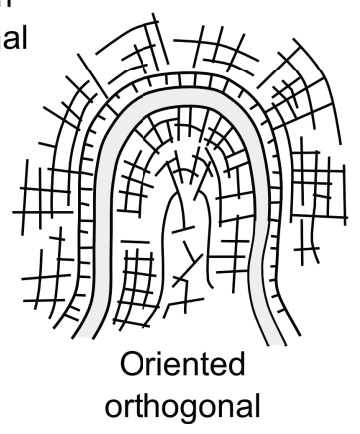

Figure 2.4: Examples of ice-wedge polygon patterns, modified from French $(2007$, Figure 6.3). 


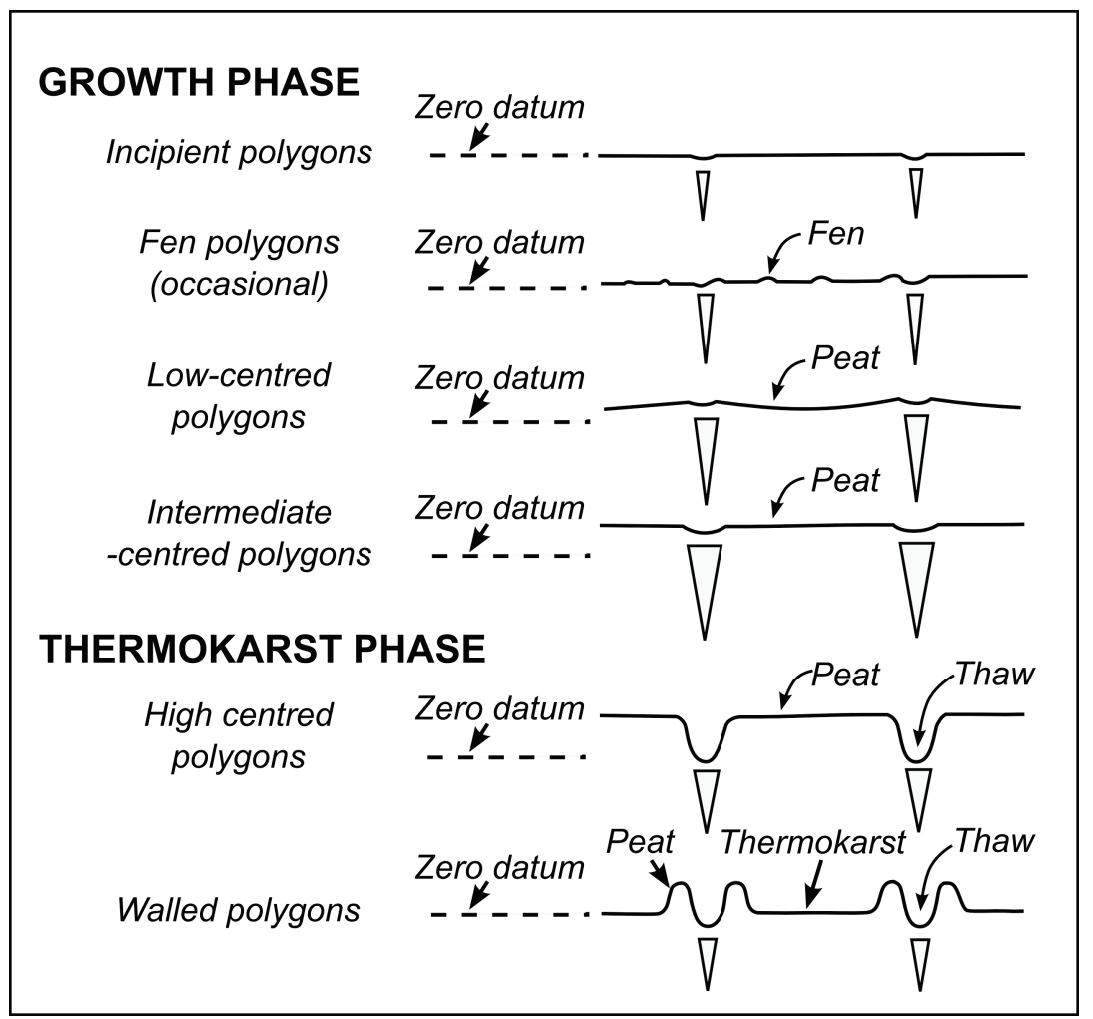

Figure 2.5: Classification system for ice-wedge polygons in flat areas, modified from Mackay, 2000, Fig. 2). 
in volumetric excess ice contents up to $40 \%$ (Shur and Zhestkova, 2003). However, permafrost thaw and refreezing after a surface disturbance, such as thermokarst, does not lead to the re-development of the original cryostructures, but to thin ice lenses and lower excess ice contents (Lawson, 1983).

\subsubsection{Ground ice in drained lake basins}

In drained lake basins, near-surface excess ice is primarily segregated ice and wedge ice. At Illisarvik, a lake basin drained by J.R. Mackay in 1978, thermal contraction cracking and wedge-ice development began the first winter after drainage, but ceased after 12 years due to vegetation growth and increased snow accumulation Mackay and Burn, 2002). Only four isolated ice wedges developed during that period. In older drained basins on the Arctic Coastal Plain of Alaska and Siberia, wedge ice constitutes up to $22 \%$ of the upper permafrost volume Kanevskiy et al. 2013; Ulrich et al., 2014). In old basins with well-developed networks, wedge-ice volume is higher in the centre of basins than in the margins. In younger basins, where ice-wedge polygons were less developed, there is a greater density in the margins than in the centres (Jorgenson and Shur, 2007). Near Point Barrow, on the Beaufort Coastal Plain, Billings and Peterson (1980) noted that ice-wedge polygons appeared around lake margins soon after the artificial drainage of four thermokarst lakes. They attributed this to the re-activation of previous ice wedges, preserved beneath shallow littoral shelves during lake expansion. At Illisarvik, one ice wedge was reactivated after drainage, but only for a short period of time Mackay and Burn, 2002).

The ice-rich zone at the top of permafrost extended to $60 \mathrm{~cm}$ beneath the top of permafrost in 2010 at Ilisarvik, with little segregated ice and no excess ice

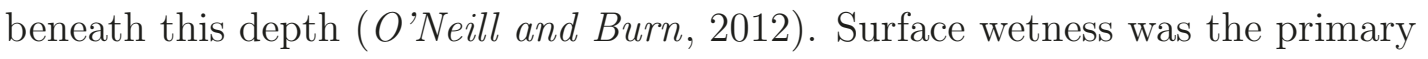
control on near-surface segregated ice content, and sediment texture appeared secondary. In older drained basins on the Arctic Coastal Plain of Alaska, 
ice-enrichment of the top of permafrost has been enhanced by ice aggradation due to the development of an organic layer and to the thinning of the active layer, and as a result the ice-rich zone extends to near $3.75 \mathrm{~m}$ depth Hussey and Michelson, 1966; Lawson, 1983; Jorgenson et al., 2003; Kanevskiy et al., 2013). Very little excess ice was observed beneath this ice-rich zone in boreholes extending up to $40 \mathrm{~m}$ deep (Lawson, 1983). Consistently, extensive vertical exposures through truncated thermokarst lake basins in the Tuktoyaktuk Lowlands have not revealed any massive ice bodies beneath drained lake basins (Murton, 1993).

\subsection{Thermokarst lakes}

\subsubsection{Definitions and significance}

'Thermokarst' describes the processes and landforms associated with the surface deformation and collapse that can result from thawing of ice-rich permafrost Jorgenson, 2013; Kokelj and Jorgenson, 2013). Thermokarst processes may initiate following a change in subsurface or surface conditions due to, for example, climatic warming, forest fires, or industrial activities. Thawing of ice-rich ground results in loss of volume and cohesive strength. On hillslopes, this may lead to the development of features such as retrogressive thaw slumps Burn and Lewkowicz, 1990) or active-layer detachment slides (Lewkowicz, 1990), whereas on flat terrain settlement of the ground surface may lead to the development of thermokarst lakes and ponds. Once thermokarst is initiated, direct exposure of permafrost to moving water or air, ponding on the ground surface, or disturbance of the vegetation cover may facilitate further permafrost degradation and thermokarst expansion Kokelj and Jorgenson, 2013). Increases in rates of thermokarst initiation associated with recent trends in climate have been reported from NW Canada Lantz and Kokelj, 2008), Alaska (Jorgenson et al., 2006), and Siberia (Fedorov and Konstantinov, 2003). The following paragraphs focus on the development and life cycle of 
thermokarst lakes, which dominate the OCF landscape.

\subsubsection{Talik development}

Thermokarst lakes develop as depressions, formed by thawing of icy permafrost in flat terrain, and become preferential loci for water accumulation (Burn, 1992). Ponding accelerates degradation of permafrost by prolonging the thaw season and shortening the duration of the period with sub-zero temperatures at the ground surface. If thaw penetration in sediments beneath the pond exceeds the depth of seasonal frost penetration, a body of perennially unfrozen ground, or talik, develops Mackay, 1992). At equilibrium, talik boundaries beneath lakes are vertical near the surface Mackay, 1963; Smith, 1976; Burn, 2002). For expanding thermokarst lakes that do not freeze to the bottom, talik depth increases with the square root of time since submergence (Burn and Smith, 1990; West and Plug, 2008). Numerical solutions based on mean annual lake-bottom temperatures have been used to

calculate transient talik configurations near shifting water-land boundaries Hwang and Smith, 1973; Ling and Zhang, 2004; West and Plug, 2008; Kokelj et al., 2009).

Few models of talik development consider parts of the lakes where water freezes to the bottom (Burn, 2002, Ling and Zhang, 2004), as the persistence of an active layer in the lake bottom complicates predictions of thaw penetration, and it is sometimes assumed that permafrost will be sustained beneath such shallow water (e.g. Rowland et al., 2011, Matell et al., 2013). Stevens et al. (2010) examined permafrost sustainability beneath bottom-fast ice in the outer Mackenzie Delta, and found that thermal conditions are not only affected by the duration of ice-contact with the sediment but also by snow conditions on the ice surface during this period. Field observations in lakes of the Mackenzie Delta area and in the outer Delta channels suggest that permafrost may be sustained beneath water that is less than 2/3 of the maximum ice thickness (Mackay, 1992, Burn, 2002; Stevens et al., 2010).

The second research component of this thesis, presented in Chapter 5, 
examines talik initiation and development near thermokarst lake shores in a tundra area of OCF. Field measurements of talik depths near shorelines with varying recession rates, bathymetries, and on-ice snow conditions were compared with approaches used to predict permafrost degradation beneath lakes of the Mackenzie Delta area and central Yukon. Inconsistencies were investigated using a numerical model of ground freezing and thawing to improve the understanding and ability to predict talik development near thermokarst shores.

\subsubsection{Controls on lake bathymetry}

The lake bottom subsides as the talik expands and, at equilibrium, the elevation difference between the original ground surface and the bottom of the lake reflects excess ice content in the ground thawed during talik development Mackay, 1992; West and Plug, 2008; Hinkel et al., 2012). On the Alaskan North Slope, lakes up to $25 \mathrm{~m}$ deep have been reported from areas of Yedoma sediments where syngenetic wedges and segregated ice extend tens of metres below the surface Carter, 1988; Hopkins and Kidd, 1988). In areas where excess ice only occurs in the upper layers of permafrost, such as where sediment has been re-worked by a previous generation of thermokarst lakes (Lawson, 1983), lake basins are shallow and flat-bottomed Hopkins and Kidd, 1988; West and Plug, 2008; Morgenstern et al., 2011).

Commonly, thermokarst lakes in clastic deposits have littoral shelves made of sands whose front separates deeper water in the lake centre from shallow water $(<1$ m) beneath which permafrost is preserved (Burn, 2002; Murton, 1996, 2001). In fine sediments, such as glaciolacustrine silts and clays, littoral shelves are not common and subsidence of the lake bottom leads to a 'pan-shaped' or a 'bowl-shaped' bathymetry (West and Plug, 2008; Hinkel et al., 2012). 


\subsubsection{Shore erosion and lake expansion}

Thermokarst lakes expand laterally because their shores are subject to: thaw subsidence following conduction of heat from the lake into the sediment; slumping where denuded permafrost is exposed to the air; thermo-mechanical erosion where there is contact between water and permafrost; and block failures where banks have been undercut Aré, 1973, Grosse et al., 2013). These processes may bring masses of organic and inorganic material into the lake for sorting and redistribution along the lake bottom Hinkel et al., 2012; Grosse et al., 2013).

Rates of lateral expansion vary depending on sediment texture and ground-ice content, lake geometry, bathymetry, water level, and permafrost conditions around the lake (Burn, 1992, 2013; Brouchkov et al., 2004). Average expansion rates up to $5.0 \mathrm{~m} \mathrm{a}^{-1}$ have been recorded in the Lower Anadyr Lowlands in Siberia, $2.0 \mathrm{~m} \mathrm{a}^{-1}$ in the Hudson Bay Lowlands and interior Alaska, and $1.2 \mathrm{~m} \mathrm{a}^{-1}$ in central Yukon (Jones et al., 2011) (Table 2.2). Growth of a thermokarst lake will continue until the surrounding ground ice is exhausted, the lake drains, or the basin becomes in-filled by sediment, aquatic plant, or peat growth (Burn, 1992).

\subsubsection{Controls on lake geometry and orientation}

Oriented lakes are groups of lakes possessing a common, preferred, long-axis orientation van Everdingen, 1998). They are common in Arctic and sub-Arctic lowlands such as the Alaska coastal plain Livingstone, 1954; Carson and Hussey, 1962; Hinkel et al., 2005), the Tuktoyuktuk Peninsula (Mackay, 1963; Côté and Burn, 2002), the SW coast of Banks Island (Harry and French, 1983), the coastal lowlands of northern Siberia Tomirdiaro and Ryabchun, 1973; Morgenstern et al. 2011), and other Arctic regions including OCF in the northern Yukon Price, 1968, Allenby, 1989). French (2007) describes several distinct forms of oriented lakes including D-shaped lakes, oval, elliptical, triangular, and rectangular lakes. He 


\begin{tabular}{|c|c|c|c|}
\hline & Region & Rate $\left(\mathrm{m} \mathrm{yr}^{-1}\right)$ & Source \\
\hline \multirow{2}{*}{ Canada } & Central Yukon & Mean $=0.7[3]$ & Burn and Smith (1990) \\
\hline & $\begin{array}{c}\text { Hudson Bay } \\
\text { Lowlands }\end{array}$ & $\operatorname{Max}=2.0$ & Dyke and Sladen (2010) \\
\hline \multirow{7}{*}{ Alaska } & Seward Peninsula & Mean $=0.37[370]$ & Jones et al. (2011) \\
\hline & Teshekpuk Lake & Mean $=0.70[13]$ & Arp et al. (2011) \\
\hline & \multirow{2}{*}{ Fish Creek } & \multirow{2}{*}{ Mean $=0.1$} & Jorgenson and \\
\hline & & & Shur 2007) \\
\hline & Barrow Peninsula & Mean $=0.73[8]$ & Lewellen (1970) \\
\hline & E North Slope & Mean $=0.3$ & Schell et al. (1983) \\
\hline & Kobuk Valley & $\operatorname{Max}=0.50[22]$ & Necsoiu et al. (2013) \\
\hline $\begin{array}{l}\text { Qinghai } \\
\text { Tibet } \\
\text { Plateau }\end{array}$ & Beiluhe Basin & $\operatorname{Max}=1.8[1]$ & Lin et al. 2010 \\
\hline \multirow{4}{*}{ Russia } & Central Yakutia & $\operatorname{Max}=0.52[2]$ & Aré and Balobaev 1979) \\
\hline & Lower Anadyr & $\operatorname{Max}=5$ & Tomirdiaro and \\
\hline & & & Ryabchun (1973) \\
\hline & Rogovaya & $\operatorname{Max}=0.59[76]$ & Sannel and Kuhry (2011) \\
\hline Sweden & Tavvavuoma & $\operatorname{Max}=0.71[43]$ & Sannel and Kuhry (2011) \\
\hline
\end{tabular}

Table 2.2: Reported rates of shore recession for thermokarst lakes from various regions, modified from Jones et al. (2011. Table 2). Where it is known, the number of lakes examined is indicated between square brackets. 
divides lake profiles in two broad categories: lakes with littoral shelves surrounding a central deeper pool, and shallow saucer-shaped lakes. In most cases, the long axes of the lakes are perpendicular to the prevailing wind direction $($ Seppälä, 2004$)$. The hypothesis that wind-induced currents result in preferential erosion of the ends of the lake and redistribution of sediments along the long-axis shorelines has been proposed to explain lake orientation (Black and Barksdale, 1949; Carson and Hussey, 1962, Mackay, 1963; Côté and Burn, 2002). However, according to French (2007), this hypothesis fails to explain the elongation of small lakes where such currents cannot develop.

\subsubsection{Lake drainage and permafrost recovery}

In continuous permafrost, growth of a thermokarst lake often terminates with catastrophic drainage via fluvial tapping, expansion of adjacent lakes, truncation due to rapid coastal retreat, or overflow during snow melt initiating drainage by ice-wedge erosion (Mackay, 1988, Burn, 1992).

After a lake drains, permafrost aggrades in the exposed basin sediment if seasonal frost penetration exceeds thaw penetration during summer. The main controls on the rate of penetration of the freezing front are $\lambda$ of the frozen ground, $T_{p s}, L$, and $t$, the time since initiation of freezing. Assuming that ground thermal properties and water contents are homogeneous and that the ground is uniformly at $0^{\circ} \mathrm{C}$ prior to freezing, the depth of aggraded permafrost in a stable surface $z_{t}$, can be estimated using the Stefan solution (Williams and Smith, 1989, Burn, 2013):

$$
z_{t}=\sqrt{\frac{2 \lambda_{f} T_{p s} t}{L}}
$$

As permafrost aggrades, near-surface aggradational ice develops causing uplift of the basin floor Mackay, 1972; Mackay and Burn, 2002, Bockheim and Hinkel, 2012; O'Neill and Burn, 2012). Ice enrichment of the drained basin floor continues 
over time by incorporating meteoric water as ice veins and lenses. Expanding networks of ice wedges may cause further surface uplift and improved drainage of basin centres over centuries to millennia Eisner and Peterson, 1998; Bockheim and Hinkel, 2012; Regmi et al., 2012). On the Arctic Coastal Plain, Jorgenson and Shur (2007) noticed that differences in frost heaving between margins, dominated by coarse sediment, and centres, dominated by fine sediment, may result in elevation differences of up to $4 \mathrm{~m}$, making the sandy margins of drained lakes long-lasting depressions in the landscape while basin centres may heave back to their original elevations. They attributed this internal topography of drained basins to two causes: (1) differences in the thickness of thawed material available for frost-heaving under the shallow littoral shelves, where permafrost is sustained, versus the deeper lake centre, where a talik develops; and (2) sediment sorting and redistribution by wave action concentrating fine sediment with higher frost-heaving and frost-cracking potential near the lake centre (Jorgenson and Shur, 2007). Drained lake basins exhibiting a similar topography are found in several other Arctic lowlands (Fig. 2.6) where the surficial geology and lake bathymetry are markedly different from the Arctic Coastal Plain Grosse et al. 2013). In OCF, for example, lakes have developed in fine glaciolacustrine sediment and lack littoral terraces, but depressed margins and raised centres occur in several drained lake basins.

The third research component of this thesis, presented in Chapter 6, investigates the genesis of this topography in drained basins of OCF. Detailed examinations of relief, segregated and wedge ice distribution, and sediment stratigraphy are used to develop a modified landform development model adapted to conditions of OCF, and expand understanding of conditions which may lead to the genesis of wet, depressed margins in drained basins. 

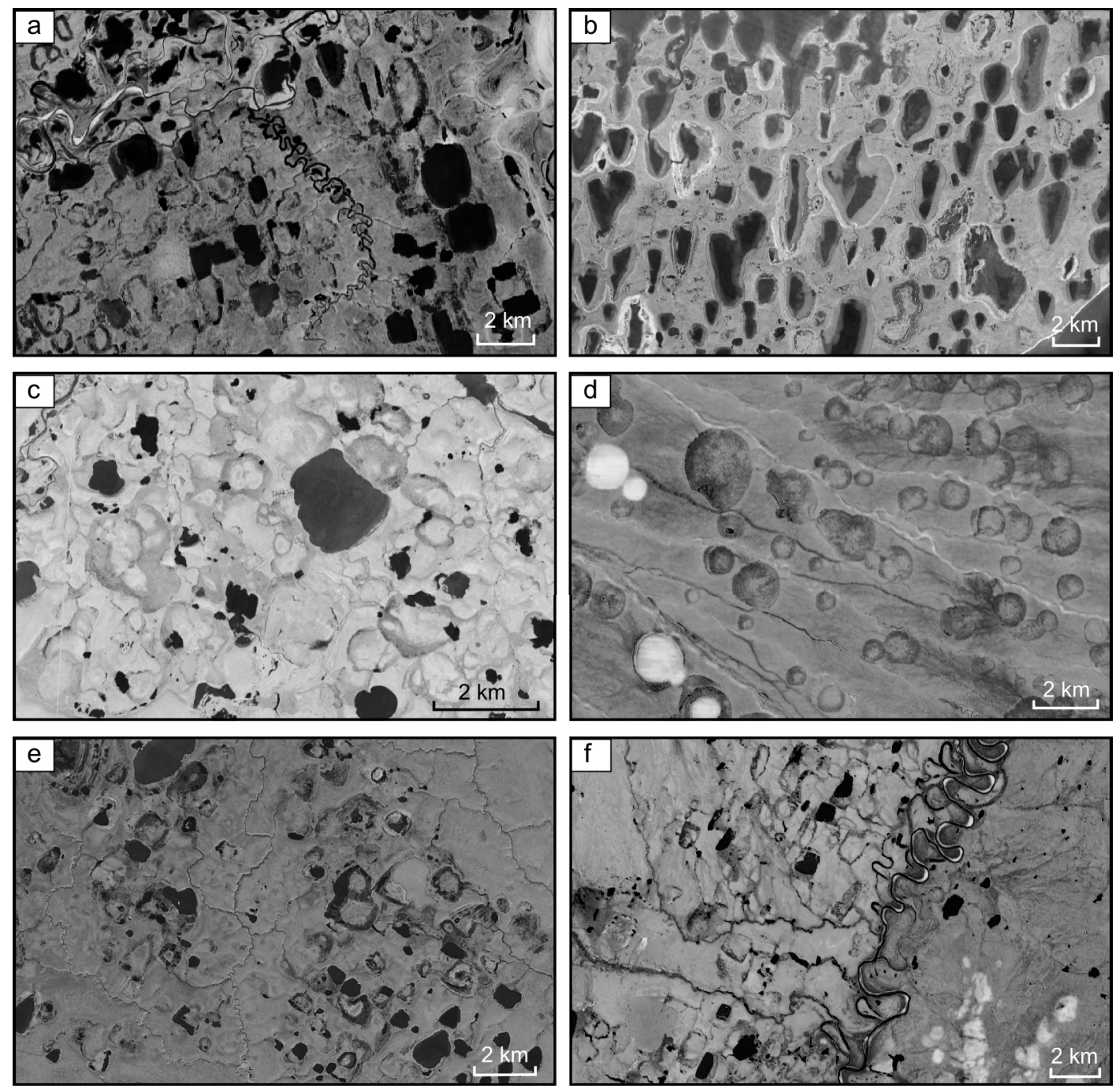

Figure 2.6: Areas where drained lake basins appear to have wet, depressed margins and drier ground near the basin centre: a) Fish Creek Area, Alaska, 70¹6.808'N, $151^{\circ} 15.260$ 'W (Google Earth, (C)2014 Digital Globe, picture taken on 12/08/2012); b) Tuktoyaktuk Peninsula, Northwest Territories, $70^{\circ} 0.305 \mathrm{~N}, 129^{\circ} 57.488 \mathrm{~W}$ (Google Earth, Landsat, IBCAO, (C)2014 Digital Globe; picture taken on 10/04/2014); c) N Seward Peninsula, Alaska, 66³1.617'N 164²16.884'W (Google Earth, NASA, (C)2014 Digital Globe; picture taken on 24/08/2006); d) Dewey Soper Bird Sanctuary, Baffin Island, Nunavut, 66 25.802N 7249.622W (Google Earth, Landsat; picture taken10/04/2013); e) Ayon Island, Chukotka, Siberia, 69³9.460, 169².476’E (Google Earth, IBACO, Landsat, picture taken on 10/04/2014); f) Penzhina River area, Kamchatka Krai, 6343.004N', 1680571'E (Google Earth, CDigital Globe, Landsat, picture taken on 10/04/2013). 


\subsection{Study area: Old Crow Flats, Yukon}

\subsubsection{Introduction: physiography and cultural significance}

OCF is part of a vast wetland complex, in the interior of northern Yukon, which includes two distinct basins: the Bluefish Basin, located S of Old Crow village, and OCF, to the $\mathrm{N}$ (Fig. 1.1). The basins, having an elevation of approximately $327 \mathrm{~m}$, are surrounded by the British and Barn mountains to the N (max. elevation 1655 m), the Old Crow range to the W (max. elevation $1270 \mathrm{~m}$ ), the Richardson Mountains to the E (max. elevation $1671 \mathrm{~m}$ ), and the Keele Range to the $\mathrm{S}$ (max. elevation $1395 \mathrm{~m})$.

The OCF basin encompasses $5600 \mathrm{~km}^{2}$ of peatlands forming a patchy mosaic of forest and tundra vegetation incised by entrenched meandering rivers. Thousands of shallow lakes cover more than one third of the land surface and form a freshwater landscape that is recognized as a wetland of international significance by the Ramsar Convention (The Secretariat of the Convention on Wetlands, 2014). OCF provides essential habitat to abundant wildlife populations and has long been a refuge for Arctic wildlife (Wolfe et al., 2011). The river bank bluffs have yielded the richest Ice-Age fossil record in Canada, including bones of woolly mammoths, steppe bison, horses, and ground sloths, as well as possible signs of human presence in the area as early as 40,000 to 35,000 years ago (Harington, 1977; Morlan, 2003).

OCF is within the traditional territory of the Vuntut Gwich'in and local observations indicate that the Flats are undergoing pronounced changes in temperature, precipitation, vegetation cover, lake-water levels, and wildlife distribution (Wolfe et al. 2011). The Vuntut Gwitchin First Nation (VGFN) is concerned that these environmental changes are linked to climatic warming and threaten the traditional activities and food security of their citizens. This concern was central to the development of Yeendoo Nanh Nakhweenjit Katrahanaht yaa (Looking after the land for the future), the Government of Canada International 
Polar Year project on environmental change and traditional use in OCF which included the research on thermokarst lakes presented in this thesis.

OCF is particularly well suited to an investigation of relations between permafrost conditions, lake expansion, talik geometry, and drained basin topography because: 1) it includes thousands of lakes, which are expanding and draining by thermokarst processes, and an abundance of drained lake basins; 2) it is located in the forest tundra ecotone and has a structurally heterogenous vegetation cover creating variable snow and ground temperature conditions; 3) VGFN citizens have expressed concern that climate change may be affecting the permafrost and lakes of OCF, which is their traditional territory; and 4) support through the International Polar Year and the NSERC Northern Research Chair programs made sustained field work in such a remote area possible.

\subsubsection{Geological structure and surficial deposits}

$\mathrm{OCF}$ is in a bowl-shaped depression that formed during the Laramide orogeny Gabrielse, 1967; Lawrence, 1973). There are two fault-bounded sub-basins aligned East-West and separated by the Timber Ridge anticline beneath OCF (Morrell and) Dietrich, 1993). A number of faults and lineaments cross the Old Crow region and are generally oriented NE-SW, in the Dave Lord Range and Richardson Mountains, and NW-SE in the British Mountains (Hughes et al. 1973). However, the bedrock underlying $\mathrm{OCF}$ is difficult to investigate as it is covered with over $55 \mathrm{~m}$ of fluvial and glaciolacustrine deposits deposited in the Neogene and Quaternary and there is only one bedrock outcrop in OCF, exposing Carboniferous shale, near the confluence of Timber Creek and Old Crow River (Morrell and Dietrich, 1993).

Old Crow Flats was not glaciated during the Wisconsinan Stage, but advances of the Laurentide Ice Sheet about 30 ka BP and again about 17 ka BP blocked eastward drainage at McDougall Pass and in Bonnet Plume Basin (Fig. 1.1 a). Glacially dammed water in the Bonnet Plume Basin was diverted through the Eagle 
River meltwater channel towards Glacial Lake Old Crow, which formed in the Bell-Old Crow-Bluefish basins (Fig. 1.1.) Zazula et al., 2004; Kennedy and Froese, 2008; Duk-Rodkin et al. 2004). The glacial lake had a maximum extent of approximately 13,000 $\mathrm{km}^{2}$, and drained westward at The Ramparts on Porcupine River near 14.8 ka BP, establishing the present-day westward drainage of Porcupine River (Zazula et al., 2004). Glacial Lake Old Crow deposited up to 10 metres of unfossiliferous glaciolacustrine silts and clays over the thick layered sands and silts which had accumulated in the basin during the Pleistocene Lichti-Federovich, 1973 , Matthews et al. 1987).

\subsubsection{Permafrost}

Ice-wedge pseudomorphs and involutions are found in Stratigraphic Unit 2 of the Porcupine River bluffs that is possibly >2.48 Ma (Matthews et al., 1987), suggesting that permafrost was present in OCF during the late Pliocene Pearce et al., 1982; Burn, 1994). However it is likely that permafrost degraded completely beneath Glacial Lake Old Crow and aggraded again in the exposed glaciolacustrine sediments following lake drainage (Lauriol et al., 2009). River-bank exposures indicate that the distribution of excess ground ice in the upper $40 \mathrm{~m}$ of deposits is limited to the glaciolacustrine sediments deposited by Lake Old Crow (Matthews et al., 1990).

Little is known of present permafrost conditions in OCF and the surrounding area. Ground temperatures from the area are limited to observations made during investigations for a community water supply during the late 1970s and early 1980s. At that time, $T_{g}$ near Old Crow was $-4.0^{\circ} \mathrm{C}$ at a depth of $15 \mathrm{~m}$ UMA Engineering. 1986) and permafrost thickness, measured in a geotechnical borehole drilled at Old Crow, was $63 \mathrm{~m}$ (EBA Engineering Consultants Ltd, 1982). In OCF, surface features indicative of ice-rich permafrost include high and low centre ice-wedge polygons, drunken forest, thermokarst ponds with subsiding shores, and rapidly receding lake shores. 


\subsubsection{Thermokarst lakes}

More than 2500 shallow lakes cover approximately $35 \%$ of OCF. The lakes are generally flat-bottomed and shallow, with an average depth of 1 to $1.5 \mathrm{~m}$ and a maximum depth of $4 \mathrm{~m}$ Gray and Alt, 2001). Many of these lakes likely formed by thermokarst processes during the early Holocene hypsithermal Mackay, 1992; Burn, 1997), when July temperatures in OCF were approximately $6^{\circ} \mathrm{C}$ higher than today (Lauriol et al. 2002), but some of the earliest lakes may have developed from remnant ponds after the drainage of Glacial Lake Old Crow (Ovenden, 1985).

Today, the lakes of OCF exhibit the key features of the thermokarst lake cycle, such as lake expansion and drainage followed by permafrost recovery and lake re-initiation Britton, 1967; Billings and Peterson, 1980; Jorgenson and Shur. 2007). Signs of lake expansion by thawing of ground ice include steep undercut banks with dangling peat curtains, spruce trees leaning towards the water on bank tops, as well as partly submerged shrubs and trees marking where land recently subsided into the lakes (Roy-Léveillée and Burn, 2010). Drained lake basins abound throughout OCF and, whereas many include remnant ponds of various sizes, some basins are completely covered by polygonal tundra. In many basins the centre is raised and better drained than the depressed margins, where ponding is common. Several drained basins have very deeply incised outlet channels indicating that drainage tends to occur catastrophically.

Many of the lakes and drained basins of OCF have rectilinear shorelines and tend to be oriented either NE-SW or NW-SE. The origins of these morphometric characteristics are unclear, and have been attributed to the underlying geological structure (Price, 1968; Allenby, 1989; Morrell and Dietrich, 1993), to wind-generated currents (Yukon Ecoregions Working Group, 2004), to ice-push and wave action (Gray and Alt, 2001, Roy-Léveillée and Burn, 2010), and to glacial activity (Grosswald et al., 1999). Roy-Léveillée and Burn (2010) reported shore 
recession rates up to $3.5 \mathrm{~m} \mathrm{yr}^{-1}$ for rectilinear shores of oriented lakes in OCF, and suggested it is unlikely that the morphometry of such rapidly receding shores is controlled by underlying faults transmitted through the thick overlying sediment. It is also unlikely that the orientation of OCF lakes results from the drumlinization and tectonization of the area by glaciers, since the area is located outside the maximum extent of the Laurentide ice sheet and was covered by a glacial lake (Fig. 1.1). The hypotheses based on wind-generated currents, wave action and ice-push have not been tested in $\mathrm{OCF}$.

\subsubsection{Vegetation}

OCF is located within the forest-tundra ecotone of northern Yukon, with subarctic boreal forest dominating to the south and tundra to the north. The vegetation cover is a heterogeneous mosaic of woodlands, tall shrubs, low shrubs, and herbaceous communities. Woodlands and tall shrubs dominate the southern and western parts of OCF but polygonal tundra with low shrubs and herbaceous vegetation is widespread and dominates in the central, northern, and eastern parts of OCF (Turner et al., 2014a).

There are few topographic effects in OCF but small differences in slope or soil texture affect local water content and the ability of trees to propagate. On steep slopes, where conditions are most favourable, white spruce (Picea glauca), white birch (Betula papyrifera), cottonwood (Populus balsamifera), and black spruce (Picea mariana) trees may be found. The incised beds of Old Crow River and its tributaries provide favourable terrain for the establishment of trees, leading to meandering forested corridors through the Flats Yukon Ecoregions Working Group, 2004). On the surface of OCF, subtle relief and variations in soil texture, created by the drainage of thermokarst lakes, cause variability in the vegetation cover.

Tussock tundra, often associated with low or tall shrubs, is the most widespread vegetation cover in OCF (Gray and Alt, 2001). The vegetation 
composition is similar to wetlands of the northwestern sub-Arctic and low Arctic, with cottongrass (Eriophorum vaginatum), dwarf birch (Betula glandulosa), labrador tea (Rhododendron subarcticum), bog bilberry (Vaccinium uliginosum), willow (Salix spp.), and a diversity and abundance of mosses (Ovenden and Brassard, 1989).

Where drainage is improved by a subtle slope gradient on the Flats, the ground is hummocky and the understorey is dominated by an assemblage typical of high boreal and subarctic wetlands with willow (Salix spp.), birch (Betula glandulosa), ericaceous shrubs, and lichens (Ovenden and Brassard, 1989; Gray and Alt, 2001). This vegetation cover constitutes the understorey of many stands of sparse spruce (Picea glauca and P. mariana) and tall shrub thickets with willow (Salix spp), dwarf birch (Betula spp.), and alders (Alnus spp.).

Thickets of tall shrubs dominated by willows also occur in recently drained basins where they are associated with an understorey of grasses and sedges Gray and Alt, 2001). Reedgrass (Calamagrostis spp.) meadows occur in the drier parts of recently drained lakes and near the margin of lakes that have partially drained and reduced in size. Such grassy meadows are similar to those that occur in recently drained lakebeds on the Arctic coastal plain (Ovenden, 1985).

Near the margins of these thermokarst lakes and ponds are abundant submergent plant communities of pondweed (Potomogeton spp.), emergent communities of bur-reeds (Sparganium hyperboreum), and fens of fibrous floating mats dominated by sedges (Carex aquatilis) and bog-bean (Menyanthes trifoliata) or dense, wet, meadows of grasses (Arctophila fulva) and sedges (Carex aquatilis). Similar fen vegetation develops in the depressed margins of old drained basins, in wet low centre polygons and near the margins of residual ponds Gray and Alt, 2001). 


\subsubsection{Hydrology}

Residents of Old Crow report decreasing lake water levels in the lakes of OCF and increasing frequency of catastrophic lake drainage. This is consistent with the results of remote-sensing analyses by Labrecque et al. (2009) indicating that there was a 3.5\% decrease in lake surface area in OCF between 1972 and 2001. Labrecque et al. (2009) suggest this was in part due to a negative water balance affecting lake-water levels from 1988 to 2001.

Turner et al. (2010) indicate that the hydrological regime of the OCF lakes differs depending on the characteristics of the surrounding vegetation. Where a high proportion of the vegetation cover is woodlands and tall shrubs, the lake water balance is dominated by input from snowmelt until mid-summer. Where the land cover has high proportions of dwarf shrubs and herbaceous vegetation, leading to a vigorous redistribution of snow by wind during winter, the main water input for the lakes is rainfall. Lakes in the latter category, as well as lakes with smaller catchments, are particularly vulnerable to water level draw down by evaporation during summer and many have decreased in size since the 1950s Bouchard et al. 2013; Turner et al., 2014a).

The decrease in lake area observed in OCF between 1972 and 2001 is also associated with the catastrophic drainage of two large lakes, Netro and Sandwich lakes (Labrecque et al. 2009). Catastrophic lake drainage is a natural part of the thermokarst lake cycle and there is no clear evidence that its frequency has increased under current climatic trends in the Tuktoyaktuk Coastlands Marsh et al., 2009). However, Lantz and Turner (personal communication) indicate that the frequency of catastrophic drainage in OCF increased between 1951 and 2009, and they ascribe this trend to recent increases in precipitation and air temperature. 


\subsubsection{Climate}

The climate of the Old Crow area is continental, as the British and Barn mountains separate the region from the maritime influence that moderates air temperatures at the Arctic coast (Wahl, 2004, Burn, 2012). During winter, a continental Arctic airmass dominates the area with only occasional intrusions of warm moist air from the Pacific (Gray and Alt, 2001; Wahl, 2004). Mean January temperatures at Old Crow are $-29^{\circ} \mathrm{C}$ (Fig. 2.7), the lowest in Yukon, and on average only $108 \mathrm{~mm}$ of precipitation fall between October and April. During summer, OCF is within the Arctic frontal zone, resulting in variable weather where warm and dry conditions can quickly give way to cool gusting weather Gray and Alt, 2001; Serreze et al., 2001). Mean air temperature in July is $15^{\circ} \mathrm{C}$ (Fig. 2.7), with mean daily maximum temperatures $\geq 20^{\circ} \mathrm{C}$ in June, July and August (Environment Canada data are available at http://climate.weather.gc.ca/index_e.html, accessed on October $26^{\text {th }}$, 2014). Mean annual precipitation at Old Crow is about $100 \mathrm{~mm}$ higher than at nearby stations on the western Arctic coast (Burn, 2012). The bulk of this precipitation difference occurs during summer, as $61 \%$ of the annual precipitation falls between May and September (Fig. 2.7).

At Old Crow, winds 4 to $8 \mathrm{~m} \mathrm{~s}^{-1}$ occur less than a quarter of the time and are more common during summer than winter. Winds greater than $10 \mathrm{~m} \mathrm{~s}^{-1}$ occur sporadically (Yukon Ecoregions Working Group, 2004). All winds are primarily from the NE. This dominant wind direction may result from the NE-SW trending valley in which Old Crow is located (Gray and Alt, 2001). However, during the 2008 and 2009 open water seasons (June - August), Roy-Léveillée and Burn (2010) also found a pronounced dominance of NE winds in a tundra area in SE OCF. Wind speeds were higher in OCF than at Old Crow in 2008-09. For instance, calm conditions $\left(<0.3 \mathrm{~m} \mathrm{~s}^{-1}\right)$ were three times less frequent whereas fresh and strong breezes $\left(8-13.8 \mathrm{~m} \mathrm{~s}^{-1}\right)$ were two times more frequent in OCF than at Old Crow. 


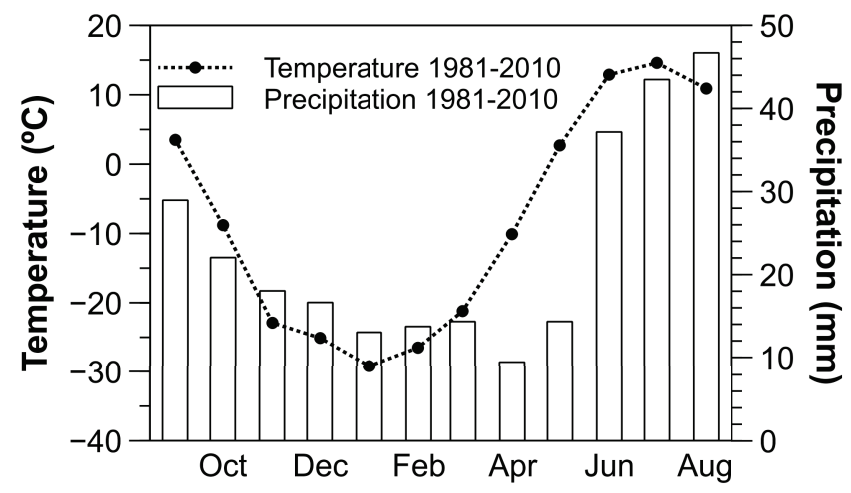

Figure 2.7: Climatic normal (1981-2010) air temperature and precipitation at Old Crow (Environment Canada data are available at http://climate.weather.gc.ca/index_e.html, accessed on October $26^{\text {th }}, 2014$ ). 
The climate record at Old Crow is incomplete and relatively short (1951-2007). There is insufficient data to discuss trends in precipitation, however a regional temperature composite record indicates a clear warming trend between 1930 and 2000 (Porter and Pisaric, 2011). Over this period, winter, spring, and summer temperatures warmed by $1.9^{\circ} \mathrm{C}, 1.6^{\circ} \mathrm{C}$, and $1.2^{\circ} \mathrm{C}$ respectively, whereas autumn temperatures decreased by $0.4^{\circ} \mathrm{C}$ (Wolfe et al., 2011).

Climatic simulations for the $21^{\text {st }}$ century by coupled general circulation models generally predict increases of 4 to $5^{\circ} \mathrm{C}$ in summer temperatures and 9 to $12^{\circ} \mathrm{C}$ in winter temperatures in the Old Crow area, with a decrease of 30 to 60 days in the number of days where air temperature descends below $0^{\circ} \mathrm{C}$ (Maloney et al., 2013). Precipitation is predicted to increase by 25 to $30 \%$, with a higher precipitation increase during summer (Bintanja and Selten, 2014). Storm frequency and intensity is also predicted to increase, but simulation results vary amongst models Harvey et al., 2014).

\subsection{Summary and concluding remarks}

The thermal regime of permafrost is affected by the air temperature regime, the conditions at the ground surface, the thermal conditions in the active layer, the thermal properties of the permafrost, and the geothermal heat flow. Changes in ground surface conditions, such as warming of air temperatures, thickening of the snow pack, or ponding at the ground surface can result in permafrost degradation through a thickening of the active layer or the development of a talik. Cycles of permafrost degradation and aggradation linked to thermokarst lake development and drainage control the topography of Arctic lowlands, and thus patterns of soil moisture, vegetation, and fluxes of carbon dioxide $\left(\mathrm{CO}_{2}\right)$ and methane $\left(\mathrm{CH}_{4}\right)$ from the surface of these areas.

Thermokarst lake expansion and drainage exhibit different responses to 
current climatic trends in different parts of the Arctic, emphasizing the relevance of examining the controls on patterns of permafrost degradation and aggradation in different places. Doing so also allows us to test models and assumptions developed in one area against conditions in a different area in order to improve our understanding of the contextual sensitivity of immanent processes, such as the influence of regional climate, surficial deposits, and ground-ice content on thermokarst lake development. OCF offers such an opportunity, as the majority of the work conducted on thermokarst lakes in the western Arctic has focused on lakes with littoral shelves and comparatively little has been conducted on flat-bottomed lakes. Similarly, many of the lakes examined in the literature have developed in sandy plains or Yedoma deposits, whereas the lakes of OCF developed in glaciolacustrine silts. 


\section{Chapter 3}

\section{Methods}

\subsection{Introduction}

This chapter situates the thesis in the context of methodological discussions in the literature by presenting an overview and discussion of the study design and a critical examination of key methods and associated assumptions. The study design for this research on permafrost and thermokarst lakes in OCF involved a field-based investigation of lakes and drained basins, which were used as case studies. The research was part of a Canadian International Polar Year (IPY) project aiming to examine environmental change in $\mathrm{OCF}$ through a partnership between researchers

and the local community (Wolfe et al., 2011). As a result, community relations were an important part of research activities and the methods used for community engagement are discussed below in Section 3.2 . Section 3.3 examines the decision to conduct a field-based study, and discusses issues related to generalization from case studies. Finally, Section 3.6 presents a critical discussion of key methods used in the development of the integrated chapters, including techniques pertaining to ground temperature measurements, delineation of talik geometry, assessment of segregated ice content in near-surface permafrost, and definition of ground thermal properties in numerical simulations of talik development. The specific data collection and analysis methods used for the three research components are described in detail in the integrated chapters, and Section 3.4 is used to complement this information by adding a deeper discussion of assumptions and uncertainties where necessary. 


\subsection{Approach to community participation}

Since the late 1990s, there has been increased emphasis on the involvement of local communities in northern research Graham and Fortier, 2005, Pearce et al., 2009; Brunet et al. 2014a b). The participation of local stakeholders in research enriches science with knowledge of characteristics and behaviour of the local environment (Hinkel et al., 2007, Burn, 2008; Eisner et al., 2009, Kokelj et al., 2012). It is acknowledged as a means to ensure the applicability of research findings and to build the capacity of local partners to utilize the results of science (Phillipson et al. 2012; Tsouvalis and Waterton, 2012, Brunet et al., 2014a). Such a vision is also present in reports on the state of northern research presented to NSERC, which highlight the need for partnerships between researchers and northern communities through the definition of research objectives, the planning of research programs, and the application of research results Task Force on Northern Research, 2000, Graham and Fortier, 2005). These ideals were also present in the International Polar Year program of the Government of Canada, which aimed to involve northern residents in scientific research activities, through training programs, communications activities, and in the management and administration of the program (Government of Canada IPY website: http://www.api-ipy.gc.ca/pg_IPYAPI_012-eng.html, accessed October 21st, 2014).

In the case of the IPY project on environmental change and traditional use in OCF, the Vuntut Gwitchin First Nation (VGFN) acted as lead and, in 2006, invited NSERC Northern Research Chairs to begin the development of a collaborative research program aligned with the scientific priorities and local engagement ideals of the Government of Canada IPY Program. This project was one of very few fully endorsed IPY programs led by northern-based individuals or aboriginal organizations in Canada (Church, 2009). The definition of overarching research goals, the acquisition of research funding, the planning of research programs, and 
the management of field logistics were the results of joint efforts between researchers and VGFN (Wolfe et al. 2011). This context facilitated community relations during the research on permafrost and lakes presented herein.

Local land managers and local residents were consulted at all stages of design and implementation of this research. Meetings were held in Old Crow in winter 2007, 2008, and 2009 to discuss research questions, logistics, and results with community members and local land managers. The involvement of local youth was ensured through interactive classroom presentations, coordination of multi-day field outings with researchers, and hiring and training of local youth to work as research assistants and participate in the presentation of research results during community meetings. Research results were communicated to local government and community members through reports, oral presentations at the community centre, and illustrated plain-language summaries that were distributed by hired youth to each community household. The bulk of knowledge exchange with local community members took place during extended field outings for data collection in OCF. Evenings at camp, in particular, offered opportunities to share perspectives and observations related to land use, environmental change, and thermokarst processes. Ten community members worked as field assistants on this research project and approximately 260 days were shared at camps in OCF.

This level of community engagement falls short of the ideals of participatory research (Wilmsen et al., 2008; Brunet et al. 2014a.b), which include the integration of traditional knowledge, self-reflection, and conscious engagement with power in relationships between researchers and community members. In participatory research, local communities have full ownership and control over the research process and researchers act as facilitators. This was not the case for this IPY project, as plans for each research component were controlled and defined by researchers after community input. However, the effort dedicated to community engagement in this research constitutes a departure from a mode of scientific knowledge production 
which operates independently of the local context where it may have socio-economic implications, to an approach where knowledge is developed through partnerships between researchers and local communities (Brunet et al., 2014a).

\subsection{Field-based research}

Northern terrain science is built on a strong tradition of field-based research, where presence in the field is central to the formulation of research questions and the testing of hypotheses (e.g., Apollonio et al., 1961; Mackay, 1963; Mackay and Burn, 2002; Boon et al., 2010; Clarke, 2014). However, northern locations are difficult and costly to access, and the option of spending an extended period in the field is not always available. With recent technological developments, large amounts of data can be obtained with only minimal time spent at the sites, and sophisticated modelling tools allow the mathematical representation and resolution of problems of increasing complexity (Church, 2013). As a result of these advancements, and due to the financial and logistical constraints associated with field work, field-based activities are becoming less central to northern terrain research and computer-based research is increasing in importance.

The research presented in this thesis had a predominant field component, which was facilitated by the availability of financial support from IPY Canada and the NSERC Northern Chair program, and by local logistical support was available from VGFN and the residents of Old Crow. A field-based approach was deemed most appropriate for this research as little knowledge of field conditions in OCF is recorded in the scientific literature, and information on permafrost and ground thermal conditions there are particularly scarce. The evolution of thermokarst lakes varies from region to region throughout the Arctic, yet the effects of local environmental conditions on lake bathymetry, geometry, shore erosion mechanisms, expansion rates, drainage mechanism, and permafrost recovery are not well 
understood (Carroll et al. 2011). This limits our ability to generalize current understanding of thermokarst processes to new areas, and further investigations of thermokarst lakes need to be situated through a careful examination of the environmental configuration characterizing the landscape where they are evolving. Finally, communication with local community members is facilitated by extended periods of time 'on the land'. At field camps, the experience and skills of local residents are valued on a day to day basis, and often required for project success. This creates a balance of power between researchers and local residents, and facilitates open and candid dialogue.

Field-intensive data-collection campaigns were designed to address research questions and, as commonly happens during extended stays in the field Harden, 2013), further questions and hypotheses were developed as a result of unexpected observations. For example, exploratory measurements of active-layer depth near different lake shores indicated that, surprisingly, thaw depth may be $>1.2 \mathrm{~m}$ beneath water $10-\mathrm{cm}$ deep and $<1.0 \mathrm{~m}$ beneath water approximately three times deeper, and led to the investigation presented in Chapter 5.

\subsection{Complementary use of remotely-sensed images and numerical models}

A purely field-based approach to phenomenon recognition and description, however, is limited in space and time to processes and features which can be grasped within the human scale of perception (Church, 1996) and, in this research, remotely-sensed images of OCF and a numerical thermal model were used to broaden the field perspective and situate field results in the contexts of space, time, and current theoretical knowledge.

Remotely-sensed images were used to link observations at the local scale to patterns visible at the lake-basin scale and at the landscape scale. For instance, 
elevation data along a single transect were used to characterize a basin-scale topographical pattern observed on aerial photographs. These observations gained further significance when examination of satellite imagery indicated that such a topographical pattern is widespread at the landscape scale. Aerial photographs were also used to provide temporal context for observations in the field. For example, shore erosion rates measured over a span of three years were compared to estimates of shore erosion over a period of 45 years using historical aerial photographs.

The use of a numerical thermal model allowed unusual field observations of talik configuration to be situated in the broader context of immanent processes governing the freezing and thawing of the ground everywhere. For example, numerical simulations confirmed that, for a given mean annual lake-bottom temperature, differences in the ratio of freezing degree days to thawing degree days result in differences in the rate of permafrost degradation beneath the lake bottom. As talik geometry is difficult to observe, modelling provided reassurance that field observations were being interpreted consistently with current theory and, in turn, provided further support for the theoretical framework.

\subsection{Extensive and intensive approaches to study thermokarst lakes}

As scientific knowledge about a phenomenon increases, the research strategies adopted to further extend that knowledge may vary. For instance, data collection campaigns may be extensive, exploratory, and aim at describing population characteristics and potential links between variables, or they may be more intensive and focused on unravelling the mechanisms of energy and mass transfer between system components. Whereas the former approach leads to generalisation by empirical statistical means, the latter approach leads to generalisation by theoretical reasoning (Richards, 1996). A balance of research strategies is beneficial in a field of study. The overuse of extensive exploratory surveys may lead to the object of study 
being well inventoried and well described but poorly understood (Oke, 1982), whereas the results of intensive studies cannot be generalized without proper contextualization in space and time (Richards, 1996).

Through the second half of the 20th century the study of thermokarst lakes has combined extensive surveys and intensive studies to advance models of shore erosion, lake orientation, and thermokarst lake evolution (e.g. Black and Barksdale, 1949; Mackay, 1963, 1981, 1992; Britton, 1967; Carson and Hussey, 1962, Billings and Peterson, 1980; Harry and French, 1983). Since the beginning of the 21st century, in part due to the balance of technological advances and logistical constraints, there has been an increase in extensive investigations using remotely-sensed imagery focused on better characterizing thermokarst lake and basin populations at the regional and pan-Arctic levels (e.g. Yoshikawa and Hinzman, 2003; Frohn et al., 2005, Smith et al., 2005, 2007, Hinkel et al., 2007; Carroll et al., 2011; Jones et al., 2011; Regmi et al., 2012, Zhan et al., 2014). In OCF, the study of thermokarst lakes has been dominated by extensive surveys using remotely-sensed images and isotope analysis (Labrecque et al., 2009, Turner et al. 2010, 2014b). One study in the nearby Bluefish Basin (Fig. 1.1), used core samples extracted from the centre of drained basins to examine the Holocene evolution of thermokarst lakes (Fig. 1.1) Lauriol et al., 2009).

\subsubsection{The use of cases in this research}

The research presented in this thesis used a case-study approach to examine the configuration of permafrost and lakes in OCF and to improve understanding of the underlying processes controlling this configuration. Specific sites were chosen as representative examples of broad vegetation cover categories to investigate ground temperatures in $\mathrm{OCF}$ and controls on the spatial variability of permafrost temperature within the forest-tundra ecotone. Four shorelines were used to investigate near-shore talik configuration in $\mathrm{OCF}$ and controls on permafrost 
degradation beneath shallow water. Three drained basins were used to investigate the topography of drained basins in a tundra area of OCF and to develop a model for the development of such a topography in areas where lakes lack littoral shelves and developed in fine sediment. Hence, specific sites within OCF were used to infer knowledge about $\mathrm{OCF}$ and, further, to generate insight into immanent processes that may be transferable to other lowlands affected by thermokarst lakes.

Such a case study approach was chosen to allow for an investigation of permafrost configuration and thermokarst processes that is informed by a careful examination of local conditions. For instance, the assessment of permafrost temperatures in OCF informed the investigations of permafrost degradation beneath shallow water and permafrost aggradation in drained basins. The geometry of near-shore taliks was considered in the context of the local air and lake-bottom temperature regimes, the development of on-ice snow drifts, the shore erosion rates, and the thermal properties of the underlying sediment. This assessment of talik development near receding shores in turn informed the investigation of relief in the drained basins. Again, the careful examination of conditions in drained basins and comparison with conditions in surrounding lakes provided insight in the processes controlling the development of depressed margins in old drained basins. This use of an intensive rather than an extensive research strategy allowed for the use of techniques, such as the extraction of permafrost cores with a CRREL drill and the measurements of talik depth by jet-drilling, which do not lend themselves well to the collection of a large number of samples.

However, the use of an intensive approach in a study area, such as OCF, where few previous studies have been conducted presents important limitations as it is difficult to properly contextualize an intensive study in a poorly described landscape. The distribution of morphometric characteristics of lakes and drained basins in OCF was examined superficially for the purpose of situating the study area within $\mathrm{OCF}$ and the lakes and basins within the surrounding landscape. 
However, more elaborate surveys of conditions in OCF including extensive descriptions of lake morphometry, erosion rates, and depth distribution, as well as proper mapping of the vegetation cover structure, would have facilitated a better spatial contextualization of this research within OCF.

\subsubsection{The selection of cases}

Contrary to the rules for the selection of "sampling sites" in the context of sampling theory (Strahler, 1954; Chorley, 1966), the theoretical basis for the selection of case studies for field investigations is generally poorly developed Richards, 1996). The lack of guidelines for the selection of cases may lead to the preferential examination of sites where the phenomenon of interest is particularly accentuated and a skewed perspective may result if cases are not properly situated in relation to the overall population (e.g. Lantuit et al., 2013). Bias in site selection also results from considerations of distance, time, access, safety, and landowner permission Harden, 2013). In northern science particularly, case study selection also is often opportunistic, controlled by severe logistical constraints, and situated after the fact within the population it is meant to represent (Powell, 2007). However, since the generation of general explanation from a case study is based on theoretical reasoning, the usefulness of the case depends less on the 'typicality' of the case than on the cogency of the theoretical reasoning and the meticulous consideration of the effects of local conditions on the fundamental processes of interest in the study (Richards, 1996).

\section{The selection of cases within OCF}

In this study, the main area where lakes and drained basins were investigated was located in low shrub tundra (Fig. 3.1 a, site 4). It was selected during a reconnaissance flight in 2007, because it included both very large and small lakes as well as easily distinguishable drained lake basins, all in close proximity to each 
other. This last point was crucial as transportation between sites was by foot and by small inflatable boat, limiting the span of the area that could be accessed with field equipment from a central camp location. Subsequent morphometric analysis revealed that lakes in this area were generally larger and more often oriented NE-SW or NW-SE than in other parts of OCF. A second area, located where taiga and tall shrubs dominate the vegetation cover, included lakes that were smaller and irregular in shape (Fig. 3.1 based on the existence of a winter camp and on viable snowmobile trails. It was used to examine spatial variability in permafrost temperatures.

Several factors inhibited intensive field work at this second area, including use of the lakes for muskrat trapping by local families who, understandably, did not want the lake bottom to be disturbed by jet-drilling during the ratting season. Lakes located in the low-shrub tundra of $\mathrm{OCF}$, on the other hand, were generally not used for ratting. Moreover, drained lake basins were much more difficult to identify where lakes were irregular and vegetation was tall. As a result, this study of thermokarst lakes is focused on lakes in the low shrub tundra of OCF. Lakes and drained basins are not included from parts of OCF where tall shrubs and taiga dominates and where lakes have irregular shorelines. Yet, the pronounced difference in ratting activity between low-shrub tundra areas and areas dominated by the tall shrubs and taiga suggests that there may be important differences in lake-bottom conditions between these areas. The difficulty in identifying drained basin outlines on aerial photographs where taiga and tall shrubs dominate may result from the tall vegetation cover, or may indicate that irregular lake basins evolve along a different post-drainage trajectory in these areas. Such hypotheses were not investigated in this thesis, and the selection of cases used for the intensive study of talik and drained basins does not allow for the generalisation of observed conditions to portions of OCF where the vegetation cover is not dominated by low-shrub tundra.

Within the low-shrub tundra surrounding the area used to investigate talik 


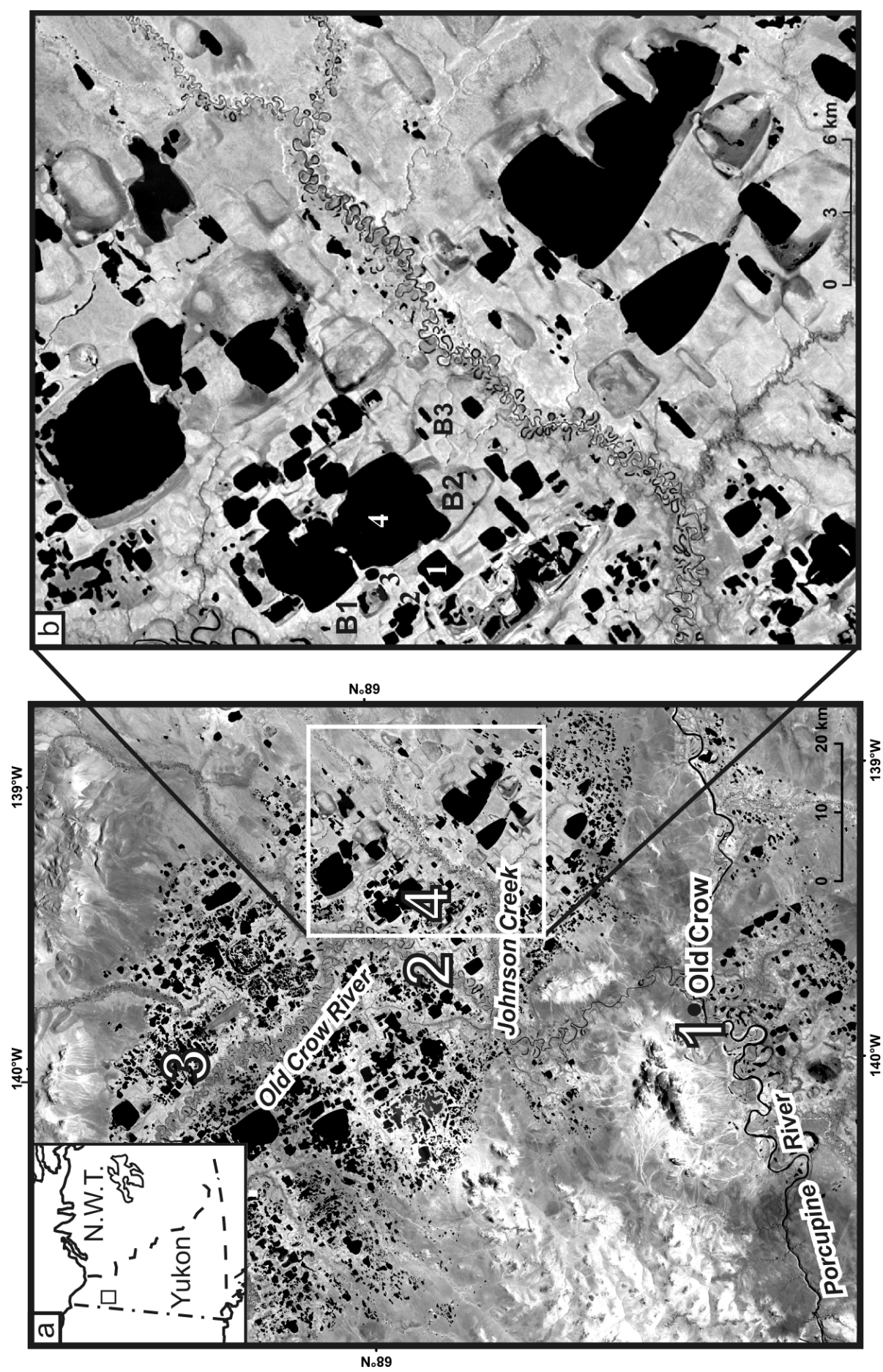

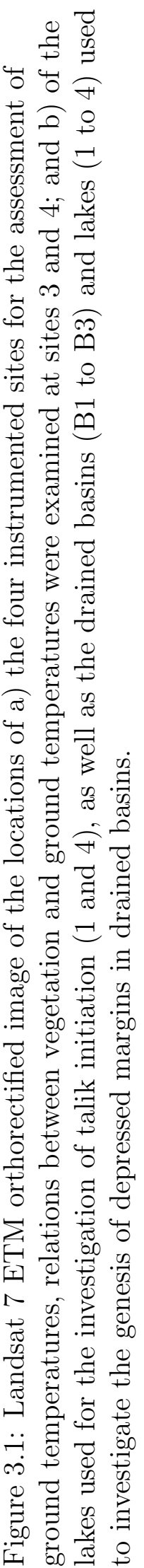


geometry and drained basin topography, the specific lakes and drained basins selected for study were representative of general lake and basin size and morphometric characteristics (Fig. 3.1b). The two lakes used for the examination of talik development were larger than average, however their geometry and the orientation of their shorelines were consistent with the majority of the surrounding lakes. The three basins used for the investigation of basin topography represented a range of sizes comparable to the distribution of basins in the area. The field sites had depressed margins and appeared to have drained and re-vegetated by 1951, as with the majority of drained basins in the area.

\section{Tundra lakes of OCF as a general case of thermokarst lakes}

The lakes and basins selected to be used as cases were comparable to the typical lakes and basins found in the surrounding area. However, the tundra lakes of OCF, as a case study for thermokarst lakes in general, appear to be exceptional in the current literature. For instance, as will be discussed in Chapter 5, talik initiation occurs beneath unusually shallow water in the tundra lakes of OCF. Moreover, as

will be discussed in Chapter 6, the margins of drained basins are depressed but key features linked to the development of such depressed margins, littoral terraces and sandy-gravelly beaches, are not found in the lakes of OCF.

The examination of exceptions in a general population may offer the opportunity to confront current models with cases that appear incongruous and difficult to explain, but offer the opportunity to evaluate and improve current understanding of immanent processes. Dismissing such exceptions to give significance only to congruous cases allows the consolidation of current models by accumulation of evidence, but misses the opportunity to advance understanding by testing it against cases that are compatible with normal assumptions, practices, and explanations Kuhn, 1962).

This study of tundra lakes and basins in OCF contributes to an improved 
understanding of thermokarst lakes beyond OCF by putting current understanding to the test at a site where the configuration of permafrost is unexpected. In the case of talik development, a numerical model was used to investigate how local conditions at the OCF site results in inconsistencies with assumptions and models that are effective in other thermokarst lakes.

\subsection{Key methods and limitations}

The specific methods used for data collection and analysis in this thesis are presented in detail in the three integrated chapters. The presentation of assumptions associated with these methods was practical and succinct, consistently with space constraints associated with publishing in peer-reviewed journals. The following paragraphs aim to complement this information, where necessary, by presenting additional discussion of key methods, including techniques pertaining to ground temperature measurements, delineation of talik geometry, assessment of segregated ice content, texture analysis and definition of ground thermal properties for numerical simulations.

\subsubsection{Temperature measurements}

Temperatures $1.5 \mathrm{~m}$ above the ground, $1.25 \mathrm{~m}$ below the ground surface, and on the lake bottom, were recorded using Onset HOBO H8 data loggers (Onset Computer Corporation, Cape Cod, Massachusetts, United States, factory specified time accuracy: +45 to -60 minutes per year at $0^{\circ} \mathrm{C}$ ). Air and top of permafrost temperatures were measured using thermistors (Onset TMC6-HA, resolution $\pm 0.4^{\circ} \mathrm{C}$ at $0^{\circ} \mathrm{C}$, factory-specified accuracy between $\pm 0.5^{\circ} \mathrm{C}$ and $\pm 1^{\circ} \mathrm{C}$ ) connected to data loggers that were sealed in electrical boxes (Fig. 3.2), whereas temperature at the lake bottom was measured on the internal sensor of the HOBO datalogger (range $-40^{\circ} \mathrm{C}$ to $100^{\circ} \mathrm{C}$, accuracy: $\pm 0.7^{\circ} \mathrm{C}$ and resolution: $\pm 0.4^{\circ} \mathrm{C}$ at $0^{\circ} \mathrm{C}$ ). We $\operatorname{did}$ 
not calibrate the data loggers and sensors used in Old Crow Flats, but calibration of a large number of similar loggers and sensors gave results consistent with the factory specifications, and no bias was found in the measurements Karunaratne, 2011; Ensom et al., 2012). For air temperature measurements, the temperature sensor was protected within a radiation shield installed $1.5 \mathrm{~m}$ above the ground surface (Fig. 3.2a).

For top of permafrost temperatures, the sensor was attached to the bottom of a wood dowel, which was inserted in a 1.25-m deep borehole (Fig. 3.2b and c). The HOBO data loggers used to monitor lake-bottom temperatures were placed in waterproof capsules that were attached to shore with steel line. The capsules were anchored to the lake bottom at the maximum extent of the steel line, perpendicular to the shoreline. Some data loggers may have drifted during spring break-up, but all data loggers were pulled out immediately after break-up, downloaded, re-launched and re-installed. No major shift in location was noted, although conditions did not always allow determination of the exact location of the capsule when retrieving it.

Temperature profiles to $15-\mathrm{m}$ depth were measured using thermistors mounted on cables inserted in steel pipe. Thermistors (BetaTHERM, 2.2K3A1A, resolution $0.01^{\circ} \mathrm{C}$, accuracy $\pm 0.05^{\circ} \mathrm{C}$ ) were calibrated in a laboratory ice bath made of finely crushed ice saturated with distilled water. The ice was stirred and excess water was removed from the bottom of the bath as melting occurred to maintain temperature of the ice bath at the ice point and avoid thermal stratification (Mangum, 1995). The calibrated thermistors were mounted on cables at depths of $0.5,1,1.5,2,3,4$, $5,7.5,10$, and $15 \mathrm{~m}$. The cables were installed to depths of $15 \mathrm{~m}$ below the ground surface in bore holes drilled by water-jet (Fig. ??). Channels were dug during jet drilling to ensure minimal ponding at the ground surface, and the blocks of vegetation were replaced once drilling was complete to minimize disturbance of the ground surface. The bore holes were cased with steel conduit with an interior diameter of $2.54 \mathrm{~cm}$ (Fig. ??b). Steel pipe was used despite its high thermal 

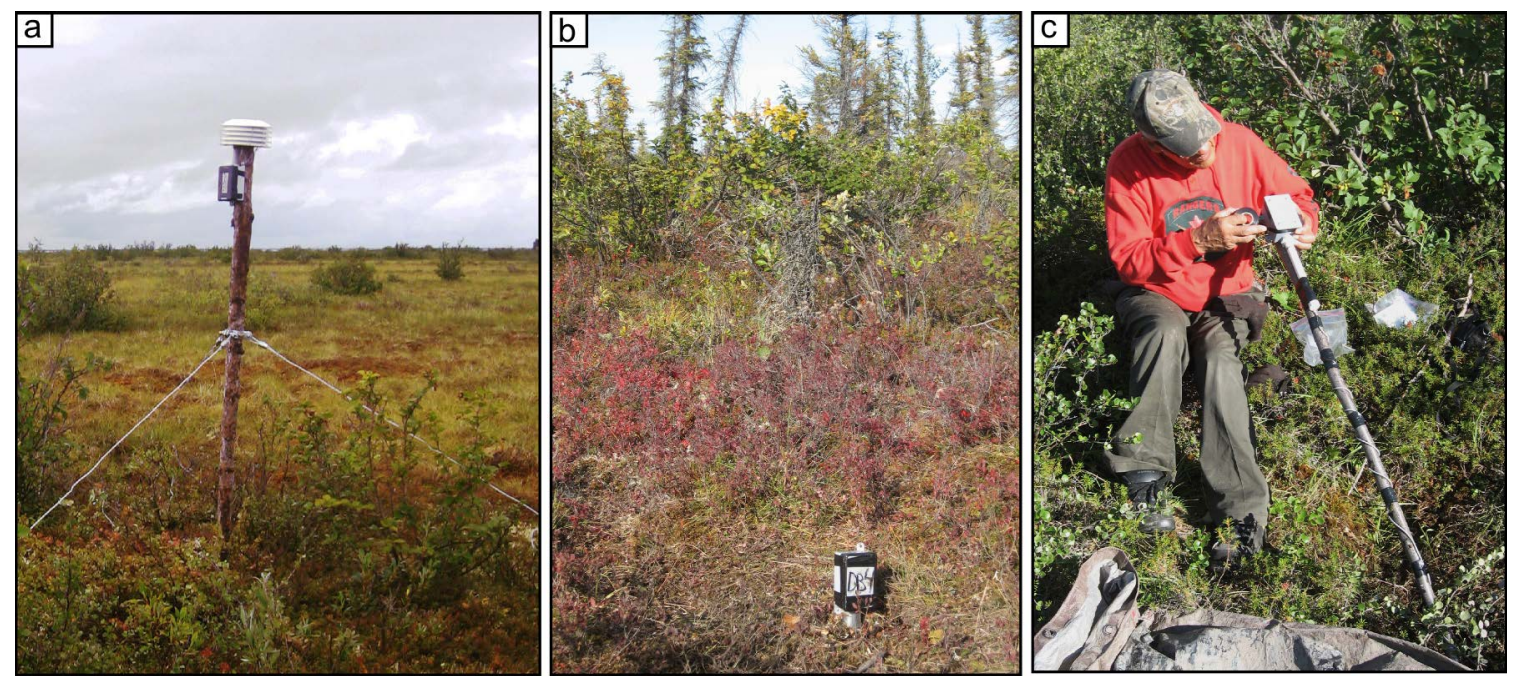

Figure 3.2: Field installations for the measurement of a) air temperature and b) and c) top of permafrost temperatures. 

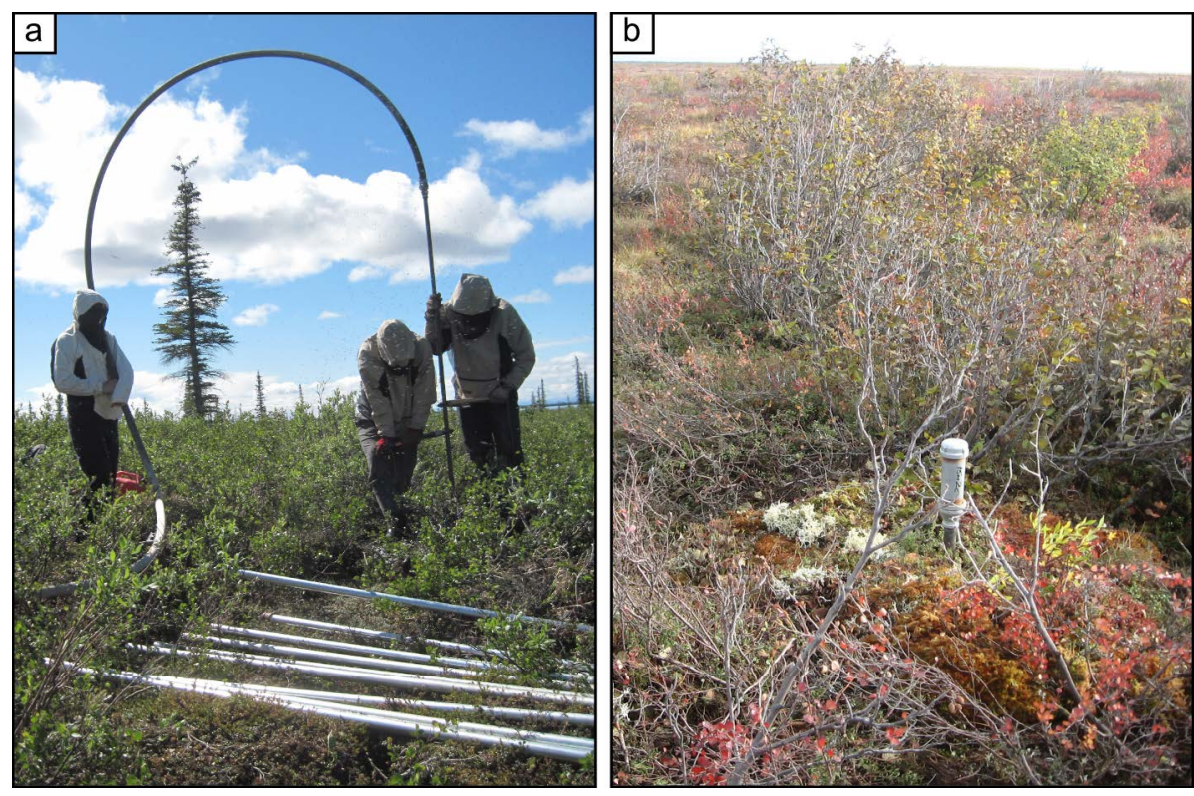

Figure 3.3: a) Field use of a water-jet drill and b) installed casing for a thermistor cable. 
conductivity because it can withstand environmental stresses in the field such as damage by wildlife.

Measurements were collected with a calibrated multimeter in March, May, June, August, and September of 2009 and 2010 to estimate the thermal envelope, and in July of 2011, 2012, and 2013 to record temperature at the depth of zero annual amplitude. Temperature measurements collected within the first year after site installation were excluded from data analysis to avoid the thermal influence of water-jet drilling. The thermal envelopes obtained compare to thermal envelopes from other similar locations (e.g. Kanigan et al., 2008) but higher and lower temperatures may have occurred during periods where data were not recorded, particularly between September and March, and the thermal envelopes obtained are a conservative estimate of thermal amplitudes along the profile. This does not affect temperature at the depth of zero annual amplitude.

Local community members objected to the addition of diesel in the pipes and nothing was added to prevent convective heat transfer in the space between the cable and the conduit wall during this study. Hence the measured temperature profiles may have been affected by convective heat transfer, particularly during winter when near-surface temperatures are much lower than $T_{g}$. Temperature measurements were likely least affected by convection in late summer and early fall, when temperature decreases with depth along the profile. $T_{g}$ did not vary by more than $0.05^{\circ} \mathrm{C}$ between seasons (Table 3.1), indicating that the effects of convective heat transfer on $T_{g}$ were negligible. Silicone oil has since been approved locally as a more acceptable alternative to diesel, obtained, and poured in the steel conduits as part of a long-term ground temperature measurement program at the sites.

Finally, $T_{g}$ sites were located $50 \mathrm{~m}$ from lake shores, which is within the range of distances where a warming influence from the lake is expected Kanigan et al., 2008). At one site, boreholes were drilled at sites with similar vegetation structure located 5, 50, and $100 \mathrm{~m}$ from shore to assess the effect of proximity to the lake on 


\begin{tabular}{lccc}
\hline & \multicolumn{3}{c}{ Temperature $\left({ }^{\circ} \mathrm{C}\right)$} \\
\cline { 2 - 4 } Site & August 2009 & May 2010 & March 2010 \\
\hline $\mathrm{a}$ & -5.37 & -5.36 & -5.38 \\
$\mathrm{~b}$ & -3.53 & -3.50 & -3.51 \\
$\mathrm{c}$ & -4.71 & -4.67 & -4.70 \\
$\mathrm{~d}$ & - & -4.57 & -4.57 \\
$\mathrm{e}$ & -5.01 & -5.03 & -5.04 \\
\hline
\end{tabular}

Table 3.1: $T_{g}$ measured in 5 boreholes in August 2009, May 2010, March 2010. 


\begin{tabular}{lccc}
\hline $\begin{array}{l}\text { Distance } \\
\text { from shore }(\mathrm{m})\end{array}$ & $\begin{array}{c}\text { Max. canopy } \\
\text { height }(\mathrm{m})\end{array}$ & Snow depth $(\mathrm{m})$ & $\begin{array}{c}\text { Median } T_{g} \\
(2010-13)\left({ }^{\circ} \mathrm{C}\right)\end{array}$ \\
\hline 5 & 0.30 & 0.32 & -3.4 \\
50 & 0.32 & 0.42 & -4.6 \\
100 & 0.57 & 0.42 & -4.5 \\
\hline
\end{tabular}

Table 3.2: $T_{g}$ in three boreholes located 5, 50, and $100 \mathrm{~m}$ from shore with snow depth, recorded in March 2010, and vegetation height at each site. 
$T_{g}$. There was a clear decrease in $T_{g}$ between 5 and $50 \mathrm{~m}$ from shore, but the difference between boreholes at 50 and $100 \mathrm{~m}$ from shore was minimal, with temperatures $100 \mathrm{~m}$ from shore slightly warmer than at $50 \mathrm{~m}$ (Table 3.2).

\subsubsection{Delineation of talik geometry}

In spring of 2009 and 2010, lake ice was used as a drilling platform to delineate the base of the sub-lake talik along lines perpendicular to four shorelines. Holes were augered in the ice at 10-m intervals to measure lake depths. Using these holes, talik depth beneath the lake bottom was estimated by sudden resistance to penetration of a water-jet drill (Burn and Smith, 1990; Burn, 2002).

A talik is defined as a body of unfrozen ground surrounded by permafrost. It may or may not be cryotic, depending on conditions, but should be unfrozen van Everdingen, 1998). In non-saline environments such as OCF, cryotic taliks may develop at temperatures near $0^{\circ} \mathrm{C}$ due to high unfrozen water content in fine sediment. However, thaw completion in ice-rich sediment coincides with the $0^{\circ} \mathrm{C}$ isotherm as bulk-ice thaws at $0^{\circ} \mathrm{C}$ (Williams and Smith, 1989).

Empirical equations presented by Andersland and Ladanyi 2003, Table 2.6) indicate that the unfrozen water content in silt loam sediment similar to OCF increases abruptly for temperatures above $-0.3^{\circ} \mathrm{C}$ (Fig. ??). Whereas silt loams are

frost susceptible, excess ice was scarce in permafrost cores extracted near the foot of a receding lake shore bank. In such a context of fine sediment without excess ice, jet-drilling may have overestimated talik depth whereas numerical simulations, which placed the talik boundary at $0^{\circ} \mathrm{C}$, likely underestimated thaw depth. The steepness of the unfrozen water content curve of silt loams constrains these overand under-estimations to a narrow temperature range very close to $0^{\circ} \mathrm{C}$, which may still be wide in space. Despite these opposing biases, numerical simulations were consistent with the talik depths measurements using jet-drilling. 

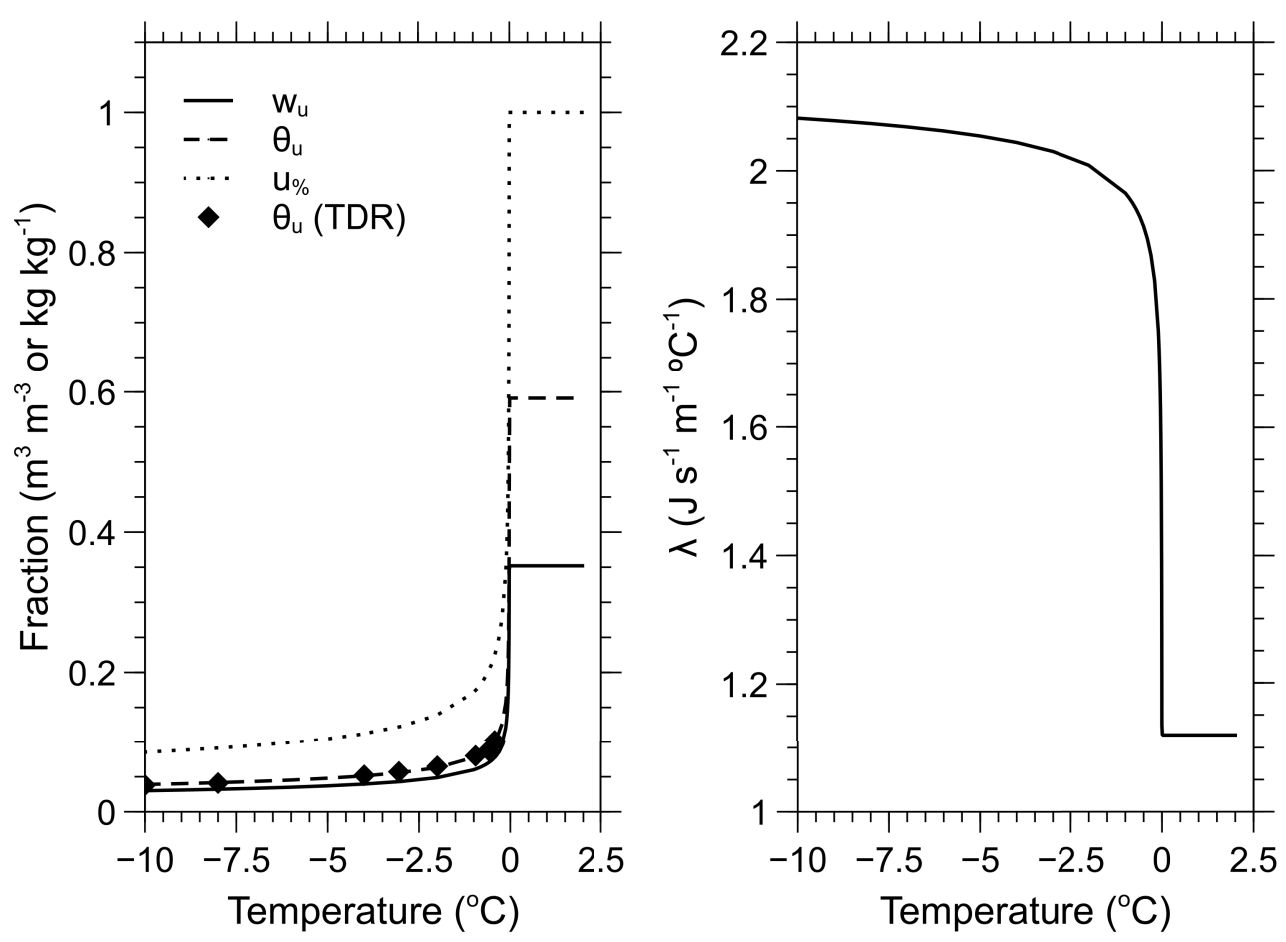

Figure 3.4: a) Gravimetric, volumetric, and $\%$ unfrozen water content $\left(w_{u}, \theta_{u}\right.$, and $u_{\%}$, respectively) curves for Athena silt loam calculated using Equation 2.1 with $\alpha=6.0$, and $\beta=-0.301$. The sand, silt, and clay fractions of this soil are comparable with these fractions in the OCF sediments. The dry density of the soil $\left(\rho, \mathrm{g} \mathrm{cm}^{-3}\right)$ used to calculate $\theta_{u}$ was 1.296 , the gravimetric moisture content was 0.352 and the volumetric moisture content was 0.456. $w_{u}$ measurements made using time domain reflectometry (TDR) by Smith and Tice (1988) are included for comparison. b) Thermal conductivity curve calculated based on Equation 2.2 and $u_{\%}$. 


\subsubsection{Estimation of segregated ice content}

Near-surface permafrost cores were extracted for analysis using a CRREL drill (Fig. 3.5) to assess stratigraphy and excess ice content. At each drilling site, the vegetation cover, microtopography, and organic-layer thickness were described. The use of drill shaft extensions allowed drilling to a maximum depth of $2.7 \mathrm{~m}$, but drilling depth was most often limited by the infilling of drill holes with water which, particularly in clayey sediment, created suction and prevented retrieval of the core samples. Core samples were measured and photographed immediately after extraction, and general notes were made on stratigraphy and visible ice structures. Only the most basic cryostratigraphic information was obtained for the cores, as summer conditions caused rapid thawing of the samples and the field laboratory was not equipped to preserve core samples in a frozen state.

Core samples were thawed, mixed, poured into beakers, and allowed to settle in the field (Kokelj and Burn, 2003). Beakers were weighed before and after settling to control for moisture loss due to evaporation. Volumes of saturated sediment $\left(V_{s s}\right)$ and supernatant water $\left(V_{s w}\right)$ were recorded to provide a conservative estimate of the volumetric excess ice content $\left(I_{v} \%\right)$ of the samples (Kokelj and Burn, 2003):

$$
I_{v}=\left[\frac{1.09 V_{s w}}{V_{c}}\right] 100
$$

Core volume $\left(V_{c}\right)$ was calculated from measurements collected in the field, when the extracted core was intact, and estimated based thawed volumes of sediment and water (Kokelj and Burn, 2003):

$$
V_{c}=V_{s s}+\left(1.09 V_{s w}\right)
$$

When the measured and calculated core volumes differed, the value yielding a lower excess ice content was used. Subsidence potential $(S P)$ was calculated for each core 

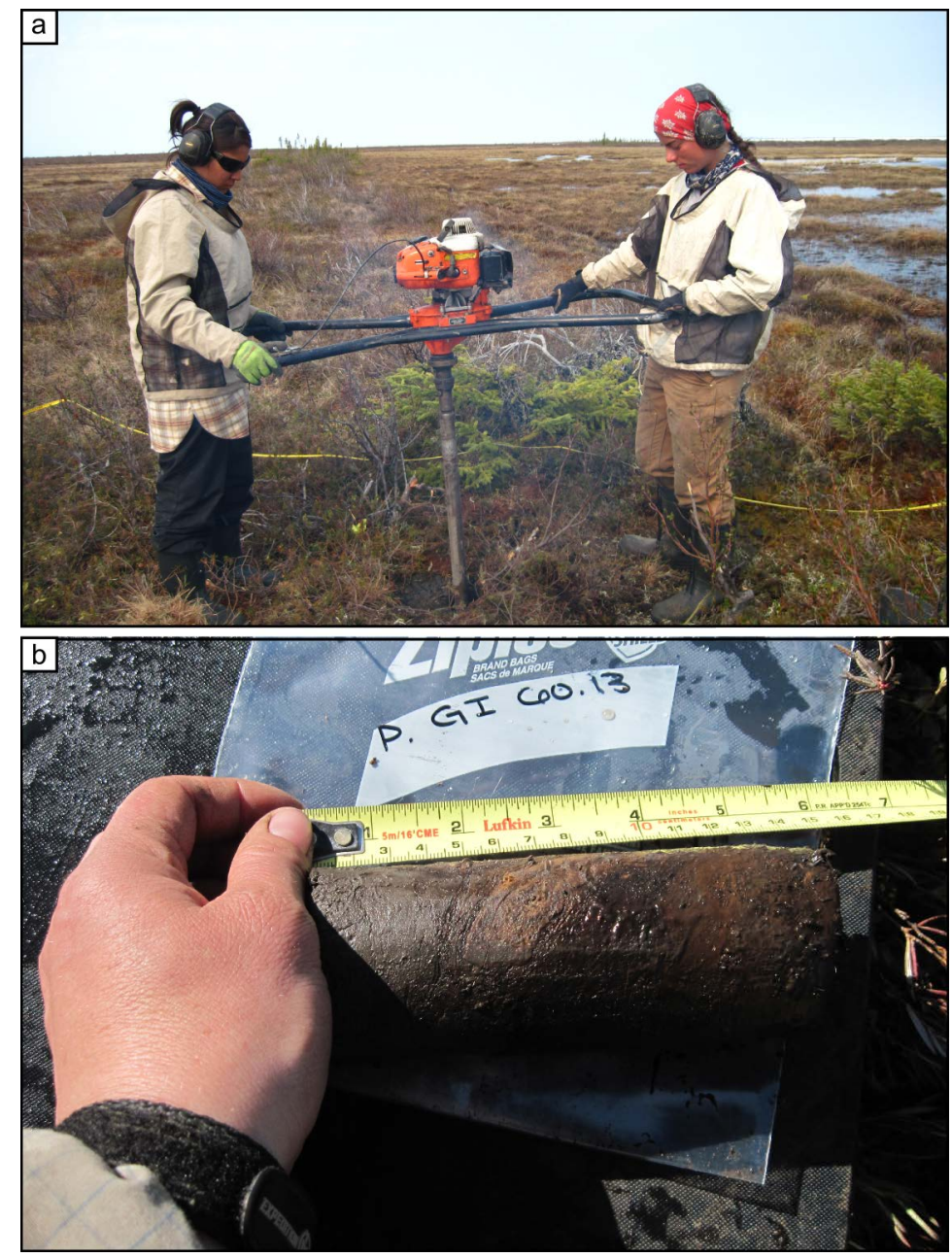

Figure 3.5: a) Field use of a CRREL drill and b) measurement of a permafrost core sample prior to packaging. 
sample by multiplying sample length by $I_{v}$. $S P$ for a drill site was the sum of $S P$ for all its core samples.

The boundary between $V_{s s}$ and $V_{s w}$ was difficult to measure accurately when the samples had high organic and clay contents. Such samples occurred in the margin and centre of basin 2 (Fig. $3.1 \mathrm{~b}$ ) and represented approximately $\sim 10 \%$ of all the samples collected. Settling time was extended for these samples, sometimes to several days, in order to reduce uncertainty in the assessment of excess ice content. In a few extreme cases, an uncertainty up to $\pm 12.5 \mathrm{~cm}^{3}$ remained after settling, which may have led to the underestimation of the cumulative thaw subsidence potential for the whole core by a few $(<5) \mathrm{cm}$ in some profiles of basin 2 . This would not be sufficient to affect key results.

\subsubsection{Sediment-texture analysis}

Sand, silt, and clay fractions for samples in two permafrost cores extracted from the bottom of Lake 4 (Fig. 3.1) were determined by the pipette method Sheldrick, 1984) and used to estimate characteristics of sediment beneath the lake bottom when modelling talik development (c.f. Chapter 5). Subsequently, 315 permafrost samples from drained basins were analysed for texture when investigating conditions in drained lake basins (c.f. Chapter 6). Due to the large number of samples, a Beckman Coulter LS 13,320 laser diffraction analyser (Neville et al., 2014) was used for grain-size analysis for this component of the thesis. The laser diffraction method is known to underestimate the clay fraction due to the general non-sphericity of clay particles (Beuselinck et al., 1998; Buurman et al., 1997). However, this bias is consistent between samples of a similar type and between samples from a similar source, thus allowing comparison between samples from different parts of a given lake basin (Buurman et al., 2001, 1997). 


\subsubsection{Representation of $\theta_{u}$ for numerical modelling}

The thawing characteristic curve was a function typical for silt loam (Fig. ??a), the grain size of the soil found at the study sites. It was calculated using parameters presented by Andersland and Ladanyi (2003, Table 2.6), which are based on measurements of unfrozen water content by time domain reflectometry conducted by Smith and Tice (1988, Appendix A). These measurements extended to $-0.4^{\circ} \mathrm{C}$ and direct use of such a data set would result in a gap in the unfrozen water content curve, where $22 \%$ of the total water content is unfrozen at $-0.4^{\circ} \mathrm{C}$ and at $0^{\circ} \mathrm{C}$ the water content is completely unfrozen. The parametric equation proposed by Andersland and Ladanyi (2003, Table 2.6) provides a basis for extrapolating the progressive increase in unfrozen water content from $22 \%$ to $100 \%$ as permafrost warms from $-0.4^{\circ} \mathrm{C}$ to $0^{\circ} \mathrm{C}$ (Fig. ??a). The thermal conductivity of the ground $(\lambda)$ was determined with Equation 2.2, by using this curve to calculate the portion of unfrozen water, $u_{\%}$ (Fig. ??b). 


\section{Part II}

\section{Integrated publications}




\section{Chapter 4}

\section{Ground temperatures in the Old Crow area}

\section{Modified from the manuscript published as:}

Roy-Léveillée P., Burn C. R., McDonald I. D. (2014). Vegetation-permafrost relations within the treeline ecotone near Old Crow, northern Yukon, Canada. Permafrost and Periglacial Processes 25, 127-125.

\subsection{Introduction}

Ecosystems north and south of the continental treeline have pronounced contrasts in vegetation structure, snow-pack characteristics and ground thermal regime Timoney et al., 1992b; Palmer et al., 2012). In the forest, ground temperature is controlled by climate, soil moisture content, organic cover, and snow thickness Kanigan et al., 2009). Snow-pack development there depends on precipitation and interception in the forest canopy Hedstrom and Pomeroy, 1998; Pomeroy et al., 2002). On the tundra, wind controls snow depth and density, creating persistent differences in soil temperature between shrub and nonshrub sites (Sturm et al., 2005; Morse et al., 2012; Lantz et al., 2013).

In North America, the forest-tundra ecotone extends from the northern limit of continuous forest to the northernmost position of arboreal growth Payette et al. 2001). This transition can cover a range of distances, and it is commonly a heterogeneous vegetation assemblage including patches of taiga, tall shrubs, and low shrubs with sedges (Timoney et al., 1992b; Payette et al., 2001; Lantz et al., 2010).

At macro-scales $(10 \mathrm{~km}$ to $1000 \mathrm{~km})$, snow thickness decreases northward across the forest-tundra ecotone, resulting in an associated decline in ground temperatures 
(Burn and Kokelj, 2009; Palmer et al., 2012). The heterogeneity of vegetation within the ecotone creates local $(10 \mathrm{~m}$ to $100 \mathrm{~m})$ variations in snow-pack characteristics (Pomeroy et al., 1995; Palmer et al. 2012). Variations in physical and ecological landscape characteristics are associated with spatial variability in permafrost temperatures (Romanovsky et al. 2010a; Ukraintseva et al., 2011).

In this chapter, we discuss ground temperature variation within the forest-tundra ecotone near Old Crow, northern Yukon (Fig. 4.1). The study area is described in Section 2.5 of this thesis. Data were collected in taiga, tall shrub $(>0.5$ $\mathrm{m})$, and low shrub $(<0.5 \mathrm{~m})$ patches in distinct ecological contexts. Our working hypothesis is that, within the patchy vegetation assemblages of this ecotone, ground temperature declines with decreasing height and snow-holding capacity of the vegetation, creating a heterogeneous ground temperature field. We present annual mean ground temperature $\left(T_{g}\right)$ at four locations (Fig. 4.1 and 4.2) characterised by: taiga with an understorey of tall shrubs (site 1); taiga with an understorey of low shrubs and sedges (site 2); heterogeneous vegetation dominated by tall shrubs and taiga (site 3); and heterogeneous vegetation dominated by low shrubs and sedges (site 4). Relations between vegetation, snow and annual mean near-surface permafrost temperatures $\left(T_{p s}\right)$ were examined at sites 3 and 4 . The purposes of this chapter are to present a first regional assessment of ground temperatures from the Old Crow area, and to examine the effects of heterogeneous surface conditions on ground temperatures within the forest-tundra ecotone. The installations for $T_{g}$ at sites 1 to 4 are infrastructure for long-term monitoring of ground temperatures to examine the effects of climate change on permafrost temperature in the forest-tundra ecotone of northwest Canada. 


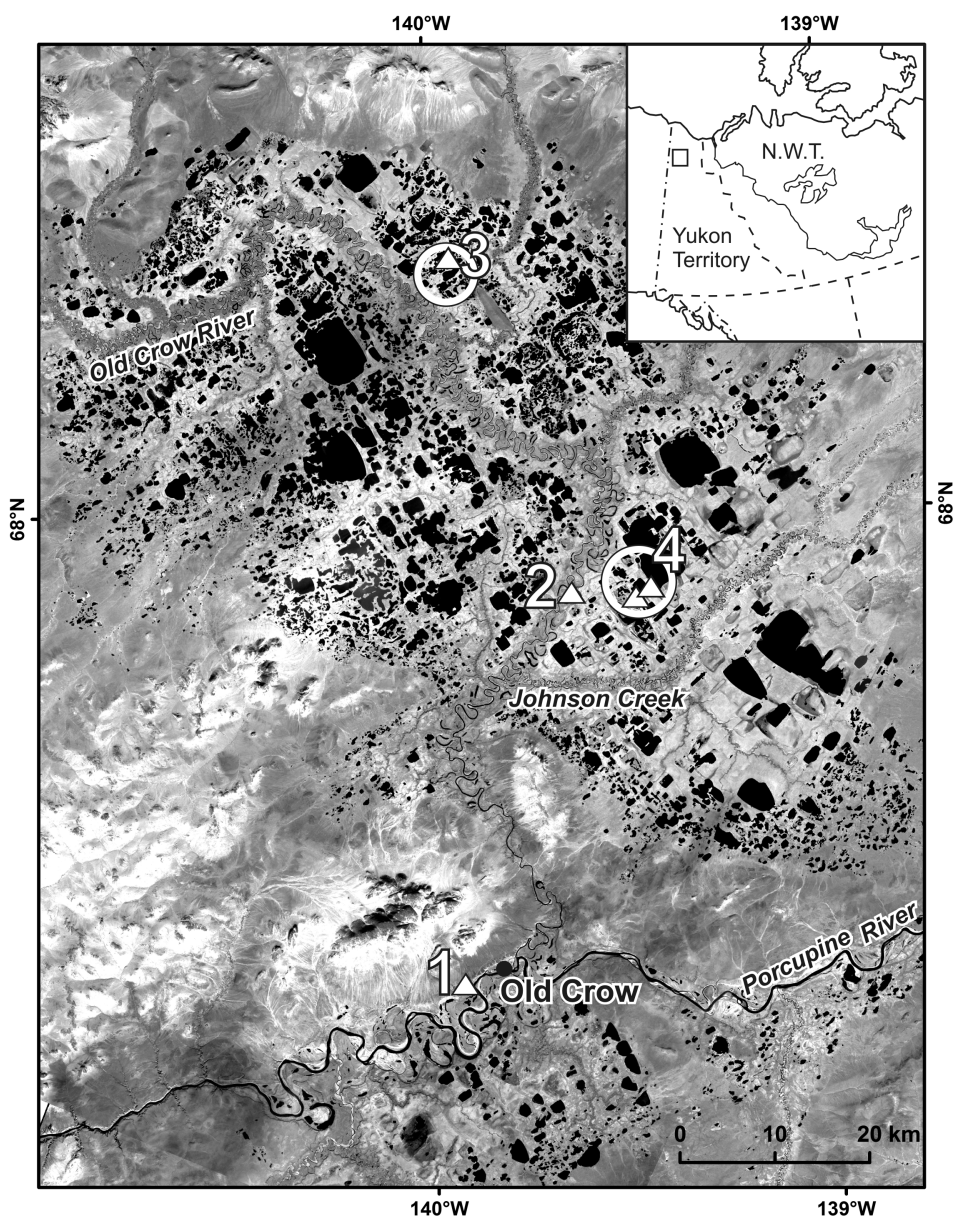

Figure 4.1: Landsat 7 ETM orthoimage of Old Crow Flats and the surrounding areas acquired on 30 August 2001. Waterbodies are in black. Permafrost monitoring sites 1 to 4 are indicated and borehole locations are marked with triangles. Coordinates for the borehole locations are: (1) N67.56 $6^{\circ} 139.91^{\circ}$; (2) $\mathrm{N} 67.93^{\circ} \mathrm{W} 139.64^{\circ}$; (3) $\mathrm{N} 68.24^{\circ} \mathrm{W} 139.94^{\circ}$; (4a) $\mathrm{N} 67.93^{\circ} \mathrm{W} 139.46^{\circ}$; (4b) $\mathrm{N} 67.92^{\circ} \mathrm{W} 139.47^{\circ}$. (C) Natural Resources Canada. 

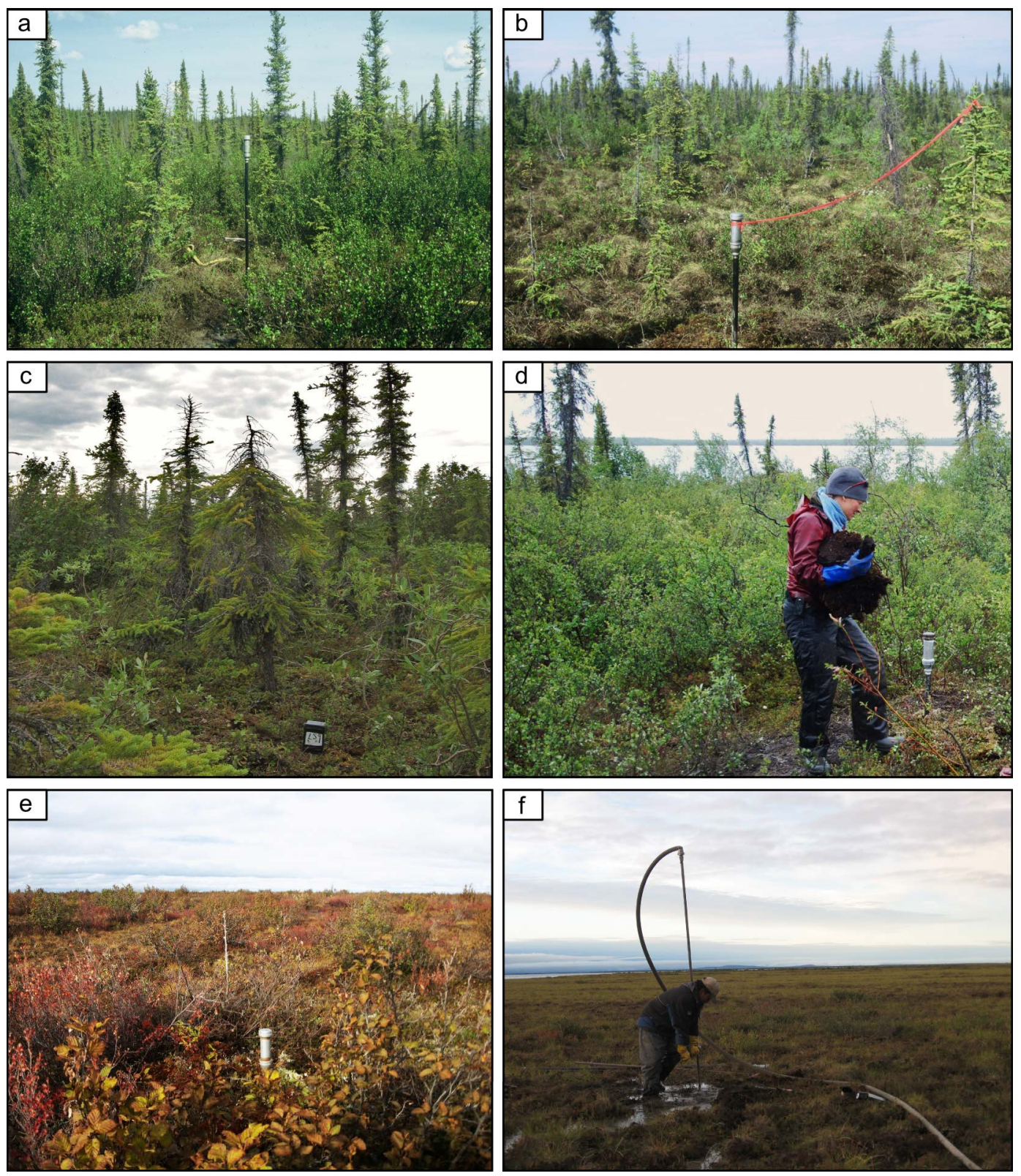

Figure 4.2: Ground temperature monitoring sites in the Old Crow area, northern Yukon: (a) site 1, taiga with tall shrubs: (b) site 2, taiga with low shrubs; (c) site 3, taiga patch; (d) site 3, tall shrub patch; (e) site 4, tall shrub patch; (f) site 4, low shrubs and sedges. 


\section{$4.2 \quad$ Field methods}

Four permafrost monitoring sites were established in the Old Crow area between 2006 and 2010 (Fig. 4.1). At each site, thermistor cables were installed in holes drilled by water jet to near the depth of zero annual amplitude (14.3 to $20.0 \mathrm{~m}$ ), where we have measured $T_{g}$. At this depth, permafrost temperature under undisturbed surfaces responds to long-term trends driven by climate Williams and Smith, 1989). All of the holes were drilled at least $50 \mathrm{~m}$ from the nearest waterbody, and cased with steel pipe of 2.54-cm diameter. Ten BetaTHERM thermistors (Measurement Specialties, Hampton, Virginia, United States) (2.2K3A1A, resolution $0.01^{\circ} \mathrm{C}$, accuracy $\pm 0.05^{\circ} \mathrm{C}$, calibrated in an ice bath) were placed on the cables and inserted in the casing to obtain ground temperature profiles on a continuing basis. Temperature measurements began 1 year after site installation to avoid the thermal influence of water-jet drilling.

At sites 3 and 4, air temperature was monitored every 2 h from August 2009 to August 2011 using miniature Onset HOBO H8 data loggers (Onset Computer Corporation, Cape Cod, Massachusetts, United States) placed in radiation shields located $1.5 \mathrm{~m}$ above the ground. At these sites, $T_{p s}$ was also recorded at several locations in patches of taiga, tall shrubs and low shrubs between 2008 and 2011. Thermistors (Onset TMC6-HA) were installed at $1.25 \mathrm{~m}$ depth and connected to data loggers which recorded temperature every $4 \mathrm{~h}$. The resolution of temperature measurements was $\pm 0.4^{\circ} \mathrm{C}$ at $0^{\circ} \mathrm{C}$, and the factory-specified accuracy was between $\pm 0.5^{\circ} \mathrm{C}$ and $\pm 1^{\circ} \mathrm{C}$. We did not calibrate the data loggers and sensors used in Old Crow Flats, but calibration of a large number of similar loggers and sensors gave results consistent with the factory specifications, and no bias was found in the measurements Karunaratne, 2011; Ensom et al., 2012). Wildlife destroyed a number of ground temperature instruments, and as a result several instrumented locations were used only for the determination of snow-vegetation relations. 
Vegetation surveys were conducted in summer 2009 around each instrumented location at sites 3 and 4 . The number, height and species of all trees within an area of $100 \mathrm{~m}^{2}$ centred on each instrument were recorded. Mean maximum canopy height was estimated using five to ten measurements within $5 \mathrm{~m}$ of each instrument. Snow surveys were conducted in late winter 2009 and 2010. Snow depth was measured ten times within $10 \mathrm{~m}$ of each instrument to calculate average snow-pack thickness.

These ten measurements were repeated at $10 \mathrm{~m}$ intervals along a $100 \mathrm{~m}$ transect, in order to assess how representative the instrument locations were of the surrounding terrain. A snow pit was excavated approximately $10 \mathrm{~m}$ from each instrument, and the thickness and density of each stratigraphic unit in the snow pack were measured to calculate a weighted average snow density for each location.

\subsection{Study sites}

\subsubsection{Site 1: taiga with a tall shrub understorey (Taiga-TS)}

In June 2006, a thermistor cable was installed to a depth of $16.5 \mathrm{~m}$ on a terrace of Porcupine River, approximately $3.5 \mathrm{~km}$ west of Old Crow (Fig. 4.1). Drilling encountered $1 \mathrm{~m}$ of organic matter, $8 \mathrm{~m}$ of organic-rich silt and $7.5 \mathrm{~m}$ of sand with gravel lenses. The elevation of the site is approximately $250 \mathrm{~m}$ a.s.l. The site is in a relatively uniform open-canopy forest of Picea mariana and P. glauca with an understorey of Betula spp., Rhododendron subarcticum, Vaccinium vitis-idaea and $V$. uliginosum over a ground cover of mosses (Fig. 4.2a). The trees are 2-4 m tall and horizontally separated by $2-3 \mathrm{~m}$.

\subsubsection{Site 2: taiga with a low shrub and sedge understorey (Taiga-LS)}

A second thermistor cable was installed in June 2006 to a depth of $20 \mathrm{~m}$ at an elevation of $260 \mathrm{~m}$ a.s.l. on a terrace of Old Crow River, $40 \mathrm{~km}$ north of Old Crow (Fig. 4.1). Drilling encountered $0.5 \mathrm{~m}$ of organic material overlying $19.5 \mathrm{~m}$ of sand 
with clay lenses. The site is in a relatively uniform open-canopy forest of $P$. mariana and P. glauca with a sparse understorey of Betula spp. and a ground cover of mosses and grassy tussocks (Fig. 4.2b). It is in the forest corridor along Old Crow River. The trees are 3-5 m apart.

\subsubsection{Site 3: tall shrubs and taiga}

Site 3 is located in the Old Crow Flats, $75 \mathrm{~km}$ north of the village, at approximately $305 \mathrm{~m}$ a.s.l. (Fig. 4.1). The area contains many small, irregularly shaped thermokarst lakes. The site is a mosaic of tall shrub patches populated by Salix, Alnus and Betula spp. and extensive taiga patches dominated by P. mariana and B. neoalaskana. The tall shrubs are 1-3 m high. The ground cover is mainly mosses and lichens, with some sedge tussocks. There are also a few patches of low-lying ericaceous shrubs and Betula spp., and a ground cover of Sphagnum mosses and lichens (mostly Cladina and Cetraria spp.). During 2008 and 2009, temperature sensors were installed to $1.25 \mathrm{~m}$ depth and data loggers recorded temperatures at five points: two each in patches of tall shrubs (1-2 m high) and taiga with tall shrubs (1-2.5 m high) (Fig. 4.2c), and one in a patch of low shrubs (0.1-0.4 m high). A thermistor cable was also installed to $14.8 \mathrm{~m}$ depth in an area of tall shrubs in June 2010 (Fig. 4.2d). Drilling encountered $0.5 \mathrm{~m}$ of organic material overlying 14.3 $\mathrm{m}$ of silty sediment with ice lenses.

\subsubsection{Site 4: low shrubs and sedges}

Site 4 is on the extensive plain of the Flats, $43 \mathrm{~km}$ northeast of the village at approximately $305 \mathrm{~m}$ a.s.l. (Fig. 4.1). The area has low shrubs including Betula spp., with Eriophorum tussocks, Sphagnum mosses and lichens. Large thermokarst lakes with rectilinear shorelines dominate the landscape. Patches of tall shrubs including Salix, Alnus and B. glandulosa between 0.5 and $3.0 \mathrm{~m}$ high and small stands of spruce trees (P. mariana) also grow in the area. During 2008 and 2009, 
temperature cables were installed to depths of $14.6 \mathrm{~m}$ in tall shrubs (Fig. 4.2e) and $14.3 \mathrm{~m}$ in low shrubs with sedges (Fig. 4.2f). Drilling encountered a surface layer of 0.3 to $0.5 \mathrm{~m}$ thick organic material overlying $2.5 \mathrm{~m}$ of silty sediment with ice lenses, $6 \mathrm{~m}$ of ice-poor clayey sediment and $5.7 \mathrm{~m}$ of silty sediment with ice lenses.

Temperature sensors attached to miniature data loggers were installed to $1.25 \mathrm{~m}$ depth and recorded temperatures at eleven points: five in low shrubs (0.1-0.25 m high) with sedges, three in tall shrubs (0.5-1 m high) and three in taiga with a tall shrub (0.45-1 m high) understorey.

\subsection{Results}

\subsubsection{Air temperature}

Air temperature was measured in Old Crow and in the Flats at sites 3 and 4 (Fig. 4.1). Old Crow is $55 \mathrm{~m}$ lower than the Flats. Between August 2009 and August 2011, mean air temperature at Old Crow was 1.5 to $1.8^{\circ} \mathrm{C}$ higher than at sites 3 and 4 (Table 4.1). The difference was greater in winter and spring than in summer. At site 4 , the difference in mean daily temperature between Old Crow and site 4 increased to over $4^{\circ} \mathrm{C}$ from mid-May to early June, when the ground was clear of snow but an ice cover persisted on large lakes in the Flats. During this period, air temperature at site 3 was on average $1.7^{\circ} \mathrm{C}$ higher than at site 4 , in association with earlier disappearance of the ice cover from the small lakes near site 3 .

\subsubsection{Snow-pack characteristics and vegetation cover}

Relations between snow and vegetation structure were examined using data from 2010, the most extensive set of annual observations. Snow depth was associated with canopy height in all vegetation types at site 4 and in low and tall shrubs at site 3 (Fig. 4.3a). Snow depth in taiga at site 3 had no clear relation with either tree height or the height of the underlying shrub layer. At site 4, however, snow depth in 


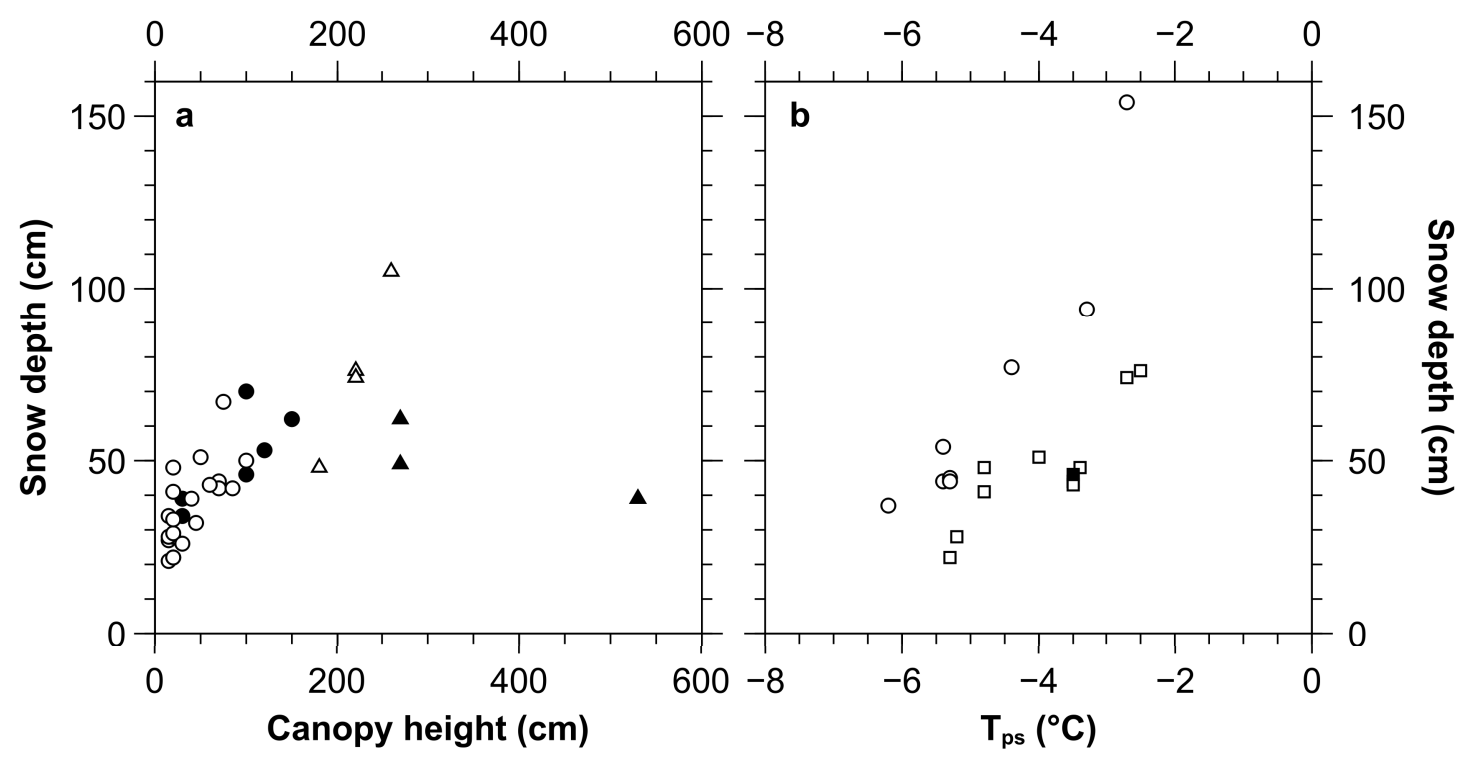

Figure 4.3: (a) Late-winter snow depths measured in 2010 and canopy heights at sites 3 and 4 . Locations with tall and low shrubs are represented by circles (• site 3 ; $\circ$ site 4$)$ and locations with taiga by triangles ( $\boldsymbol{\Delta}$ site $3 ; \Delta$ site 4$)$. The line of best fit, excluding site 3 taiga, is $y=0.24 x+27, r=0.87, p \leq 0.001$. (b) Late-winter snow depths plotted against annual mean near-surface permafrost temperature $\left(T_{p s}\right)$ where data for 2008-09 are represented by circles ( $\bullet$ site 3 ; ० site 4 ) and 2009-10 by squares ( $\square$ site $3 ; \square$ site 4 ). Only one location at site 3 had successful Tps monitoring when snow depths were measured at the site. The line of best fit for 2008-09 was $y=31 x+217, r=0.94, p \leq 0.001$ and for 2009-10 $y=14 x+103$, $r=0.85, p<0.001$. 


\begin{tabular}{ccccc}
\hline & Period & Old Crow & Site 3 & Site 4 \\
\hline \multirow{3}{*}{ AMAT $\left({ }^{\circ} \mathrm{C}\right)$} & $2008-09$ & -9.4 & - & - \\
& $2009-10$ & -6.6 & -8.3 & - \\
& $2010-11$ & -8.8 & -10.3 & -10.6 \\
\hline \multirow{3}{*}{ FDD } & $2008-09$ & 4813 & - & - \\
& $2009-10$ & 4016 & 4462 & 4395 \\
& $2010-11$ & 4514 & 5184 & 5199 \\
\hline \multirow{2}{*}{ TDD } & $2008-09$ & 1366 & - & - \\
& $2009-10$ & 1618 & 1464 & - \\
& $2010-11$ & 1521 & 1414 & 1326 \\
\hline
\end{tabular}

Table 4.1: Annual mean air temperature (AMAT), freezing degree days (FDD) and thawing degree days $(T D D)$ at Old Crow and sites 3 and 4 in Old Crow Flats (Fig. 4.1. Each year begins on September $1^{\text {st }}$. Data for July and August 2010 are missing for site 4 . 
taiga patches was highly correlated with tree height $(r=0.99, p \leq 0.001, n=4)$. As a result, snow depth at site 4 was more variable than at site 3 (Fig. 4.3a).

At site 3, the upper layer of the snow pack in tall shrubs and taiga was soft, with density varying between 0.20 and $0.25 \mathrm{~g} / \mathrm{cm}^{3}$; in low shrubs, the density increased to $0.29 \mathrm{~g} / \mathrm{cm}^{3}$. These layers consisted of comminuted snowflakes resting on unconsolidated layers of faceted grains and depth hoar which constituted between 51 and $75 \%$ (mean $=65 \%, \mathrm{n}=5$ ) of the total snow depth. The average overall density of the snow pack at site 3 was $0.28 \mathrm{~g} / \mathrm{cm}^{3}(\mathrm{n}=5)$, whereas at site 4 it was $0.37 \mathrm{~g} / \mathrm{cm}^{3}(\mathrm{n}=15)$. The upper layer of the snow pack at site 4 was hard and had a density of 0.40 to $0.50 \mathrm{~g} / \mathrm{cm}^{3}$. Depth hoar at site 4 constituted between 16 and $75 \%($ mean $=42 \%, \mathrm{n}=15)$ of the snow pack.

\subsection{3 $T_{p s}$}

At site 3, the dominant land covers are taiga and tall shrubs, whereas site 4 is dominated by low shrubs and sedges. Data recovery was relatively complete at site 4, where $T_{p s}$ was directly associated with snow depth (Fig. 4.3b). $T_{p s}$ for a given snow depth was systematically lower in 2008-09 than in 2009-10 (Fig. 4.3b), reflecting interannual variation in other factors such as air temperature and soil moisture which also influence $T_{p s}$ (Romanovsky and Osterkamp, 1995). Indeed, annual mean air temperature recorded in Old Crow was nearly $3^{\circ} \mathrm{C}$ lower in 2008-09 than in 2009-10, with nearly 800 more freezing degree days in 2008-09 (Table 4.1).

At site 3, data recovery was limited, but the available estimates of $T_{p s}$ suggest that the relative ranking was reversed, as $T_{p s}$ was higher in shrubs than taiga (Table 4.2 ; Fig. 4.4). The lower $T_{p s}$ in shrubs at site 4 than at site 3 was generally associated with a denser and thinner snow pack at the former site (Table 4.2). At site 3 , the one observation from low shrubs and data from tall shrubs present higher $T_{p s}$ values than at taiga sites, where there was less snow.

The highest $T_{p s}$ values were recorded in taiga patches at site 4, where snow, 


\begin{tabular}{cccccccc}
\hline & & \multicolumn{3}{c}{$T_{p s}\left({ }^{\circ} \mathrm{C}\right)$} & & \\
Site & $\begin{array}{c}\text { Lanopy } \\
\text { vegetation }\end{array}$ & $2008-09$ & $2009-10$ & $2010-11$ & $\begin{array}{c}\text { Snow } \\
\text { height } \\
(\mathrm{m})\end{array}$ & $\begin{array}{c}\text { depth } \\
(\mathrm{m})\end{array}$ & $\begin{array}{c}\text { Snow } \\
\text { density } \\
\left(\mathrm{g} \mathrm{cm}^{-3}\right)\end{array}$ \\
\hline \multirow{2}{*}{3} & Taiga & $-4.3(1)$ & - & $-4.1(2)$ & $4.0(2)$ & $0.39(1)$ & $0.27(3)$ \\
& Tall shrubs & $-3.5(2)$ & $-3.5(1)$ & $-3.6(1)$ & $1.3(2)$ & $0.54(2)$ & $0.26(3)$ \\
& Low shrubs & - & - & $-3.2(1)$ & $0.3(1)$ & $0.39(1)$ & $0.32(1)$ \\
& Taiga & $-2.7(1)$ & $-2.9(3)$ & $-2.6(1)$ & $2.0(3)$ & $0.64(3)$ & $0.34(1)$ \\
& Tall shrubs & $-3.9(2)$ & $-3.7(3)$ & $-3.5(2)$ & $0.6(3)$ & $0.39(3)$ & $0.36(2)$ \\
& Low shrubs & $-5.5(5)$ & $-5.0(4)$ & $-4.5(4)$ & $0.2(6)$ & $0.39(5)$ & $0.39(1)$ \\
\hline
\end{tabular}

Table 4.2: $T_{p s}$ between 2008 and 2010 under different vegetation covers. The number of instrument locations included in each average is indicated in parentheses. Snow depth and density, measured in March 2010, are presented from the instrument locations. These snow depth and density values were consistent with data recorded from points along $100 \mathrm{~m}$ transects in each vegetation unit. Tree height was measured at only one of the three taiga locations at site 4 . 

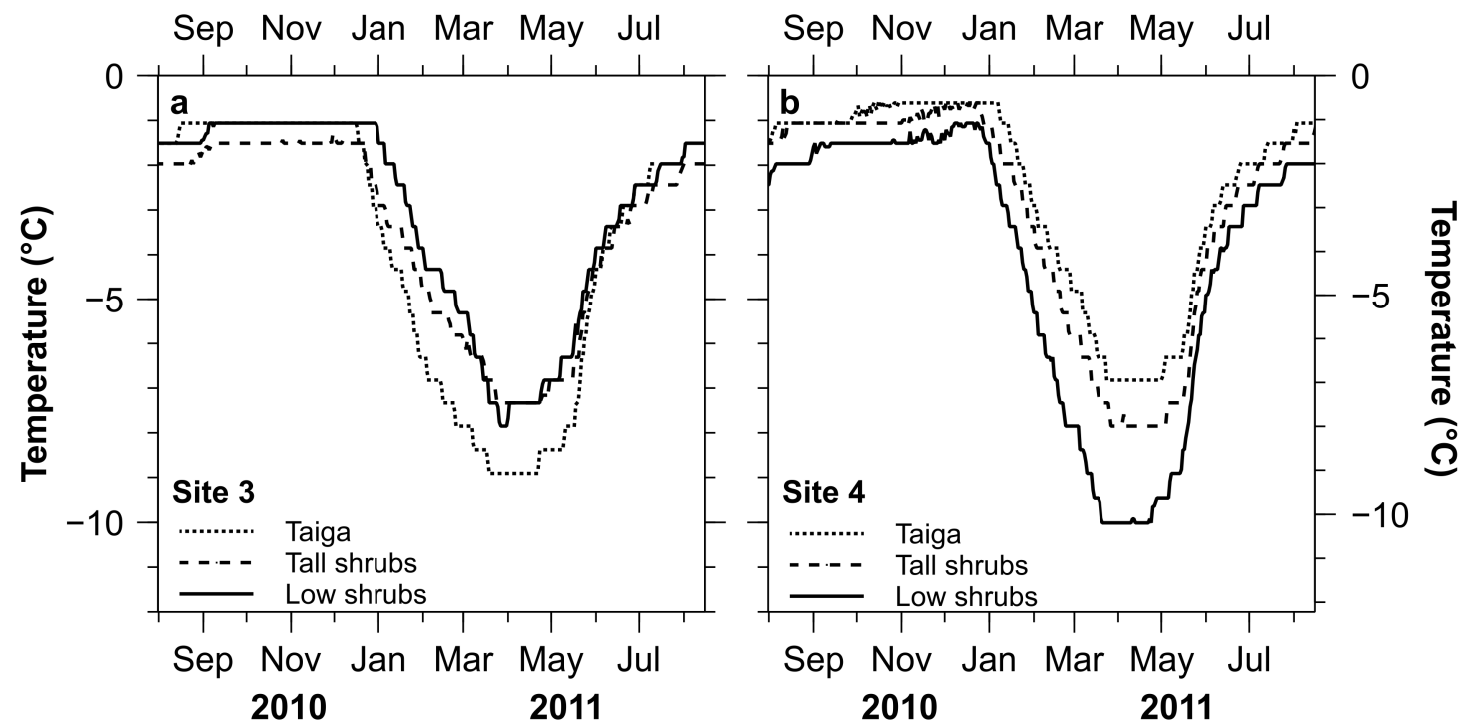

Figure 4.4: Near-surface permafrost temperature (1.25 m depth): (a) at site 3, dominated by tall shrubs and taiga, and (b) at site 4 , dominated by low shrubs and sedges. At site 3, the installation in low shrubs had a $113 \mathrm{~cm}$ thick organic layer and freeze back may have been prolonged by the high moisture content. 
redistributed from lakes and expanses of low shrubs, accumulated in the thickest drifts (Table 4.2). The large lakes and low-lying vegetation at site 4 facilitated snow redistribution by wind, creating contrasts in snow-pack conditions and ground temperatures between areas with varying vegetation structure (Fig. 4.4b). The extensive tall shrub and taiga patches at site 3 impeded snow redistribution by wind. As a result, the snow depth in the middle of a taiga patch at site 3 was less than in the shrubs, and $T_{p s}$ was correspondingly lower. $T_{p s}$ in taiga was approximately $1.5^{\circ} \mathrm{C}$ lower at site 3 than at site 4 (Table 4.2 .

\subsection{4 $T_{g}$ and the annual thermal envelope}

$T_{g}$ measured at the depth of zero annual amplitude is a robust index of permafrost temperature because it varies by less than $0.1^{\circ} \mathrm{C} / \mathrm{a}$. There was no systematic change in $T_{g}$ during the study period, as measurements in 2013 were not consistently higher or lower than the mean at each site. $T_{g}$ in the shrubs at site 4 was lower than at either of the two sites in the taiga (Table 4.3). These data are consistent with the change in $T_{g}$ across the ecotone. The highest $T_{g}$, however, was observed beneath tall shrubs at site 3 , reflecting the deep snow cover at the site and the higher $T_{p s}$ in the shrubs than in taiga there (Table 4.2). Annual mean air temperatures were 1.5 to $1.8^{\circ} \mathrm{C}$ higher at Old Crow than in the Flats (Table 4.1). A similar difference in $T_{g}$ was measured between sites 1 and 4, but not between 1 and 3, due to the influence of the snow pack.

Despite differences in $T_{g}$ within and between sites (Table 4.3), the range of temperature near the surface of permafrost and the depths of zero annual amplitude were similar (Fig. 4.5), indicating similar ground thermal properties at all sites. The cable installed in tall shrubs at site 4 recorded an abrupt narrowing of the thermal envelope between 7.5 and $10 \mathrm{~m}$ depths. 


\begin{tabular}{lcccccc}
\hline Site & $\begin{array}{c}\text { Local } \\
\text { vegetation }\end{array}$ & $\begin{array}{c}\text { Cable } \\
\text { depth } \\
(\mathrm{m})\end{array}$ & $\begin{array}{c}T_{g} 2013 \\
\left({ }^{\circ} \mathrm{C}\right)\end{array}$ & $\begin{array}{c}\text { Mean } T_{g} \\
\left({ }^{\circ} \mathrm{C}\right)\end{array}$ & $\begin{array}{c}\text { Snow } \\
\text { depth } \\
(\mathrm{cm})\end{array}$ & $\begin{array}{c}\text { Snow } \\
\text { density } \\
\left(\mathrm{g} \mathrm{cm}^{\circ}-3\right)\end{array}$ \\
\hline 1 & Taiga-TS & 16.5 & -3.1 & $-3.2(2 \mathrm{yrs})$ & 40 & - \\
2 & Taiga-LS & 20.0 & -4.0 & $-3.8(3 \mathrm{yrs})$ & - & - \\
3 & Tall shrubs & 14.8 & -2.6 & $-2.8(3 \mathrm{yrs})$ & 55 & 0.27 \\
$4 \mathrm{a}$ & Tall shrubs & 14.6 & -4.5 & $-4.6(4 \mathrm{yrs})$ & 46 & 0.34 \\
$4 \mathrm{~b}$ & Low shrubs & 14.3 & -5.1 & $-5.1(4 \mathrm{yrs})$ & 30 & 0.35 \\
\hline
\end{tabular}

Table 4.3: Annual mean ground temperature $\left(T_{g}\right)$ at sites 1 to 4 (2009-13), with snow depths and density measured in March 2010. Snow depth in tall shrubs at site 3 was estimated from a set of snow buttons installed $300 \mathrm{~m}$ from the temperature cable. 


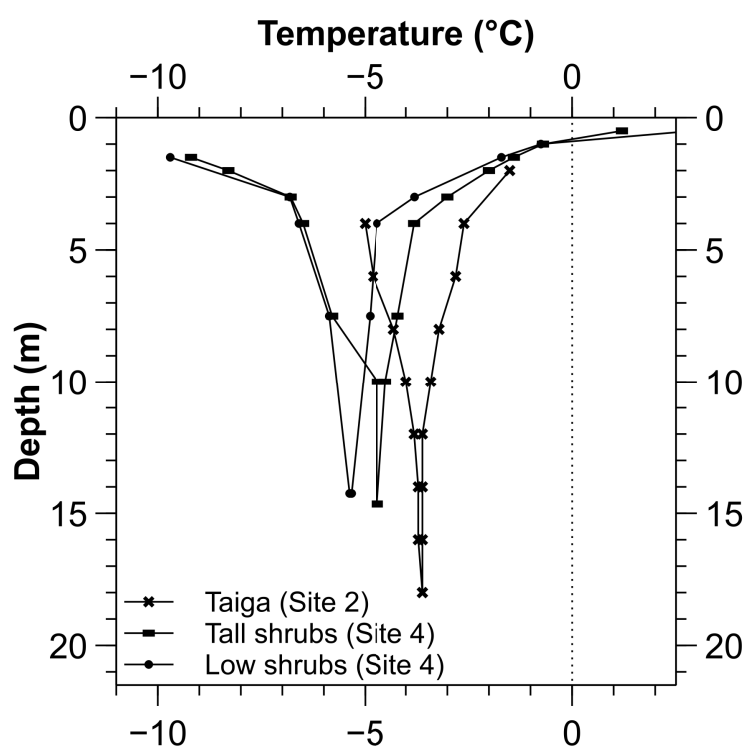

Figure 4.5: Examples of ground temperature envelopes from site 2 (2007-09) and site 4 (2009-10). 


\subsection{Discussion}

In the forest-tundra near Churchill, Manitoba, coniferous trees absorb more solar radiation than snow-covered shrubs in winter and spring, resulting in significant differences in atmospheric heating (Rouse, 1984, Lafleur et al., 1993). Contrary to observations near Churchill or in the Mackenzie Delta (Palmer et al., 2012), air temperature differences between taiga near Old Crow and shrubs in the Flats continued to increase after disappearance of the snow cover, due to sensible cooling by onshore winds blowing off the lake ice.

Our working hypothesis was that, in the patchy vegetation assemblages of the forest-tundra ecotone, ground temperature declines with the height and snow-holding capacity of the vegetation, creating a heterogeneous ground temperature field. Our data indicate that ground temperature, $T_{g}$, generally decreases across treeline from the taiga (e.g. site 1) to the landscapes dominated by low shrubs and sedges (e.g. site 4).

$T_{p s}$ is variable under a heterogeneous vegetation cover, such as at sites 3 and 4. This is consistent with modelled distributions of permafrost temperatures in the forest-tundra ecotone of the Urengoy area, west Siberia (Romanovsky et al., 2010a). At sites 3 and 4 , on the Flats, $T_{p s}$ is correlated to local snow-pack characteristics, similar to the results of Palmer et al. (2012) in the uplands east of the Mackenzie Delta. At site 4, snow depth is correlated with vegetation height as snow supply is not limited by the presence of extensive taiga. The sparse taiga patches of site 4 trapped and accumulated large amounts of snow redistributed by wind, in a similar fashion to isolated patches of taiga surrounded by tundra and lakes in the Slave province, Northwest Territories (Timoney et al., 1992a), and near Churchill, Manitoba Kershaw and McCulloch, 2007). Although snow depth and ground temperatures measured at site 4 are consistent with our working hypothesis, the limited $T_{p s}$ measurements recovered from site 3 show values consistently higher in 
shrubs and lower in taiga. At this site, taiga patches were sufficiently large to limit accumulation and wind-blown snow was trapped at the patch edge. Smith (1975) reported a similar context in the Mackenzie Delta. Patterns of snow accumulation at sites 3 and 4 generally concur with observations by Pomeroy et al. (1995) that the snow load in an area is not only controlled by the snow retention capacity of the local vegetation but is strongly influenced by mesoscale controls on snow supply. Our data suggest that the heterogeneity of the ground temperature field within the forest-tundra ecotone near Old Crow responds to the local vegetation structure and the spatial configuration of land covers at the mesoscale. Hence, $T_{g}$ at site 3 is higher than at any other site.

Permafrost temperatures from sites 1 to 4 are consistent with temperatures reported from the forest-tundra ecotone in the Mackenzie Delta area Burn and Kokelj, 2009), the Hudson Bay Lowlands of northern Manitoba (Smith et al., 2010), and the Kolyma River area in northern Yakutia (Romanovsky et al., 2010b). They are also comparable to temperatures measured across treeline in the Slave province, Northwest Territories Karunaratne, 2011), and in interior Alaska (Smith et al. 2010).

\subsection{Conclusions}

Although vegetation height, snow depth and ground temperatures generally decrease across treeline, our data indicate the variability of snow depths and ground temperatures within the ecotone. The principal results are:

1. Annual mean air temperature at Old Crow was nearly $2^{\circ} \mathrm{C}$ higher than in the Flats. The greatest seasonal departure between the sites was in late spring, when lake ice remained on large lakes in the Flats.

2. Permafrost temperature at the depth of zero annual amplitude was -3.1 to $-4.0^{\circ} \mathrm{C}$ in the taiga along the Porcupine and Old Crow rivers, and varied 
between $-5.1^{\circ} \mathrm{C}$ beneath low shrubs and $-2.6^{\circ} \mathrm{C}$ beneath tall shrubs on the Flats. These temperatures compare with permafrost temperatures measured in or near the forest-tundra ecotone in central and western Canada, Alaska, and eastern Siberia.

3. Heterogeneity of the ground temperature field through the forest-tundra ecotone near Old Crow is controlled by the snow-holding capacity of vegetation at the local scale and the spatial configuration of land covers in the mesoscale landscape, which controls snow supply. 


\title{
Chapter 5
}

\section{Talik development near thermokarst shorelines}

\author{
Modified from the manuscript submitted as:
}

Roy-Léveillée P., Burn C. R. Near-shoreline talik geometry beneath thermokarst lakes of the Old Crow Flats, Yukon. Submitted on May 21 ${ }^{\text {st }}, 2014$ to Journal of Geophysical Research: Earth Surface. Returned for substantial revisions.

\subsection{Introduction}

This chapter presents field observations of permafrost conditions and talik geometry near shorelines of expanding, shallow, thermokarst lakes in tundra of the Old Crow Flats (OCF), northern Yukon (Fig. 5.1). The sensitivity of permafrost degradation rates and talik initiation to variations in the lake-bottom thermal regime are investigated analytically and numerically. Our research aims to improve understanding of talik initiation and development near the shorelines of shallow thermokarst lakes by assessing whether approaches used to predict permafrost degradation beneath lakes of the Mackenzie Delta area and central Yukon Burn and Smith, 1990, Mackay, 1992, Burn, 2002) are effective in OCF, and by investigating inconsistencies via numerical simulation. The specific objectives of the chapter are to: (1) examine thermal conditions near shorelines of thermokarst lakes in OCF; (2) delineate and compare talik geometry near shorelines with varying recession rates, bathymetries, and lake-bottom thermal regimes; (3) compare measured talik profiles with estimates from the Stefan solution based on annual mean lake-bottom temperatures; and (4) assess the sensitivity of permafrost degradation rates beneath shallow water to variations in the lake-bottom thermal 

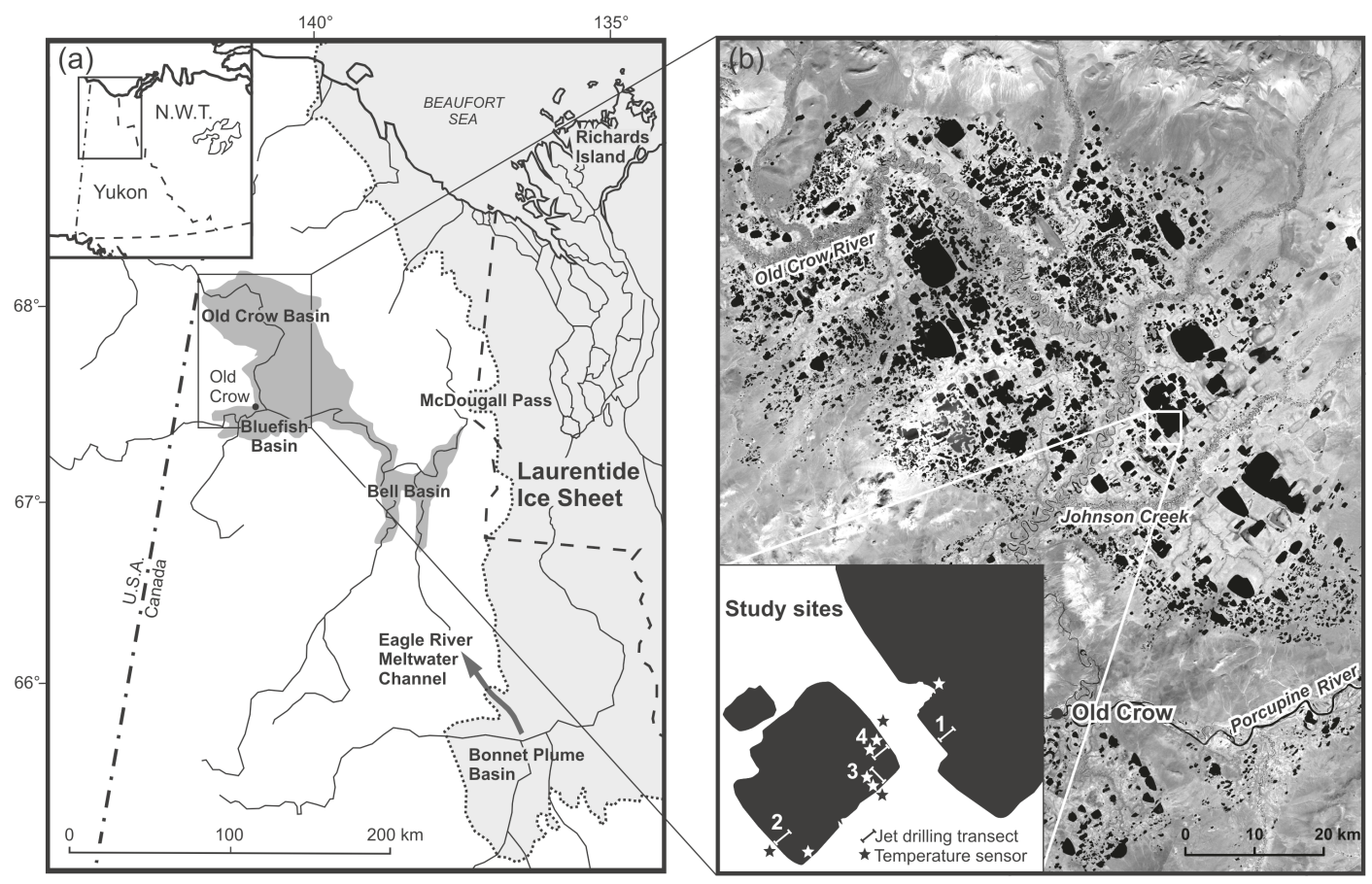

Figure 5.1: (a) Northern Yukon with extent of Glacial Lake Old Crow in the Bell, Bluefish, and Old Crow basins. The approximate maximum limit of the Laurentide Ice Sheet is shown in light grey (after Rampton, 1988, Fig. 55; Zazula et al., 2004, Fig. 1; Kennedy and Froese, 2008, Fig. 2, Lauriol et al., 2009, Fig. 1). (b) Landsat 7 orthoimage of Old Crow Flats and surrounding areas acquired on August 30th 2001 (C)Department of Natural Resources Canada. All rights reserved). Waterbodies are in black, and the location of the study sites is indicated on the inset. 
regime using a numerical model of ground freezing and thawing.

\subsection{Background: thermokarst lake development}

Permafrost is ground that remains at or below $0^{\circ} \mathrm{C}$ for two or more years. Ice-rich permafrost contains a greater volume of ice in the form of, for example, pore ice, segregated ice, and ice wedges than the pore space available in unfrozen ground. If ice-rich permafrost thaws, the ground will subside (Burn, 2013). The pitted relief resulting from thawing of ice-rich permafrost is called thermokarst topography. Thermokarst is initiated when changes in surface or subsurface conditions increase ground temperatures sufficiently to thaw the underlying permafrost Jorgenson, 2013).

Ponding commonly occurs in thermokarst depressions, and accelerates degradation of permafrost by further changing thermal conditions near the ground surface. Once thaw penetration exceeds the depth of seasonal frost penetration beneath the pond, a body of perennially unfrozen ground, or talik, develops Mackay, 1992; Burn, 2013). The enlargement and coalescence of thaw ponds underlain and surrounded by ice-rich ground creates thermokarst lakes Harry and French, 1983; Burn, 1992). At equilibrium, the elevation difference between the original ground surface and the lake bottom reflects the volume of excess ice in the ground that was thawed during talik development Mackay, 1992; West and Plug, 2008).

Many thermokarst lakes in tundra regions have shallow littoral terraces underlain by permafrost that shield ground around the lake from thawing Mackay, 1962; Burn, 2002; Schwamborn et al., 2002; Arp et al., 2011; Hinkel et al., 2012). In contrast, thermokarst lakes without littoral shelves characteristically expand because shorelines are subject to: thermo-mechanical erosion where there is contact between water and permafrost; block failures where banks have been undercut; 
slumping where denuded permafrost is exposed to the air; and thaw subsidence following conduction of heat from the lake into the sediment (Grosse et al., 2013). Rates of lateral expansion vary depending on sediment texture and ground-ice content, lake geometry, bathymetry, water level, and permafrost conditions around the lake Burn, 1992, 2013; Brouchkov et al., 2004). Average expansion rates up to $5.0 \mathrm{~m} \mathrm{a}^{-1}$ have been recorded in the Lower Anadyr Lowlands in Siberia, $2.0 \mathrm{~m} \mathrm{a}^{-1}$ in the Hudson Bay Lowlands and interior Alaska, and $1.2 \mathrm{~m} \mathrm{a}^{-1}$ in central Yukon (Jones et al. 2011). Growth of a thermokarst lake will continue until the surrounding ground ice is exhausted, the lake drains, or the basin becomes infilled by sediment, aquatic plant, or peat growth (Burn, 1992).

At equilibrium, talik boundaries beneath lakes are vertical near the surface Mackay, 1962; Smith, 1976, Burn, 2002). For expanding thermokarst lakes that do not freeze to the bottom, talik depth increases with the square root of time since submergence (Burn and Lewkowicz, 1990, West and Plug, 2008). Several numerical solutions based on mean annual temperature indices have been used to calculate transient ground temperatures near shifting water-land boundaries Hwang and Smith, 1973; Ling and Zhang, 2004, West and Plug, 2008; Kokelj et al., 2009). These models consider cases where water depth exceeds the mean maximum ice thickness. Few models consider permafrost degradation under lakes where the water column freezes to the bottom (Burn, 2002; Ling and Zhang, 2004).

\subsection{Study area}

A description of OCF is presented in Section 2.5 of this thesis. The research presented in this Chapter was conducted in a tundra portion of OCF, where lakes and drained lake basins commonly have rectilinear shorelines and are generally oriented NE-SW or NW-SE (Fig. 5.1) Roy-Léveillée and Burn, 2010). The lakes are surrounded by extensive networks of ice-wedge polygons. Sphagnum spp. 
mosses, cotton-grass (Eriophorum spp.) tussocks, salmonberry (Rubus

chamaemorus) and dwarf birch (Betula glandulosa) generally cover the polygon centres, while ericaceous shrubs, willows (Salix spp.) and alders (Alnus spp.) grow on the dryer ridges at the rims of the polygons. Salix and Alnus bushes up to $3 \mathrm{~m}$ high are also found along some of the lake shores, where the banks are higher than 1 $\mathrm{m}$ and low recession rates permit vegetation development. Permafrost temperatures vary with the snow holding capacity of the vegetation cover in the study area. Near the depth of zero annual amplitude, more than $14 \mathrm{~m}$ below the surface, mean ground temperatures measured in $2009-2013$ were $-5.1^{\circ} \mathrm{C}$ in low shrub $(\leq 0.6 \mathrm{~m}$ high) polygonal tundra and $-4.6^{\circ} \mathrm{C}$ where tall shrubs ( $\geq 1 \mathrm{~m}$ high) grow on ice-wedge ridges Roy-Léveillée et al. 2014). Peat thickness in OCF varies between 0.3 and 1.0 $\mathrm{m}$ and the dates on basal peat samples range from 350 to $3300{ }^{14} \mathrm{C}$ a $\mathrm{BP}$ Ovenden, 1985). Basal peat collected at $0.8 \mathrm{~m}$ depth at the study site was dated at $2175 \pm 20$ ${ }^{14} \mathrm{C}$ a BP (UCIAMS \# 67161) (D.G. Froese, personal communication 2009).

\subsection{Methods}

\subsubsection{Field methods}

In 2008, four study sites were identified on adjacent lakes representing a range of shoreline conditions (Fig. 5.1; Table 5.1). Low-shrub polygonal tundra surrounded sites 1 and 2 whereas tall shrubs characterized sites 3 and 4 . At the latter sites, shrub abundance increased at the bank top, and shrubby vegetation extended to the waterline (Fig. 5.2).

In spring of 2009 and 2010, lake ice was used as a drilling platform to delineate the base of the sub-lake talik along four lines perpendicular to shore, one at each site. Holes were augered in the ice at 10-m intervals to measure lake depths. Since bulk ice thaws at $0^{\circ} \mathrm{C}$, talik depth was estimated in the same holes by sudden resistance to penetration of a water-jet drill (Burn and Smith, 1990; Burn, 2002). 

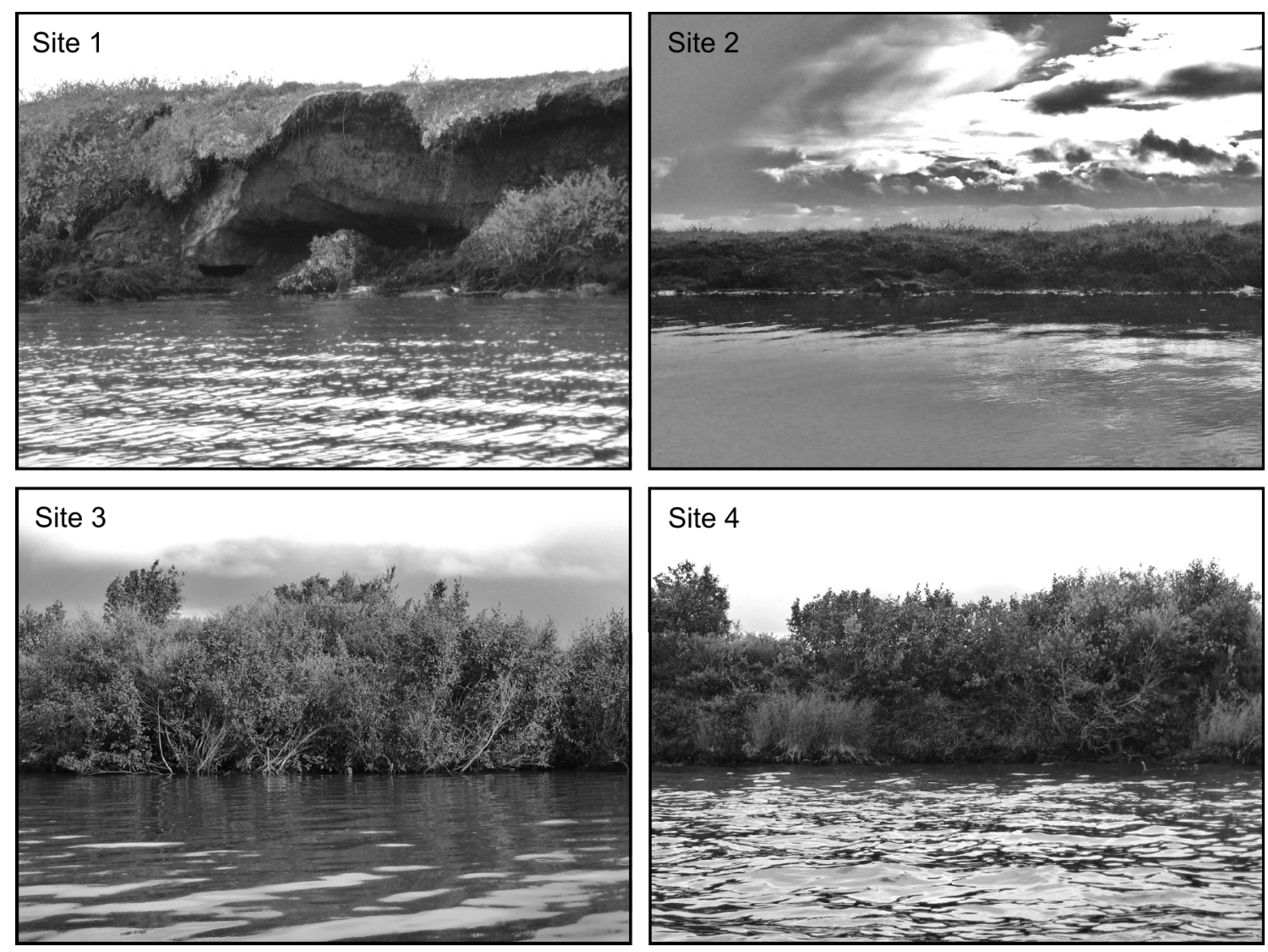

Figure 5.2: The four shorelines from which transects were extended over lake ice to measure snow depth, lake depth, lake-bottom temperature, and talik depth. Bank heights for sites 1 to 4 were $3.0 \mathrm{~m}, 1.0 \mathrm{~m}, 2.6 \mathrm{~m}$, and $2.0 \mathrm{~m}$, respectively. 


\begin{tabular}{|c|c|c|c|c|c|c|}
\hline Site & $\begin{array}{l}\text { Aspect, } \\
\text { fetch } \\
(\mathrm{m})\end{array}$ & $\begin{array}{c}\text { Bank } \\
\text { height } \\
(\mathrm{m})\end{array}$ & $\begin{array}{c}\text { Bank } \\
\text { slope } \\
\left({ }^{\circ}\right)\end{array}$ & $\begin{array}{l}\text { Water } \\
\text { depth } \\
(\mathrm{m})\end{array}$ & $\begin{array}{l}\text { Bank slope } \\
\text { vegetation }\end{array}$ & $\begin{array}{c}\text { Bank top } \\
\text { vegetation }\end{array}$ \\
\hline 1 & $\begin{array}{l}\text { NE, } \\
4000\end{array}$ & 3.0 & $35-90$ & 2.2 & $\begin{array}{l}\text { Exposed soil, } \\
\text { overhanging } \\
\text { peat curtains }\end{array}$ & $\begin{array}{c}\text { Low shrub } \\
\text { tundra }\end{array}$ \\
\hline 2 & $\begin{array}{l}\mathrm{NE}, \\
1600\end{array}$ & 1.0 & 35 & 2.3 & Exposed soil & $\begin{array}{c}\text { Low shrub } \\
\text { tundra }\end{array}$ \\
\hline 3 & $\begin{array}{l}\text { NW, } \\
1200\end{array}$ & 2.6 & 35 & 1.4 & Tall shrubs & $\begin{array}{c}\text { Tall shrub } \\
\text { tundra }\end{array}$ \\
\hline 4 & $\begin{array}{l}\text { SW, } \\
1600\end{array}$ & 2.0 & 30 & 0.4 & Tall shrubs & $\begin{array}{c}\text { Tall shrub } \\
\text { tundra }\end{array}$ \\
\hline
\end{tabular}

Table 5.1: Lakeshore morphology, vegetation cover, and water depth $40 \mathrm{~m}$ from shore at the four study sites. The bank slope near site 1 varied during each openwater season depending on rates of thermo-denudation and sediment removal by wave erosion. 
Near-shore lake-bottom temperatures were monitored and recorded every four hours from August 2008 to August 2011 by Onset HOBO H8 data loggers (factory specified time accuracy: +45 to -60 minutes per year at $0^{\circ} \mathrm{C}$; range of internal temperature sensor: $-40^{\circ} \mathrm{C}$ to $100^{\circ} \mathrm{C}$, accuracy: $\pm 0.7^{\circ} \mathrm{C}$ and resolution: $\pm 0.4^{\circ} \mathrm{C}$ at $0^{\circ} \mathrm{C}$ ) placed in waterproof capsules that were attached to the shore with steel line and anchored to the lake bottom (Fig. 5.1). In late winter 2009 and 2010, snow depth and ice thickness were measured at each data-logger location, and in several locations near the centre of the lakes, where ice did not reach the lake bottom, to assess maximum lake-ice thickness. Temperature near the top of permafrost was recorded from August 2008 to August 2011 in undisturbed ground within $50 \mathrm{~m}$ of the lake shore (Fig. 5.1). Temperature sensors (Onset Corp. TMC6-HA, range: $-40^{\circ} \mathrm{C}$ to $100^{\circ} \mathrm{C}$, accuracy: $\pm 0.5^{\circ} \mathrm{C}$ and resolution: $\pm 0.4^{\circ} \mathrm{C}$ at $0^{\circ} \mathrm{C}$ ) were installed 1.25 m below the ground surface and connected to HOBO H8 data loggers to record ground temperature every 4 hours. A HOBO H8 data logger and TMC6-HA temperature sensor were also used to measure air temperature $1.5 \mathrm{~m}$ above the ground in a radiation shelter between sites 1 and 4 from August 2009 to September 2011. We did not calibrate the data loggers and sensors used in Old Crow Flats, but calibration of a large number of similar loggers and sensors gave results consistent with the factory specifications, and no bias was found in the measurements Karunaratne, 2011; Ensom et al., 2012).

Two sets of permafrost core samples extending to a depth of $1.5 \mathrm{~m}$ were extracted with a CRREL drill from the bank top near each site. During late winter 2010, two additional sets of core samples were extracted from the lake bottom near the foot of a rapidly receding shore bank at site 1 . The latter two sets included refrozen active-layer and permafrost, and their upper sections were examined to identify and eliminate bank debris and reworked lake sediment based on organic contents and breaks in cryostratigraphic structure. 


\subsubsection{Ground material properties}

Core sections were thawed, mixed, poured into beakers, weighed, and allowed to settle (Kokelj and Burn, 2003). Volumes of saturated sediment $\left(V_{s s}\right)$ and supernatant water $\left(V_{s w}\right)$ were recorded to provide a conservative estimate of the volumetric excess ice content $\left(I_{v} \%\right)$ of the samples using eq. 5.1 (Table 5.2 Kokelj and Burn, 2003). Notation for all calculations is given in the List of abbreviations and symbols. The equations used in this chapter are presented in Table 5.2. Total water contents were determined by oven drying the sediments at $105^{\circ} \mathrm{C}$. Organic contents of the cores were estimated by loss on ignition at $550^{\circ} \mathrm{C}$ and sediment textures of these cores were determined by the pipette method (Sheldrick, 1984). The thermal conductivities of thawed and frozen sediments $(\lambda)$ were calculated using a geometric mean (eq. 5.2, Table 5.2) (Johansen, 1977). Thermal conductivities of $0.56,2.24,0.25$, and $2.92 \mathrm{~W} \mathrm{~m}^{-1{ }^{\circ}} \mathrm{C}^{-1}$ were used for the water $\left(\lambda_{w}\right)$, ice $\left(\lambda_{i}\right)$, organic $\left(\lambda_{o}\right)$, and mineral $\left(\lambda_{m}\right)$ components, respectively (Williams and Smith, 1989). The volumetric organic content $\left(O_{v}, \%\right)$ was estimated using the average organic gravimetric fraction $\left(O_{g}\right)$ obtained from loss on ignition, and assuming densities of $1.30 \times 10^{6} \mathrm{~g} \mathrm{~m}^{-3}$ for organic matter and $2.65 \times 10^{6} \mathrm{~g} \mathrm{~m}^{-3}$ for the mineral fraction (Williams and Smith, 1989). Volumetric heat capacities for thawed and frozen ground were calculated using a weighted arithmetic mean (eq.5.2, Table 5.2 where heat capacities of 4180, 1296, 2385, $2496 \mathrm{~kJ} \mathrm{~m}^{-3}{ }^{\circ} \mathrm{C}^{-1}$ were used for the water, ice, mineral, and dry organic components, respectively (Williams and Smith, 1989).

\subsubsection{Determination of shore recession rates}

Shore-bank recession was monitored using benchmarks installed near each study line during the 2009, 2010, and 2011 open-water seasons. Calculated uncertainty in short-term erosion rates was based on the precision of measurements at each site, depended on the abruptness of the break in slope marking the top of the bank, and 
Calculations of ground thermal properties

$$
\begin{aligned}
& I_{v}=\left[\frac{1.09 V_{s w}}{V_{s s}+\left(1.09 V_{s w}\right)}\right] 100 \\
& \lambda_{f}=\left(\lambda_{w}^{u \% p}\right)\left(\lambda_{i}^{I_{v}+\left(1-u_{\%}\right) p}\right)\left(\lambda_{o}^{V_{o}}\right)\left(\lambda_{m}^{V_{m}}\right) \\
& \begin{array}{cc}
C_{f}=\left[C_{m} V_{m}+C_{o} V_{o}+C_{i}\left(I_{v}+\left(1-u_{\%}\right) p\right)+C_{w} p u_{\%}\right] \quad \text { Williams and } \\
\quad \text { Smith, 1989) }
\end{array}
\end{aligned}
$$

The Stefan solution

$$
z(t)=\left\{\begin{array}{lcc}
\sqrt{\frac{2 \lambda_{t} T_{l b 1} t}{L}} & & \text { Sirn and } \\
\sqrt{\frac{2 \lambda_{t}}{L}\left(T_{l b 2} t-T_{l b 2} t_{t r}+T_{l b 1} t_{t r}\right)} & \text { for } \mathbf{t} \geq \mathbf{t}_{\mathrm{tr}} & \text { Smith, } 1990) \\
\end{array}\right.
$$

Temp/W: Numerical model of thaw penetration

$$
\begin{gathered}
C_{a}=C+L \theta \frac{\partial \theta_{u}}{\partial T} \\
\frac{\partial}{\partial x}\left(\lambda_{x} \frac{\partial T}{\partial x}\right)+\frac{\partial}{\partial y}\left(\lambda_{y} \frac{\partial T}{\partial y}\right)+Q=C_{a} \frac{\partial T}{\partial t} \\
{[K]\{T\}+[M]\{T\}, t=\{Q\}} \\
(\Delta t[K]+[M])\left\{T_{1}\right\}=\Delta t\left\{Q_{1}\right\}+[M]-\left\{T_{0}\right\} \\
{[K]=\tau \sum_{j=1}^{n}\left[B_{j}\right]^{T}\left[\lambda_{j}\right] \operatorname{det}\left|J_{j}\right| W_{1 j} W_{2 j}} \\
{[M]=\tau \sum_{j=1}^{n} C_{a}<N>^{T}<N>\operatorname{det}\left|J_{j}\right| W_{1 j} W_{2 j}} \\
\{Q\}=q \tau \int_{L}<N>^{T} \partial S \\
w_{u}=6.0|T|^{-0.301}
\end{gathered}
$$$$
\text { Ltd, 2010) }
$$$$
\text { Andersland and }
$$$$
\text { Ladanyi, 2003, }
$$$$
\text { Table 2.6) }
$$

Table 5.2: List of equations used in Chapter 5. Notation is presented on pages xxvi to xxviii, in the List of abbreviations and symbols. 
ranged between \pm 0.05 and $\pm 0.3 \mathrm{~m}$. Rates of shore recession measured in the field were compared to long-term recession rates determined from aerial photographs of the study sites taken in 1951 and 1996. The scanned photographs were superimposed using ice-wedge networks near the four sites to co-register the images. Uncertainty in shoreline location was assessed based on picture quality and resolution as well as bank characteristics, and ranged between \pm 0.6 and $\pm 1.9 \mathrm{~m}$.

\subsubsection{Analytical model of thaw penetration}

Measured talik depths near the four shorelines were compared to thaw depths predicted using the Stefan solution (eq. 5.4, Table 5.2). This equation has been used to model thaw penetration under expanding lakes in central Yukon, providing results consistent with field observations (Burn and Smith, 1990). It computes thaw depth based on time since submergence, annual mean lake-bottom temperature, thermal conductivity of the thawed ground, and volumetric latent heat of fusion. The application assumes: (1) that thermokarst lake expansion causes a step change in surface temperature; (2) that all thawing takes place at $0^{\circ} \mathrm{C} ;(3)$ that ground thermal properties are homogeneous; and (4) that the permafrost beneath the lake is uniformly at $0^{\circ} \mathrm{C}$ prior to thawing. Departure from these assumptions for lakes of the OCF may be greatest for (1) if progressive subsidence changes lake-bottom temperatures after submergence. The Stefan solution is generally a robust model of ground freezing and thawing under a wide range of conditions, because the volumetric latent heat of fusion is at least one order of magnitude higher than the sensible heat components of the system Mackay, 1962, 1973, Burn and Smith, 1990). All parameters used in the simulation of talik development with the Stefan solution are presented in Table 5.3. Ground thermal properties were estimated based on samples from the two sets of lake-bottom core samples extracted at site 1 (Table 5.4. The average shore recession rate for 1951 to 1996 was used to calculate time since submergence for points in the lake bed. 


\section{Stefan solution}

\section{Ground properties}

Porosity $\left(\mathrm{m}^{3} \mathrm{~m}^{-3}\right) \quad 0.49( \pm 0.1)$

Dry soil organic fraction $\left(\mathrm{g} \mathrm{g}^{-1}\right) \quad 0.06( \pm 0.03)$

Vol. latent heat $\left(\mathrm{kJ} \mathrm{m}^{-3}\right) \quad 1.5 \times 10^{5}( \pm 0.3)$

Thawed thermal conductivity $\left(\mathrm{W} \mathrm{m} \mathrm{m}^{-1 \circ} \mathrm{C}^{-1}\right)$

$1.12( \pm 0.3)$

Site specific parameters

$\begin{array}{llll}\text { Site } 1 & \text { Site } 2 & \text { Site } 3 & \text { Site } 4\end{array}$

$\begin{array}{ccccc}\text { Shore recession rate }\left(\mathrm{m} \mathrm{a}^{-1}\right) & 2.0 & 0.9 & 0.3 & 0.1 \\ ( \pm 0.3) & ( \pm 0.3) & ( \pm 0.2) & ( \pm 0.3)\end{array}$

\begin{tabular}{|c|c|}
\hline \multicolumn{2}{|c|}{ Numerical simulations with Temp/W } \\
\hline $\begin{array}{l}\text { Ground properties } \\
\text { Porosity }\left(\mathrm{m}^{3} \mathrm{~m}^{-3}\right)\end{array}$ & 0.49 \\
\hline Vol. excess ice (\%) & 0 \\
\hline Vol. latent heat $\left(\mathrm{kJ} \mathrm{m}^{-3}\right)$ & $1.5 \times 10^{5}$ \\
\hline $\begin{array}{l}\text { Thawed vol. heat capacity } \\
\left(\mathrm{kJ} \mathrm{m} \mathrm{m}^{-3}{ }^{\circ} \mathrm{C}^{-1}\right)\end{array}$ & 3270 \\
\hline $\begin{array}{l}\text { Frozen vol. heat capacity } \\
\left(\mathrm{kJ} \mathrm{m}{ }^{-3}{ }^{\circ} \mathrm{C}^{-1}\right)\end{array}$ & 2170 \\
\hline $\begin{array}{l}\text { Thawed thermal conductivity } \\
\left(\mathrm{W} \mathrm{m} \mathrm{m}^{-1}{ }^{\circ} \mathrm{C}^{-1}\right)\end{array}$ & 1.12 \\
\hline $\begin{array}{l}\text { Frozen thermal conductivity } \\
\left(\mathrm{W} \mathrm{m} \mathrm{m}^{-1}{ }^{\circ} \mathrm{C}^{-1}\right)\end{array}$ & 2.20 \\
\hline $\begin{array}{l}\text { Geothermal heat flow } \\
\left(\mathrm{W} \mathrm{m}^{-1}\right)\end{array}$ & 0.07 \\
\hline
\end{tabular}

Table 5.3: Ground properties and boundary conditions used for analytical and numerical simulations of talik development. 


\begin{tabular}{llrllllll}
\hline $\begin{array}{l}\text { Depth below } \\
\text { bank top } \\
(\mathrm{m})\end{array}$ & $\begin{array}{l}\text { Depth below } \\
\text { top of bore hole } \\
(\mathrm{m})\end{array}$ & $\begin{array}{l}\text { Vol. moisture } \\
\text { content } \\
(\%)\end{array}$ & $\begin{array}{l}\text { Vol. excess- } \\
\text { ice content } \\
(\%)\end{array}$ & $\begin{array}{l}\text { Grav. organic } \\
\text { content } \\
(\%)\end{array}$ \\
\hline $3.3-3.5$ & $0.8-1.0$ & $0.9-1.1$ & 45 & 54 & 0 & 0 & 10 & 6 \\
$3.5-3.7$ & $1.0-1.2$ & $1.1-1.3$ & 60 & & 9 & 0 & & 6 \\
$3.7-3.9$ & $1.2-1.4$ & $1.3-1.5$ & 51 & 58 & 0 & 0 & 7 & 3 \\
$3.9-4.1$ & $1.4-1.6$ & & 54 & & 0 & 0 & 8 & \\
$4.1-4.3$ & $1.6-1.8$ & & 39 & & 0 & 0 & 6 & \\
$4.3-4.5$ & $1.8-2.0$ & & 50 & & 0 & 0 & 4 & \\
$4.5-4.7$ & $2.0-2.2$ & 40 & & 0 & 0 & 5 & \\
\hline
\end{tabular}

Table 5.4: Porosity, excess ice, and organic matter content in samples from two lakebottom permafrost cores extracted near a rapidly receding shoreline. The cores were collected in collected in May 2010. The height of the adjacent shore bank was 2.5 m. Material between 2.5 and $3.3 \mathrm{~m}$ beneath the top of the bank was not sampled to avoid fallen material. 
One set of talik-depth estimates was based on mean annual lake-bottom temperatures measured where ice did not reach the lake bottom $\left(4.5^{\circ} \mathrm{C}\right)$. A second set of estimates was initiated under conditions where ice reached the lake bottom and the mean annual temperature was $2^{\circ} \mathrm{C}$, but subsequently continued with the value of $4.5^{\circ} \mathrm{C}$ once lake depth exceeded the maximum lake-ice thickness (eq. 5.5, Table 5.2). The time in years between initiation and transition to a higher lake-bottom temperature $\left(t_{t r}\right)$ was determined from the extent of seasonally frozen lake-bottom sediment observed during jet-drilling and shore recession rates.

An uncertainty range was calculated for each set of talik-depth estimates. Maximum depths were based on minimum values for rates of shore recession and ground moisture content, and maximum values for thermal conductivity of thawed ground. Minimum talik depths were based on maximum values for rates of shore recession and moisture content, and minimum values for thermal conductivity of thawed ground.

\subsubsection{Numerical simulations}

Models that use mean annual temperatures to define surface conditions do not include characteristics of the thermal regime such as the duration of freezing and thawing at the lake bottom. Three numerical experiments were used to investigate how variation in the lake-bottom thermal regime may affect talik initiation, development rate, and refreezing under conditions similar to the study sites.

Thaw front penetration in the lake-bottom sediment was modelled with Temp/W (Release 7.03, GEO-SLOPE International Ltd.), a commercially available package that calculates finite element numerical solutions for conductive heat-transfer problems. It accounts for temperature-dependent thermal properties such as volumetric unfrozen water content and latent heat effects associated with phase change through an apparent heat capacity (eq. 5.3 and 5.6, Table 5.2. Temp/W applies the Galerkin method of weighed residuals to its governing 
differential equation (eq. 5.7, Table 5.2 to derive the general finite element equation for two-dimensional analysis (eq. 5.8, Table 5.2 GEO-SLOPE International Ltd, 2010). It performs time integration using a finite difference approximation scheme simplified using the backwards difference method (eq. 5.9, Table 5.2), and uses Gaussian numerical integration to evaluate the element characteristic matrix (eq. 5.10, Table 5.2) and the heat matrix (eq. 5.11, Table 5.2). The nodal flux boundary vector is defined by Equation 5.12 (Table 5.2 GEO-SLOPE International Ltd, 2010). Temp/W has been used in several permafrost studies Arne and Anisimov, 2008, Darrow, 2011; Dyke and Sladen, 2010; Stevens et al., 2010, including studies of talik development beneath lakes in the Mackenzie Delta region at time scales varying from decades to several thousand years (Taylor et al., 2008; Kokelj et al. 2009).

Thaw front penetration and thermal conditions beneath the lake bottom were simulated in one dimension, over a depth of $100 \mathrm{~m}$. The simulation domain was discretized with a vertical spacing of $0.01 \mathrm{~m}$ in the upper metre, $0.05 \mathrm{~m}$ to a depth of $5 \mathrm{~m}, 0.1 \mathrm{~m}$ to a depth of $10 \mathrm{~m}, 0.5 \mathrm{~m}$ to a depth of $50 \mathrm{~m}$, and $1 \mathrm{~m}$ to a depth of $100 \mathrm{~m}$. Thermal properties of the ground material were based on lake-bottom core samples (Tables 5.3, 5.4. The thawing characteristic curve was a function typical for silt loam, the grain size of the soil found at the study sites, calculated using parameters presented by Andersland and Ladanyi 2003, Table 2.6) based on Smith and Tice (1988, Appendix A) (Table 5.2, eq. 5.13). The transition between $\lambda_{f}$ and $\lambda_{t}$ was specified based on this thawing characteristic curve and eq. 5.2 (Table 5.2). A geothermal heat flux of $0.07 \mathrm{~W} / \mathrm{m}^{2}$ was used as the lower boundary condition Blackwell and Richards, 2004). The upper boundary represented thermal conditions near the ground surface either at the top of permafrost, when simulating subaerial conditions prior to submergence, or at the lake bottom, when simulating talik development after submergence.

Simulated conditions prior to submergence and talik development were based 
on the surface history of the study area inferred from a basal peat date of $2175 \pm 20$

${ }^{14}$ C years BP (UCIAMS \# 67161) (D.G. Froese, personal communication 2009)

collected near site 2. Steady-state equilibrium conditions with $T_{l b}=4.5^{\circ} \mathrm{C}$, as under a large lake, were followed by 2000 years of subaerial conditions with a temperature at the permafrost surface $\left(T_{p s}\right)$ of $-4.0{ }^{\circ} \mathrm{C}$. Simulations of talik development began from that point. Unless otherwise specified, daily time steps were used with daily mean lake-bottom temperatures as the upper boundary condition. Progress of the thawing or freezing front was extracted every year during late spring when mean daily lake-bottom temperature first reached $0^{\circ} \mathrm{C}$, to assess whether a talik had begun to develop or how far it extended below the lake bottom. The talik boundary was defined as the $-0.005^{\circ} \mathrm{C}$ isotherm, to avoid including ground that was isothermal slightly below $0^{\circ} \mathrm{C}$. This ensured that freezing had really begun where ground cooling and refreezing occurred, and had very little influence on talik depth in simulations which did not involve talik refreezing.

\section{Talik initiation and interannual variations in $T_{l b}$}

Since freezing and thawing are not included in models that use $T_{l b}$ values to define upper boundary conditions, a finer temporal resolution for lake-bottom temperature is required to resolve whether freeze-back of the thawed layer occurs in the years following submergence and whether a talik will become established.

A first numerical experiment examined the effects on talik initiation and development of interannual variations in lake-bottom thermal regime after submergence. Upper boundary conditions were defined with mean daily temperatures recorded at site 2, $16 \mathrm{~m}$ from the shore. Temperatures recorded in 2009-10 $\left(T_{l b}=1.9^{\circ} \mathrm{C}\right)$ were cycled at the surface, with annual records from 2010-11 $\left(T_{l b}=3.3^{\circ} \mathrm{C}\right)$, when lake-bottom conditions were warmer, inserted at regular intervals. Four thermal environments were simulated: (1) 2009-10 data alone as a base case; (2) 2010-11 inserted every third year; (3) 2010-11 inserted every second 
year; and (4) 2010-11 data alone.

\section{Talik development rate and thermal amplitude}

Where the water column freezes through, the amplitude of the annual thermal regime and the ratio of freezing to thawing degree days at the lake bottom $(F D D / T D D)$ can vary without affecting $T_{l b}$. A second numerical experiment examined the sensitivity of talik development rates to variation in $F D D / T D D$. Upper boundary conditions were defined using a range of thermal regimes characterized by a $T_{l b}$ of $2.00^{\circ} \mathrm{C}, 252$ days of ice contact with the lake bottom, and $F D D / T D D$ ranging from 0.01 to 0.45 . The simulations were conducted over 100 years.

\section{Talik refreezing with $T_{l b}$ above $0^{\circ} \mathrm{C}$}

Talik refreezing may affect talik development and geometry near receding shores where water is shallow and frost penetrates the lake bottom. A third numerical experiment investigated whether talik refreezing may occur under thermal conditions observed in OCF during our study. To assess this, the development of a talik $6.9 \mathrm{~m}$ deep was simulated by applying a $T_{l b}$ of $2.4^{\circ} \mathrm{C}$ for 57 years after spin-up, and talik development was examined over the following 100 years using six different upper boundary conditions. Five of these conditions used mean daily temperatures and one was based on a mean annual lake-bottom temperature. These upper boundary conditions were defined with mean daily lake-bottom temperatures recorded (1) $6 \mathrm{~m}$ from shore at site 2 in 2009-10 $\left(T_{l b}=1.5^{\circ} \mathrm{C}, F D D / T D D=0.60\right)$; (2) $16 \mathrm{~m}$ from shore at site 2 in 2009-10 $\left(T_{l b}=1.9^{\circ} \mathrm{C}, F D D / T D D=0.51\right)$; (3) $20 \mathrm{~m}$ from shore at site 3 in 2009-10 $\left(T_{l b}=1.4^{\circ} \mathrm{C}, F D D / T D D=0.65\right)$; (4) $15 \mathrm{~m}$ from shore at site 4 in 2010-11 $\left(T_{l b}=2.4^{\circ} \mathrm{C}, F D D / T D D=0.37\right)$; (5) $35 \mathrm{~m}$ from shore at site 4 in $2010-11\left(T_{l b}=2.2^{\circ} \mathrm{C}, F D D / T D D=0.44\right)$; and (6) the mean annual lake-bottom temperature recorded $20 \mathrm{~m}$ from shore at site 3 in $2009-10\left(T_{l b}=1.4^{\circ} \mathrm{C}\right.$, 
$F D D / T D D=0)$

\subsection{Field results}

\subsubsection{Climate data}

The relation between daily mean air temperatures in the study area and at Old Crow between June 2009 and August 2011 had a slope of 1.0, but air temperatures at the study area were $2.3^{\circ} \mathrm{C}$ lower than at Old Crow $(\mathrm{r}=0.99, \mathrm{p}<0.001)$. Annual mean air temperature, calculated as the average of daily mean temperatures between September $1^{\text {st }}$ and August $31^{\text {st }}$, varied between -9.4 and $-6.5^{\circ} \mathrm{C}$ from 2008 to 2011 at Old Crow (Table 5.5). The warmest year was 2009-10, due to high temperatures from February to May, and the coldest was 2008-09, due to low temperatures in fall and winter. Summer air temperatures were similar each year. Precipitation was higher than normal in 2010-11, particularly in February (155 mm) and June (162 mm).

\subsubsection{Permafrost conditions}

Annual mean temperatures at the top of permafrost were approximately $1^{\circ} \mathrm{C}$ lower in the low shrubs near site 2 than in the tall shrubs of sites 3 and 4 (Table 5.6), where drifting snow may be trapped to create a thick snow pack, as in 2008-09 (Roy-Léveillée et al., 2014). Estimates of volumetric segregated and pore-ice content $\left(I_{c}\right)$ in the top metre of permafrost ranged between $14 \%$ and $31 \%$ with a mean of $22 \%$, and ice-rich ground was observed approximately $1 \mathrm{~m}$ below the surface at all sites. Well-developed ice wedge networks were present near the four sites, and extended to depths of 2 to $3 \mathrm{~m}$ in the bank exposure near site 1 . Analysis of the core samples extracted from the foot of the rapidly receding bank near site 1 indicated that segregated ice content is also reduced below $3 \mathrm{~m}$ depth (Table 5.4). The average moisture content in the lake-bottom samples was $49 \%$. The samples were silt loams 


\begin{tabular}{lccc}
\hline & $2008-09$ & $2009-10$ & $2010-11$ \\
\hline AMAT $\left({ }^{\circ} \mathrm{C}\right)$ & -9.4 & -6.5 & -8.3 \\
$F D D$ & 4813 & 4016 & 4540 \\
$F D D$ before Dec. 1 & 1016 & 942 & 766 \\
Total precipitation $(\mathrm{mm})$ & 352 & 344 & 721 \\
\hline
\end{tabular}

Table 5.5: Annual mean air temperature (AMAT), freezing degree days (FDD) and precipitation at Old Crow from September $1^{\text {st }}$ to August $31^{\text {st }}, 2008-11$ 


\begin{tabular}{lccccc}
\hline \multirow{2}{*}{ Site } & $T_{p s}\left({ }^{\circ} \mathrm{C}\right)$ & $\begin{array}{c}\text { Snow depth }(\mathrm{m}) \\
\text { March 2009 }\end{array}$ & $\begin{array}{c}T_{p s}\left({ }^{\circ} \mathrm{C}\right) \\
2009-10\end{array}$ & $\begin{array}{c}\text { Snow depth }(\mathrm{m}) \\
\text { March 2010 }\end{array}$ & $\begin{array}{c}T_{p s}\left({ }^{\circ} \mathrm{C}\right) \\
2010-11\end{array}$ \\
\hline 2 & -5.4 & 0.34 & -4.8 & 0.37 & -4.0 \\
3 & -3.3 & 0.77 & -3.5 & 0.44 & -3.2 \\
4 & -4.4 & 0.75 & -4.0 & 0.37 & -3.5 \\
\hline
\end{tabular}

Table 5.6: Annual mean temperature at the top of permafrost $\left(T_{p s} ;{ }^{\circ} \mathrm{C}\right)$ and mean snow depth (m) at sites 2 to 4 . Snow depth was measured at the temperature sensors. No temperature sensor was installed at site 1 due to rapid shoreline recession, but surface conditions were similar to site 2 . 
with a sandy layer near $1.5 \mathrm{~m}$ below the lake bottom and the mean sand, silt and clay volumetric fractions of the mineral sediment were respectively 20, 67, and $13 \%$. The average gravimetric organic content of the dry soil was estimated at $6 \%$.

\subsubsection{Lake ice and snow cover}

Lake-ice thickness at locations where ice did not reach the sediment varied between 1.04 and $1.55 \mathrm{~m}$ in late winter, with a mean of $1.30 \mathrm{~m}(\mathrm{n}=7)$ in 2009 and $1.45 \mathrm{~m}$ $(n=3)$ in 2010. At temperature monitoring sites where water depth was less than the mean maximum ice thickness, ice contact with the sediment generally occurred in October or November (Table 5.7).

The thickest on-ice snow drifts occurred at sites 1 and 4 (Fig. 5.3). These sites had high shore banks facing NE and SW, respectively, which correspond to the dominant wind directions in the area (Yukon Ecoregions Working Group, 2004) and, in the case of site 4, tall shrubs near the edge of the lake. These conditions resulted in snow drifts over $2 \mathrm{~m}$ thick that extended $45 \mathrm{~m}$ from shore at site 1 and $30 \mathrm{~m}$ from shore at site 4 . In contrast at site 2 , where the shore bank was $1 \mathrm{~m}$ high and the bank top vegetation was low shrub tundra, the snow drift was $0.73 \mathrm{~m}$ thick and extended less than $10 \mathrm{~m}$ onto the lake from the bank. Site 3 had a high bank with a well developed cover of tall shrubs but a less favourable orientation, and the $1.2-\mathrm{m}$ thick snow drift ended less than $10 \mathrm{~m}$ from the shore (Fig. 5.3).

\subsubsection{Bathymetry}

The two lakes were relatively flat bottomed and shallow, like the majority of lakes in OCF. The reported mean lake depth of $1.5 \mathrm{~m}$ (Gray and Alt, 2001) is slightly less than the maximum ice thickness measured in this study and suggests that a significant portion of the lakes may freeze to the bottom. Both lakes included shoreline sections where near-shore water was shallow, such as at site 4 , and areas where near-shore water was relatively deep, such as sites 1 and 2 . 


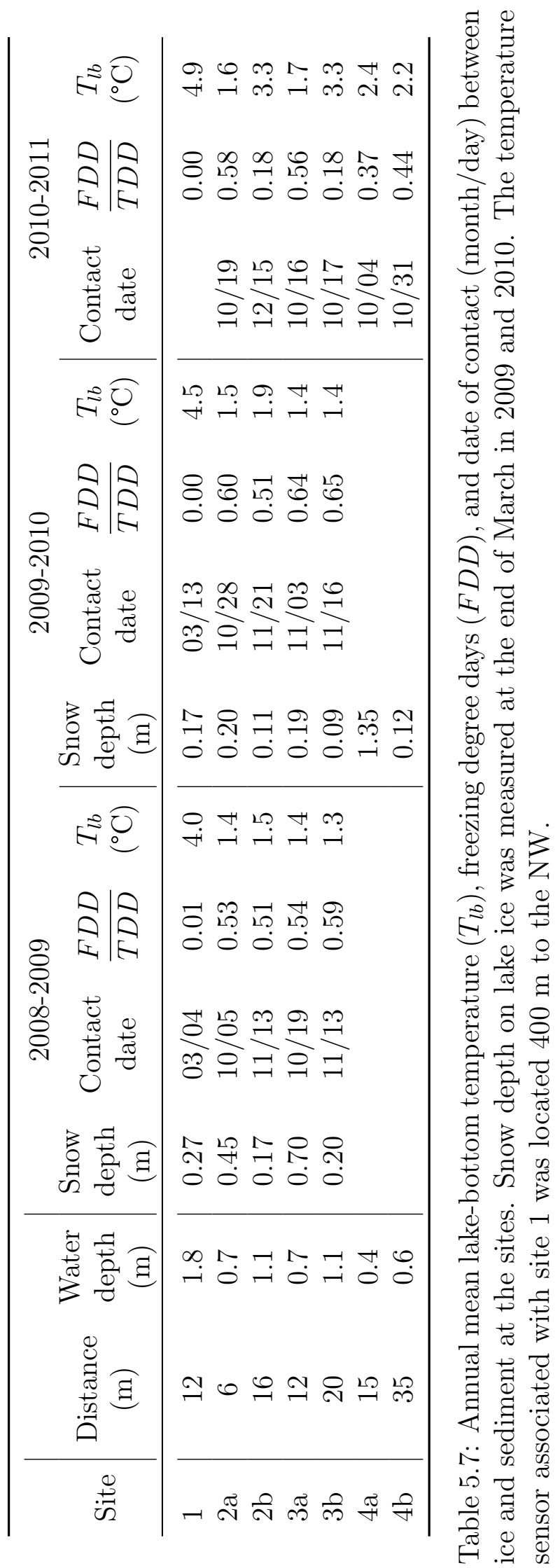




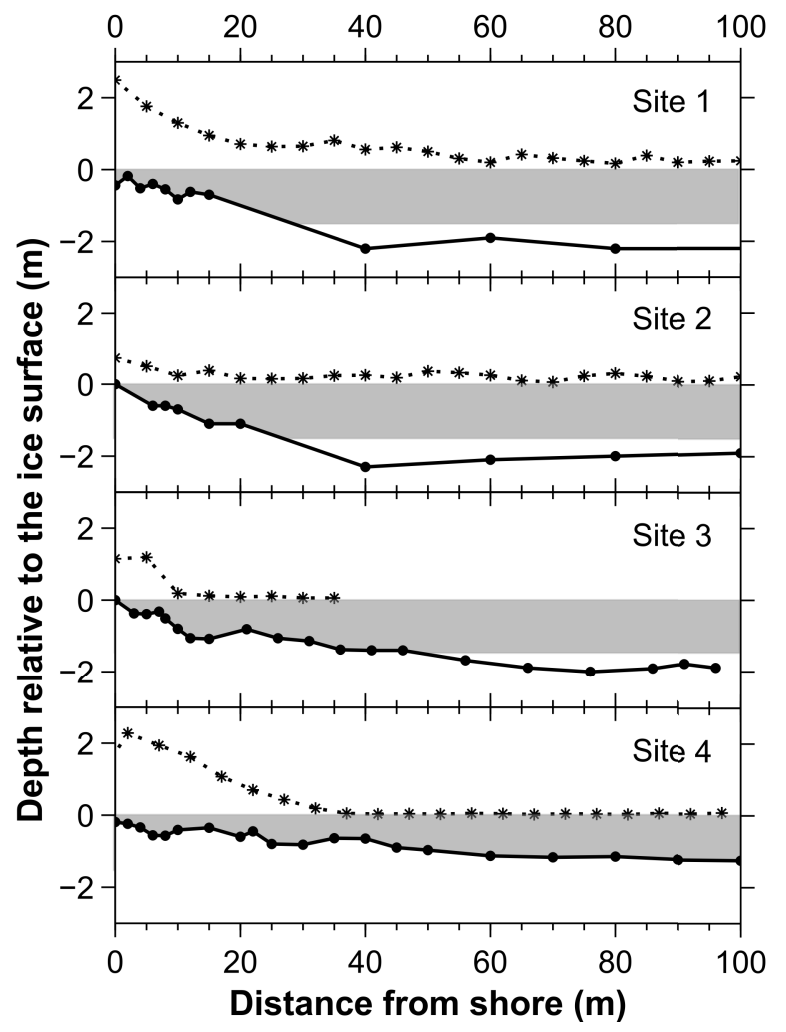

Figure 5.3: Near-shore bathymetry and snow depth at the four transects. The dotted line represents the snow thickness on the ice surface, with asterisks marking measurement points, and the grey area represents the maximum ice thickness, both based on measurements in March 2010. The solid line is the lake bottom, with black circles marking measurement points. 
Lake depth along the surveyed transects rarely exceeded $2.5 \mathrm{~m}$. A maximum depth of $3.1 \mathrm{~m}$ was measured $200 \mathrm{~m}$ from shore near site 1, while on the smaller lake the maximum water depth measured was $2.3 \mathrm{~m}, 40 \mathrm{~m}$ from site 2 (Fig. 5.3). The lake-bottom sloped gently away from the shoreline until a lake depth of approximately $2 \mathrm{~m}$ was reached. At sites 1 and 2, this slope extended approximately $40 \mathrm{~m}$ from the shore (Fig. 5.3). At site 4, the mean lake depth was reached more than $200 \mathrm{~m}$ from the shore, and lake depth was less than $1.5 \mathrm{~m}$ up to $130 \mathrm{~m}$ from the bank.

\subsubsection{Lake-bottom temperatures}

Annual mean lake-bottom temperature $\left(T_{l b}\right)$ values were $>0^{\circ} \mathrm{C}$ at all measurement sites. $T_{l b}$ values were between 4 and $5^{\circ} \mathrm{C}$ at a site where water depth was close to the maximum ice thickness and contact between the ice cover and bottom sediment

occurred in March (Fig. 5.4a, Table 5.7). $T_{l b}$ values varied between 1 and $2^{\circ} \mathrm{C}$ at the other sites, beneath shallow water, in most years. Higher $T_{l b}$ values were recorded in 2010-11, a year with reduced FDD in early winter and increased snowfall (Table 5.5 .

Where a near-shore snow drift developed, FDD near the lake edge were lower than or equal to $F D D$ further from the bank beneath deeper water. At site 4 in 2010-11, FDD were 103 less beneath the near-shore snow drift than below a thin snow cover, even though the ice reached the lake bottom earlier near shore (Fig. $5.4 \mathrm{~b})$. At site $3, F D D$ were 50 less beneath the near shore snow drift than further away from shore beneath a thin snow cover in 2008-09, and 26 less in 2009-10, despite a $0.4 \mathrm{~m}$ difference in water depth and earlier ice contact with the lake bottom near shore. The opposite relation was observed at this site in 2010-11, with 527 more $F D D$ near shore, possibly due to high overall snow depth reducing heat loss. 


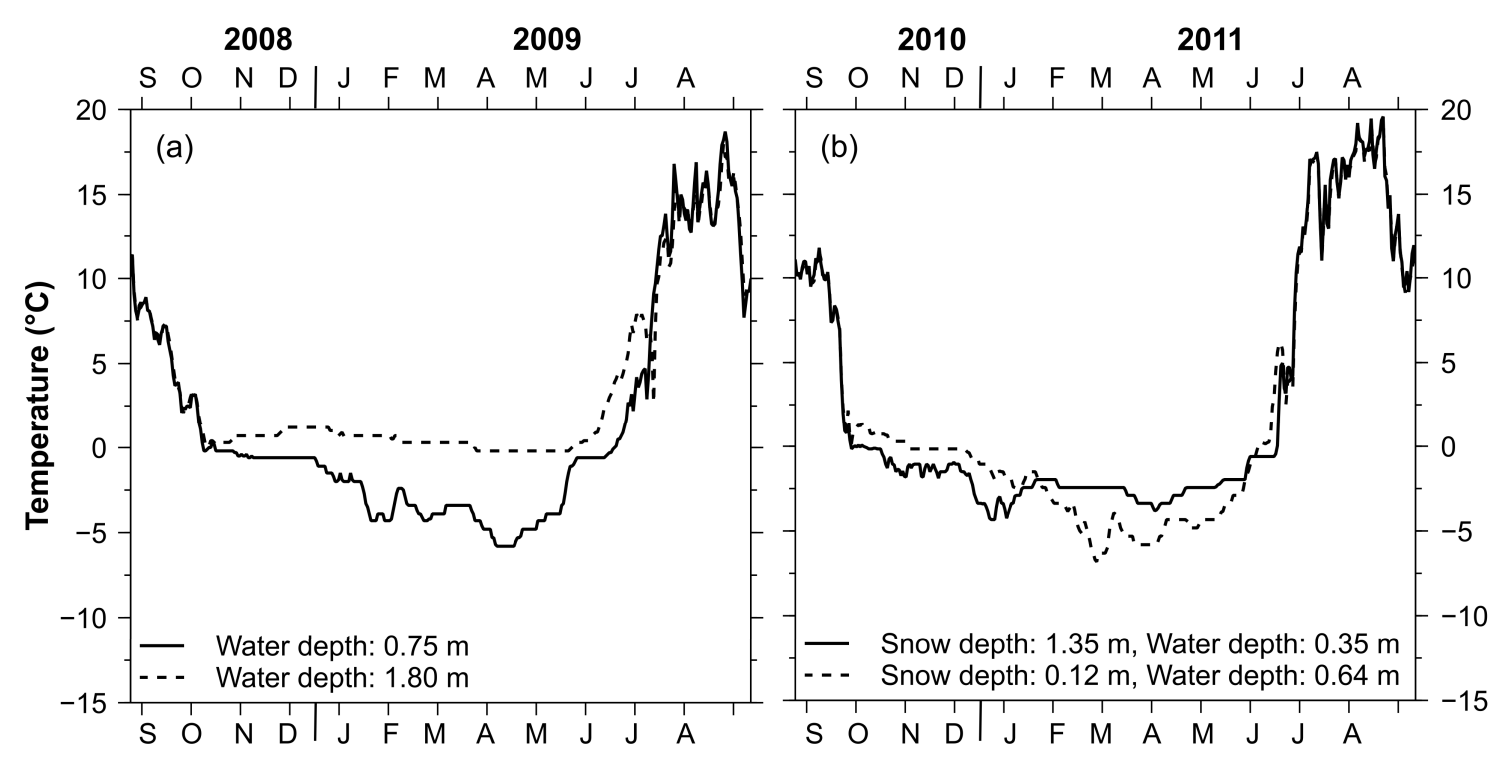

Figure 5.4: Effects of water and snow depths on lake-bottom temperatures. (a) Thermal regimes NE and SW of site 1, where ice reached the lake bottom at $75 \mathrm{~cm}$ depth and where water depth $(180 \mathrm{~cm})$ was greater than lake-ice thickness. The annual mean lake-bottom temperatures at these sites were $1.4^{\circ} \mathrm{C}$ and $4.0^{\circ} \mathrm{C}$ respectively. (b) Thermal regimes 12 and $20 \mathrm{~m}$ from shore at site 4 , where frost penetrated lake-bottom sediments but snow depth, controlled by the drift at the lake shore, modified the effects of water depth. The annual mean lake-bottom temperatures beneath and outside the snow drift were $2.4^{\circ} \mathrm{C}$ and $2.2^{\circ} \mathrm{C}$ respectively. 


\subsubsection{Frost penetration in the lake bottom}

A superficial layer of frozen sediment was encountered at all sites where ice was in contact with the lake bottom. This seasonally frozen sediment extended 15, 20, 43, and $150 \mathrm{~m}$ from shore at sites 1,2, 3 and 4 respectively, and had a maximum thickness of $2.40 \mathrm{~m}, 4 \mathrm{~m}$ from shore at site 4 . Full active layer freeze-back was only observed for a short distance from shore at sites 1, 2, and 3. It was observed furthest from shore at site 2, where the snow drift was thinnest and frost penetration deepest (Table 5.8). These data indicate that permafrost may be sustained if the on-ice snow depth declines, as observed by Stevens et al. (2010) in the outer Mackenzie Delta.

\subsubsection{Shoreline recession}

Long-term erosion rates estimated from aerial photographs ranged from 0.13 to 2.00 $\mathrm{m} \mathrm{a}^{-1}$ between 1951 and 1996, whereas short-term erosion rates measured in the field ranged from 0 to $3.9 \mathrm{~m} \mathrm{a}^{-1}$ (Table 5.9). The two shorelines with a NE aspect, sites 1 and 2, showed the highest erosion rates, had more exposed ground, occasionally developed overhanging peat curtains and erosional niches, and had deeper water near shore (Table 5.1). At site 4, with an extended zone of shallow water near shore, there was little shoreline recession (Table 5.9.

\subsubsection{Talik geometry}

The talik began near the edge of the lake at all four sites (Table 5.8). The basal slopes of the taliks were lowest at sites 1 and 2 where shore recession was most rapid (Fig. 5.5). Talik slopes followed a relatively uniform linear or concave shape at sites 1, 2 and 3. A break in slope near shore, where lake water froze to the bottom early in winter, formed a small near-shore shelf in the talik at sites 1, 2, and 3 (Fig. 5.5). The feature was difficult to distinguish at site 2. An extended shelf was observed in the talik boundary at site 4 , where water was shallow and frost penetration in the 


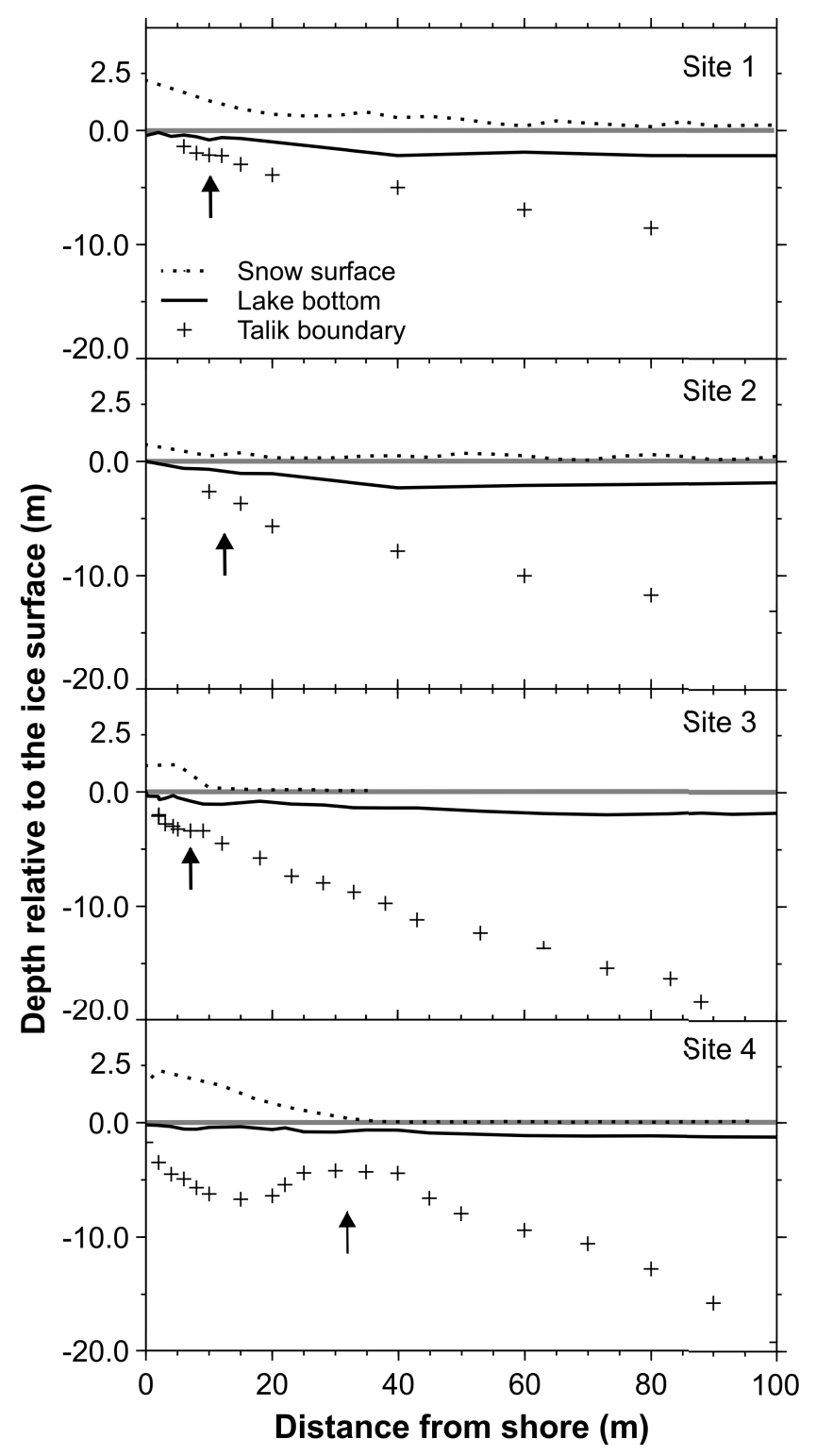

Figure 5.5: Near-shore talik depth relative to the ice surface (grey line) measured by jet drilling along each transect. Snow depth was measured in March 2010 and talik depths were measured in May and early June of 2009 and 2010. The near shore irregularity in the talik basal slope is indicated with an arrow in each graph. Note the difference in y-axis scale above and below the ice surface, resulting in a vertical exageration factor of 2 for snow thickness relative to lake and talik depths. 


\begin{tabular}{cccccc}
\hline Site & $\begin{array}{c}\text { Distance to } \\
\text { Talik } \\
(\mathrm{m})\end{array}$ & $\begin{array}{c}\text { Water } \\
\text { depth } \\
(\mathrm{m})\end{array}$ & $\begin{array}{c}\text { Max. snow } \\
\text { depth } \\
(\mathrm{m})\end{array}$ & $\begin{array}{c}\text { Frost penetration } \\
\text { depth } \\
(\mathrm{m})\end{array}$ & $\begin{array}{c}\text { Time before } \\
\text { talik initiation } \\
(\mathrm{yr})\end{array}$ \\
\hline 1 & $6( \pm 1)$ & 0.5 & $>2.2$ & $0.5( \pm 0.1)$ & $1.3( \pm 0.2)$ \\
2 & $10( \pm 1)$ & 0.6 & 0.7 & $1.1( \pm 0.1)$ & $5.0( \pm 0.2)$ \\
3 & $2( \pm 1)$ & 0.4 & 1.2 & $0.3( \pm 0.1)$ & $5.7( \pm 0.4)$ \\
4 & & 0.2 & 2.3 & $0.4( \pm 0.1)$ & \\
\hline
\end{tabular}

Table 5.8: Distance from the shoreline to the edge of the talik and conditions associated with talik initiation. Frost penetration below the lake bottom was measured near shore, where the talik begins. Time before talik initiation was calculated based on recession rates measured between 2009 and 2011 (Table 5.9). 


\begin{tabular}{lcc}
\hline Site & 1951-1996 $\left(\mathrm{m} \mathrm{yr}^{-1}\right)$ & $\begin{array}{c}\text { Spring 2009 to } \\
\text { autumn 2011 }\left(\mathrm{m} \mathrm{yr}^{-1}\right)\end{array}$ \\
\hline 1 & $2.00( \pm 0.07)$ & $3.9( \pm 0.1)$ \\
2 & $0.92( \pm 0.04)$ & $1.8( \pm 0.4)$ \\
3 & $0.33( \pm 0.04)$ & $0.7( \pm 0.2)$ \\
4 & $0.13( \pm 0.06)$ & $0.0( \pm 0.3)$ \\
\hline
\end{tabular}

Table 5.9: Rates of shoreline erosion at each study site. Erosion rates for 1951-1996 were obtained from aerial photographs and rates for 2009-2011 were based on field measurements. Erosion at site 4 was only monitored over the 2010 and 2011 open water seasons. 
lake bottom extended $150 \mathrm{~m}$ from the shore. A 2.4-m deep depression occurred in this shelf under the area of the near-shore snow drift (Fig. 5.5).

\subsection{Modelling results}

\subsubsection{Talik geometry and the Stefan solution}

Near shore, where water froze to the bottom in early winter, the Stefan solution with $T_{l b}=4.5^{\circ} \mathrm{C}$ gave poor agreement with measured talik depths. Agreement improved as distance from shore increased at sites 1 to 3 (Fig. ??a). Field measurements entered the zone of predicted values near 15, 20, and $45 \mathrm{~m}$ from shore at sites 1, 2, and 3, respectively (Fig. ??a), which correspond to the maximum distance from shore where frost penetration in the lake bottom was observed. Using a combination of two $T_{l b}$ values, as shown in Figure ??b, resulted in better agreement between measured and predicted talik depths at all sites, particularly near the shore.

The Stefan solution did not account for talik configuration at site 4, where frost penetrated the lake bottom along the entire transect, despite improved agreement over the first $20 \mathrm{~m}$ when using two $T_{l b}$ values (Fig. ??b).

\subsubsection{Talik initiation and interannual variations}

The effects on talik initiation of interannual variation in lake-bottom thermal regime were examined using numerical simulations over a period of 50 years, based on mean daily temperatures recorded $16 \mathrm{~m}$ from shore at site 2 in 2009-11 (Table 5.7).

The simulations did not initiate a talik within 50 years of submergence if lake-bottom conditions were defined only with temperatures recorded in 2009-10 ( $T_{l b}$ $=1.9^{\circ} \mathrm{C}$ ). Talik initiation occurred during the second year after submergence when the warmer lake-bottom conditions recorded in 2010-11 were used as boundary conditions (Fig. 5.7). When warmer lake-bottom conditions were inserted every second or third year, a talik appeared three or four years after submergence, but 


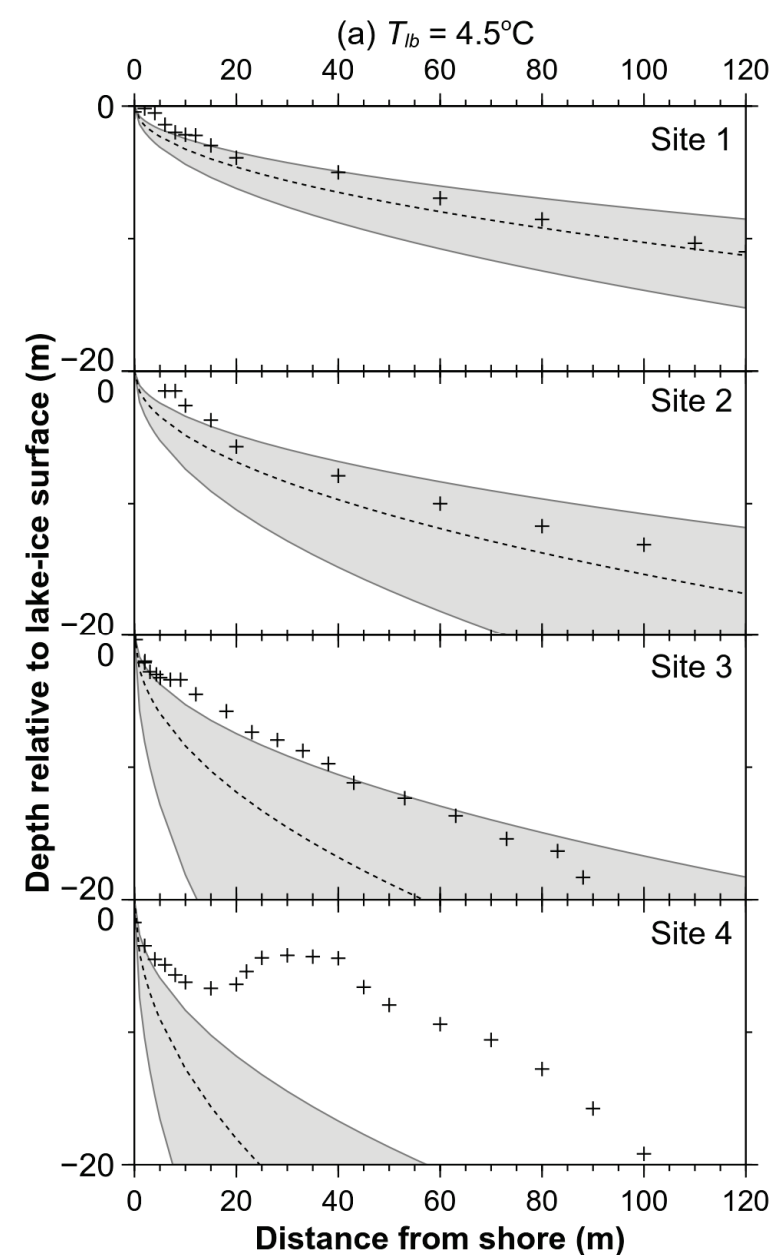

(b) $T_{\text {Ib }}=2.0^{\circ} \mathrm{C}$, then $4.5^{\circ} \mathrm{C}$

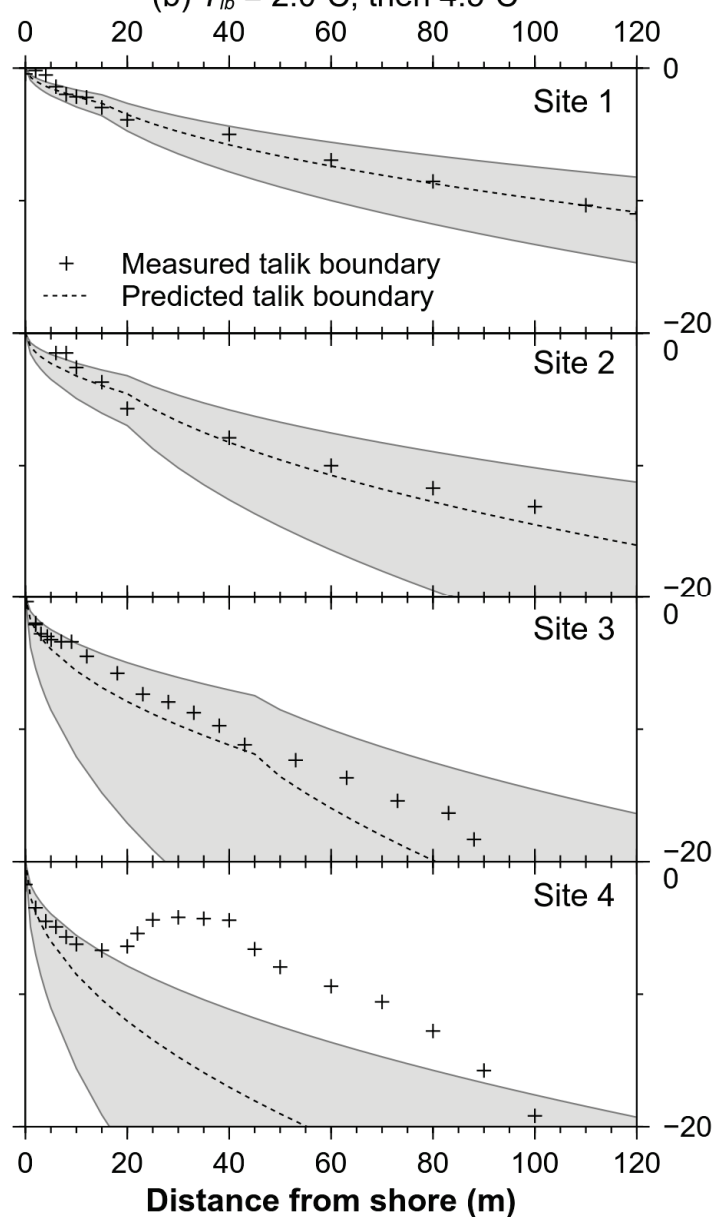

Figure 5.6: The Stefan solution compared to measured talik depths at the four sites. Calculations for the Stefan solution are based on a lake-bottom temperature at submergence of (a) $4.5^{\circ} \mathrm{C}$, and (b) $2.0^{\circ} \mathrm{C}$ for the initial period where the lake ice reached bottom, followed by $4.5^{\circ} \mathrm{C}$ when lake depth was greater than maximum ice thickness. The period with $T_{l b}=2.0^{\circ} \mathrm{C}$ is based on the rates of shoreline recession at each site: 8, 22, and 150 years at sites 1,2 , and 3 respectively. At site 4 , where ice reached bottom along the entire transect, $T_{l b}=2.0^{\circ} \mathrm{C}$ was used for the entire simulation. The uncertainty in predicted talik depth due to variations in rates of shoreline recession and ground thermal properties is represented by grey shading. See Subsection 5.4 .4 for an explanation of uncertainty calculations. 
fully refroze at least once before persisting and expanding steadily. Subsequently, a few centimetres of up-freezing occurred in the colder years (Fig. 5.7).

\subsubsection{Permafrost degradation rates and amplitude of the annual lake-bottom thermal regime}

The sensitivity of talik development rates beneath shallow water to variation in $F D D / T D D$ was examined using numerical simulations over 100 years with thermal regimes that had $T_{l b}=2.00^{\circ} \mathrm{C}$ and $F D D / T D D$ varying from 0.01 to 0.45 .

Simulations with mean daily temperatures were compared to simulations based on mean annual temperature.

Time to talik initiation decreased and rates of permafrost degradation increased as $F D D / T D D$ approached zero (Fig. 5.8). As the ratio increased, time to talik initiation and permafrost degradation rates both became increasingly sensitive to change in $F D D / T D D$. For ratios of 0.40 to 0.43 , time to talik initiation increased by 14 years, and talik depth 50 years after submergence was reduced by 24\%. No talik developed during the 100 year simulation when $F D D / T D D$ was

0.45. With a constant mean annual temperature $\left(T_{l b}=2.0^{\circ} \mathrm{C}\right)$, a numerical simulation gave similar results to thaw penetration rates with a $F D D / T D D$ below 0.2 (Fig. 5.8). The Stefan solution $(F D D=0)$, based on $T_{l b}=2.0^{\circ} \mathrm{C}$, overestimated all talik depths simulated numerically.

\subsubsection{Talik refreezing with $T_{l b}>0^{\circ} \mathrm{C}$}

The third numerical experiment assessed whether talik refreezing could occur under thermal conditions observed in OCF by applying mean daily temperatures recorded at sites 2 and 3 in 2009-10 and at site 4 in 2010-11 as boundary conditions for 100 years after a 6.9-m deep talik had been simulated.

Talik refreezing did not occur when the temperature regimes recorded at site 4 in 2010-11 were applied as upper boundary conditions (Fig. 5.9). The FDD/TDD 


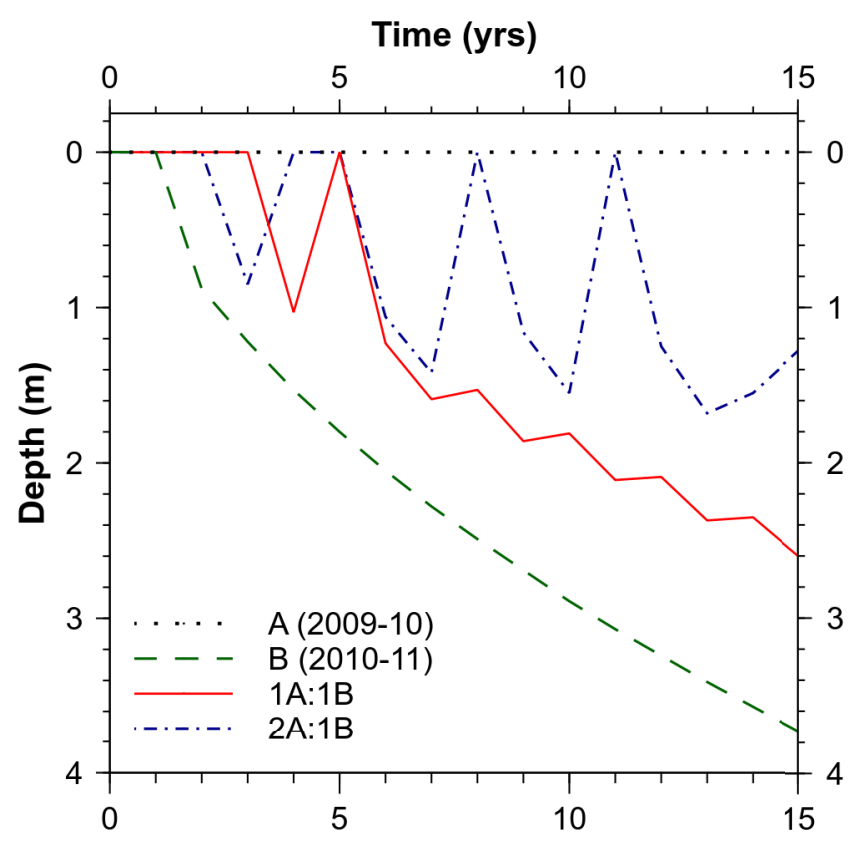

Figure 5.7: The first 15 years of a 50-year simulation of talik initiation and development after submergence with daily mean lake-bottom temperatures measured at site 2 in 2009-10 (A), and 2010-11 (B). Temperature data from 2009-10 and 2010-11 were alternated (1A:1B), or data from 2010-11 was inserted one year out of three (2A:1B). 

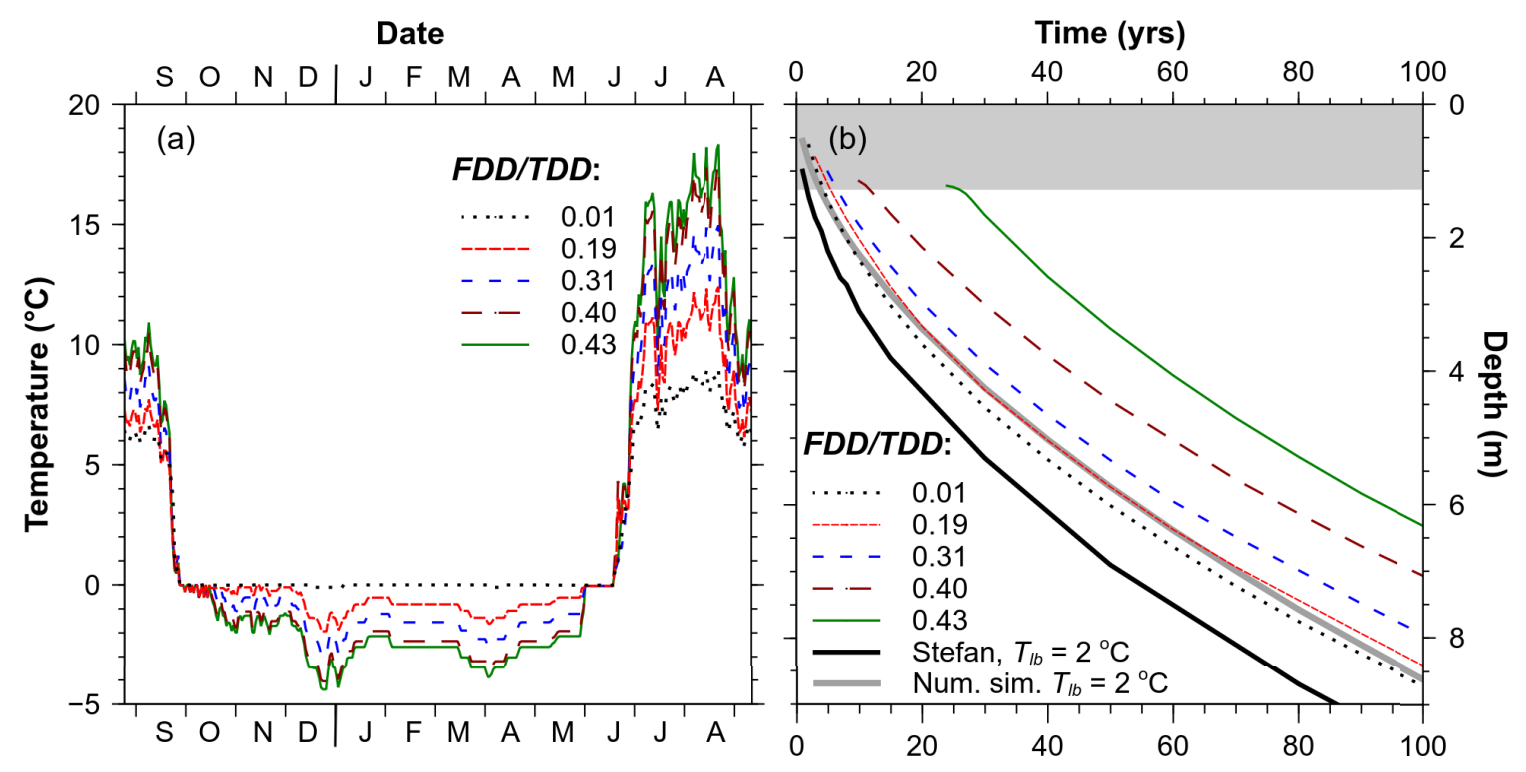

Figure 5.8: (a) Six thermal regimes of varying amplitude with $T_{l b}=2.00^{\circ} \mathrm{C}$ and 252 days of ice contact with the lake bottom and (b) the associated talik development rates. Talik depth was defined as the maximum depth of ground that remained below $0^{\circ} \mathrm{C}$ year round. Thermal regimes with $F D D / T D D \geq 0.45$ did not lead to the development of a talik within 100 years and are not shown. The maximum active-layer depth simulated with the thermal regimes shown was $1.28 \mathrm{~m}$, with a $F D D / T D D$ ratio of 0.43 , and is indicated with grey shading in the upper portion of the graph. 


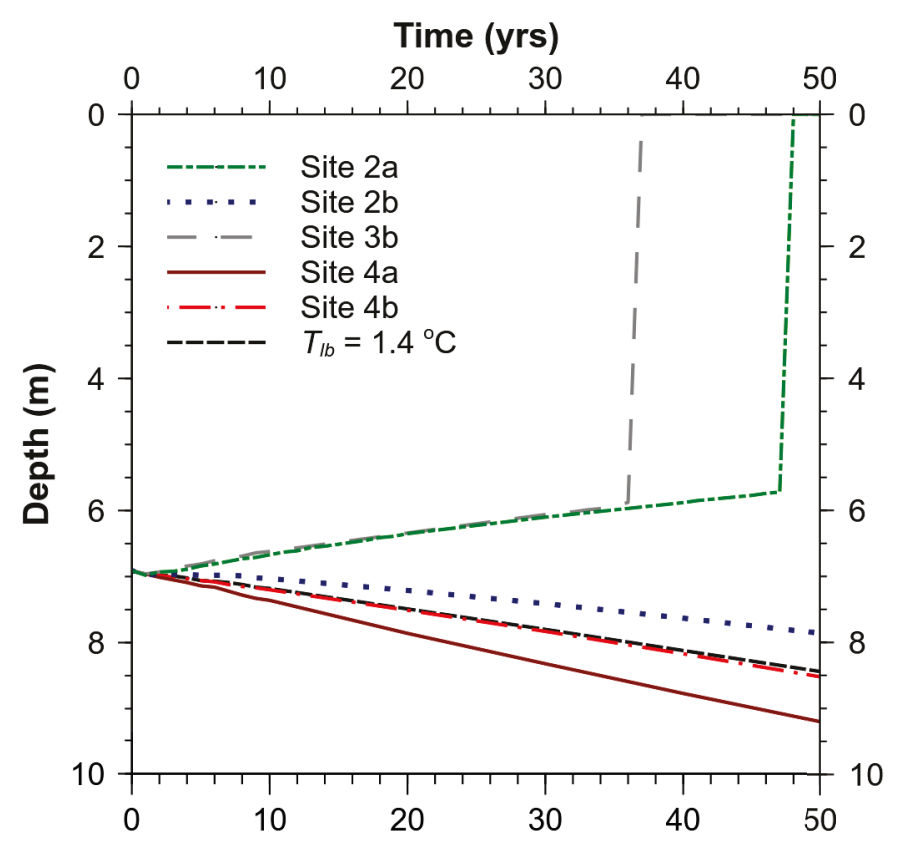

Figure 5.9: Talik development and refreezing with six different lake-bottom thermal regimes applied after a talik has developed to a depth of $6.9 \mathrm{~m}$. Sites $2 \mathrm{a}$ and $4 \mathrm{a}$ were close to the shoreline and sites $2 \mathrm{~b}, 3 \mathrm{~b}$, and $4 \mathrm{~b}$ were located past the near-shore snow drift (Table 5.7). A constant lake-bottom temperature of $1.4^{\circ} \mathrm{C}$ was applied at the lake bottom for $T_{l b}=1.4^{\circ} \mathrm{C}$. Data were collected in 2009-10 at sites 2 and 3, and in 2010-11 at site $4 . T_{l b}$ and $F D D / T D D$ for each dataset were as follows: $2 \mathrm{a}, 1.5^{\circ} \mathrm{C}$, $0.60 ; 2 \mathrm{~b}, 1.9^{\circ} \mathrm{C}, 0.51 ; 3 \mathrm{~b}, 1.4^{\circ} \mathrm{C}, 0.65 ; 4 \mathrm{a}, 2.4^{\circ} \mathrm{C}, 0.37 ; 4 \mathrm{~b}, 2.2^{\circ} \mathrm{C}, 0.44$. 
ratios for these temperature regimes were 0.37 and 0.44 (Table 5.7). Complete refreezing of the $6.9 \mathrm{~m}$ talik occurred within 50 years when temperature regimes recorded at sites 2a or 3b in 2009-10 were applied. These temperature regimes had $T_{l b}$ values of 1.5 and $1.4^{\circ} \mathrm{C}$ and $F D D / T D D$ of 0.60 and 0.65 , respectively (Table 5.7). However, the talik continued to deepen when the temperature regime recorded at site $2 \mathrm{~b}$ was applied, which had a $T_{l b}$ of $1.9^{\circ} \mathrm{C}$ and a $F D D / T D D$ of 0.51 . When the mean daily lake-bottom temperatures recorded at site $3 \mathrm{~b}$ were replaced with the annual mean temperature, $1.4^{\circ} \mathrm{C}$, the talik deepened.

\subsection{Discussion}

The following discussion concentrates on the implications of our results for talik development near thermokarst lake shores. In particular, we discuss: (1) characteristics of the lake-bottom thermal regime associated with $T_{l b}>0^{\circ} \mathrm{C}$ where water froze to the bottom; (2) controls on talik initiation beneath shallow water near receding shorelines; and (3) talik geometry near thermokarst lake shores and limits to the effectiveness of the Stefan solution.

Our aim is to assess whether approaches developed to predict near shore talik development beneath tundra lakes of the western Arctic coast Mackay, 1992) Burn, 2002 and thermokarst lakes in the boreal forest of central Yukon Burn and Smith, 1990) are consistent with field observations in tundra lakes of the Old Crow Flats, and to investigate inconsistencies with a simple numerical model. Near the western Arctic coast, permafrost is sustained beneath water depths less than $2 / 3$ of the maximum ice thickness, where the mean lake-bottom temperature $\left(T_{l b}\right)$ is below $0^{\circ} \mathrm{C}$ Mackay, 1992; Burn, 2002; Stevens et al., 2010). In thermokarst lakes of central Yukon, talik development near receding shores has been effectively predicted with the Stefan solution based on $T_{l b}$ and shore recession rates. 


\subsubsection{Lake-bottom temperatures beneath shallow water}

$T_{l b}$ is used as a key variable to predict talik extent near thermokarst lakeshores, and in $\mathrm{OCF}$ we have measured $T_{l b}$ under a range of water depths at various distances from shore. $T_{l b}$ values determined in OCF were higher than reported values from tundra lakes near the western Arctic coast, which range from -1 to $-6^{\circ} \mathrm{C}$ in shallow areas and from 2 to $4^{\circ} \mathrm{C}$ where ice does not reach lake-bottom sediments Brewer, 1958; Arp et al. 2011; Burn, 2002, 2005). At the sites examined in this chapter, all $T_{l b}$ values were above $0^{\circ} \mathrm{C}$ (Table 5.7), which is similar to conditions in thermokarst lakes of central Yukon Burn, 2003). In central Yukon, however, ice did not reach the lake bottom and $T_{l b}$ values were higher beneath shallow water near shore than near the deeper lake centre. This is contrary to conditions observed in OCF, where frost penetrated the lake-bottom sediment near shore and $T_{l b}$ values were lower beneath shallow than deep water, similar to tundra lakes of the western Arctic.

During summer, near-shore lake-bottom temperatures in the tundra of OCF increased earlier and reached higher values than those recorded in tundra lakes of the Mackenzie Delta area (Burn, 2005), likely due to the shallow water of the OCF lakes. During winter, once the water column froze through, lake-bottom temperatures in OCF did not decrease as rapidly and as much as in the Mackenzie Delta area. Winter air temperatures at Old Crow are similar to or lower than those at Tuktoyaktuk, suggesting that the higher winter lake-bottom temperatures in OCF are due to the insulation provided by near-shore snow drifts that trap latent and sensible heat released by the talik. However $T_{l b}$ values beneath shallow water were above $0^{\circ} \mathrm{C}$ regardless of snow-cover thickness or water depth (Table 5.7), suggesting that the warm summer conditions in OCF, compared to cooler summer conditions along the Arctic coast, are the determining factor in raising $T_{l b}$ above $0^{\circ} \mathrm{C}$ in shallow areas. This result supports climate-change sensitivity analyses conducted by Burn (2002) for lakes with littoral shelves on Richards Island, indicating that an 
increase in thaw-season lake-bottom temperatures and on-ice snow thickness may cause near-shore permafrost to degrade.

\subsubsection{Talik initiation beneath shallow water}

In the Mackenzie Delta region, Mackay 1992) observed that taliks occurred beneath water depths greater than approximately two-thirds of the maximum lake-ice thickness. Similarly, at a tundra lake on Richards Island, Burn (2002) observed that the edge of permafrost occurred beneath a water depth of $1 \mathrm{~m}$, which was $60 \%$ of the mean maximum lake-ice thickness in the area $(1.67 \mathrm{~m})$. In this study, however, talik initiation near shore occurred under water depths less than $40 \%$ of the maximum measured ice thickness on all the transects and was sometimes found beneath water as shallow as $20 \mathrm{~cm}$, or $13 \%$ of the maximum ice thickness. Over the course of the study period, variations in water levels up to $\pm 15 \mathrm{~cm}$ were observed at the study sites. There were no indications in the bank morphology or on the aerial photographs that water levels in these lakes were higher in the past. However Labrecque et al. (2009) report a general decrease in lake water levels in OCF associated with warmer and drier climate between 1977 and 2001. Turner et al. (2010) indicate that water levels have recently increased in the area due to above normal precipitation, particularly during 2006 and 2007. Total precipitation was also above normal in 2011 (Table 5.5). The recent increase in water levels may explain the difference between the long-term shore recession rate estimated from aerial photographs and the short-term erosion rates measured in the field (Table 5.9) (Brouchkov et al., 2004), but cannot explain the presence of taliks beneath shallow water near shores.

The high $T_{l b}$ values and near-shore talik initiation observed beneath shallow water in $\mathrm{OCF}$ are inconsistent with talik configuration on the western Arctic coast, indicating that the rules of thumb developed for thermokarst lakes in the Mackenzie Delta area do not apply in OCF. In the latter area, the presence of taliks within 10 
$\mathrm{m}$ of receding shorelines suggests not only that permafrost is not sustainable near-shore, but also that conditions are favorable for talik initiation within six years of submergence (Table 5.8).

Talik development under shallow water near shores in OCF appears consistent with the warm near-shore lake-bottom conditions, but the relation between $T_{l b}$ and annual mean temperature at the bottom of the seasonally frozen layer is moderated by the thermal offset Kudryavtsev, 1981; Burn, 1988; Romanovsky and Osterkamp, 1995). The thermal offset results from the ratio of $\lambda \mathrm{t}$ to $\lambda \mathrm{f}$ in the layer of ground that freezes and thaws seasonally, and controls whether permafrost can be sustained where thermal conditions at the ground surface are close to, but above $0^{\circ} \mathrm{C}$. The limit of permafrost sustainability, where mean temperature at the bottom of the seasonally frozen layer is $0^{\circ} \mathrm{C}$, occurs where $F D D \lambda_{f}$ is equal to $T D D \lambda_{t}$, or $F D D / T D D$ is equal to $\lambda_{t} / \lambda_{f}$ (Romanovsky and Osterkamp, 1995). This principle was used by Stevens et al. (2010) to determine where permafrost may be sustained under the bottom-fast ice of the outer Mackenzie Delta. In our study, $\lambda_{t} / \lambda_{f}$ of 0.51 was estimated from the two sets of lake-bottom core samples extracted at site 1 (Table 5.4.

In the $\mathrm{OCF}$, field measurements of $F D D / T D D$ varied from year to year and were often close to $\lambda_{t} / \lambda_{f}$ (Table 5.7). However, the unfrozen water content of the frozen lake-bottom sediment reduces the effective $\lambda_{f}$ which, in reality, is not a single value but a function of sediment temperature below $0^{\circ} \mathrm{C}$ Romanovsky and Osterkamp, 2000; Riseborough, 2002). This results in the limit of permafrost sustainability shifting towards higher $F D D / T D D$. Permafrost degradation continued steadily for 50 years when the thermal regime recorded $16 \mathrm{~m}$ from shore at site 2 in 2009-10, with $F D D / T D D=0.51$, was applied in a simulation above a talik $6.9 \mathrm{~m}$ deep (Fig. 5.9). However, a simulation of talik initiation using the same thermal regime indicated that talik initiation would not occur within 50 years of submergence (Fig. 5.7), unless data from 2010-11, when lake-bottom conditions 
were warmer than in 2009-10, were inserted at regular intervals in the temperature series (Fig. 5.7).

This difference in heat input requirement between talik initiation and development is consistent with reported effects of unfrozen water content on permafrost degradation after a step change in surface conditions Romanovsky and Osterkamp, 2000). Unfrozen water introduces a latent heat sink distributed over a range of sub-zero temperatures, increasing the apparent heat capacity of the permafrost as temperatures approach $0^{\circ} \mathrm{C}$ Riseborough, 1990). The unfrozen water content thus increases the thermal inertia of permafrost and delays talik initiation, as heat is used to thaw ice in the warming subjacent permafrost. Where a talik is already established, such as specified in Figure 5.8, the ground beneath the thaw front has warmed during talik development and requires less heat to reach $0^{\circ} \mathrm{C}$. Similarly, the occurrence of years with higher than average lake-bottom temperatures accelerates the warming of permafrost and can facilitate talik initiation after submergence (Fig. 5.7).

The presence of taliks near shore beneath very shallow water in OCF is partly explained by the high $T D D$ at the lake bottom during the warm summers, which balances the $F D D$ and difference in thermal conductivity. However, such taliks would not initiate close to receding shores without the intermittent occurrence of lake-bottom conditions that accelerate permafrost warming below the active layer. Such conditions favorable to talik development may result from the occurrence of above normal winter or summer air temperatures, or from increased on-ice snow depth during ice contact with the lake bottom. Conditions favoring talik initiation may also be associated with increased water levels resulting in a decrease in the duration of ice contact with the lake-bottom sediment (Stevens et al., 2010). 


\subsubsection{Talik geometry near receding shores in shallow lakes}

Talik geometry near receding shorelines is controlled by the rate of permafrost degradation and time since submergence. In central Yukon, Burn (2003) found that $T_{l b}$ values were generally uniform over the lake bottom, which supported the Stefan solution assumption that lake expansion acts as a step change in surface temperature (Burn and Smith, 1990). In the tundra of OCF, our field results indicate that $T_{l b}$ values varied spatially where water depth was less than the maximum lake-ice thickness (Table 5.7), but the Stefan solution was still consistent with measured talik depths at the first three sites (Fig. ??). At these sites, seasonal freezing and thawing of the lake bottom were limited in duration by shore recession rates and bathymetry. Agreement with field measurements was improved when a $T_{l b}$ typical of near-shore conditions was used to calculate the early phase of thaw penetration (Fig. ??). This indicates the effectiveness of approaches based on $T_{l b}$ that allow for thermal variability along the lake bottom where freezing and thawing are limited.

At site 4, where shore recession was slow and water froze to the bottom over an extended area, a step change in surface temperature poorly represented the spatial variability of lake-bottom conditions and there was little agreement between the simulated and measured talik depths (Fig. ??). Near-shore talik geometry at this site did not follow an exponential shape. Instead, there was a depression in the talik boundary beneath a snow drift and reduced talik depths further from the shore where the snow cover was thin. Such a talik configuration may result from the snow drift, for while measured $T_{l b}$ differed by only $0.2^{\circ} \mathrm{C}$ at the two monitored points along the lake bottom, $F D D / T D D$ varied from 0.37 to 0.44 (Table 5.7). Numerical modelling showed that changes in FDD/TDD, even without changes to the annual mean temperature, may cause pronounced differences in the rate of talik development, particularly for lake-bottom thermal regimes with $F D D / T D D$ over 0.3 (Fig. 5.8). 
Such a difference in rate of thaw penetration may explain a talik geometry as that of site 4 if the shoreline is static but not if the shore is receding constantly, unless refreezing of the talik occurs further from shore. Numerical simulation showed that whereas lake-bottom thermal conditions recorded beneath thin snow at site 4 in 2010-11 would not allow for talik refreezing, refreezing may occur when $F D D / T D D \geq 0.53$ (Fig. 5.9). Such high FDD/TDD values were recorded each year at sites 2 and 3, and indicate that refreezing may be an important component of talik development where ice reaches the lake bottom, despite $T_{l b}$ values above $0^{\circ} \mathrm{C}$. This result emphasizes the importance of the thermal offset and interannual variability to assessments of talik development under marginal thermal conditions.

\subsubsection{Temporal resolution}

The general practice when modelling talik development is to use a temporal resolution of one year for lake-bottom thermal conditions, assuming that variations in the lake-bottom thermal regime that affect talik development are captured by changes in $T_{l b}$ Ling and Zhang, 2004; West and Plug, 2008; Kokelj et al., 2009; Matell et al., 2013; Rowland et al., 2011). A finer temporal resolution is rarely used Zhou and Huang, 2004, so that long periods can be modelled efficiently. Areas of shallow water that freeze to the bottom are rarely taken into account Burn, 2002; Ling and Zhang, 2004) as they are generally assumed to have a $T_{l b} \leq 0^{\circ} \mathrm{C}$. Our results emphasize the importance of $F D D / T D D$ at the lake bottom to model talik initiation and rates of permafrost degradation where the water column freezes through, and the risk of improper simulation when relying on annual mean temperature under these conditions without consideration of the thermal offset.

\subsection{Conclusions}

Our main findings are that: 
1. Mean annual lake-bottom temperature beneath shallow water that froze to the lake bottom in early winter was above $0^{\circ} \mathrm{C}$, due to high summer temperatures and on-ice near shore snow drifts trapping latent heat during winter.

2. Taliks were found under water depths of as little as $20 \mathrm{~cm}$, considerably less than the maximum winter ice thickness.

3. Where ice reaches the lake-bottom sediment, talik development rates are moderated by the ratio of freezing degree days to thawing degree days and the thermal offset.

4. Variability in the ratio of freezing degree days to thawing degree days at the lake bottom, even without change in the annual mean lake-bottom temperature, affects rates of talik development and may cause talik refreezing.

5. Predictions of talik profiles based on mean annual lake-bottom temperatures were effective where the influence of lake-bottom freezing and thawing were limited in time by shore recession rates and bathymetry, but overestimated talik depths where exposure to freeze-thaw cycles was prolonged.

6. Annual mean temperature at the lake bottom close to shore was relatively unaffected by spatial variations in on-ice snow depth, but freezing degree-days at the lake bottom varied sufficiently to affect rates of permafrost degradation beneath the lake.

7. Where thermal conditions recorded in the field are marginal for talik development, interannual variations in lake-bottom thermal regime are likely key for talik initiation near receding shores.

Our results also emphasize that permafrost vulnerability in the near-shore zone of thermokarst lakes may be affected by regional variations in air temperature, snow fall and redistribution by wind, ground-ice distribution, and lake bathymetry. 
This variability must be considered when predicting talik initiation and permafrost degradation in thermokarst landscapes. 


\section{Chapter 6}

\section{Topography of drained lake basins}

\section{Modified from a manuscript to be submitted as:}

Roy-Léveillée P., Burn C. R. Internal topography of drained lake basins in the Old Crow Flats, Y.T. To be submitted for publication in Earth Surface Processes and Landforms.

\subsection{Introduction}

Arctic lowlands $(<300 \mathrm{~m}$ a.s.l.) in the permafrost zone of northwest Canada,

Alaska, and northern Siberia contain tens of thousands of thermokarst lakes Grosse et al., 2013). The lakes form by thawing of ice-rich permafrost, settlement of the ground, and ponding at the surface (Rampton, 1988; Mackay, 1992). The evolution of thermokarst lakes through initiation, drainage, permafrost recovery in the drained basins, and renewed thermokarst development constitutes the thermokarst lake cycle (Britton, 1967; Billings and Peterson, 1980, Jorgenson and Shur, 2007). This cycle greatly influences the exchange of carbon dioxide and methane between Arctic lowlands and the atmosphere (Walter et al., 2006; Sturtevant and Oechel, 2013 ; Walter-Anthony et al., 2014).

The expansion of thermokarst lakes is interrupted by drainage, commonly catastrophic (Mackay, 1988; Balcerak, 2011; van Huissteden et al., 2011). After drainage, permafrost aggradation can lead to uneven topography in drained basins Jorgenson and Shur, 2007; Bockheim and Hinkel, 2012), creating a range of moisture conditions associated with depressed areas containing ponds, gentle slopes, and raised surfaces (Jorgenson and Shur, 2007, Bockheim and Hinkel, 2012). Such 
variations in moisture conditions influence the magnitude and relative proportions of methane and carbon dioxide emitted from these surfaces van der Molen et al. 2007; Sturtevant and Oechel, 2013).

Drained thermokarst lake basins are commonly characterized by an internal topography where the basin centre is raised above the depressed margins Jorgenson and Shur, 2007; Regmi et al., 2012; Grosse et al., 2013). On the Arctic Coastal Plain of Alaska the low relative elevation of drained basin margins has been attributed to the poor frost-heave potential of gravelly sand which accumulates near shore and the influence of shallow littoral terraces on permafrost configuration beneath lakes (Jorgenson and Shur, 2007; Jorgenson et al., 2003). Drained basins with similar internal topography are also found in other Arctic lowlands where the surficial geology and lake bathymetry are markedly different from the Arctic Coastal Plain Grosse et al., 2013). In Old Crow Flats (OCF) of northern Yukon (Fig. 6.1), flat-bottomed thermokarst lakes have developed in fine-grained glaciolacustrine silts Gray and Alt, 2001). Depressed margins and raised centres have developed in several drained basins despite the uniform soil composition in this silty plain and the absence of littoral terraces in the lakes.

In this chapter we investigate the potential genesis of such basin topography by examining relations between elevation, peat thickness, excess-ice content, ice-wedge distribution, and sediment stratigraphy in three drained-lake basins in a tundra area of OCF. Our working hypothesis is that the development of depressed margins and raised centres is not dependent on gradients in frost-susceptibility or ice-wedge density along the lake bottom. Our specific objectives are to (1) examine surface conditions in three drained basins of a tundra area in OCF, (2) determine whether topography is controlled by near-surface excess-ice content, and (3) if existing models are insufficient, propose a modified landform development model for the internal topography of drained basins that is adapted to conditions similar to those found in OCF. 


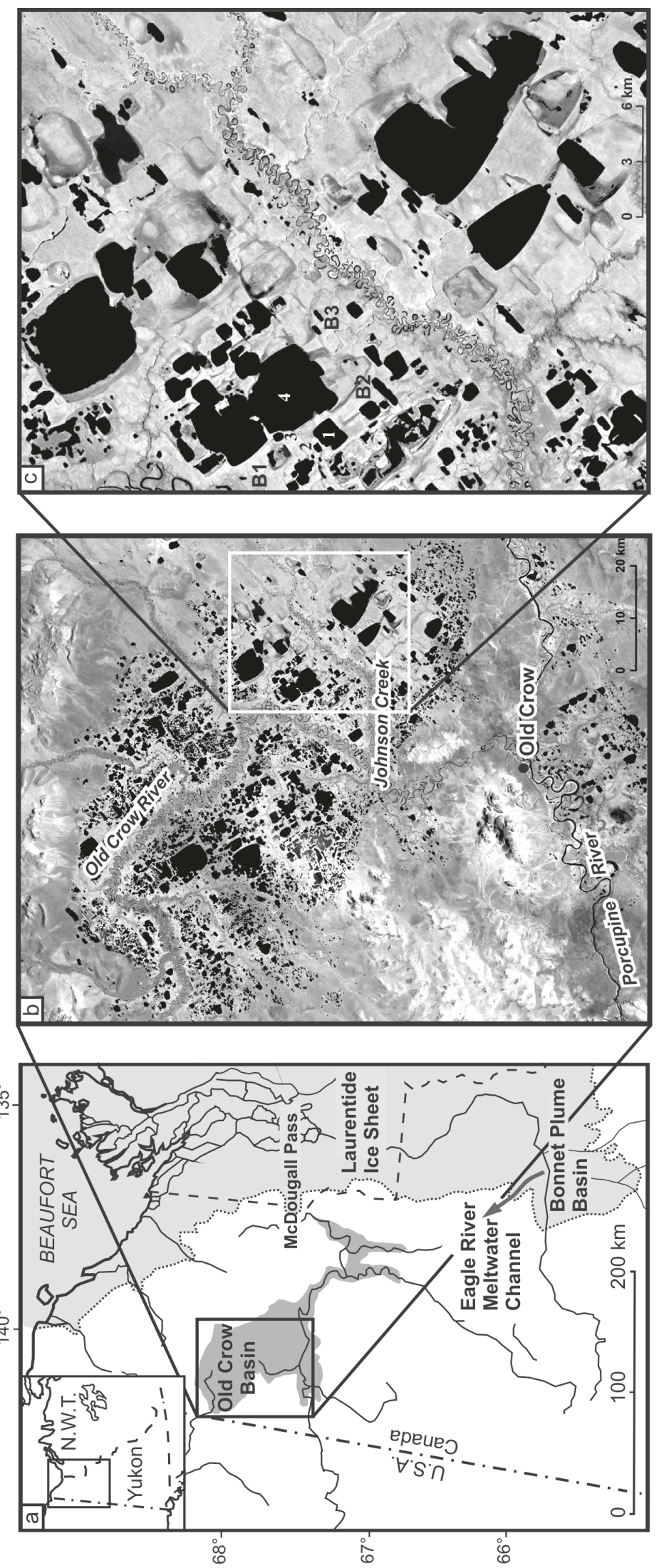

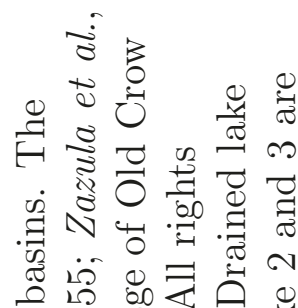

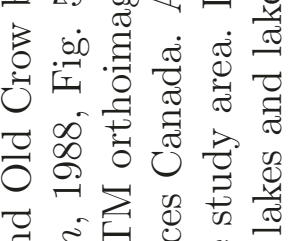

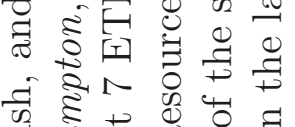

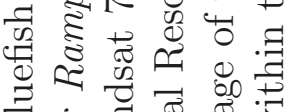

$\overline{0}$

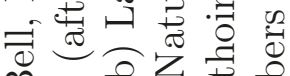

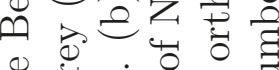

炙它穴艺口

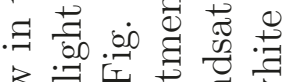

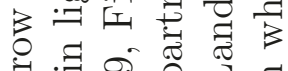

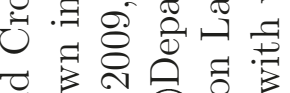

궁

幽

$\neg$ サ

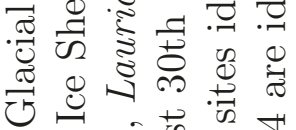

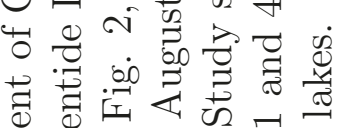

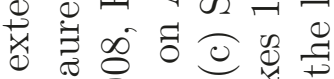

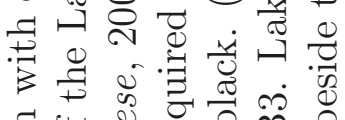

₹ี

水.

تี

营

乙.

( )

๘

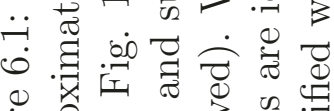

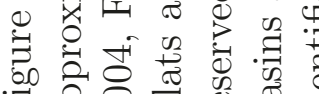

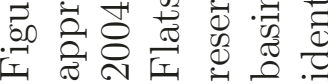




\subsection{Thermokarst lake sediments}

The thermokarst lake cycle culminates the expansion of a thermokarst lake in drainage followed by permafrost recovery in the drained-lake basin, allowing for subsequent lake re-initiation, expansion, and repetition of the cycle (Britton, 1967; Billings and Peterson, 1980; Jorgenson and Shur, 2007).

Thermokarst lakes initiate when a change in surface conditions causes the thawing of permafrost that contains excess ice. As a result, the ground subsides when it thaws and depressions develop that are preferential loci for ponds Burn, 1992). If thaw penetration in sediments beneath the pond exceeds the depth of seasonal frost penetration, a body of perennially unfrozen ground, or talik, develops Mackay, 1992). The lake bottom subsides as permafrost thaws and, at equilibrium, overall lake bathymetry reflects the volume of excess ice in the ground thawed during talik development (Mackay, 1992; West and Plug, 2008; Hinkel et al., 2012). On the Alaskan North Slope, lakes up to 25 m deep have been reported from areas of yedoma sediments where syngenetic ice wedges and segregated ice extend tens of metres below the surface (Carter, 1988, Hopkins and Kidd, 1988). In areas with ground ice only near the surface, such as in drained lake basins, thermokarst lakes tend to be shallow and flat-bottomed (Hopkins and Kidd, 1988; West and Plug, 2008; Morgenstern et al., 2011)

Thermokarst lakes also expand laterally because their shores are subject to thaw subsidence following conduction of heat from the lake into the sediment, slumping where denuded permafrost is exposed to the air, thermo-mechanical erosion where there is contact between water and permafrost, and block failures where banks have been undercut (Grosse et al., 2013). These processes may bring masses of organic and inorganic material into the lake for sorting and redistribution along the lake bottom (Hinkel et al., 2012; Grosse et al., 2013). Wave and current winnowing separates fine material such as silt and clay from coarse materials, such 
as detrital peat, fine sand, pebbly sand, and gravel. The fines may be carried in suspension towards the lake centre, while the coarse fraction, which travels by traction and saltation, is concentrated close to shore where water is shallow and wave action causes re-suspension of the lake-bottom sediment Britton, 1967; Hopkins and Kidd, 1988; Murton, 1996). As the shoreline of a thermokarst lake expands and the lake bottom subsides, the coarse fraction deposited beneath shallow water is eventually overlain with fine sediment deposited by suspension settling beneath deeper water Hopkins and Kidd, 1988; Murton, 1996). Commonly, thermokarst lakes in sandy and clastic deposits have littoral terraces made of sands and gravels whose front separates deeper water in the lake centre from shallow water $(<1 \mathrm{~m})$ beneath which permafrost is preserved (Murton, 2001; Burn, 2002). In fine sediments, such as glaciolacustrine silts and clays, littoral terraces are not common and subsidence of the lake bottom leads to a 'pan-shaped' or a 'bowl-shaped' bathymetry (Burn and Smith, 1990; West and Plug, 2008, Hinkel et al., 2012).

In continuous permafrost, growth of a thermokarst lake often terminates with catastrophic drainage via fluvial tapping, expansion of adjacent lakes, truncation due to rapid coastal retreat, or overflow during snow melt initiating drainage by ice-wedge erosion (Mackay, 1988, Burn, 1992). Permafrost aggrades in the exposed basin sediment and near-surface aggradational ice develops in the years following drainage, uplifting the basin floor Mackay, 1972; Mackay and Burn, 2002; Bockheim and Hinkel, 2012; O'Neill and Burn, 2012). Ice enrichment continues over time by both incorporation of meteoric water as ice veins and lenses and expansion of ice-wedge networks, enhancing surface uplift of basin centres over centuries to millenia (Eisner and Peterson, 1998; Bockheim and Hinkel, 2012; Regmi et al., 2012).

On the Arctic Coastal Plain, Jorgenson and Shur 2007) noticed that differences in frost heaving between margins, dominated by coarse sediment, and centres, dominated by fine sediment, resulted in elevation differences of up to $4 \mathrm{~m}$, 
making the sandy margins of drained lakes long-lasting depressions in the landscape. They attributed this internal topography of drained basins to two causes: (1) differences in the thickness of thawed material available for frost-heaving under the shallow littoral terraces, where permafrost is sustained, versus the deeper lake centre, where a talik develops; and (2) sediment sorting and redistribution by wave action concentrating fine sediment with higher frost-heaving and frost-cracking potential near the lake centre (Jorgenson and Shur, 2007). In this chapter, we discuss geomorphological processes that can lead to the development of similar topography in drained basins where lakes have developed in fine glaciolacustrine sediment and lack littoral terraces. Specifically, we examine the influence of sediment redistribution during lake expansion and frost heaving during permafrost aggradation on the internal topography of these basins.

\subsection{Methods}

Relations between elevation, peat thickness, excess-ice content, ice-wedge distribution, and sediment stratigraphy were examined in three drained basins located in a tundra area of OCF to investigate controls on the internal topography

of drained thermokarst lake basins. A description of OCF is presented in Section 2.5 of this thesis. The following subsections describe how study sites were selected, and the methods used to assess lake-bottom conditions prior to drainage, relief and surface conditions in drained basins, basin floor stratigraphy and ice content, time since drainage, and approximate depth of frost penetration.

\subsubsection{Selection of study sites}

The study area is in a tundra portion of OCF containing over 30 distinct drained-lake basins (Fig. 6.1c). Basin size and orientation, as well as patterns of vegetation and water accumulation within the basins, were investigated using a 
combination of Landsat ETM images acquired on August $30^{\text {th }} 2001$ and aerial photographs taken between 1951 and 1996. Three drained lake basins were selected for detailed field study (Fig. 6.1.). These basins contain a range of relevant features and were accessible from the field camp at the E corner of Lake 1 (Fig. 6.1.).

\subsubsection{Lake-bottom conditions and shore recession prior to drainage}

Bathymetry and shore-recession rates were investigated in four lakes (Fig. 6.1k) near the three drained basins to establish conditions prior to lake drainage. Shore recession between 1951 and 2007 was determined using aerial photographs taken in 1951 and a SPOT 5 image from July 2007. The images were superimposed and co-registered using ice-wedge networks around the four lakes. Bathymetric surveys were conducted along transects in the four lakes using a sonar (Garmin GPSMAP 420s with dual frequency transducer) calibrated against measurements with a sounding line. For Lake 1, over 1000 depth measurements were collected and a bathymetric chart of the lake was produced by interpolating manually between these points. Depth measurements were separated by 10 to $100 \mathrm{~m}$, with higher sampling densities near the lake shores.

Wave base was estimated for wind speeds from the NE, SW, SE, and NW in lakes 1 and 4, the two largest lakes, for comparison with near-shore bathymetry. Mean wind speed was recorded near Lake 1 from June to August in 2008 and 2009. Wind speed (Onset Corp. S-WSA-M003, range: 0 to $45 \mathrm{~m} / \mathrm{s}$, accuracy: $\pm 1.1 \mathrm{~m} / \mathrm{s}$ or $4 \%$ of reading, resolution: $0.38 \mathrm{~m} / \mathrm{s}$ ) and direction (Onset Corp. S-WDA-M003, range: 0 to $355^{\circ}$, accuracy: $\pm 5^{\circ}$, resolution: $1.4^{\circ}$ ) sensors were mounted $2.25 \mathrm{~m}$ above the ground and connected to a 12 channel data-logger (Onset Corp U30-NRC-SYS-B, time accuracy: \pm 5 seconds per week). The recorded wind speed $\left(U_{r}\right)$ was adjusted to represent wind speed $10 \mathrm{~m}$ above the ground $\left(U, \mathrm{~ms}^{-1}\right)$ using Equation 6.1, where $y_{s}(\mathrm{~m})$ is the height of the sensor used to record observations 
Resio et al., 2002):

$$
U=U_{r}\left(\frac{10}{y_{s}}\right)^{1 / 7}
$$

Wind speed was then multiplied by 1.2 to approximate conditions over a small water body (fetch $<16 \mathrm{~km}$ ) (Resio et al. 2002). A representative fetch length $(F, \mathrm{~m})$ was defined for each direction in the two lakes based on shore location in 2001. The wave period $(P, \mathrm{~s})$ was estimated based on the maximum mean wind speed and fetch length using the Sverdrup-Munk-Bretschneider relation for deep water waves, where $g$ is the gravitational acceleration (Carper and Bachmann, 1984, Eleveld, 2012):

$$
\left(\frac{g P}{2 \pi U}\right)=1.20 \tanh \left[0.077\left(g \frac{F}{U^{2}}\right)^{0.25}\right]
$$

while insuring that the wave period did not exceed the limiting value $\left(P_{l}\right)$ for shallow water settings, where $d$ is the depth of water (Vincent 1985):

$$
P_{l}=9.78\left(\frac{d}{g}\right)^{\left(\frac{1}{2}\right)}
$$

Effective wave base was estimated to be half of the wave length, $W(\mathrm{~m})$ Carper and Bachmann, 1984; Resio et al., 2002, Eleveld, 2012):

$$
W=g\left(\frac{P^{2}}{2 \pi}\right)
$$

Samples of lake-bottom sediment were collected for texture analysis along a 200-m transect perpendicular to the NE shore of Lake 1 in order to examine relations between predicted wave base and sediment sorting along the basin floor.

\subsubsection{Relief, vegetation cover, and thermal conditions in drained basins}

In each basin, elevation was recorded using a transit and graduated rod along a transect extending from the paleoshoreline across the depressed margin and into the 
basin centre (Fig. 6.2). Relative elevation was recorded at intervals of 2 to $10 \mathrm{~m}$, with shorter measurement intervals used in steeper sections. Vegetation cover, including mean canopy height, relative abundance of trees, shrubs, forbs, graminoids and mosses, and ponding were described and photographed along the transect.

Temperature sensors (Onset Corp. TMC6-HA, range: $-40^{\circ} \mathrm{C}$ to $100^{\circ} \mathrm{C}$, accuracy: $\pm 0.5^{\circ} \mathrm{C}$ and resolution: $\pm 0.4^{\circ} \mathrm{C}$ at $0^{\circ} \mathrm{C}$ ) were installed beneath the permafrost surface at a depth of $1.25 \mathrm{~m}$ and connected to HOBO H8 data loggers (factory specified time accuracy: +45 to -60 minutes per year at $0{ }^{\circ} \mathrm{C}$ ) to record ground temperature every 4 hours in the margin and centre of each basin. In March 2010, snow depth was measured ten times within $10 \mathrm{~m}$ of each instrument to estimate the average thickness. Ten snow depth measurements were also repeated at 10-m intervals along a 100-m transect centred on the instrument to assess general snow conditions in basin centres and margins and determine representativeness of the instrumented site.

Peat-bottom materials from locations near the basin centres were collected for dating. Samples were collected from the top of the mineral soil at $10-\mathrm{m}$ intervals along 100-m sections of the transect to assess textural differences between basin margins and centres.

\subsubsection{Sediment texture and segregated ice content}

Samples of near-surface permafrost from boreholes up to $2.7 \mathrm{~m}$ below the ground surface were used to investigate differences in excess ice content between margins and centres, and to examine sediment stratigraphy. The boreholes were drilled with a CRREL core barrel to obtain profiles of ground materials in the margins and centres of basins 1 and 2. Eleven profiles were obtained from basin 1, most of which were located near the NE margin of the basin, and fourteen were obtained from

basin 2, most of which were located near the SW margin of the basin. Thaw depth was recorded at each drilling site in basin 1. Sedimentary and cryostratigraphic 


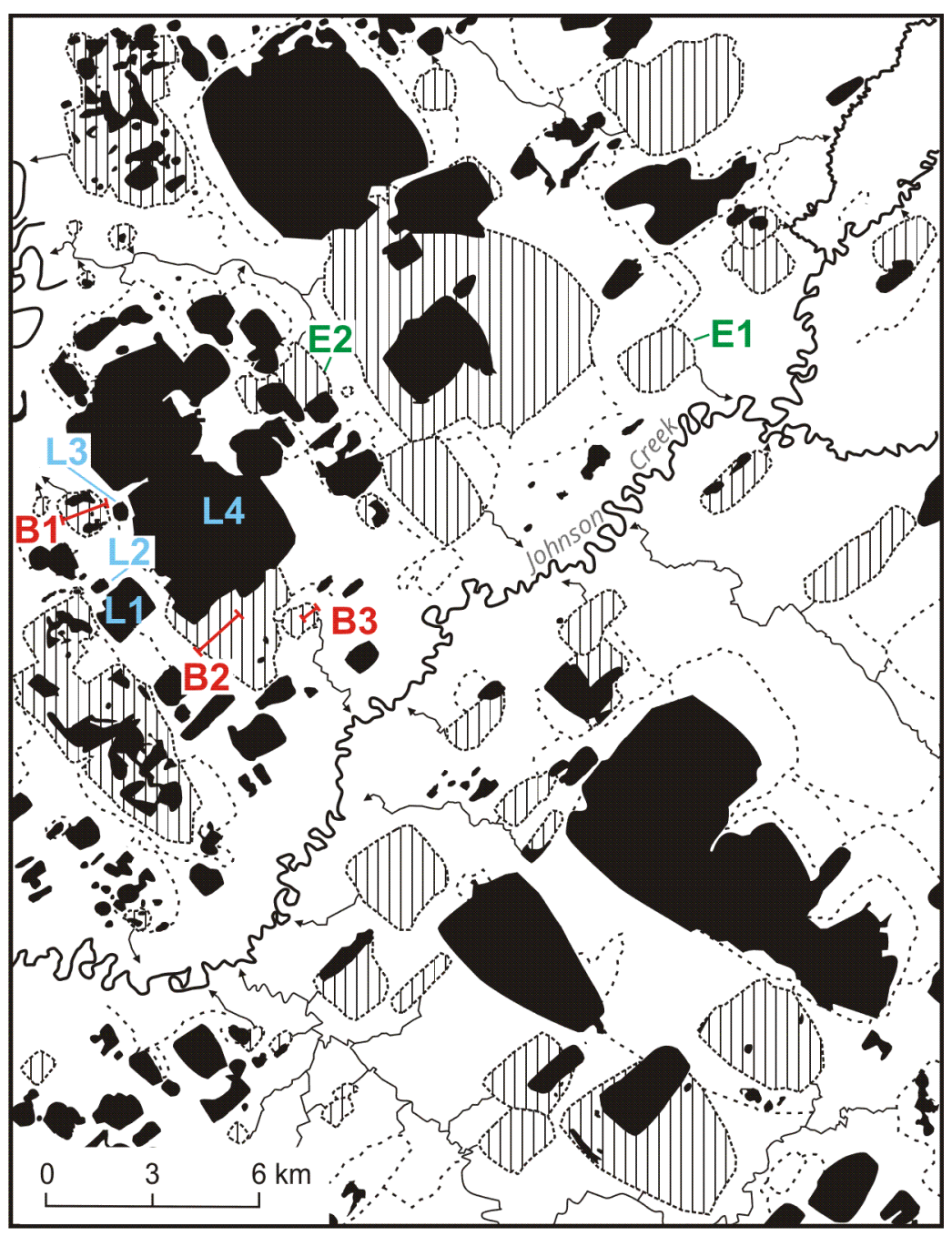

Figure 6.2: Lakes (black), drained basins (hatched), and paleoshorelines (dashed lines), in the area surrounding the basins selected for field study. Drainage outlets from the basins are shown with dotted lines. The three basins studied in the field, and the location of transects, are indicated in red (B1 to B3). The lakes surveyed in the field are indicated with blue numbers (L1 to L4). Green numbers refer to the example basins shown in Figure 3 (E1 and E2). The elongated basin SW of the study sites drained after 1972; all other basins drained before 1951. 
structures along the extracted core samples were photographed and described in the field. For logistical reasons, the samples were also thawed and initially processed in the field.

Core samples and mineral soil samples collected below the peat cover were analysed for excess ice content, moisture content, organic content, and sediment texture. Core samples were thawed, mixed, poured into beakers, weighed, and allowed to settle. Volumes of saturated sediment $\left(V_{s s}\right)$ and supernatant water $\left(V_{s w}\right)$ were recorded to provide a conservative estimate of the volumetric excess ice content $\left(I_{v}, \%\right)$ of the samples using Kokelj and Burn, 2003):

$$
I_{c}=g\left(\frac{1.09 V_{s w}}{V_{c}}\right) 100
$$

Core volume $\left(V_{c}\right)$ was measured in the field when the extracted core was intact and estimated in the laboratory using (Kokelj and Burn, 2003):

$$
V_{c}=V_{s s}+\left(1.09 V_{s w}\right)
$$

When the measured and calculated core volumes differed, the value yielding a lower excess ice content was used. Subsidence potential $(S P)$ was calculated for each core sample by multiplying sample length by $I_{v}$. $S P$ for a drill site was the sum of $S P$ for all its core samples.

Total water contents were determined by drying the sediments at $105^{\circ} \mathrm{C}$ and loss on ignition after four hours at $550^{\circ} \mathrm{C}$ was used as in indicator of organic contents Dean, 1974, Heiri et al., 2001). Sediment texture was determined using a Beckman Coulter LS 13,320 laser diffraction analyser fitted with a universal liquid medium sample chamber over a measurement range between 0.4 and $2000 \mu \mathrm{m}$ Neville et al., 2014). The samples were loaded into the machine until an obscuration level of $10 \pm 3 \%$ was reached and statistics were computed using the 
Fraunhofer diffraction model (Murray, 2002; Neville et al., 2014).

\subsubsection{Ice-wedge distribution}

Ice-wedge networks were mapped in the margin and centre of basins 1 and 2 using georeferenced vertical aerial photographs of the study area taken between 1974 and 1996, complemented by field notes and oblique aerial photographs. Ice wedges were also mapped around basin 1, over an area equivalent in size to the basin. Aerial photograph coverage of the study area was not complete for any given year, so basin 1 was mapped with photographs taken on June $15^{\text {th }}, 1996$ (1:50,000), whereas basin 2 was mapped based on aerial photographs taken on August $7^{\text {th }}, 1974(1: 60,000)$ and July $13^{\text {th }}, 1976(1: 60,000)$. Ice wedges were not mapped in basin 3 as it was only included in photographs taken on July $13^{\text {th }}, 1976(1: 60,000)$ and the quality of the image was not sufficient to identify ice wedge troughs with confidence. The boundary between depressed margins and basin centres was identified by examination of stereoscopic pairs of aerial photographs and Landsat 7 ETM images. Ice-wedge length per unit area was calculated in ArcGIS 10.2 using the spatial analyst extension.

\subsubsection{Time since drainage and depth of permafrost aggradation}

Time since drainage was investigated to determine the period available for development of vegetation, permafrost, and ground ice in each of the three basins. Aerial photographs indicated that the basins selected had been drained since at least 1951. The drainage date for each of the three basins was estimated based on ring counts of spruce trees collected from the basins, and radiocarbon dating of peat-bottom samples.

The depth of frost penetration in the centre of the drained basins was 
estimated with the Stefan solution (Burn and Smith, 1990):

$$
z_{t}=\sqrt{\frac{2 \lambda_{f} T_{p s} t}{L}}
$$

This model computes the thickness of permafrost $(z)$ based on time since the initiation of freezing $(t)$, mean annual temperature at the permafrost surface $\left(T_{p s}\right)$, thermal conductivity of the frozen ground $\left(\lambda_{f}\right)$, and volumetric latent heat of fusion $(L)$. The model assumes that (1) thermokarst lake drainage causes a step change in surface temperature; (2) ground thermal properties and water contents are homogeneous; (3) progression of the freezing front is downwards from the basin surface; and (4) the ground beneath the lake is uniformly at $0^{\circ} \mathrm{C}$, but unfrozen at $t$ $=0$. The Stefan solution is a robust model of ground freezing and thawing because the volumetric latent heat of fusion is at least one order of magnitude higher than the sensible heat components of the system (Mackay, 1973; Burn and Smith, 1990). The assumption of unidimensional frost penetration is acceptable for basin centres, where lateral freezing is negligible and most OCF lakes are sufficiently wide to be underlain by a through talik (Yukon Ecoregions Working Group, 2004). $\lambda_{f}$ and $L$ were calculated based on the mean moisture, organic, and mineral content of core 2.12 , extracted from the centre of basin 2. The thermal conductivity of frozen sediments $(\lambda)$ was calculated using a geometric mean (Johansen, 1977), with thermal conductivities of $0.56,2.24,0.25$, and $2.92 \mathrm{~W} \mathrm{~m}^{-1} \mathrm{~K}^{-1}$ for the water $\left(\lambda_{w}\right)$, ice $\left(\lambda_{i}\right)$, organic $\left(\lambda_{o}\right)$, and mineral $\left(\lambda_{m}\right)$ components, respectively (Williams and Smith, 1989). $T_{p s}$ was based on the average of $T_{p s}$ in basin centres during the study period, and an uncertainty range in the estimate of $z$ was defined based on the maximum and minimum $T_{p s}$ measured. 


\subsection{Results}

We examined conditions in thermokarst lakes prior to drainage as well as surface and subsurface conditions in drained basins to investigate the genesis of depressed basin margins in an area where sediment is fine and lakes lack littoral shelves. The following subsections present: 1) general drained basin characteristics in the study area; 2) bathymetry, wave base, and shore recession patterns prior to lake drainage; 3) time since drainage and estimated depth of permafrost aggradation in the drained basins surveyed in the field; 4) relief and surface conditions in the drained lake basins; and 5) near-surface ground-ice content and sediment stratigraphy in drained basin floors.

\subsubsection{Basin morphometry}

\section{Drained basins in the study area}

Thirty-eight drained basins with clear, complete outlines and several partial basins were identified in the study area $\left(889.3 \mathrm{~km}^{2}\right)$ (Fig. 6.2). The basins ranged in area from 0.2 to $40 \mathrm{~km}^{2}$ but the distribution was substantially skewed and $54 \%$ of the basins were less than $2 \mathrm{~km}^{2}$ in area. Only one basin was over $20 \mathrm{~km}^{2}$. Thirty of these thirty-eight basins were elongated, with twenty-one of the elongated basins oriented NE-SW and the remainder oriented NW-SE. All but one of the basins had drained by 1951. The remaining basin drained after 1972 (Labrecque et al., 2009).

The aerial photographs indicated that all but eight basins had wet, depressed margins and better drained centres. Some ponds occurred along depressed basin edges. The width of basin margins varied around the basins but, for more than half of the basins, the widest portion of the margin was, at least in part, along the SW shore (Fig. 6.1 k). There were low-centred ice-wedge polygons and ponding in ice-wedge troughs in many basin margins whereas in basin centres the polygons were commonly high-centred. Ice-wedge networks were generally better developed at 
the margin (Fig. 6.3a) but some basins had extensive and well developed ice-wedge networks both in their centre and at their margin (Fig. 6.3b). The latter had likely been drained for a longer period (Bockheim and Hinkel, 2012).

\section{Drained basins selected for field investigation}

The three basins selected for field investigation (Fig. 6.2 and 6.4) appeared to have drained and re-vegetated by 1951. Basins 1, 2, and 3 were 1.5, 5.9, and $0.6 \mathrm{~km}^{2}$ in area, respectively. The three basins had depressed margins. The centres of basins 1 and 3 were generally raised, but there were some ponds in the centre of basin 1 . Basin 3 was traversed by the deeply incised drainage channel of basin 2 (Fig. 6.4b). The centre of basin 2 was raised near the SW margin and had broad wet areas radiating from the drainage outlet, on the $\mathrm{E}$ edge, towards the centre and north side of the basin (Fig. 6.4b). Ice-wedge polygons in all three basins were poorly developed compared to the surrounding ground.

\subsubsection{Lake-bottom conditions and shore recession prior to drainage Bathymetry}

Bathymetric mapping in Lake 1 and transects in lakes 2, 3, and 4 confirmed that depressed margins and raised centres were not features of the lake bottom prior to drainage (Fig. 6.5). Detailed bathymetric mapping in Lake 1 indicated that the deeper portion of the basin was not centred but biased towards the SW (Fig. 6.5). Bathymetric profiles from lakes 2 to 4 also indicated deeper water towards the SW end of their basins (Fig. 6.5).

\section{Wave base}

The dominant winds during the 2008 and 2009 open water seasons were NE and, as a result, mean wave base was deepest near the SW end of the lakes (Table 6.1). A 

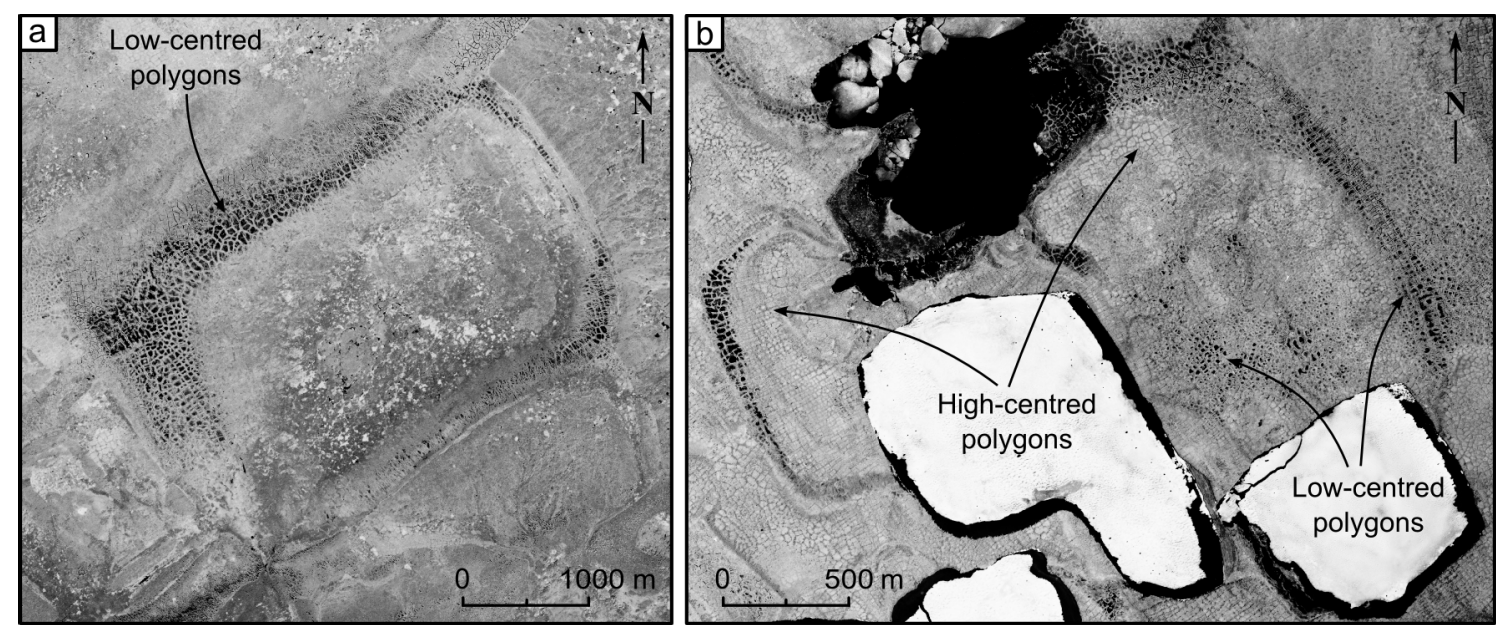

Figure 6.3: Two examples of drained basins shown on vertical aerial photographs taken on June 15th, 1996. Ice-wedge polygons are better developed (a) at the margin or (b) are extensive and well-developed both in the centres and at the margin. The widest part of the depressed margins (a) is near the west corner of the basin and (b) is difficult to determine because of basin and lake overlap. The upper lake in (b) is expanding into an area of polygons, as anticipated by the thermokarst lake cycle. Basin locations are indicated in Figure 2 (E1 and E2, respectively). 


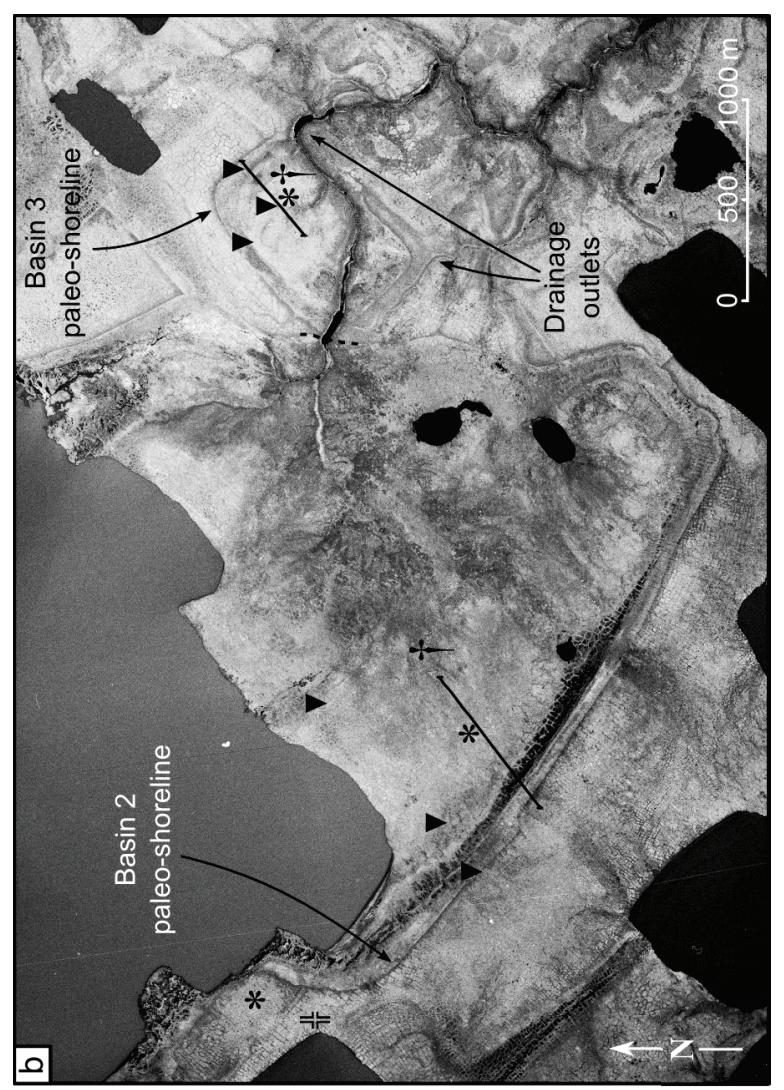

$\stackrel{8}{\oplus} \underset{0}{*}$

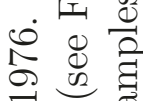

등

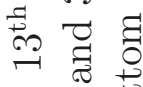

急次

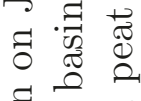

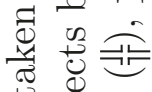

๓

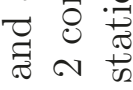

$\sim . \exists$

记

羟药

อ

긍

๘ี 80

๑.

-

许栗

品范

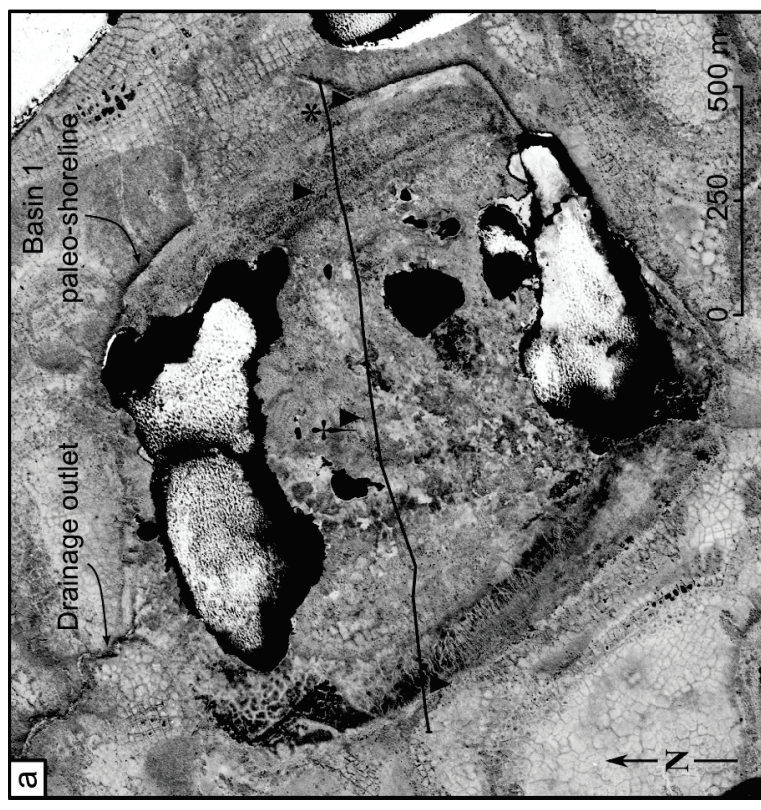

○)

거워

त्षै च

†

:

政 $\approx$

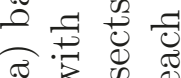

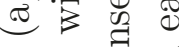

岮苛

पी

कृ.

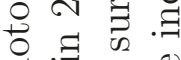

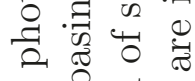

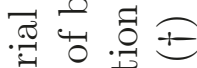

य

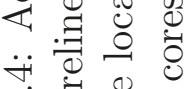

○ $0 \begin{aligned} & 0 \\ & 0\end{aligned}$

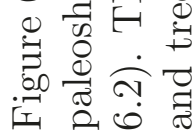




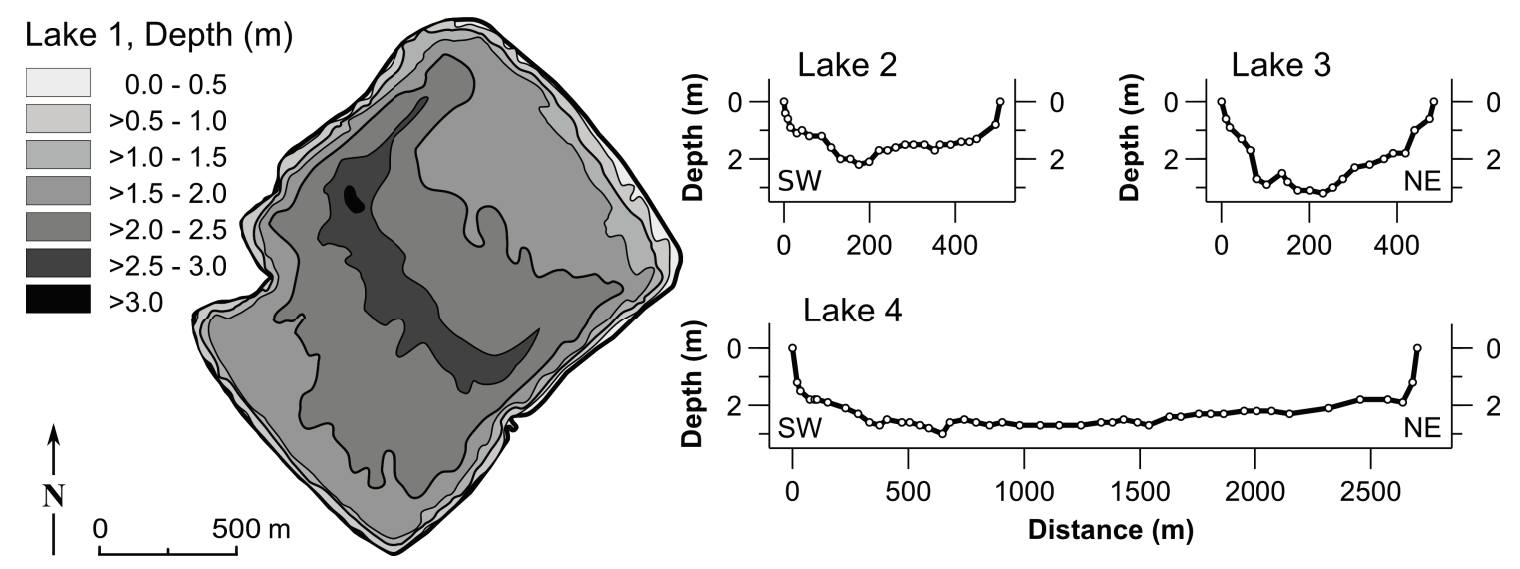

Figure 6.5: Bathymetric map of Lake 1 (left) and SW-NE profiles from three neighbouring lakes. Lake locations are indicated on Figure 6.2 (L1 to L4). 
comparison of wave-base estimates to near-shore bathymetry indicates that, despite deeper water near the SW end of the lakes (Fig. 6.5), the area where wave base reached the lake bottom extended further from SW than NE shorelines (Table 6.1). In all lakes, the area where wave base affected the lake bottom extended for the shortest distance from NW and SE shores. Hence the extent of lake bottom sediment likely to be re-suspended under mean wind conditions was greatest near the SW shores and least near the NW and SE shores.

\section{Sediment texture at the lake bottom}

The texture of lake-bottom sediment shifted from sandy loam to silt loam between 30 and $50 \mathrm{~m}$ from the NE shore of Lake 1, where lake depth increased to $1.0 \mathrm{~m}$ (Fig. 6.6). This is similar to estimates of the distance from shore where mean wave base reaches lake bottom (Table 6.1). Clay content was less than 5\% near shore, 5-10\% from 50 to $100 \mathrm{~m}$, and nearly $20 \%$ at $200 \mathrm{~m}$ from shore, where lake depth was near 2 m. Sand content decreased progressively from approximately $80 \%$ near shore to $<10 \%$ at $200 \mathrm{~m}$. The decrease in sand content and increase in clay content with water depth suggests a decreasing frequency of lake-bottom sediment re-suspension with distance from shore.

\section{Shore recession}

The highest rates of shore recession were measured in Lake 4 along NE-facing shore sections and near the $\mathrm{S}$ corner (Fig. 6.7). In Lake 1 rapid shore recession was concentrated along NE-facing shores and near the south corner, whereas the SW-facing shore was nearly static and had sections of beach aggradation (Fig. 6.7). High shore recession rates along shore with a NE-aspect are consistent with dominant winds from the NE during the open water season. This directional trend was not apparent in lakes 2 and 3, where shore recession rates were lowest. 


\begin{tabular}{|c|c|c|c|c|c|c|}
\hline Lake & Shore & Fetch $(\mathrm{m})$ & $U\left(\mathrm{~ms}^{-1}\right)$ & $W(\mathrm{~m})$ & $0.5 W(\mathrm{~m})$ & $D_{l b}(\mathrm{~m})$ \\
\hline \multirow{4}{*}{1} & SW & 1660 & 5.4 & 3.5 & 1.7 & 85 \\
\hline & $\mathrm{NE}$ & 1660 & 4.1 & 2.5 & 1.2 & 35 \\
\hline & $\mathrm{SE}$ & 1240 & 2.0 & 1.0 & 0.5 & $<10$ \\
\hline & NW & 1240 & 3.6 & 1.9 & 1.0 & 10 \\
\hline \multirow{4}{*}{2} & SW & 500 & 5.4 & 2.0 & 1.0 & 80 \\
\hline & $\mathrm{NE}$ & 500 & 4.1 & 1.5 & 0.7 & $<10$ \\
\hline & $\mathrm{SE}$ & 360 & 2.0 & 0.6 & 0.3 & $<5$ \\
\hline & NW & 360 & 3.6 & 1.1 & 0.6 & $<10$ \\
\hline \multirow{4}{*}{3} & SW & 490 & 5.4 & 1.9 & 1.0 & 25 \\
\hline & $\mathrm{NE}$ & 490 & 4.1 & 1.4 & 0.7 & 20 \\
\hline & $\mathrm{SE}$ & 500 & 2.0 & 0.7 & 0.3 & 0 \\
\hline & NW & 500 & 3.6 & 1.3 & 0.6 & $<10$ \\
\hline \multirow{4}{*}{4} & SW & 4130 & 5.4 & 5.1 & 2.6 & 525 \\
\hline & $\mathrm{NE}$ & 4130 & 4.1 & 3.7 & 1.9 & 310 \\
\hline & $\mathrm{SE}$ & 3950 & 2.0 & 1.5 & 0.7 & $<20$ \\
\hline & NW & 3950 & 3.6 & 3.2 & 1.6 & $<20$ \\
\hline
\end{tabular}

Table 6.1: Wave length $(W)$ and wave base $(0.5 W)$ calculated based on the mean wind speed $(U)$ recorded during the 2008 and 2009 open water seasons. The distance $\left(D_{l b}\right)$ from each shore where wave base reaches lake bottom sediment is based on comparisons of $0.5 \mathrm{~W}$ and bathymetric profiles. 

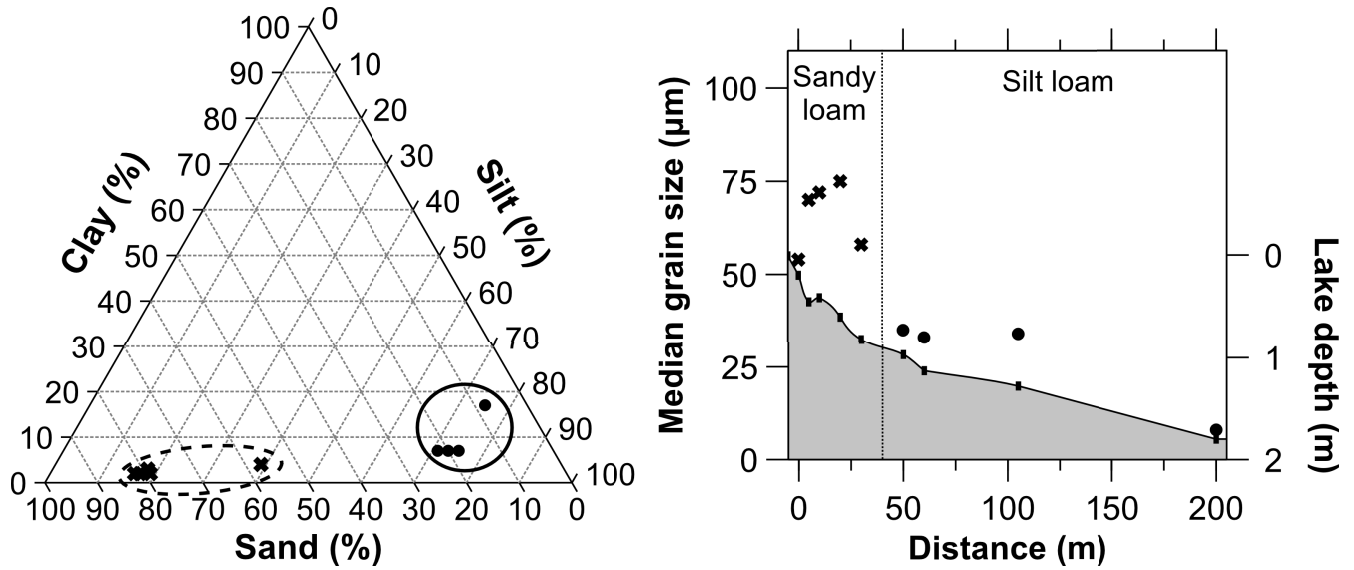

Figure 6.6: Lake-bottom sediment texture (left) and median particle size (right) along the bottom of Lake 1. Bathymetry is represented by the surface of the grey fill. Samples were assigned to the margins (x) or centre $(\bullet)$ of the basin based on clustering in the ternary diagram. 


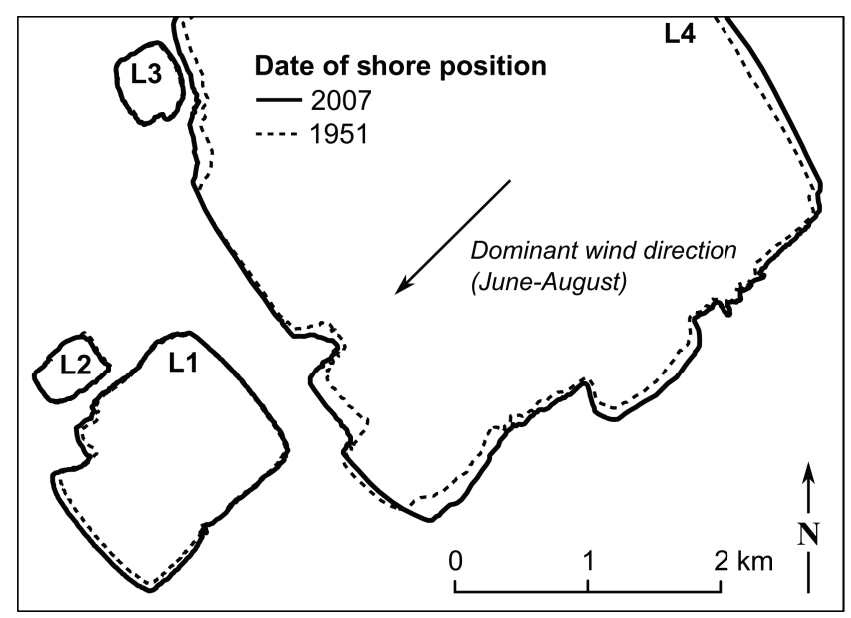

Figure 6.7: Shoreline position in 1951 and 2007 for lakes 1 to 4 (L1 to L4 on Fig. 6.2). Dominant wind direction during the open water season is indicated with an arrow. 


\subsubsection{Time since drainage and depth of permafrost aggradation}

The locations of tree cores and peat-bottom samples collected from the three basins are indicated on Figure 6.4. Tree cores dated to 1896, 1931, and 1900 by counting rings were collected in basins 1, 2, and 3 respectively. Dating of peat-bottom material yielded ages of $4065 \pm 20$ years (UCIAMS \# 142053) and $2175 \pm 20$ years (UCIAMS \# 67161) for two surfaces outside the basins, and $920 \pm 20$ years (UCIAMS \# 142052) in basin 2. Basin 3 was traversed by the deeply incised drainage channel of basin 2, indicating that basin 3 drained either prior to, or at the same time as basin 2. No peat bottom dates were obtained from basin 1 .

The Stefan solution was used to relate duration since drainage to depth of permafrost aggradation in basin centres. The parameters of the equation were derived based on the mean moisture, organic, and mineral content of core 12 extracted from basin 2 and are presented in Table 6.2. Results suggest that frost penetration would extend to a depth of $15( \pm 2)$ m after 100 years, and to a depth of $47( \pm 7) \mathrm{m}$ after 1000 years. After 4065 years, the age of the older surface dated near basin 2, permafrost thickness would be $94( \pm 13) \mathrm{m}$. The range of thicknesses presented in brackets is based on the range of $T_{p s}$ collected in basin centres in 2009-11 (Table 6.3.

\subsubsection{Topography}

The drained lake basins had variable internal relief (Fig. 6.8), but the mean elevations of the centres were higher than the mean elevations of the margins by 0.7 , 0.6 , and $0.8 \mathrm{~m}$ in basins 1,2 , and 3 , respectively. The maximum elevation difference measured between margins and centre was $2 \mathrm{~m}$, in basin 1 (Fig. 6.8). Basin centres were lower than the ground surrounding each former lake except close to the NE margin of basin 1, where a small portion of the basin centre exceeded the elevation of the shore bank by $0.2 \mathrm{~m}$ (Fig. 6.8). The mean elevation difference between the 

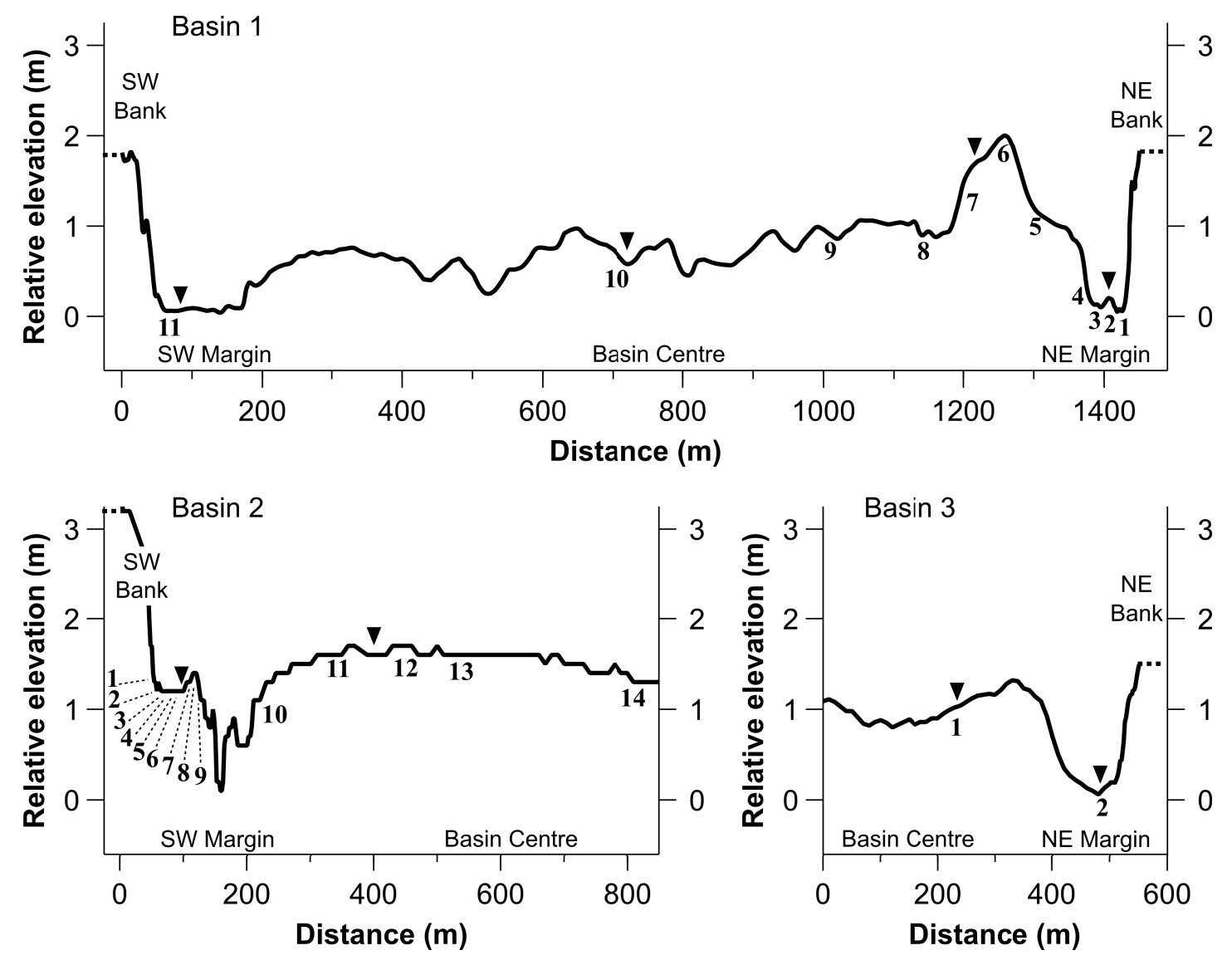

Figure 6.8: Relative elevation along transects in basins 1, 2 and 3. Drilling locations are indicated by numbers. Temperature sensor locations are indicated with triangles. Ground surface elevation was measured in relation to the lowest point along each transect, and is presented as a running mean with a window of $4 \mathrm{~m}$ on shore banks, in margins and transitions, and $20 \mathrm{~m}$ in the basin centre. 


\begin{tabular}{lc}
\hline Ice content $\left(\mathrm{m} \mathrm{m}^{-3}\right)$ & 0.73 \\
Organic fraction $\left(\mathrm{m} \mathrm{m}^{-3}\right)$ & 0.06 \\
$L\left(\mathrm{~kJ} \mathrm{~m}^{-3}\right)$ & $2.4 \times 10^{5}$ \\
$\lambda_{f}\left(\mathrm{~W} \mathrm{~m}{ }^{-1} \mathrm{C}^{-1}\right)$ & 2.08 \\
$T_{p s}\left({ }^{\circ} \mathrm{C}\right)$ & Mean: -4 \\
\hline
\end{tabular}

Table 6.2: Ground properties and thermal conditions used to simulate depth of permafrost aggradation in drained basin centres with the Stefan solution. 


\begin{tabular}{|c|c|c|c|c|c|}
\hline \multirow[b]{2}{*}{ Basin } & \multirow[b]{2}{*}{$\begin{array}{c}\text { Instrument } \\
\text { location }\end{array}$} & \multicolumn{2}{|c|}{$T_{p s}\left({ }^{\circ} \mathrm{C}\right)$} & \multicolumn{2}{|c|}{ Median snow depth (m) } \\
\hline & & 2009-10 & 2010-11 & at instrument & $\begin{array}{l}\text { in margin } \\
\text { or centre }\end{array}$ \\
\hline \multirow{4}{*}{1} & NE margin & -4.2 & - & 0.56 & $0.73[45]$ \\
\hline & SW margin & - & -0.7 & 0.43 & $0.23[70]$ \\
\hline & $\begin{array}{c}\text { Centre, } \\
\text { at core } 10\end{array}$ & -3.4 & -2.6 & 0.32 & $0.53[230]$ \\
\hline & $\begin{array}{c}\text { Centre, } \\
\text { near core } 7\end{array}$ & -2.7 & - & 0.74 & $0.53[230]$ \\
\hline \multirow{2}{*}{2} & SW margin & - & -2.6 & 0.17 & $0.24[35]$ \\
\hline & $\begin{array}{c}\text { Centre, } \\
\text { near cores } 11,12\end{array}$ & - & -2.6 & 0.17 & $0.24[35]$ \\
\hline \multirow{3}{*}{3} & NE margin & -2.8 & -2.7 & 0.67 & $0.63[85]$ \\
\hline & NW margin & - & -3.7 & 0.37 & $0.40[45]$ \\
\hline & $\begin{array}{c}\text { Centre, } \\
\text { near core } 1\end{array}$ & - & -4.5 & 0.22 & $0.29[109]$ \\
\hline
\end{tabular}

Table 6.3: Annual mean temperature at the permafrost surface $\left(T_{p s}\right)$ and snow depth in the margins and centres of basins 1 to 3 in 2009-11. Core numbers for each basin refer to Figure 6.8. Snow depth was measured in March 2010. Ten snow depth measurements were collected at each instrument but the total number of measurements in each margin and centre varied and is indicated in square brackets. 
bank top and the basin surface along the surveyed transects was $0.9,1.9$, and $0.6 \mathrm{~m}$ in basins 1,2 , and 3 , respectively.

\subsubsection{Vegetation, snow cover, and thermal conditions}

The vegetation of narrow margins, such as the NE margin of basins 1 and 3, was characterized by a sparse coverage of alder and willows (Alnus crispa and Salix spp., 1-m high) underlain by tussock-forming sedges (Carex spp.). In the wide NW margin of basins 1 and 2, Carex and Eriophorum spp. surrounded by standing water and floating mats of bog bean (Menyanthes trifoliata) extended more than $100 \mathrm{~m}$ from the bank foot. Vegetation in the centre of basins 1, 2, and 3 was patchy and varied with elevation and soil moisture conditions. In depressions, the vegetation cover was generally dominated by tussock-forming Carex and Eriophorum spp., with patches of dwarf birch (Betula glandulosa) and ericaceous shrubs, whereas raised ground was characterised by patches of alders (0.8 to $1.25 \mathrm{~m})$ with dwarf birch and willows (0.3 to $0.75 \mathrm{~m}$ ). Black spruce (Picea mariana) occurred in all three basin centres, but it was sparse in basins 2 and 3 and most abundant on the highest portion of basin 1, near the NE margin.

There was generally little snow cover in the SW margins (Table 6.3) where the extensive grassy vegetation did not prevent redistribution by wind. The snow pack was thicker at NE margins (Table 6.3) and associated with tall shrubs. Snow cover in basin centres varied with the structure of the vegetation. The centre of basin 1 , where patches of spruce and tall shrubs were abundant, had the thickest snow pack of the three basin centres (Table 6.3). In the centre of basins 2 and 3 there were extensive areas with low shrubs and tussocks where the snow cover was windblown and thin.

Nearly all ground temperature instruments were damaged by wildlife during the study (Table 6.3). Amongst the locations where data were successfully collected, annual mean temperature at the permafrost surface $\left(T_{p s}\right)$ varied between -2.6 and 
$-5.2^{\circ} \mathrm{C}$ in basin centres and between -0.7 and $-4.2^{\circ} \mathrm{C}$ at the margins (Table 6.3). These $T_{p s}$ are consistent with the range of ground temperatures previously reported from OCF (Roy-Léveillée et al. 2014). Thaw depth, measured in basin 1, was thinnest in the wet basin margins and thickest in the drier centre (Fig. 6.9a).

\subsubsection{Organic-layer thickness and texture at the top of mineral soil}

The elevation difference observed between basin margins and centres at the three sites was not due to variations in peat thickness. In basin 1, organic-layer thickness decreased with elevation (Fig. 6.9a), so that differences in surface elevation between the margin and the centre were less than differences in the level of mineral sediment by at least $0.5 \mathrm{~m}$. In basin 2 , where a smaller range of elevations was sampled, there was no clear relation between the elevation of the ground surface and the thickness of the organic layer (Fig. 6.9b).

Immediately beneath the organic layer, the mineral sediment textures were silt loam and silt-clay loam in basin centres, but loamy sand, sandy loam, and silt loam in basin margins (Fig. 6.10a, c, and d). The distribution of soil texture at the top of mineral soil in the three basins was similar to lake-bottom sediment texture in Lake 1 (Fig. 6.6). Mineral soils beneath the organic layer were generally coarser in basin margins than in the centres but median grain sizes for all margin samples were still $<125 \mu \mathrm{m}$ (Fig. 6.10b, d, and e) with very few particles $>250 \mu \mathrm{m}$ in diameter (less than $0.01 \%$ vol.).

\subsubsection{Excess-ice content and topography}

\section{Ice wedges}

Overall, ice-wedge polygons were best developed and most widespread in the margins and generally poorly developed and patchy in basin centres. Ice-wedge polygons in the margin of basin 1 were concentrated near the NE edge and in the W 


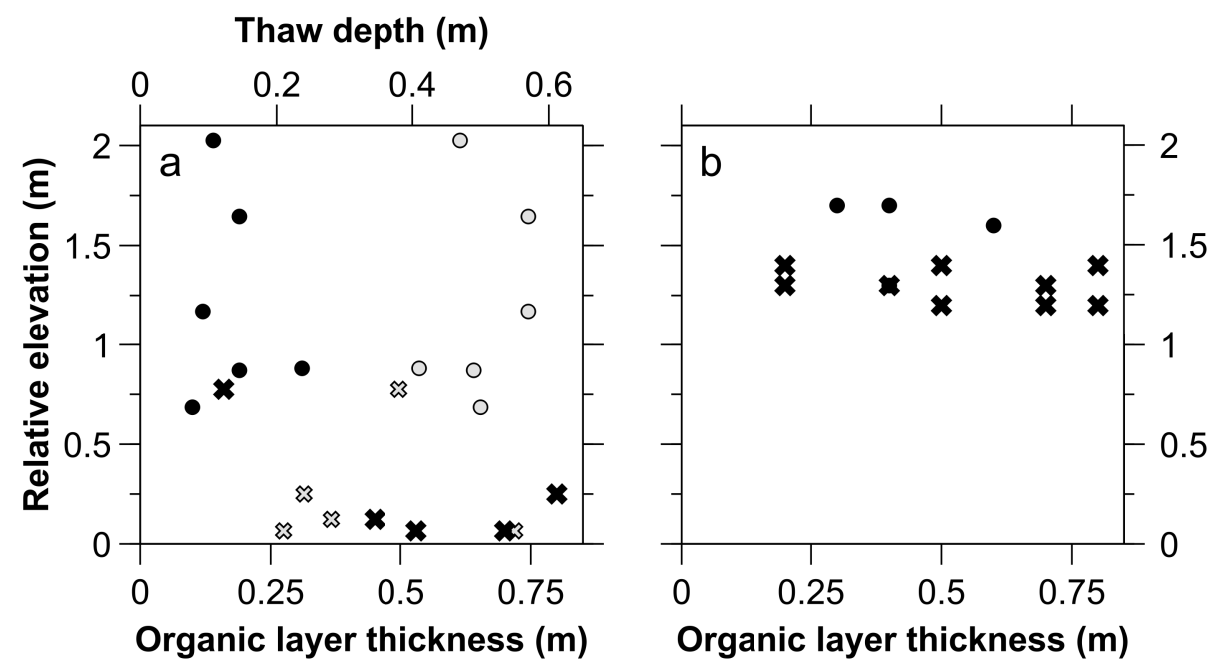

Figure 6.9: Ground-surface elevation plotted against organic-layer thickness (in black) and against thaw depth (in grey) in the margins (x) and centre (•) of (a) basin 1, and (b) basin 2 (see Fig. 6.8). Elevation was measured relative to the lowest point along the transect in each basin. 

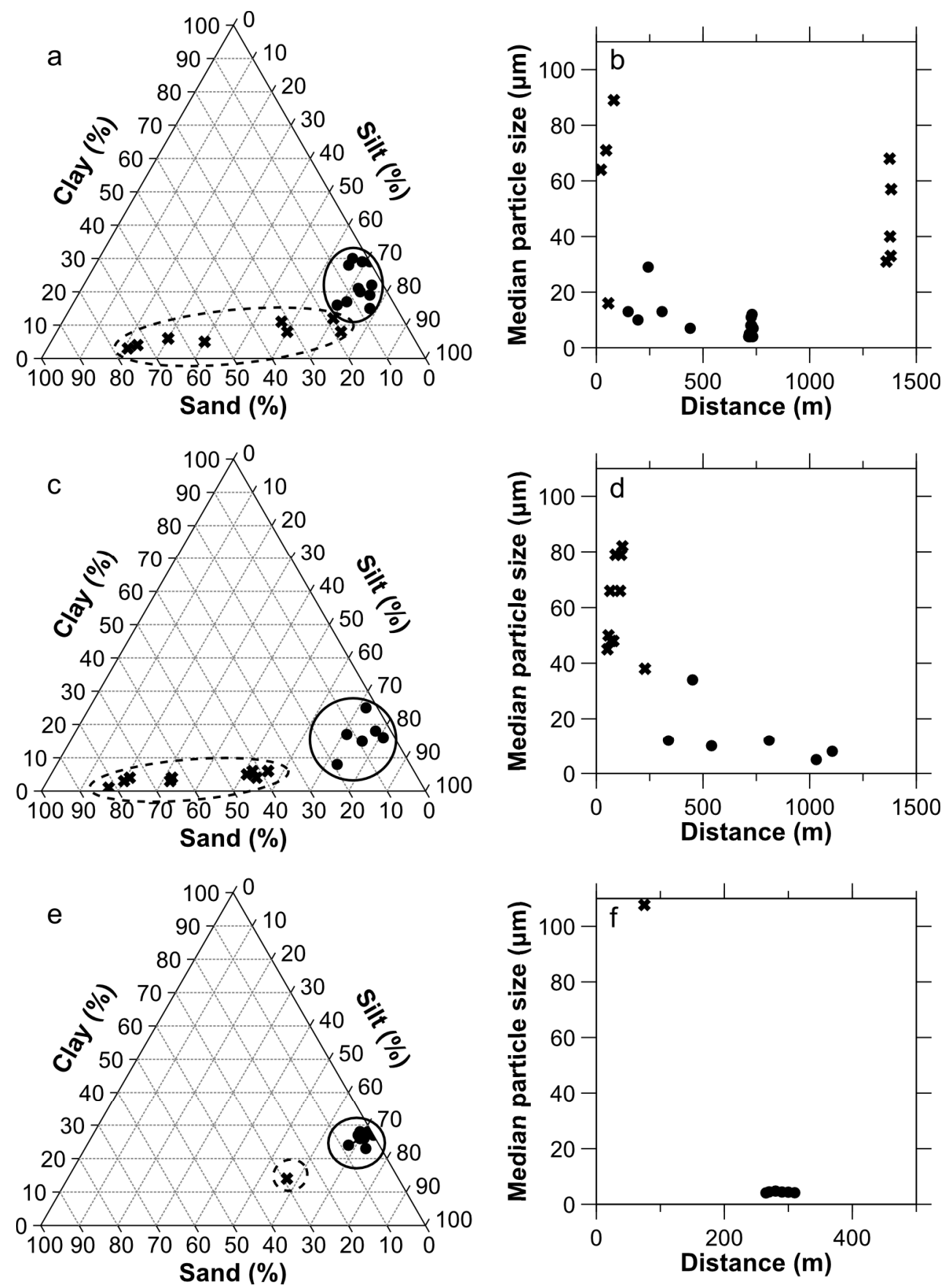

Figure 6.10: Sediment texture and median particle size at the top of the mineral soil in the margins (x) and centres (•) of basin 1 (a and b), basin 2 (c and d), and basin 3 (e and f) (see Fig. 6.8). Median particle size is plotted against distance along basin cross-sections, with a margin at both extremities of the transect in basin 1 . 


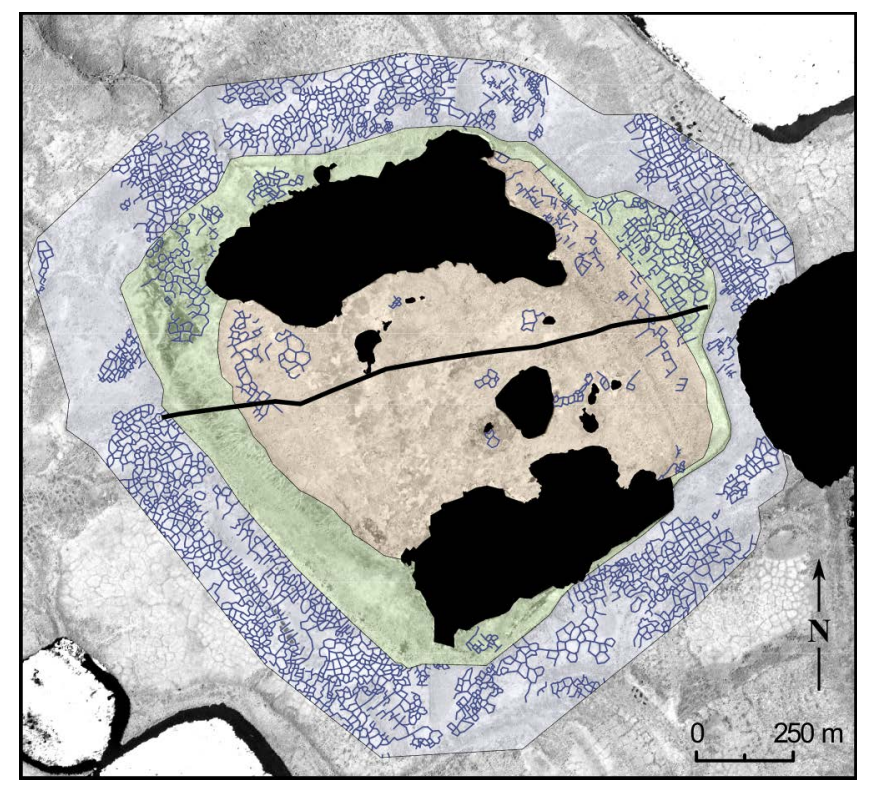

Figure 6.11: Distribution of ice-wedge troughs in and around basin 1. The basin centre and margin are shaded in orange and green, respectively. An area equal in size to basin 1 is shaded in blue around the basin. The location of the surveyed transect presented in Figure 6.8 is indicated with a black line. 
corner of the basin, where low-centred polygons were clearly visible on aerial photographs (Fig. 6.11). The mean length of ice-wedges per unit area (network density) in the margin of basin 1 was $22 \mathrm{~km} \mathrm{~km}^{-2}$, but in the basin centre it was 10 $\mathrm{km} \mathrm{km}^{-2}$. In comparison, the value for ground around the basin was $62 \mathrm{~km} \mathrm{~km}^{-2}$. In basin 2, orthogonal networks of low centred ice-wedge polygons extended along most of the SW margin, but some small polygon networks also occurred along the E margin. The ice-wedge network density in the margin of basin 2 was $19 \mathrm{~km} \mathrm{~km}^{-2}$, while in the basin centre it was $12 \mathrm{~km} \mathrm{~km}^{-2}$. Oblique photographs and field notes indicated that there were networks of ice-wedge polygons throughout basin 3. Most of the ice-wedge troughs constituting these networks were poorly developed.

\section{Segregated ice}

We examined subsidence potential in the top metre of mineral soil samples from basins 1 and 2 in order to assess the relations between sediment texture, organic-layer thickness, and excess-ice content, and to examine the role of differential frost heaving in the creation of depressed margins and raised centres. $S P$ approximates the elevation of the ground surface that is due to segregated ice present in the depth of ground considered.

There was no relation between median particle size and $S P$ in the sub-sample of profiles analysed from basins 1 and 2, indicating that other factors control excess ice content (Fig. 6.12a and b). We investigated the relation between $S P$ and organic layer thickness to assess whether development of the organic layer influences accumulation of excess, i.e. aggradational, ice in the upper layers of the permafrost. There was no clear relation between the thickness of the organic layer and $S P$ in the top two metres of mineral soil in either basin (Fig. 6.12c and d). In addition, there were no clear relations between $S P$ in the top two metres of mineral soil and the elevation of the mineral soil surface in either basin (Fig. 6.12e and f). Similar results were obtained when comparing elevation of the mineral soil surface to $S P$ in 

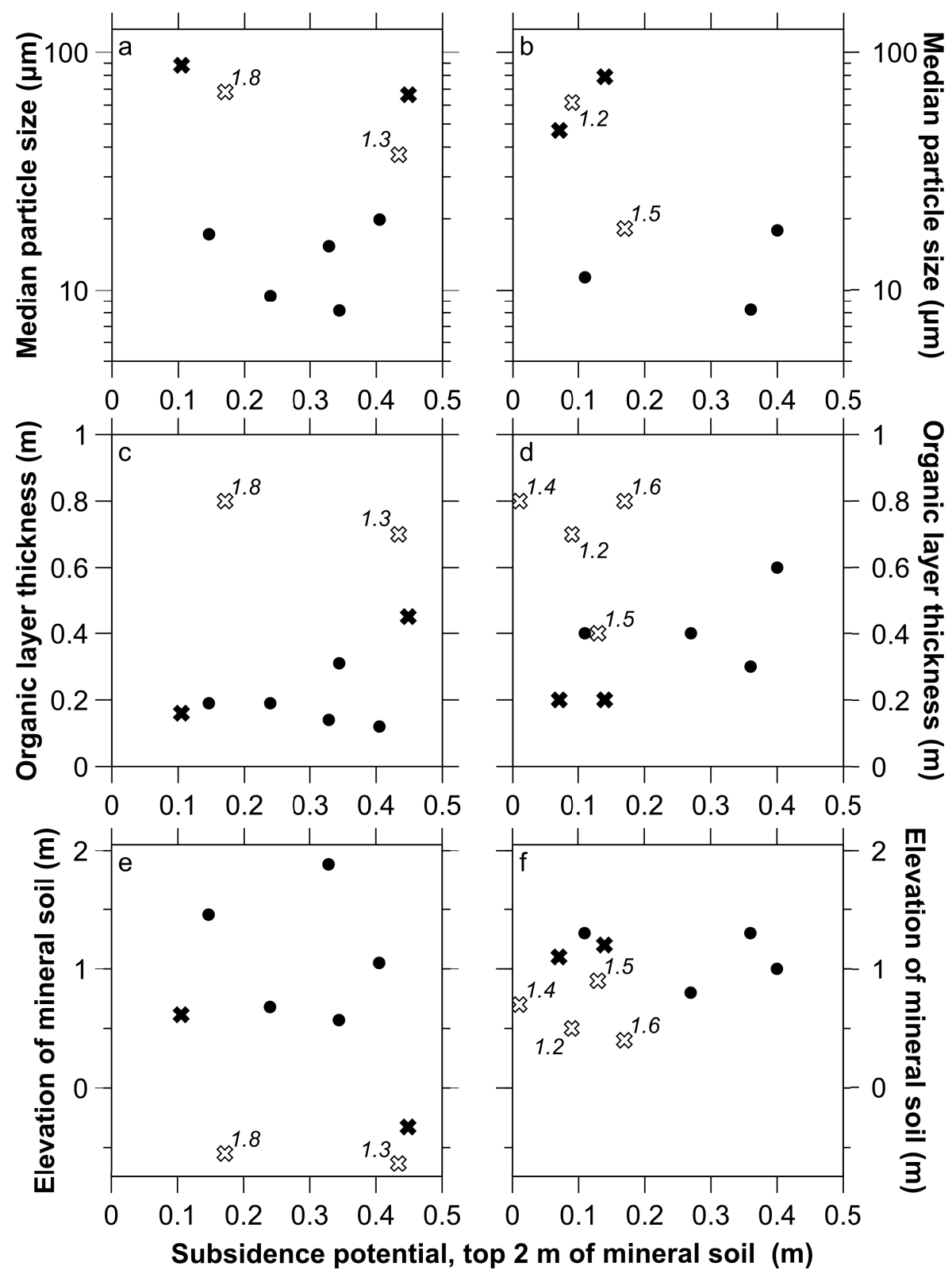

Figure 6.12: Subsidence potential due to thaw of segregated ice in the top 2 metres of mineral soil in margins $(\mathbf{x})$ and centres (•) of basin 1 (left) and basin 2 (right) plotted against (a, b) median particle size, (c, d) organic layer thickness, and (e, f) elevation of the mineral soil surface. Hollow symbols mark profiles extending less than $2 \mathrm{~m}$ beneath the organic layer and represent minimum subsidence-potential values. For these points, profile depth $(\mathrm{m})$ beneath the organic layer is indicated in itallics. Elevation of the mineral soil surface was determined at each drilling location by subtracting the thickness of the organic layer from the elevation of the ground surface relative to the lowest point along the transect. Texture analysis was only conducted on representative samples, hence the reduced number of data points in (b). 
the top 1 or $1.5 \mathrm{~m}$ of mineral soil, or in the entire cores to a depth of $2.5 \mathrm{~m}$. In basin 2, only a small range of elevations was sampled due to deep ponding in the depressed margin, but there was no relation between $S P$ and elevation (Fig. 6.12f).

\subsubsection{Core stratigraphy}

In the NE margin of basin 1, the top two metres of mineral soil consisted of sandy loam and loamy sand with varying amounts of organic material (Fig. 6.13). Organic material was commonly arranged in 1- or 2-cm layers of organic-poor and organic-rich sediment with a few larger masses. Segregated ice was abundant as veins and lenses up to $1 \mathrm{~cm}$ thick, and excess ice was distributed to depths exceeding $2 \mathrm{~m}$. In the centre of basin 1, the surface sediment was silt loam, underlain by a progressive transition to an assemblage of sandy loam and organic material similar in texture to the margin deposits (e.g., Fig. 6.13, cores 1.5 and 1.9). Where the basin centre elevation was greatest, however, silt loam extended to the bottom of the profile, near $2.5 \mathrm{~m}$ depth (e.g., Fig. 6.13, core 1.7). Excess ice was concentrated in the top $2 \mathrm{~m}$ of the profile in the centre of basin 1 .

In the margin of basin 2, there was an assemblage of loamy sand and organic material similar to that observed in the margin of basin 1, although slightly coarser grained (Fig. 6.14). The excess ice content in the bore holes was generally concentrated in these layers of fine sand, which were underlain by silt loam and silty-clay loam. The transition from sandy to silty sediment was abrupt in both texture and in cryostructure (e.g., Fig. 6.14, cores 2.2, 2.6, and 2.8), as the ice content was generally unstructured in the ice-rich loamy sand and formed fine ice

lenses in the silty sediment. Sediment in the basin centre consisted of silt loam with organic debris, sometimes organized in layers, to depths exceeding $2.5 \mathrm{~m}$ (Fig. 6.14). Excess ice was concentrated in the top $2 \mathrm{~m}$ of these sediments. 


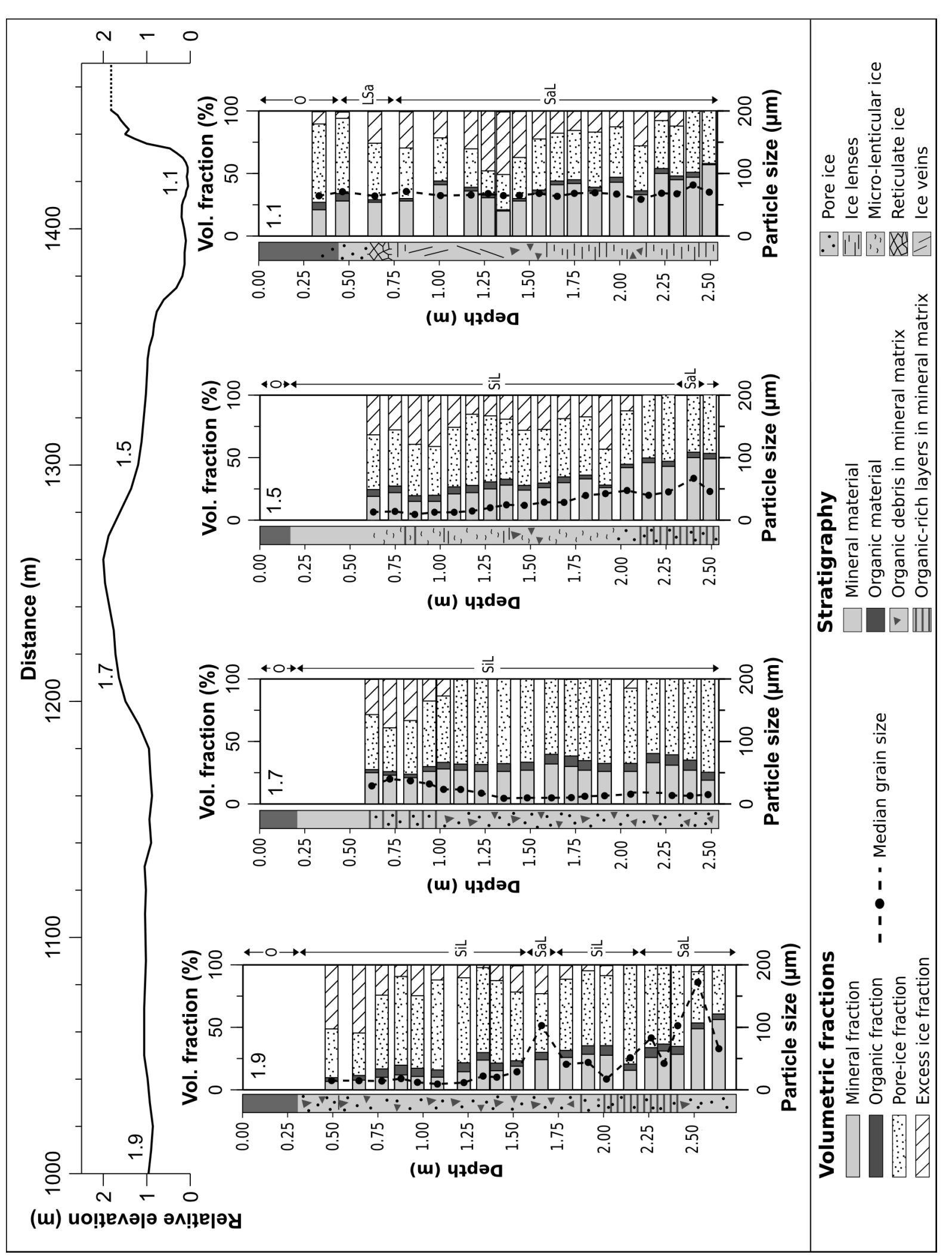

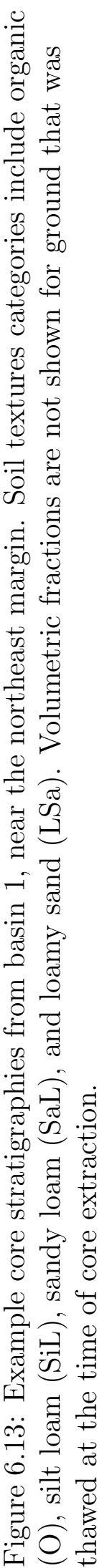




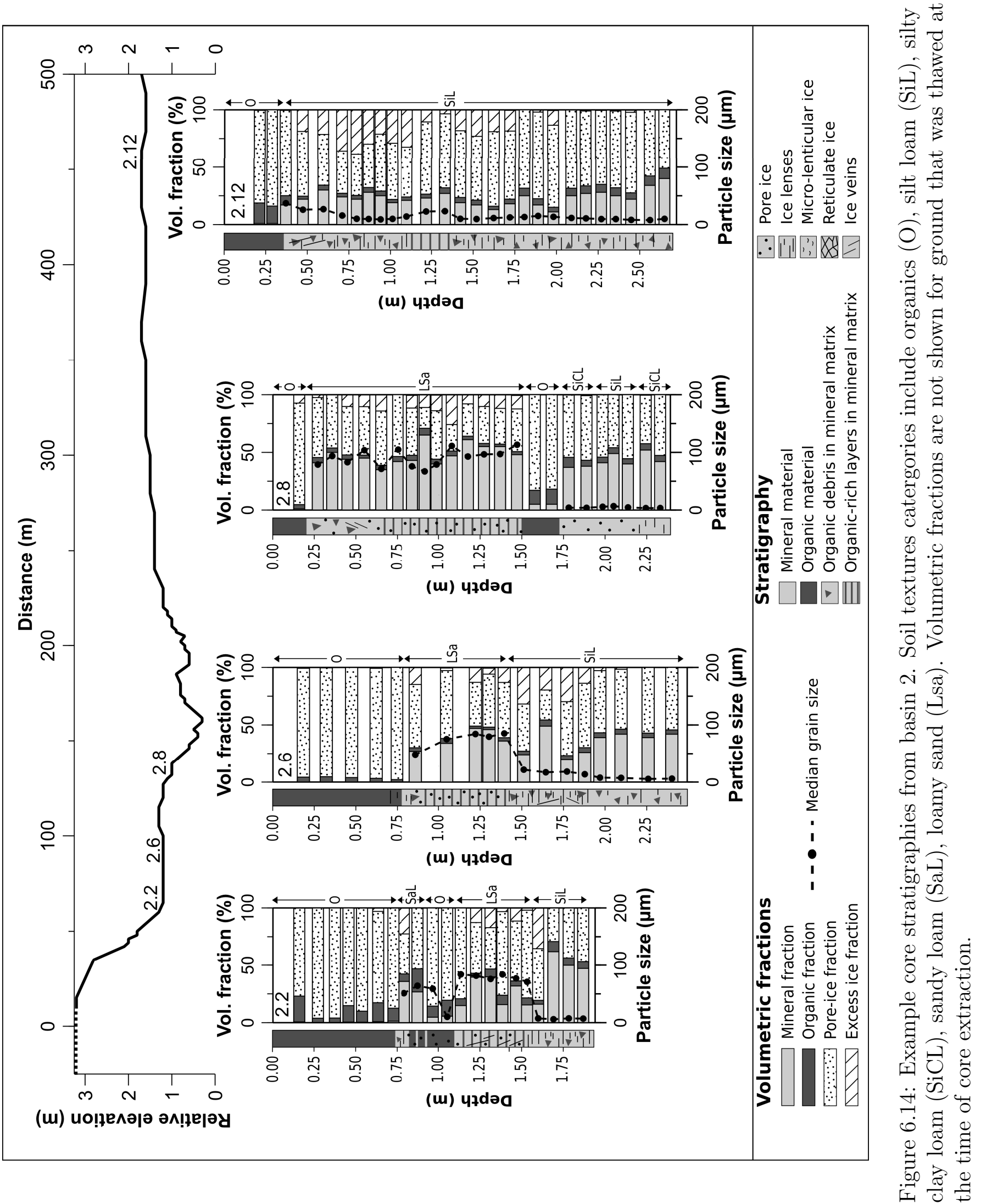




\subsection{Discussion}

Our aim through this work was to develop a conceptual model for the genesis of persistent depressed margins around raised centres in drained thermokarst lake basins of OCF. Previous explanations have focused on the poor frost-heave potential of gravelly sand, which may accumulate near shore in some regions, and on permafrost configuration beneath littoral terraces. The lakes of OCF lack littoral terraces and have developed in glaciolacustrine silts. Our working hypothesis was that the development of depressed margins and raised centres is not dependent on a frost susceptibility gradient along the lake bottom. The following paragraphs (1) compare field conditions associated with this topographic pattern in the OCF to conditions reported from drained basins in other Arctic lowlands; (2) suggest that ground ice is not the primary control on this topographic pattern; and (3) present an alternative model based on differences in volume of sediment deposited along the lake bottom which are revealed through re-freezing of the talik and heaving of the ground surface.

\subsubsection{Drained basin topography}

Bathymetric surveys in four lakes within the study area indicated that basins are deepest near the centre and shallowest near shore prior to lake drainage (Fig. 6.5), a pattern opposite to the internal topography of most drained basins in the study area. In the three drained basins surveyed in the field, the maximum elevation difference measured at the ground surface between the depressed margins and the raised centres was $2.1 \mathrm{~m}$ (basin 1, Fig. 6.8). The mean elevation difference between margins and centres in all three basins was less than $1 \mathrm{~m}$ (Fig. 6.8), although it was slightly over $1 \mathrm{~m}$ for the mineral soil below peat in basin 1. Near Prudhoe Bay, Liu et al. (2014) reported a peak to peak variation of only $0.6 \mathrm{~m}$ in a basin with wet margins around a centre with better drainage. Jorgenson and Shur (2007) presented 
an example where the mean elevation difference between the centre and margins is $2.7 \mathrm{~m}$. However they report a range of mean elevation differences varying from 0.7 to $2.7 \mathrm{~m}$ in the basins they surveyed, with elevation differences near or below $1 \mathrm{~m}$ in most basins (Jorgenson et al. 2003). These elevation differences are comparable to those of our study sites.

In all three basins, the sediments of the basin floor and underlying talik were below the level of the surrounding ground (Fig. 6.8), as a result of thaw subsidence during talik development. Once drained, ice-enrichment of aggrading near-surface permafrost may continue over millennia by ice-wedge development and increases in the segregated ice content Mackay, 1972; Bockheim and Hinkel, 2012, O'Neill and Burn, 2012). Ice-wedge troughs were more developed and polygon networks more extensive around the three drained basins surveyed than within them (Fig. 6.4). Ice-wedge network density around basin 1 was more than four times the density within the basin (Fig. 6.11).

The elevation difference between the bank top and the basin floor may also reflect incomplete freeze-back of the talik. Ice enrichment tends to be concentrated in the upper metres of permafrost (Jorgenson and Shur, 2007), but sediment expansion may also occur at depth as pore water freezes. The Stefan solution indicates that over 800 years would be required for permafrost to penetrate to a depth of $50 \mathrm{~m}$, suggesting that surface heaving due to refreezing of sediment may continue for centuries after drainage.

\subsubsection{Basin topography and excess-ice content}

\section{Ice-wedge distribution}

In the three basins surveyed, ice-wedge troughs were more developed and distributed more widely in basin margins than centres. Similar patterns were evident at several basins in the surrounding area (e.g., Fig. 6.3a). On the Arctic Coastal Plain, 
Jorgenson and Shur (2007) reported high wedge-ice volumes in the centre of basins with well-developed networks. But in younger basins, where ice-wedge polygons were less developed, they found a greater density in the margins than in the centres. The latter case is consistent with our observations in OCF (Fig. 6.3 a). The early development of ice wedges in the margins of drained basins on the Arctic Coastal Plain may be due to the re-activation of previous ice wedges preserved beneath shallow littoral terraces during lake expansion, as observed by Billings and Peterson (1980) near Point Barrow. In OCF, the lakes lack littoral terraces and talik development begins close to shore (see Ch. 5). It is unlikely that ice wedges would be preserved beneath such thermokarst lakes. However, ice wedges may develop first in parts of the basin where the talik freezes back soon after drainage, such as near shores where the talik is shallow Mackay, 1997; Mackay and Burn, 2002).

The high density of ice-wedge troughs in the margins of OCF basins indicates that variations in ice-wedge abundance are not necessary to the genesis of depressed margins. The ice wedges near the highest part of basin 1 may contribute to further elevating certain portions of the basin centre, but ice-wedge density in the margins of basins 1 and 2 was nearly twice that of the centres and ice-wedge troughs were generally better developed in the margins, suggesting that underlying ice wedges may be larger and, perhaps, older. Therefore, the distribution of ice wedges in drained basins of OCF may contribute to reducing the overall elevation difference between margins and centres rather than contributing to its genesis.

\section{Aggradational ice}

Downward water movement into permafrost is an important ice-enrichment mechanism for permafrost sediments (Cheng, 1983; Mackay, 1983). Aggradational ice develops when ice lenses at the bottom of the active layer are trapped in permafrost as sediment accumulation at the ground surface, peat growth, or thinning of the active layer, cause the permafrost table to rise (Mackay, 1972). At 
the Illisarvik drained lake site on Richards Island, O'Neill and Burn (2012) found that moisture availability in the active layer was the main control on ice enrichment at the top of permafrost.

In drained basins of $\mathrm{OCF}$, the ground surface has aggraded through development of the peat cover. There was no clear relation between excess ice content in the top two metres of mineral soil and organic-layer thickness in either basin (Fig. 6.12c and d), indicating that other factors control segregated ice content in these drained lake-basin sediments.

\section{Sediment texture and segregated ice}

The top of the mineral soil consisted of sandy loam and loamy sand in basin margins, and silt loam in the centres (Fig. 6.10). The gradual decrease in particle size away from the shore is consistent with previous observations of sediment textures in thermokarst lake basins due to sorting of sediment by wave action Britton, 1967; Murton, 1996; Jorgenson and Shur, 2007; Liu et al., 2014). In OCF, however, the coarse near-shore sediment of the basin margins had sand fractions consisting of very fine $(50$ to $100 \mu \mathrm{m})$ and fine $(100$ to $250 \mu \mathrm{m})$ sands, and median particle sizes $<125 \mu \mathrm{m}$. The 'coarse', near-shore sediment, winnowed from the silt loam input at the eroding lakeshore banks, was frost susceptible Andersland and Ladanyi, 2003).

In drained basins near Barrow, Alaska, Britton (1967) found that profiles of sediments at points along a line from shore towards the centre of a lake exhibited the same vertical gradation of materials as seen horizontally on the surface. This is consistent with sedimentation patterns in thermokarst lakes, where a basal layer of coarse, shallow-water sediment is eventually covered by a blanket of fines as the lake bottom subsides beneath wave base (Hopkins and Kidd, 1988; Murton, 1996, 2001). A sharp contact may mark the transition to sediment present prior to the expansion of the lake bottom over the area. Hopkins and Kidd (1988) described the deep 
water thermokarst sediment as sequences of organic silt layers separated by laminae of fine detrital organics.

Comparable stratigraphic patterns were visible in profiles from basins 1 and 2 . In the centre of basin 1, several profiles exhibited a downward coarsening sequence (Fig. 6.13). Near the SE shore of basin 2 the detrital basal layer, characterized by sandy sediment and occasional large peat debris, was less than $2-\mathrm{m}$ thick. An abrupt transition separated this sandy layer from the underlying silt loam (Fig. 6.13), which was of a texture similar to that of sediment around the lakes (see Ch.

5). We interpret this silt loam to be sediment deposited prior to lake expansion over the area.

There was no indication of a frost heave gradient between basin margins and centres (Fig. 6.12a and b) and no relation between excess-ice content in the top two metres of mineral soil and relative elevation of the ground surface in either basin (Fig. 6.12c and d), indicating that factors other than the amount of segregated ice in the upper layers of permafrost control elevation of the ground surface.

\section{The possibility of segregated ice at depth}

The maximum depth of sampling in this study was $2.7 \mathrm{~m}$ below the ground surface. Excess-ice content was concentrated in the top $2 \mathrm{~m}$ of the ground in the profiles examined but ice lenses were commonly observed in the lower sections of profiles despite the absence of excess ice, i.e., water from these lenses was absorbed into the soil matrix upon thawing (Burn, 1990). Such ice lenses were observed in the lower sections of most profiles from the margins and centre of basins 1 and 2. This suggests that ice segregation may occur during penetration of the freezing front beyond surface layers, despite reduced moisture availability. However it is unlikely that the genesis of depressed margins is due to a frost-heave gradient at depth between basin margins and centres, as the gradient in sediment texture observed at the surface is not replicated at depth beneath the basin floor (Fig. 6.13 and 6.14) 
Hopkins and Kidd, 1988; Murton, 1996)). Moreover the permafrost preserved at depth beneath the lake margins (see Ch. 5) predates the lake basin and, hence, aggraded under conditions unrelated to the basin configuration.

\subsubsection{Sediment available for frost heaving}

In the lakes of the Arctic Coastal Plain, Jorgenson and Shur (2007) note that permafrost is sustained beneath shallow sandy littoral terraces while a deep talik underlies the lake centre. Hence, near the basin margins, only the base of the sandy active layer refreezes after drainage, and the small amount of segregated ice that forms with permafrost aggradation may be sufficient to heave the surface only a few centimetres. In OCF, where lakes are pan-shaped and lack littoral terraces, talik development begins close to the receding shoreline and talik depth tends to increase with the square root of distance from shore (Burn and Smith, 1990). Permafrost may be sustained beneath an active layer for a short distance $(<10 \mathrm{~m})$ away from the shore, but this talik 'margin' is not comparable in scale to the margins of drained basins which commonly extend more than $100 \mathrm{~m}$ from the former shore (Fig. 6.1 c, Fig. 6.3a, and Fig. 6.8). As a result, there is little apparent relation between the geometry of taliks and the topography of drained basins in OCF.

Regardless of talik geometry, an increase in talik depth away from the shore does not by itself represent an increase in the amount of sediment that will be in permafrost once refreezing is complete, as original permafrost is preserved beneath the talik boundary. There will be an increase in the total amount of sediment affected by frost heaving in the basin centre if sediment is transported towards the basin centre and deposited there. Such a redistribution of sediment occurs during lake expansion, when eroded bank material is sorted, transported, and deposited on the lake bottom. The coarser fraction of the sediment may accumulate near shore if the wave base reaches the lake bottom and the fines are resuspended. Over time, as the lake bottom subsides beneath wave base and the shore continues to recede, a 
blanket of fine sediment accumulates over the layer of coarse sediment that was deposited near shore Hopkins and Kidd, 1988, Murton, 1996, 2001). Hence less sediment is deposited near shore than near the centre of expanding thermokarst lakes, where water is deeper and sediment deposition occurs over a longer period.

In the glaciolacustrine deposits of OCF, differences in the amount of sediment deposited near shore and in the basin centre may be accentuated by the fine texture of the sediment input from the eroding banks. Only a very small fraction of the sediment is sufficiently coarse to accumulate near shore, resulting in a thin basal layer of coarse sediment, whereas most of the input sediment is easily resuspended and ends up away from the shoreline, contributing to the blanket of fine sediment deposited in deep water.

Redistribution of sediment during lake expansion does not result in a convex lake bathymetry in OCF, because increasing deposition is associated with the progressive subsidence of the lake bottom, particularly within $60 \mathrm{~m}$ of the shore (Fig. 6.5) (see Ch. 5). However the difference in sediment volume is revealed by heave as permafrost re-establishes in the exposed sediment and underlying talik after drainage. We propose that the reduced quantity of sediment deposited beneath the shallow water of the lake margin, where wave action causes the re-suspension and removal of silts and clays from the lake bottom, is the fundamental cause of depressed margins in the drained lake basins of OCF.

\subsubsection{Model for the internal topography of drained basins in Old Crow Flats}

This component of the thesis aimed to develop a model for the genesis of persistent depressed margins around raised centres in drained thermokarst lake basins of OCF. Whereas the model proposed by Jorgenson and Shur (2007) for the drained basins of the Arctic Coastal Plain cites the development of a frost-heave gradient in the lake bottom sediment and the effects of littoral terraces on talik geometry as the 
main cause for the elevation difference, our model is based on patterns of sediment deposition near receding thermokarst shorelines and differences in the volume of sediment deposited in the basin margin and centre. Hence, similar to what was proposed by Jorgenson and Shur (2007), we suggest that the processes critical to the genesis of depressed margins in drained lake basins take place during the lake expansion and permafrost recovery phases of the thermokarst lake cycle (Fig. 6.15).

In the tundra of OCF, the expansion phase of thermokarst lakes is associated with: (1) recession of eroding shore banks due to heat-conduction from the lake into the surrounding permafrost, thermodenudation of thawing bank sediment, and wave erosion of slumped sediment and exposed permafrost at the bank foot Roy-Léveillée and Burn, 2010); (2) initiation of talik development beneath the newly submerged ground, causing the progressive subsidence of the lake bottom (see Ch. 5); (3) accumulation of sands and pieces of peat beneath shallow water near the receding shore banks, where wave base reaches lake bottom and causes re-suspension of silts, clays, and fine grained organic matter; and (4) accumulation of fine sediment where the lake bottom is beneath wave base (Fig. 6.15a). After drainage, permafrost recovery is associated with: (5) permafrost aggradation in the exposed lake-bottom sediment and talik refreezing; and (6) heaving of the ground surface due to ice segregation and pore water expansion, revealing differences in the quantity of sediment deposited along the basin floor (Fig. 6.15b). The topography caused by this difference may be accentuated if there is a clear gradient in sediment frost-susceptibility increasing towards the lake centre, or if ice wedges develop preferentially in the lake centre. We did not find evidence of these two latter conditions at the basins surveyed in OCF.

\subsubsection{Controls on the width of depressed margins}

The width of the shallow water deposition zone is determined by how far from shore sediment re-suspension can occur, and thus by near-shore bathymetry and wave 

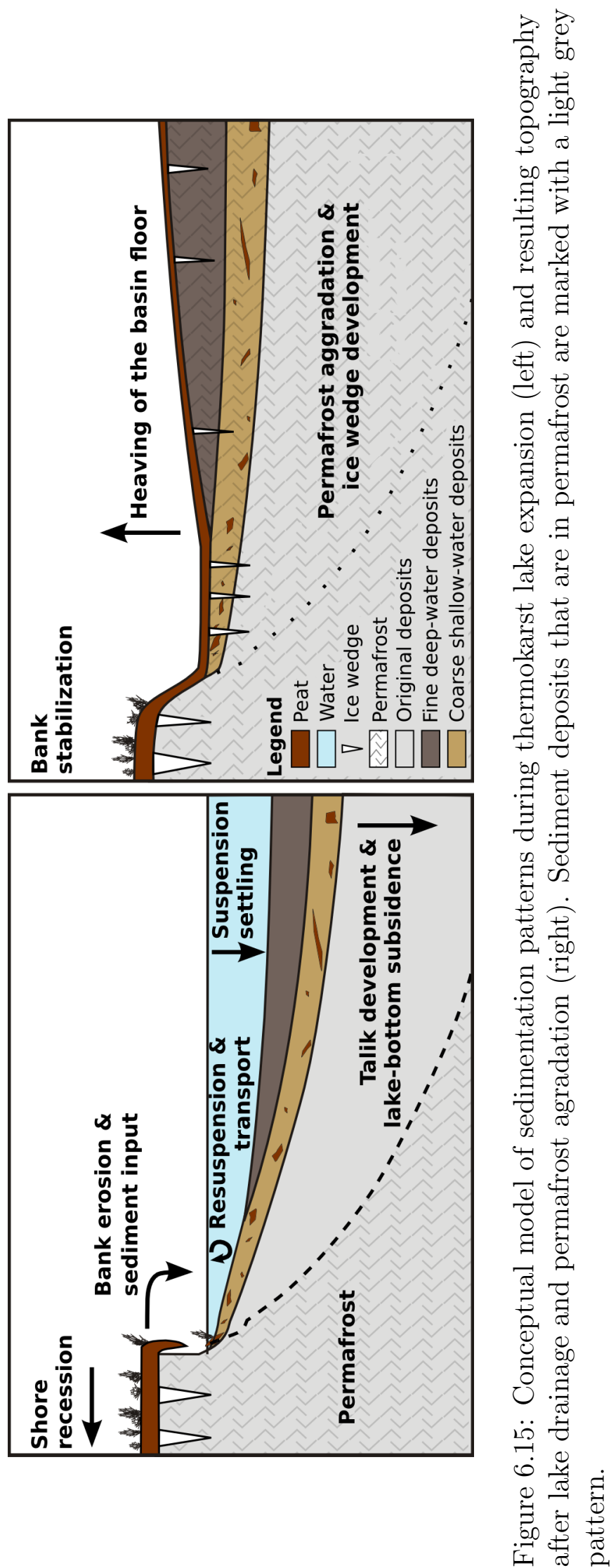
base. Wave base is controlled by wind regime and fetch (Davidson-Arnott, 2010), whereas near-shore bathymetry is controlled by rates of shore recession and thaw subsidence of the lake bottom (see Ch. 5), as well as erosion of the lake bottom sediment by wave action (Davidson-Arnott, 2010). Wave base will be greatest downwind along the dominant wind direction, NE in OCF, and will increase with fetch (Table 6.1). Lake shores facing NE had high rates of shore recession where fetch was over $1 \mathrm{~km}$ (Fig. 6.7), resulting in a shallow talik slope and reduced thaw subsidence for an extended distance from shore (see Ch. 5). However, despite the limited thaw subsidence of the lake bottom associated with the shallow talik slope,

the lake-bottom near the rapidly receding shores in Lake 1 was steep (Fig. 6.5) (see Ch. 5), suggesting that erosion of lake-bottom sediment may occur at this end of the lake. These factors create conditions favourable to the development of a wide zone of sediment re-suspension near shores facing NE, thus wide depressed margins near these shores after lake drainage and frost heaving of the lake-bottom. This is consistent with our observation that the widest portion of the margin was, at least in part, along the SW shore for the majority of the drained basins within the study area.

\subsection{Summary and conclusions}

Drained thermokarst lake basins are widespread in Arctic lowlands. In tundra areas, the internal topography of these basins often constitutes a wet, depressed margin surrounding a slightly elevated, better drained centre. In this chapter, we examined the influence of sediment redistribution during lake expansion and frost heaving during permafrost aggradation on the internal topography of these basins. Our specific research objectives were to: (1) examine surface conditions in three drained basins in a tundra area in OCF, (2) compare the model used to explain the internal topography of drained basins on the Arctic Coastal Plain of Alaska to conditions in 
the margins and centres of OCF drained basins, (3) propose a modified landform development model for the internal topography of drained basins that is adapted to conditions similar to those found in $\mathrm{OCF}$.

Our main findings were that:

1. Drained basins with depressed margins and raised centres in a tundra area of OCF exhibit a topographic pattern similar to the Arctic Coastal Plain.

2. Ice-wedge density in basin margins was nearly twice that in the centres, suggesting that, contrary to the Arctic Coastal Plain, the distribution of ice wedges may contribute to reducing the overall elevation difference between basin margins and centres rather than contributing to its genesis.

3. There was no relation between excess-ice content in the top two metres of mineral soil and relative elevation of the ground surface.

4. Sediment stratigraphy in the top $2.75 \mathrm{~m}$ of the ground indicated that greater volumes of sediment are deposited in the basin centre than at the basin margin during lake expansion. We propose that this difference in sediment volume, revealed by frost heaving after lake drainage, is the main mechanism responsible for the genesis of depressed margins and raised centres in drained basins. 


\section{Part III}

\section{Concluding chapters}




\section{Chapter 7}

\section{Summary, implications, and future work}

\subsection{Introduction}

This thesis has contributed to an improved understanding of thermokarst lake dynamics and permafrost conditions in Old Crow Flats, Yukon. After a general assessment of permafrost temperatures in the Old Crow area, lake-bottom temperatures and talik geometry were examined near receding shorelines, and controls on talik initiation and development were investigated numerically. Relief, stratigraphy, and near-surface ground ice were examined near the shore banks of drained lake basins to investigate why lake margins become persistent low features in the landscape after lake drainage and permafrost recovery. The dynamics of shore recession, talik development, and sediment deposition were then integrated in a conceptual model of landform development for the topography that develops in drained lake basins after refreezing of the sub-lake talik.

The following sections revisit the three primary research objectives of this thesis, summarize key findings and, where applicable, highlight gained insights which may have implications beyond OCF. Finally, some directions for future research are presented.

\subsection{Summary of findings and significance}

\subsubsection{Permafrost temperatures in the Old Crow area}

The first objective of this thesis was to examine spatial variation in ground

temperatures within the forest-tundra ecotone near Old Crow. The working 
hypothesis presented was that within the patchy vegetation assemblage of the forest-tundra ecotone in $\mathrm{OCF}$, ground temperatures decline with decreasing height of the vegetation, creating a heterogeneous ground temperature field.

Field results indicated that, indeed, ground temperature generally decreases across treeline from the taiga to the landscapes dominated by low shrubs and sedges. Permafrost temperature at the depth of zero annual amplitude was -3.1 to $-4.0^{\circ} \mathrm{C}$ in the taiga along Porcupine and Old Crow rivers, and varied between $-5.1^{\circ} \mathrm{C}$ beneath low shrubs and $-2.6^{\circ} \mathrm{C}$ beneath tall shrubs on the Flats. These temperatures compare with permafrost temperatures measured in or near the forest-tundra ecotone in central and western Canada, Alaska and eastern Siberia.

The spatial variability of mean annual permafrost temperatures beneath the heterogeneous vegetation cover of the forest-tundra transition appears to be controlled by the snow-holding capacity of vegetation at the local scale and the spatial configuration of land covers in the mesoscale landscape, which controlled snow supply. Hence, the largest range of mean annual permafrost temperatures was encountered where the snow supply was not limited by the presence of extensive taiga. In these areas, snow depth was correlated with vegetation height and thus the deepest snow and warmest permafrost temperatures were in small, isolated patches of trees. Our working hypothesis was supported in the latter setting, but not where taiga patches were sufficiently large and dense as to interfere with snow redistribution by wind. In the latter case, wind-blown snow was trapped at the patch edge and ground temperatures were lower within taiga patches than in the surrounding shrubs.

This component of the thesis helps understanding the structure of spatial variation in ground temperature beneath the heterogenous vegetation cover of the forest-tundra ecotone. Understanding this spatial variability is necessary for effective sampling schemes and to assess the representativeness of point data when evaluating the thermal state of permafrost in an area. Such evaluations are commonly required 
for the environmental impact assessments of northern projects and are used for the evaluation of models predicting climate-induced changes in the global extent of permafrost (e.g. Burn and Nelson, 2006). The results indicate that measurements in landscape units defined based on both the local vegetation height and the structure of the surrounding ecological and physical environment are required to capture the natural spatial variability of permafrost temperatures in the forest-tundra ecotone.

\subsubsection{Talik development near thermokarst shores}

The second objective of this thesis was to examine talik development near thermokarst lake shores. This component of the research aimed to assess whether approaches used to predict permafrost degradation beneath thermokarst lakes of the Mackenzie Delta area and central Yukon (Burn and Smith, 1990; Mackay, 1992, Burn, 2002) are effective in OCF, and to investigate discrepancies using a numerical model.

Field observations indicate that rules of thumb developed to predict talik initiation in the Mackenzie Delta area (Mackay, 1992) are not effective in OCF, as taliks were found under water depths of as little as $20 \mathrm{~cm}$, considerably less the maximum winter ice thickness $(1.5 \mathrm{~m})$. Mean annual lake-bottom temperatures were above $0^{\circ} \mathrm{C}$ beneath shallow water that froze to the lake bottom in early winter due to high summer temperatures and near-shore snow drifts trapping latent heat, released from the lake bottom during winter. Talik development was approximated effectively using the Stefan solution (Burn and Smith, 1990) where seasonal freezing and thawing of the lake bottom was limited in duration by shore recession rates and bathymetry. However talik shape was irregular where seasonal freezing and thawing of the lake bottom was extensive in space and prolonged in time.

Where lake ice reached the lake bottom, spatial variations in snow depth affected rates of permafrost degradation beneath the lake bottom, although $T_{l b}$ values were relatively unaffected. Numerical simulations confirmed that talik 
initiation occurs more promptly and deepening is more rapid for a given $T_{l b}$ when the amplitude of the annual lake-bottom temperature cycle and $F D D / T D D$ decrease. Sensitivity to change in $F D D / T D D$ increased with $F D D / T D D$.

Permafrost may be sustained and talik refreezing may occur at $T_{l b}>0^{\circ} \mathrm{C}$, as talik development rates are moderated by the thermal offset, which shifts the limit of permafrost sustainability towards $(F D D / T D D)<1$ at the lake bottom. Further, the unfrozen water content of fine sediment increases the thermal inertia of permafrost, as an increase in $\theta_{u}$ along the warming permafrost profile does not manifest itself as a talik. Thus, numerical simulations indicated that more heat was required to bring permafrost to $0^{\circ} \mathrm{C}$ and initiate the talik after submergence than to continue talik development once permafrost had been warmed. For example, numerical simulations indicate that talik expansion would continue at a reduced rate when $F D D / T D D$ was 0.51 , but under these conditions talik initiation would not occur for over 50 years after submergence.

This component of the thesis improves understanding of talik development near thermokarst shores. Such knowledge is needed to adequately predict carbon and methane flux from Arctic lowlands affected by thermokarst, as methane release is concentrated near receding lake margins and is most active at the thaw front beneath the lake bottom (Walter et al., 2006, Kessler et al., 2012). It is generally assumed that permafrost will be preserved beneath shallow water that freezes to the bottom in early winter, but these results indicate that taliks may develop beneath water depths as low as $13 \%$ of the maximum ice thickness. Simply assuming that permafrost is preserved beneath shallow water may lead to underestimation of permafrost degradation beneath shallow lakes and ponds. Such an assumption is particularly problematic in places where $F D D / T D D$ may be near $\lambda_{t} / \lambda_{f}$ over extended portions of the lake, for example where lakes are relatively flat-bottomed and mean lake depth is similar to the maximum ice thickness.

Moreover, whereas the general practice when modelling talik development is to 
use a temporal resolution of one year for lake-bottom thermal conditions, this component of the thesis emphasizes the importance of the annual thermal amplitude at the lake bottom to model rates of permafrost degradation where the water column freezes through, and the risk of improper simulation when relying on annual mean temperatures under these conditions. However, the use of mean annual temperatures was effective where seasonal freezing and thawing of the lake bottom was limited in duration and extent. These results can help inform the choice of an appropriate temporal resolution when modelling talik development near thermokarst shorelines.

\subsubsection{Drained basin topography}

The third objective of this thesis was to investigate the topography of drained basins and propose a landform development model adapted to the conditions of OCF. The working hypothesis was that the genesis of depressed margins and raised centres was not dependent on gradients in frost susceptibility nor ice-wedge density along the lake bottom.

Field results indicated that drained basins in a tundra area of OCF exhibited a topographic pattern similar to basins of the Arctic Coastal Plain of Alaska, with mean elevation differences of approximately $1 \mathrm{~m}$ between margins and centres. Contrary to the Arctic Coastal Plain of Alaska, however, this elevation difference was not controlled by differences in ground-ice content between basin centres and margins. There was no relation between segregated excess-ice content in the top two metres of mineral soil and relative elevation of the ground surface. Ice-wedge network density in basin margins was nearly twice that in the centres, suggesting that the distribution of ice wedges may contribute to reducing the overall elevation difference between basin margins and centres rather than contribute to its genesis. These observations support the working hypothesis.

Sediment stratigraphy in the top $2.75 \mathrm{~m}$ of the ground was consistent with 
previous observations from exposures in drained basins of the Alaska Coastal Plain and Tuktoyaktuk Coastlands indicating that greater volumes of sediment are deposited in the basin centre than at the basin margin during lake expansion Britton, 1967, Hopkins and Kidd, 1988, Murton, 1996). This difference in sediment deposition is a product of shore recession, sediment re-suspension by wave action in the near-shore zone, and subsidence of the lake bottom due to talik development. We propose that the resulting pattern of sediment deposition constitutes the main mechanism for the genesis of depressed margins and raised centres in the drained basins of OCF.

This component of the thesis improves understanding of controls on the topography of drained thermokarst lake basins. Research pertaining to conditions in drained basins is timely, as there is increasing interest in their contribution to the greenhouse gas balance of Arctic lowlands (e.g. Sturtevant and Oechel, 2013; Walter-Anthony et al., 2014; Mi et al., 2014). Subtle relief in drained basins creates variable moisture conditions which control methane flux from the basin floor van der Molen et al., 2007). The result and conceptual model presented in Chapter 6 of this thesis clarify controls on the genesis of wet, depressed margins in drained basins.

Drained thermokarst lake basins with depressed margins and raised centres appear to be common in lowlands of the continuous permafrost zone (Fig. 2.6). A previous explanation for this topography focused on the near-shore accumulation of sediment with a low frost susceptibility, such as sand and gravel, and on the preservation of permafrost beneath littoral terraces prior to lake drainage (Jorgenson and Shur, 2007). However basins with similar topographies appear to occur in Arctic lowlands underlain by a range of sediment deposits, including fine marine and glaciolacustrine sediment or coarser alluvial and outwash deposits, and where lakes may or may not have littoral terraces (Fig. 2.6).

This research uses drained basins of OCF to provide field evidence that basins 
in lowlands underlain by fine sediment and where lakes lack littoral shelves may develop a topography similar to the basins of the Alaska Coastal Plain. Moreover it presents a modified landform development model based on lake expansion, sediment re-suspension, and subsidence of the lake bottom, which may be applied to lakes with or without littoral shelves and can combine with the effects of a frost heave gradient where sediment texture allows for such a gradient to develop. Thus this model is applicable to a wide range of sedimentary contexts, which implies that the development of depressed margins in drained basins is likely more widespread than strictly implied by the original model. However this modified model cannot be applied to areas where lakes are not expanding, where the sediment input is too coarse for re-suspension to occur, or where wave base reaches the lake bottom over the entire lake.

\subsection{Directions for further research}

The research presented in this thesis has yielded valuable insights and highlighted questions and problems requiring further investigation. Suggestions for research are organized in four categories: (1) permafrost temperature within the forest-tundra ecotone; (2) permafrost aggradation in drained basins; (3) permafrost degradation beneath shallow water; and (4) the thermokarst lake cycle in OCF.

\subsubsection{Permafrost temperature within the forest-tundra ecotone}

Permafrost temperatures should be monitored to characterize temporal variability within the forest-tundra transition which, much like spatial variability, is necessary to assess the representativeness of data and to design effective sampling programs when evaluating the thermal state of permafrost. In the long-term, interactions between climatic trends, ecological change, and ground temperatures should be examined in areas dominated by low shrubs, tall shrubs, and taiga within the forest 
tundra transition to investigate potential feedback effects and factors increasing vulnerability to environmental change.

\subsubsection{Permafrost aggradation in drained basins}

Landscapes where drained basins are abundant provide an opportunity to examine different stages of permafrost aggradation in drained basins using space-time substitution. The examination of permafrost aggradation in basins of varied ages would help refine understanding of basin topography by characterizing the evolution of depressed margins in relation to the penetration of the freezing front in the

basin-floor sediment. The evolution of remnant ponds should also be investigated to examine their effects on permafrost aggradation and their role in the initiation of secondary thermokarst. The effects of sediment texture and unfrozen water content on rates of permafrost aggradation and heaving of the lake bottom should be examined to better characterize differences between drained basins in environments similar to the Alaska Coastal Plain and to OCF.

\subsubsection{Permafrost degradation beneath shallow water}

Permafrost degradation beneath shallow water in the early stages of thermokarst development is an understudied phase of the thermokarst cycle. There have been several reports of widespread thermokarst initiation resulting from climatic change, but field studies examining conditions surrounding thermokarst initiation are scarce. The conditions allowing small thaw ponds to develop taliks and expand towards becoming thermokarst lakes are poorly defined.

It would be beneficial to investigate permafrost degradation beneath the shallow portions of thermokarst lakes in areas where climate, lake bathymetry, and sediment texture are different from those in OCF. This may help determine whether conditions in OCF are exceptional or only under-represented in the current sample of thermokarst lowlands where talik development has been examined. 


\subsubsection{The thermokarst lake cycle in Old Crow Flats}

The rate of thermokarst lake cycling and the possibility of completing such a cycle in Arctic landscapes has been questioned by Jorgenson and Shur (2007) on the Coastal Plain of Alaska but in other areas, such as the N Seward Peninsula, the rate of thermokarst cycling has been high.

Lantz and Turner (personal communication) propose that the rate of thermokarst lake drainage has accelerated in OCF due to climatic trends over the last 50 years. Such an assessment would benefit from a study of long-term drainage rates in $\mathrm{OCF}$, which could be obtained from the development of a database of peat-bottom ages collected in drained basins in the area. The rate of land area loss to shore recession should also be assessed at the landscape scale to better understand the rate of thermokarst cycling in OCF. 


\section{Bibliography}

Ahlenius, H. (2007), Permafrost Extent in the Northern Hemisphere, Map, 1:10,000,000, UNEP/GRID, Arendal.

Allard, M., and J. N. Kasper (1998), Temperature conditions for ice wedge cracking: field measurements from Salluit, northern Québec, in Proceedings of the Seventh International Conference on Permafrost, Yellowknife, Canada, June 23-27, 1998, Collection Nordicana, pp. 5-12, Centre détudes nordiques, Université Laval, Québec City.

Allenby, R. J. (1989), Clustered, rectangular lakes of the Canadian Old Crow Basin, Tectonophysics, 170(12), 43-56, doi:10.1016/0040-1951(89)90102-9.

Andersland, O. B., and B. Ladanyi (2003), Frozen Ground Engineering, 2nd ed., John Wiley and Sons, Hoboken, NJ.

Apollonio, S., J. W. Cowie, K. Voegtli, R. M. Koerner, P. Cress, R. Wyness, and J. P. Greenhouse (1961), The Devon Island Expedition, Arctic, 14 (4), 252-265, doi:10.14430/arctic3683.

Aré, F. E. (1973), Development of thermokarst lakes in central Yakutia, in Guidebook, Second International Conference on Permafrost, Yakutsk, USSR, 13-28 July, 1973, edited by F. Sanger, p. 29, National Academy of Sciences, Washington DC.

Aré, F. E., and V. T. Balobaev (1979), Characteristics of the reshaping of shorelines of thermokarst lakes of central Yakutia, Draft translation 711, US Army Corps of Engineers, Cold Regions Research and Engineering Laboratory, Hanover, NH.

Arne, I., and O. Anisimov (2008), Climate change and Arctic infrastructure, in Proceedings of the Ninth International Conference on Permafrost, 29 June - 3 July, 2008, Fairbanks, Alaska, vol. 2, edited by D. Kane and K. M. Hinkel, pp. 779-784, Institute of Northern Engineering, University of Alaska Press, Fairbanks, AK.

Arp, C. D., B. M. Jones, F. E. Urban, and G. Grosse (2011), Hydrogeomorphic processes of thermokarst lakes with grounded-ice and floating-ice regimes on the Arctic coastal plain, Alaska, Hydrological Processes, 25(15), 2422-2438, doi:10.1002/hyp.8019.

Balcerak, E. (2011), Thermokarst lakes expand and drain laterally as permafrost degrades, Eos, Transactions American Geophysical Union, 92(45), 408-408, doi:10.1029/2011EO450016. 
Berry, M. (1981), Snow and climate, in Handbook of Snow: Principles, Processes, Management and Use, edited by D. Gray and D. Male, pp. 32-58, Pergamon Press, Toronto.

Beuselinck, L., G. Govers, J. Poesen, G. Degraer, and L. Froyen (1998), Grain-size analysis by laser diffractometry: comparison with the sieve-pipette method, Catena, 32(3-4), 193-208, doi:10.1016/S0341-8162(98)00051-4.

Billings, W. D., and K. M. Peterson (1980), Vegetational change and ice-wedge polygons through the thaw-lake cycle in Arctic Alaska, Arctic and Alpine Research, 12(4), 413-432, doi:10.2307/1550492.

Bintanja, R., and F. M. Selten (2014), Future increases in Arctic precipitation linked to local evaporation and sea-ice retreat, Nature, 509(7501), 479-482, doi:10.1038/nature13259.

Black, R. F., and W. L. Barksdale (1949), Oriented lakes of northern Alaska, The Journal of Geology, 57(2), 105-118.

Blackwell, D., and M. Richards (2004), Geothermal Map of North America, Map, 1:6,500,00, American Association of Petroleum Geologists, Tulsa.

Bockheim, J. G., and K. M. Hinkel (2012), Accumulation of excess ground ice in an age sequence of drained thermokarst lake basins, Arctic Alaska: volume of ground ice increases rapidly in drained thaw lake basins, Permafrost and Periglacial Processes, 23(3), 231-236, doi:10.1002/ppp.1745.

Boon, S., D. O. Burgess, R. M. Koerner, and M. J. Sharp (2010), Forty-seven years of research on the Devon Island Ice Cap, Arctic Canada, Arctic, 63(1), 13-29, doi:10.14430/arctic643.

Bouchard, F., K. W. Turner, L. A. MacDonald, C. Deakin, H. White, N. Farquharson, A. S. Medeiros, B. B. Wolfe, R. I. Hall, R. Pienitz, and T. W. D. Edwards (2013), Vulnerability of shallow subarctic lakes to evaporate and desiccate when snowmelt runoff is low, Geophysical Research Letters, 40(23), 2013GL058,635, doi:10.1002/2013GL058635.

Brewer, M. C. (1958), The thermal regime of an Arctic lake, Transactions, American Geophysical Union, 39(2), 278, doi:10.1029/TR039i002p00278.

Britton, M. E. (1967), Vegetation of the Arctic tundra, in Arctic Biology, edited by H. P. Hansen, pp. 67-130, Oregon State University Press, Corvalis.

Brouchkov, A., M. Fukuda, A. Fedorov, P. Konstantinov, and G. Iwahana (2004), Thermokarst as a short-term permafrost disturbance, central Yakutia, Permafrost and Periglacial Processes, 15(1), 81-87, doi:10.1002/ppp.473. 
Brown, J., J. A. Heginbottom, O. J. Ferrians, and E. S. Melnikov (1997), Circum-Arctic Map of Permafrost and Ground-Ice Conditions, Circum-Pacific Map Series CP-45, 1:10,000,000, Geological Survey of Canada in Cooperation with the Circum-Pacific Council for Energy and Mineral Resources, Washington DC.

Brunet, N. D., G. M. Hickey, and M. M. Humphries (2014a), The evolution of local participation and the mode of knowledge production in Arctic research, Ecology and Society, 19(2), 69, doi:10.5751/ES-06641-190269.

Brunet, N. D., G. M. Hickey, and M. M. Humphries (2014b), Understanding community-researcher partnerships in the natural sciences: a case study from the Arctic, Journal of Rural Studies, 36, 247-261, doi:10.1016/j.jrurstud.2014.09.001.

Burn, C. R. (1988), The development of near-surface ground ice during the Holocene at sites near Mayo, Yukon Territory, Canada, Journal of Quaternary Science, 3(1), 31-38, doi:10.1002/jqs.3390030106.

Burn, C. R. (1990), Frost heave in lake-bottom sediments, Mackenzie Delta, Northwest Territories, in Proceedings of 5th Canadian Permafrost Conference, June 6 -10, 1990, Quebec, Canada, edited by M. Burgess, D. Sego, and D. Harry, Collection Nordicana, No. 54, pp. 926-937, Centre d'études nordiques, Québec City.

Burn, C. R. (1992), Canadian landform examples - 24: Thermokarst lakes, The Canadian Geographer / Le Géographe canadien, 36(1), 81-85.

Burn, C. R. (1994), Permafrost, tectonics, and past and future regional climate change, Yukon and adjacent Northwest Territories, Canadian Journal of Earth Sciences, 31(1), 182-191, doi:10.1139/e94-015.

Burn, C. R. (1997), Cryostratigraphy, paleogeography, and climate change during the early Holocene warm interval, western Arctic coast, Canada, Canadian Journal of Earth Sciences, 34(7), 912-925, doi:10.1139/e17-076.

Burn, C. R. (1998), The response (1958-1997) of permafrost and near-surface ground temperatures to forest fire, Takhini River valley, southern Yukon Territory, Canadian Journal of Earth Sciences, 35(2), 184-199, doi:10.1139/e97-105.

Burn, C. R. (2002), Tundra lakes and permafrost, Richards Island, western Arctic coast, Canada, Canadian Journal of Earth Sciences, 39(8), 1281-1298, doi:10.1139/e02-035.

Burn, C. R. (2003), Lake-bottom thermal regime in thermokarst terrain near Mayo, Yukon Territory, Canada, in Proceedings of the Eighth International Conference on Permafrost, Zurich, Switzerland, July 21-25, 2003, edited by M. Phillips, L. Arenson, and S. Springman, pp. 113-118, Balkema Publishers, Lisse. 
Burn, C. R. (2005), Lake-bottom thermal regimes, western Arctic coast, Canada, Permafrost and Periglacial Processes, 16(4), 355-367, doi:10.1002/ppp.542.

Burn, C. R. (2008), Science in the changing North, Northern Review, (29), 7-20.

Burn, C. R. (2012), Climate, in Herschel Island Qikiqtaryuk: A Natural and Cultural History of Yukon's Arctic Island, edited by C. R. Burn, pp. 48-53, Wildlife Management Advisory Council, Whitehorse.

Burn, C. R. (2013), Thermokarst topography, in Encyclopedia of Quaternary Science, vol. 3, edited by S. Elias, 2nd ed., pp. 574-581, Elsevier, Amsterdam.

Burn, C. R., and S. V. Kokelj (2009), The environment and permafrost of the Mackenzie Delta area, Permafrost and Periglacial Processes, 20 (2), 83-105, doi:10.1002/ppp.655.

Burn, C. R., and A. G. Lewkowicz (1990), Canadian landform examples - 17 retrogressive thaw slumps, Canadian Geographer / Le Géographe canadien, 34(3), 273-276, doi:10.1111/j.1541-0064.1990.tb01092.x.

Burn, C. R., and F. E. Nelson (2006), Comment on "A projection of severe near-surface permafrost degradation during the 21st century" by David M. Lawrence and Andrew G. Slater, Geophysical Research Letters, 33(21), L21,503, doi:10.1029/2006GL027077.

Burn, C. R., and C. A. S. Smith (1988), Observations of the "thermal offset" in near-surface mean annual ground temperatures at several sites near Mayo, Yukon Territory, Canada, Arctic, 41, 99-104, doi:10.1306/74D729D2-2B21-11D7-8648000102C1865D.

Burn, C. R., and M. W. Smith (1990), Development of thermokarst lakes during the Holocene at sites near Mayo, Yukon Territory, Permafrost and Periglacial Processes, 1(2), 161-175, doi:10.1002/ppp.3430010207.

Burt, T. P., and P. J. Williams (1976), Hydraulic conductivity in frozen soils, Earth Surface Processes, 1(4), 349-360, doi:10.1002/esp.3290010404.

Buurman, P., T. Pape, and C. C. Muggler (1997), Laser grain-size determination in soil genetic studies. 1. Practical problems., Soil Science, 162(3), 211-218.

Buurman, P., T. Pape, J. A. Reijneveld, F. d. Jong, and E. v. Gelder (2001), Laser-diffraction and pipette-method grain sizing of Dutch sediments: correlations for fine fractions of marine, fluvial and loess samples, Netherlands Journal of Geosciences, 80(2), 49-57.

Carper, G. L., and R. W. Bachmann (1984), Wind resuspension of sediments in a prairie lake, Canadian Journal of Fisheries and Aquatic Sciences, 41(12), 1763-1767, doi:10.1139/f84-217. 
Carroll, M. L., J. R. G. Townshend, C. M. DiMiceli, T. Loboda, and R. A. Sohlberg (2011), Shrinking lakes of the Arctic: Spatial relationships and trajectory of change, Geophysical Research Letters, 38(20), L20,406, doi:10.1029/2011GL049427.

Carslaw, H. S., and J. C. Jaeger (1995), Conduction of Heat in Solids, 2nd ed., Oxford University Press, Oxford.

Carson, C. E. (1968), Radiocarbon dating of lacustrine strands in Arctic Alaska, Arctic, 21(1), 12-26, doi:10.14430/arctic3242.

Carson, C. E., and K. M. Hussey (1962), The oriented lakes of Arctic Alaska, Journal of Geology, 70, 417-439, doi:10.1086/626834.

Carter, L. D. (1988), Loess and deep thermokarst basins in Arctic Alaska, in Permafrost, Fifth International Conference, August 2-5, 1988, Trondheim, Norway, vol. 1, edited by K. Senneset, pp. 706-711, Tapir Publishers, Trondheim.

CAVM Team (2003), Circumpolar Arctic Vegetation Map, Map, 1:10,000,000, U.S. Fish and Wildlife Service, Anchorage.

Chen, M., J. C. Rowland, C. J. Wilson, G. L. Altmann, and S. P. Brumby (2014), Temporal and spatial pattern of thermokarst lake area changes at Yukon Flats, Alaska, Hydrological Processes, 28(3), 837-852, doi:10.1002/hyp.9642.

Cheng, G. (1983), The mechanism of repeated-segregation for the formation of thick layered ground ice, Cold Regions Science and Technology, 8(1), 57-66, doi:10.1016/0165-232X(83)90017-4.

Chorley, R. J. (1966), The application of statistical methods to geomorphology, in Essays in Geomorphology, edited by D. Dury, pp. 275-387, Heinemann, London.

Church, I. (2009), IPY 2007-2008: an unfolding legacy, Meridian, Fall/winter, 16-21.

Church, M. (1996), Space, time and the mountain: how do we order what we see?, in The Scientific Nature of Geomorphology: Proceedings of the 27th Binghamton Symposium in Geomorphology, 27-29 September, 1996, vol. 27, pp. 147-170, Wiley-Blackwell, Binghampton.

Church, M. (2013), Refocusing geomorphology: field work in four acts, Geomorphology, 200, 184-192, doi:10.1016/j.geomorph.2013.01.014.

Clarke, G. K. C. (2014), A short and somewhat personal history of Yukon glacier studies in the twentieth century, Arctic, 67(5), 1-21, doi:10.14430/arctic4355.

Côté, M. M., and C. R. Burn (2002), The oriented lakes of Tuktoyaktuk Peninsula, western Arctic Coast, Canada: a GIS-based analysis, Permafrost and Periglacial Processes, 13(1), 61-70, doi:10.1002/ppp.407. 
Darrow, M. M. (2011), Thermal modeling of roadway embankments over permafrost, Cold Regions Science and Technology, 65(3), 474-487, doi:10.1016/j.coldregions.2010.11.001.

Davidson-Arnott, R. G. D. (2010), Introduction to Coastal Processes and Geomorphology, Cambridge University Press, New York.

Dean, W. E. J. (1974), Determination of carbonate and organic matter in calcareous sediments and sedimentary rocks by loss on ignition: comparison with other methods, Journal of Sedimentary Research, 44 (1), 242-248, doi:10.1306/74D729D2-2B21-11D7-8648000102C1865D.

Duk-Rodkin, A., R. W. Barendregt, D. G. Froese, F. Weber, R. Enkin, I. Rod Smith, G. D. Zazula, P. Waters, and R. Klassen (2004), Timing and extent of Plio-Pleistocene glaciations in north-western Canada and east-central Alaska, in Developments in Quaternary Sciences, Quaternary Glaciations - Extent and Chronology Part II: North America, vol. 2B, edited by J. Ehlers and P.L. Gibbard, pp. 313-345, Elsevier, Amsterdam.

Dyke, L. D., and W. E. Sladen (2010), Permafrost and peatland evolution in the northern Hudson Bay Lowland, Manitoba, Arctic, 63(4), 429-441, doi:10.14430/arctic3332.

EBA Engineering Consultants Ltd (1982), Old Crow Groundwater Supply: A Geotechnical, Hydrological and Thermal Study, Report to Yukon Territorial Government, EBA Engineering Consultants Ltd, Whitehorse.

Eisner, W. R., and K. M. Peterson (1998), Pollen, fungi and algae as age indicators of drained lake basins near Barrow, Alaska, in Proceedings of the Seventh International Conference on Permafrost, Yellowknife, Canada, June 23-27 1998., Collection Nordicana, vol. 57, edited by A. G. Lewkowicz and M. Allard, pp. 245-250, Centre d'études nordiques, Université Laval, Quebec city.

Eisner, W. R., C. J. Cuomo, K. M. Hinkel, B. M. Jones, and S. Ronald H. Brower (2009), Advancing landscape change research through the incorporation of Iñupiaq knowledge, Arctic, 62(4), 429-442, doi:10.14430/arctic174.

Eleveld, M. A. (2012), Wind-induced resuspension in a shallow lake from Medium Resolution Imaging Spectrometer (MERIS) full-resolution reflectances, Water Resources Research, 48(4), W04,508, doi:10.1029/2011WR011121.

Ensom, T. P., C. R. Burn, and S. V. Kokelj (2012), Lake- and channel-bottom temperatures in the Mackenzie Delta, Northwest Territories, Canadian Journal of Earth Sciences, 49(8), 963-978, doi:10.1139/e2012-001.

Fedorov, A., and P. Konstantinov (2003), Observations of surface dynamics with thermokarst initiation, Yukechi site, Central Yakutia, in Proceedings of the Eighth 
International Conference on Permafrost, Zurich, Switzerland, July 21-25, 2003, edited by M. Phillips, S. Springman, and L. Arenson, pp. 239-243, Balkema Publishers, Lisse.

French, H., and Y. Shur (2010), The principles of cryostratigraphy, Earth-Science Reviews, 101 (34), 190-206, doi:10.1016/j.earscirev.2010.04.002.

French, H. M. (2007), The Periglacial Environment, 3rd ed., Wiley-Blackwell, Chichester.

Frohn, R. C., K. M. Hinkel, and W. R. Eisner (2005), Satellite remote sensing classification of thaw lakes and drained thaw lake basins on the North Slope of Alaska, Remote Sensing of Environment, 97(1), 116-126, doi:10.1016/j.rse.2005.04.022.

Gabrielse, H. (1967), Tectonic evolution of the northern Canadian Cordillera, Canadian Journal of Earth Sciences, 4 (2), 271-298, doi:10.1139/e67-013.

GEO-SLOPE International Ltd (2010), Thermal modeling with TEMP/W 200\%: an engineering methodology, Fourth Edition, GEO-SLOPE International, Ltd., Calgary.

Goodrich, L. E. (1982), The influence of snow cover on the ground thermal regime, Canadian Geotechnical Journal, 19(4), 421-432, doi:10.1139/t82-047.

Graham, J., and E. Fortier (2005), From Opportunity to Action: A Progress Report on Canada's Renewal of Northern Research, Report submitted by the institute on governance to the planning committee for the dialogue on northern research, NSERC, Ottawa.

Gray, D. R., and B. T. Alt (2001), Resource Description and Analysis of Vuntut National Park of Canada, Parks Canada, Whitehorse.

Grosse, G., B. M. Jones, and C. D. Arp (2013), Thermokarst lakes, drainage, and drained basins, in Treatise on Geomorphology, Glacial and Periglacial Geomorphology, vol. 8, edited by J. F. Shroder, pp. 325-353, Academic Press, San Diego.

Grosswald, M. G., T. J. Hughes, and N. P. Lasca (1999), Oriented lake-and-ridge assemblages of the Arctic coastal plains: glacial landforms modified by thermokarst and solifluction, Polar Record, 35(194), 215-230, doi:10.1017/S0032247400015503.

Harden, C. P. (2013), Geomorphology in context: dispatches from the field, Geomorphology, 200, 34-41, doi:10.1016/j.geomorph.2013.03.025.

Hare, F. K., and J. C. Ritchie (1972), The Boreal bioclimates, Geographical Review, 62(3), 333, doi:10.2307/213287. 
Harington, C. R. (1977), Pleistocene Mammals of the Yukon Territory, Ph.D.

Thesis, University of Alberta, Edmonton.

Harry, D. G., and H. M. French (1983), The orientation and evolution of thaw lakes, southwest Banks Island, Canadian Arctic, in Proceedings of the Fourth International Conference on Permafrost, Fairbanks, USA, July 17-22, 1983, edited by R. D. Miller, pp. 456-441, National Academy of Sciences, Washington D.C.

Harvey, B. J., L. C. Shaffrey, and T. J. Woollings (2014), Equator-to-pole temperature differences and the extra-tropical storm track responses of the CMIP5 climate models, Climate Dynamics, 43(5-6), 1171-1182, doi:10.1007/s00382-013-1883-9.

Hedstrom, N. R., and J. W. Pomeroy (1998), Measurements and modelling of snow interception in the boreal forest, Hydrological Processes, 12(1011), 1611-1625, doi:10.1002/(SICI)1099-1085(199808/09)12:10/11〈1611::AID-HYP684〉3.0.CO;2-4.

Heiri, O., A. F. Lotter, and G. Lemcke (2001), Loss on ignition as a method for estimating organic and carbonate content in sediments: reproducibility and comparability of results, Journal of Paleolimnology, 25(1), 101-110, doi:10.1023/A:1008119611481.

Hinkel, K. (2006), Comment on "Formation of oriented thaw lakes by thaw slumping" by Jon D. Pelletier, Journal of Geophysical Research: Earth Surface, 111 (F1), F01,021, doi:10.1029/2005JF000377.

Hinkel, K. M., R. C. Frohn, F. E. Nelson, W. R. Eisner, and R. A. Beck (2005), Morphometric and spatial analysis of thaw lakes and drained thaw lake basins in the western Arctic Coastal Plain, Alaska, Permafrost and Periglacial Processes, 16(4), 327-341, doi:10.1002/ppp.532.

Hinkel, K. M., B. M. Jones, W. R. Eisner, C. J. Cuomo, R. A. Beck, and R. Frohn (2007), Methods to assess natural and anthropogenic thaw lake drainage on the western Arctic coastal plain of northern Alaska, Journal of Geophysical Research: Earth Surface, 112(F2), F02S16, doi:10.1029/2006JF000584.

Hinkel, K. M., Y. Sheng, J. D. Lenters, E. A. Lyons, R. A. Beck, W. R. Eisner, and J. Wang (2012), Thermokarst lakes on the Arctic Coastal Plain of Alaska: geomorphic controls on bathymetry, Permafrost and Periglacial Processes, 23(3), 218-230, doi:10.1002/ppp.1744.

Hopkins, D. M., and J. G. Kidd (1988), Thaw lake sediments and sedimentary environments, in Permafrost, Fifth International Conference, August 2-5, 1988, Trondheim, Norway, edited by K. Senneset, pp. 790-795, Tapir Publishers, Trondheim. 
Hughes, O. L., J. Pilon, J. J. Veillette, S. C. Zoltai, and W. W. Pettapiece (1973), Three surficial geology and geomorphology maps of Trial River, Bell River, Old Crow map-areas, Mackenzie Valley and northern Yukon Territory, Open File 167 167, Geological Survey of Canada, Ottawa.

Hussey, K. M., and R. W. Michelson (1966), Tundra relief features near Point Barrow, Alaska, Arctic, 19(2), 162-184, doi:10.14430/arctic3423.

Hwang, C., and M. W. Smith (1973), Thermal disturbance due to channel shifting, Mackenzie Delta, NWT, Canada, in Proceedings of the Second International Conference on Permafrost, Yakutsk, USSR, 13-28 July, 1973, North American Contribution, vol. 2, edited by F. Sanger and P. Hyde, pp. 51-60, National Academy of Sciences, Washington DC.

Iijima, Y., A. N. Fedorov, H. Park, K. Suzuki, H. Yabuki, T. C. Maximov, and T. Ohata (2010), Abrupt increases in soil temperatures following increased precipitation in a permafrost region, central Lena River basin, Russia, Permafrost and Periglacial Processes, 21 (1), 30-41, doi:10.1002/ppp.662.

Johansen, O. (1977), Thermal Conductivity of Soils, Draft translation 637, CRREL, Hanover, NH.

Jones, B. M., G. Grosse, C. D. Arp, M. C. Jones, K. M. Walter Anthony, and V. E. Romanovsky (2011), Modern thermokarst lake dynamics in the continuous permafrost zone, northern Seward Peninsula, Alaska, Journal of Geophysical Research: Biogeosciences, 116(G2), G00M03, doi:10.1029/2011JG001666.

Jorgenson, M. T. (2013), Thermokarst terrains, in Treatise on Geomorphology, edited by J. F. Shroder, pp. 313-324, Academic Press, San Diego.

Jorgenson, M. T., and Y. Shur (2007), Evolution of lakes and basins in northern Alaska and discussion of the thaw lake cycle, Journal of Geophysical Research, 112(F2), doi:10.1029/2006JF000531.

Jorgenson, M. T., E. R. Pullman, and Y. L. Shur (2003), Geomorphology of the Northeast Planning Area, National Petroleum Reserve-Alaska, 2002, Report to ConocoPhilips Alaska inc. and Anadarko Petroleum Corporation, Fairbanks, AK.

Jorgenson, M. T., Y. L. Shur, and E. R. Pullman (2006), Abrupt increase in permafrost degradation in Arctic Alaska, Geophysical Research Letters, 33 (2), doi:10.1029/2005GL024960.

Kanevskiy, M., Y. Shur, M. Jorgenson, C.-L. Ping, G. Michaelson, D. Fortier, E. Stephani, M. Dillon, and V. Tumskoy (2013), Ground ice in the upper permafrost of the Beaufort Sea coast of Alaska, Cold Regions Science and Technology, 85, 56-70, doi:10.1016/j.coldregions.2012.08.002. 
Kanigan, J. C. N., C. R. Burn, and S. V. Kokelj (2008), Permafrost response to climate warming south of treeline, Mackenzie Delta, Northwest Territories, Canada, in Proceedings of the 9th International Conference on Permafrost, Fairbanks, Alaska, 29 June-3 July 2008, vol. 1, edited by D. Kane and K. M. Hinkel, pp. 901-906, Institute for Northern Engineering, University of Alaska Fairbanks, Fairbanks.

Kanigan, J. C. N., C. R. Burn, and S. V. Kokelj (2009), Ground temperatures in permafrost south of treeline, Mackenzie Delta, Northwest Territories, Permafrost and Periglacial Processes, 20(2), 127-139, doi:10.1002/ppp.643.

Karlsson, J., R. Giesler, J. Persson, and E. Lundin (2013), High emission of carbon dioxide and methane during ice thaw in high latitude lakes, Geophysical Research Letters, 40(6), 1123-1127, doi:10.1002/grl.50152.

Karunaratne, K. C. (2011), A Field Examination of Climate-Permafrost Relations in Continuous and Discontinuous Permafrost of the Slave Geological Province, Ph.D. Thesis, Carleton University, Ottawa.

Karunaratne, K. C., and C. R. Burn (2003), Freezing n-factors in discontinuous permafrost terrain, Takhini River, Yukon Territory, Canada, in Proceedings of the Eighth International Conference on Permafrost, Zurich, Switzerland, July 21-25, 2003, edited by M. Phillips, S. Springman, and L. Arenson, pp. 519-524, Balkema Publishers, Lisse.

Kennedy, K., and D. G. Froese (2008), Aggregate resource exploration using a process-depositional model of meltwater channel development in the Eagle Plains area, northern Yukon, in Yukon Exploration and Geology 200\%, edited by D. Emond, L. Blackburn, R. Hill, and L. Weston, pp. 169-178, Yukon Geological Survey, Whitehorse.

Kershaw, G. P., and J. McCulloch (2007), Midwinter snowpack variation across the Arctic treeline, Churchill, Manitoba, Canada, Arctic, Antarctic, and Alpine Research, 39(1), 9-15, doi:10.1657/1523-0430(2007)39[9:MSVATA]2.0.CO;2.

Kessler, M. A., L. J. Plug, and K. M. Walter Anthony (2012), Simulating the decadal- to millennial-scale dynamics of morphology and sequestered carbon mobilization of two thermokarst lakes in NW Alaska, Journal of Geophysical Research: Biogeosciences, 117(G2), G00M06, doi:10.1029/2011JG001796.

Klein, E. S., Z. Yu, and R. K. Booth (2013), Recent increase in peatland carbon accumulation in a thermokarst lake basin in southwestern Alaska, Palaeogeography, Palaeoclimatology, Palaeoecology, 392, 186-195, doi:10.1016/j.palaeo.2013.09.009.

Kokelj, S. V., and C. R. Burn (2003), Ground ice and soluble cations in near-surface permafrost, Inuvik, Northwest Territories, Canada, Permafrost and Periglacial Processes, 14 (3), 275-289, doi:10.1002/ppp.458. 
Kokelj, S. V., and M. T. Jorgenson (2013), Advances in thermokarst research: recent advances in research investigating thermokarst processes, Permafrost and Periglacial Processes, 24(2), 108-119, doi:10.1002/ppp.1779.

Kokelj, S. V., T. C. Lantz, J. Kanigan, S. L. Smith, and R. Coutts (2009), Origin and polycyclic behaviour of tundra thaw slumps, Mackenzie Delta region, Northwest Territories, Canada, Permafrost and Periglacial Processes, 20(2), 173-184, doi:10.1002/ppp.642.

Kokelj, S. V., T. C. Lantz, S. Solomon, M. F. Pisaric, D. Keith, P. Morse, J. R. Thienpont, J. P. Smol, and D. Esagok (2012), Using multiple sources of knowledge to investigate northern environmental change: regional ecological impacts of a storm surge in the outer Mackenzie Delta, NWT, Arctic, 65, 257-272, doi:10.14430/arctic4214.

Kokelj, S. V., T. C. Lantz, S. A. Wolfe, J. C. Kanigan, P. D. Morse, R. Coutts, N. Molina-Giraldo, and C. R. Burn (2014), Distribution and activity of ice wedges across the forest-tundra transition, western Arctic Canada, Journal of Geophysical Research: Earth Surface, 119(9), 2014JF003,085, doi:10.1002/2014JF003085.

Konrad, J. (1999), Frost susceptibility related to soil index properties, Canadian Geotechnical Journal, 36(3), 403-417, doi:10.1139/t99-008.

Kudryavtsev, V. (Ed.) (1981), The Permafrost Study (in Russian), Moscow University Press, Moscow.

Kuhn, T. S. (1962), The Structure of Scientific Revolutions, University of Chicago Press, Chicago.

Labrecque, S., D. Lacelle, C. R. Duguay, B. Lauriol, and J. Hawkings (2009), Contemporary (1951-2001) evolution of lakes in the Old Crow Basin, Northern Yukon, Canada: remote sensing, numerical modeling, and stable isotope analysis, Arctic, 62, 225-238, doi:10.14430/arctic134.

Lachenbruch, A. H. (1962), Mechanics of thermal contraction cracks and ice-wedge polygons in permafrost, Geological Society of America Special Papers, 70, 1-66, doi:10.1130/SPE70-p1.

Lachenbruch, A. H. (1963), Contraction theory of ice-wedge polygons: A qualitative discussion, in proceedings, Permafrost International Conference, lafayette, USA, 11-15 November 1963., pp. 63-71, National Academy of Sciences, Washington DC.

Lafleur, P. M., A. V. Renzetti, and R. Bello (1993), Seasonal changes in the radiation balance of subarctic forest and tundra, Arctic and Alpine Research, 25(1), 32, doi:10.2307/1551477. 
Lantuit, H., P. P. Overduin, and S. Wetterich (2013), Recent progress regarding permafrost coasts, Permafrost and Periglacial Processes, 24(2), 120-130, doi:10.1002/ppp.1777.

Lantz, T. C., and S. V. Kokelj (2008), Increasing rates of retrogressive thaw slump activity in the Mackenzie Delta region, N.W.T., Canada, Geophysical Research Letters, 35 (6), L06,502, doi:10.1029/2007GL032433.

Lantz, T. C., S. E. Gergel, and S. V. Kokelj (2010), Spatial heterogeneity in the shrub tundra ecotone in the Mackenzie Delta region, Northwest Territories: implications for Arctic environmental change, Ecosystems, 13(2), 194-204, doi:10.1007/s10021-009-9310-0.

Lantz, T. C., P. Marsh, and S. V. Kokelj (2013), Recent shrub proliferation in the Mackenzie Delta uplands and microclimatic implications, Ecosystems, 16(1), 47-59, doi:10.1007/s10021-012-9595-2.

Lauriol, B., Y. Cabana, J. Cinq-Mars, M.-A. Geurts, and F. W. Grimm (2002), Cliff-top eolian deposits and associated molluscan assemblages as indicators of Late Pleistocene and Holocene environments in Beringia, Quaternary International, 87(1), 59-79, doi:10.1016/S1040-6182(01)00062-3.

Lauriol, B., D. Lacelle, S. Labrecque, C. R. Duguay, and A. Telka (2009), Holocene evolution of lakes in the Bluefish Basin, northern Yukon, Canada, Arctic, 62 (2), 212-224, doi:10.14430/arctic133.

Lawrence, J. R. (1973), Old Crow Basin, in Future Petroleum Provinces of Canada, Their Geology and Potential, edited by R. McCrossan, CSPG, Memoir 1, pp. 307-314, Canadian Society of Petroleum Geologists, Calgary.

Lawson, D. E. (1983), Ground ice in perennially frozen sediments, northern Alaska, in Proceedings of the Fourth International Conference on Permafrost, Fairbanks, USA, July 17-22 1983, edited by R. D. Miller, pp. 695-700, National Academy of Sciences, Washington DC.

Lewellen, R. I. (1970), Permafrost erosion along the Beaufort Sea coast, Technical report 1962-1968, Arctic Institute of North America, Washington D.C.

Lewkowicz, A. G. (1990), Morphology, frequency and magnitude of active-layer detachment slides, Fosheim Peninsula, Ellesmere Island, NWT, in Proceedings of the Fifth Canadian Permafrost Conference, Quebec, Canada, 6-8 June, 1990, Collection Nordicana No. 54, pp. 111-118, Centre d'études nordiques, Université Laval, Québec City.

Lichti-Federovich, S. (1973), Palynology of six sections of Late Quaternary sediments from the Old Crow River, Yukon Territory, Canadian Journal of Botany, 51(3), 553-564, doi:10.1139/b73-066. 
Lin, Z., F. Niu, Z. Xu, J. Xu, and P. Wang (2010), Thermal regime of a thermokarst lake and its influence on permafrost, Beiluhe Basin, Qinghai-Tibet Plateau, Permafrost and Periglacial Processes, 21 (4), 315-324, doi:10.1002/ppp.692.

Ling, F., and T. Zhang (2004), Modeling study of talik freeze-up and permafrost response under drained thaw lakes on the Alaskan Arctic Coastal Plain, Journal of Geophysical Research: Atmospheres, 109(D1), D01,111, doi:10.1029/2003JD003886.

Liu, L., K. Schaefer, A. Gusmeroli, G. Grosse, B. M. Jones, T. Zhang, A. D. Parsekian, and H. A. Zebker (2014), Seasonal thaw settlement at drained thermokarst lake basins, Arctic Alaska, The Cryosphere, 8(3), 815-826, doi:10.5194/tc-8-815-2014.

Livingstone, D. A. (1954), On the orientation of lake basins, American Journal of Science, 252(9), 547-554, doi:10.2475/ajs.252.9.547.

Mackay, J. R. (1962), Pingos of the Pleistocene Mackenzie delta area, Geographical Bulletin, 18(2), 1-63.

Mackay, J. R. (1963), The Mackenzie Delta area, NWT, Geographical Branch Memoir 8, Department of Mines and Technical Surveys, Ottawa.

Mackay, J. R. (1971), The origin of massive icy beds in permafrost, western Arctic coast, Canada, Canadian Journal of Earth Sciences, 8(4), 397-422, doi:10.1139/e71-043.

Mackay, J. R. (1972), The world of underground ice, Annals of the Association of American Geographers, 62(1), 1-22, doi:10.1111/j.1467-8306.1972.tb00839.x.

Mackay, J. R. (1973), The growth of pingos, western Arctic coast, Canada, Canadian Journal of Earth Sciences, 10(6), 979-1004, doi:10.1139/e73-086.

Mackay, J. R. (1974), Ice-wedge cracks, Garry Island, Northwest Territories, Canadian Journal of Earth Sciences, 11(10), 1366-1383, doi:10.1139/e74-133.

Mackay, J. R. (1981), An experiment in lake drainage, Richards Island, Northwest Territories: a progress report, Current Research, Part A, Geological Survey of Canada, Paper, 81, 63-68.

Mackay, J. R. (1983), Downward water movement into frozen ground, western Arctic coast, Canada, Canadian Journal of Earth Sciences, 20(1), 120-134, doi:10.1139/e83-012.

Mackay, J. R. (1988), Catastrophic lake drainage, Tuktoyaktuk peninsula area, District of Mackenzie, Current Research, Part D, Geological Survey of Canada, Paper, 88, 83-90. 
Mackay, J. R. (1992), Lake stability in an ice-rich permafrost environment: examples from the western Arctic coast, in Aquatic Ecosystems in Semi-arid Regions: Implications for Resource Management, August 27-30, 1990, Saskatoon, Canada, edited by R. Robarts and M. Bothwell, no. 7 in N.H.R.I. Symposium Series, pp. 1-25, National Hydrology Research Institute, Environment Canada, Saskatoon.

Mackay, J. R. (1997), A full-scale field experiment (1978-1995) on the growth of permafrost by means of lake drainage, western Arctic coast: a discussion of the method and some results, Canadian Journal of Earth Sciences, 34 (1), 17-33, doi:10.1139/e17-002.

Mackay, J. R. (2000), Thermally induced movements in ice-wedge polygons, western Arctic coast: a long-term study, Géographie Physique et Quaternaire, 54 (1), 41, doi:10.7202/004846ar.

Mackay, J. R., and C. R. Burn (2002), The first 20 years (1978-1979 to 1998-1999) of ice-wedge growth at the Illisarvik experimental drained lake site, western Arctic coast, Canada, Canadian Journal of Earth Sciences, 39(1), 95-111, doi:10.1139/e01-048.

Mackay, J. R., and D. K. MacKay (1974), Snow cover and ground temperatures, Garry Island, NWT, Arctic, 27, 287-296, doi:10.14430/arctic2885.

Macrae, M., L. Brown, C. Duguay, J. Parrott, and R. Petrone (2014), Observed and projected climate change in the Churchill region of the Hudson Bay Lowlands and implications for pond sustainability, Arctic, Antarctic, and Alpine Research, 46(1), 272-285, doi:10.1657/1938-4246-46.1.272.

Maloney, E. D., S. J. Camargo, E. Chang, B. Colle, R. Fu, K. L. Geil, Q. Hu, X. Jiang, N. Johnson, K. B. Karnauskas, J. Kinter, B. Kirtman, S. Kumar, B. Langenbrunner, K. Lombardo, L. N. Long, A. Mariotti, J. E. Meyerson, K. C. Mo, J. D. Neelin, Z. Pan, R. Seager, Y. Serra, A. Seth, J. Sheffield, J. Stroeve, J. Thibeault, S.-P. Xie, C. Wang, B. Wyman, and M. Zhao (2013), North American climate in CMIP5 experiments: Part III: assessment of twenty-first-century projections, Journal of Climate, 27(6), 2230-2270, doi:10.1175/JCLI-D-13-00273.1.

Mangum, B. (1995), Reproducibility of the temperature of the ice point in routine measurements, Technical Note TN1411, Thermometry group, National Institute of Standards and Technology, Gaithersburg.

Marsh, P., M. Russell, S. Pohl, H. Haywood, and C. Onclin (2009), Changes in thaw lake drainage in the western Canadian Arctic from 1950 to 2000, Hydrological Processes, 23(1), 145-158, doi:10.1002/hyp.7179.

Matell, N., R. S. Anderson, I. Overeem, C. Wobus, F. E. Urban, and G. D. Clow (2013), Modeling the subsurface thermal impact of Arctic thaw lakes in a warming climate, Computers and Geosciences, 53, 69-79, doi:10.1016/j.cageo.2011.08.028. 
Matthews, J. V., C. R. Harington, O. L. Hughes, R. E. Morlan, N. W. Rutter, C. E. Schweger, and C. Tarnocai (1987), Schaeffer Mountain Lookout and Old Crow Basin stratigraphy/paleontology, in Guidebook to Quaternary Research in Yukon. XII INQUA Congress, Ottawa, Canada, 31 July-9 August, 1987, edited by C. Smith and S. Morison, pp. 75-83, National Research Council of Canada, Ottawa, Canada.

Matthews, J. V. J., C. E. Schweger, and J. A. Janssens (1990), The last (Koy-Yukon) interglaciation in the northern Yukon: evidence from Unit 4 at Chijees Bluff, Bluefish Basin, Géographie Physique et Quaternaire, 44(3), 341-362, doi:10.7202/032835ar.

Mi, Y., J. van Huissteden, and A. J. Dolman (2014), Modelled present and future thaw lake area expansion/contraction trends throughout the continuous permafrost zone, The Cryosphere Discussions, 8(4), 3603-3627, doi:10.1038/NCLIMATE1101.

Miller, R. D. (1972), Freezing and heaving of saturated and unsaturates soils, in Maintenance Systems: 7 Reports Prepared for the 51st Annual Meeting of the Highway Research Board, Washington DC, USA, 17-21 January, 1972, Highway research bulletin record 391, pp. 1-11, National Research Council, Washington DC.

Morgenstern, A., G. Grosse, F. Gnther, I. Fedorova, and L. Schirrmeister (2011), Spatial analyses of thermokarst lakes and basins in Yedoma landscapes of the Lena Delta, The Cryosphere, 5(4), 849-867, doi:10.5194/tc-5-849-2011.

Morlan, R. E. (2003), Current perspectives on the Pleistocene archaeology of eastern Beringia, Quaternary Research, 60(1), 123-132, doi:10.1016/S0033-5894(03)00070-X.

Morrell, G., and J. R. Dietrich (1993), Evaluation of the hydrocarbon prospectivity of the Old Crow Flats area of the northern Yukon, Bulletin of Canadian Petroleum Geology, 41(1), 32-45.

Morse, P., C. Burn, and S. Kokelj (2012), Influence of snow on near-surface ground temperatures in upland and alluvial environments of the outer Mackenzie Delta, Northwest Territories, Canadian Journal of Earth Sciences, 49(8), 895-913, doi:10.1139/e2012-012.

Morse, P. D., and C. R. Burn (2013), Field observations of syngenetic ice wedge polygons, outer Mackenzie Delta, western Arctic coast, Canada, Journal of Geophysical Research: Earth Surface, 118(3), 1320-1332, doi:10.1002/jgrf.20086.

Murray, M. R. (2002), Is laser particle size determination possible for carbonate-rich lake sediments?, Journal of Paleolimnology, 27(2), 173-183, doi:10.1023/A:1014281412035. 
Murton, J. B. (1993), Thermokarst Sedimentology of the Tuktoyaktuk Coastlands, Northwest Territories, Ph.D. Thesis, University of Ottawa, Ottawa.

Murton, J. B. (1996), Thermokarst-lake-basin sediments, Tuktoyaktuk Coastlands, western arctic Canada, Sedimentology, 43(4), 737-760, doi:10.1111/j.1365-3091.1996.tb02023.x.

Murton, J. B. (2001), Thermokarst sediments and sedimentary structures, Tuktoyaktuk Coastlands, western Arctic Canada, Global and Planetary Change, 28(14), 175-192, doi:10.1016/S0921-8181(00)00072-2.

Necsoiu, M., C. L. Dinwiddie, G. R. Walter, A. Larsen, and S. A. Stothoff (2013), Multi-temporal image analysis of historical aerial photographs and recent satellite imagery reveals evolution of water body surface area and polygonal terrain morphology in Kobuk Valley National Park, Alaska, Environmental Research Letters, 8(2), 025,007, doi:10.1088/1748-9326/8/2/025007.

Nelson, F. E., O. A. Anisimov, and N. I. Shiklomanov (2001), Subsidence risk from thawing permafrost, Nature, 410(6831), 889-890, doi:10.1038/35073746.

Neville, L. A., R. T. Patterson, P. Gammon, and A. L. Macumber (2014), Relationship between ecological indicators (Arcellacea), total mercury concentrations and grain size in lakes within the Athabasca oil sands region, Alberta, Environmental Earth Sciences, 72(2), 577-588, doi:10.1007/s12665-013-2979-6.

Nicholson, F., H. Granberg, and F. Sanger (1973), Permafrost and snowcover relationships near Sschefferville, in Second International Conference on Permafrost, Yakutsk, USSR, 13-28 July, 1973, edited by F. Sanger and P. Hyde, pp. 151-158, National Academy of Sciences, Washington DC.

Oke, T. R. (1982), The energetic basis of the urban heat island, Quarterly Journal of the Royal Meteorological Society, 108(455), 1-24, doi:10.1002/qj.49710845502.

O’Neill, H. B., and C. R. Burn (2012), Physical and temporal factors controlling the development of near-surface ground ice at Illisarvik, western Arctic coast, Canada, Canadian Journal of Earth Sciences, 49(9), 1096-1110, doi:10.1139/e2012-043.

O'Neill, K., and R. D. Miller (1985), Exploration of a rigid ice model of frost heave, Water Resources Research, 21(3), 281-296, doi:10.1029/WR021i003p00281.

Outcalt, S. I., and K. M. Hinkel (1996), The response of near-surface permafrost to seasonal regime transitions in tundra terrain, Arctic and Alpine Research, 28(3), 274-283, doi:10.2307/1552106.

Ovenden, L. (1985), Hydroseral Histories of the Old Crow Peatlands, Northern Yukon, Ph.D. Thesis, University of Toronto, Toronto. 
Ovenden, L., and G. R. Brassard (1989), Wetland vegetation near Old Crow, northern Yukon, Canadian Journal of Botany, 67(4), 954-960, doi:10.1139/b89-127.

Palmer, M. J., C. R. Burn, S. V. Kokelj, and M. Allard (2012), Factors influencing permafrost temperatures across tree line in the uplands east of the Mackenzie Delta, Canadian Journal of Earth Sciences, 49(8), 877-894, doi:10.1139/e2012-002.

Payette, S., M. J. Fortin, and I. Gamache (2001), The subarctic forest-tundra: the structure of a biome in a changing climate, BioScience, 51(9), 709-718, doi:10.1641/0006-3568(2001)051[0709:TSFTTS]2.0.CO;2.

Pearce, G. W., J. A. Westgate, and S. Robertson (1982), Magnetic reversal history of Pleistocene sediments at Old Crow, northwestern Yukon Territory, Canadian Journal of Earth Sciences, 19(5), 919-929, doi:10.1139/e82-077.

Pearce, T. D., J. D. Ford, G. J. Laidler, B. Smit, F. Duerden, M. Allarut, M. Andrachuk, S. Baryluk, A. Dialla, P. Elee, A. Goose, T. Ikummaq, E. Joamie, F. Kataoyak, E. Loring, S. Meakin, S. Nickels, K. Shappa, J. Shirley, and J. Wandel (2009), Community collaboration and climate change research in the Canadian Arctic, Polar Research, 28(1), 10-27, doi:10.1111/j.1751-8369.2008.00094.x.

Pelletier, J. D. (2005), Formation of oriented thaw lakes by thaw slumping, Journal of Geophysical Research: Earth Surface, 110(F2), F02,018, doi:10.1029/2004JF000158.

Phillipson, J., P. Lowe, A. Proctor, and E. Ruto (2012), Stakeholder engagement and knowledge exchange in environmental research, Journal of Environmental Management, 95(1), 56-65, doi:10.1016/j.jenvman.2011.10.005.

Pissart, A. (2002), Palsas, lithalsas and remnants of these periglacial mounds. A progress report, Progress in Physical Geography, 26 (4), 605-621, doi:10.1191/0309133302pp354ra.

Plug, L. J., and J. J. West (2009), Thaw lake expansion in a two-dimensional coupled model of heat transfer, thaw subsidence, and mass movement, Journal of Geophysical Research: Earth Surface, 114(F1), F01,002, doi:10.1029/2006JF000740.

Pollard, W. H., and H. M. French (1980), A first approximation of the volume of ground ice, Richards Island, Pleistocene Mackenzie delta, Northwest Territories, Canada, Canadian Geotechnical Journal, 17(4), 509-516, doi:10.1139/t80-059.

Pomeroy, J. W., P. Marsh, H. G. Jones, and T. D. Davies (1995), Spatial distribution of snow chemical load at the tundra-taiga transition, in 
Biogeochemistry of seasonally snow-covered catchments, edited by K. Tonnessen, M. Williams, and M. Tranter, Volume 228 of the International Association of Hydrological Sciences, pp. 191-203, International Association of Hydrological Sciences, Wallingford.

Pomeroy, J. W., D. M. Gray, N. R. Hedstrom, and J. R. Janowicz (2002), Prediction of seasonal snow accumulation in cold climate forests, Hydrological Processes, 16 (18), 3543-3558, doi:10.1002/hyp.1228.

Porter, T. J., and M. F. J. Pisaric (2011), Temperature-growth divergence in white spruce forests of Old Crow Flats, Yukon Territory, and adjacent regions of northwestern North America, Global Change Biology, 17(11), 3418-3430, doi:10.1111/j.1365-2486.2011.02507.x.

Powell, R. C. (2007), "The rigours of an Arctic experiment": the precarious authority of field practices in the Canadian High Arctic, 1958-1970, Environment and Planning A, 39(8), 1794 - 1811, doi:10.1068/a38294.

Price, W. A. (1968), Oriented lakes, in Geomorphology, edited by C. Finkl, Encyclopedia of Earth Science, pp. 784-796, Springer, Berlin.

Rampton, V. N. (1988), Quaternary Geology of the Tuktoyaktuk Coastlands, Northwest Territories, Memoir 423, Geological Survey of Canada, Ottawa.

Regmi, P., G. Grosse, M. C. Jones, B. M. Jones, and K. W. Anthony (2012), Characterizing post-drainage succession in thermokarst lake basins on the Seward Peninsula, Alaska with TerraSAR-X backscatter and Landsat-based NDVI data, Remote Sensing, 4(12), 3741-3765, doi:10.3390/rs4123741.

Resio, D., S. Bratos, and E. Thompson (2002), Meteorology and wave climate, in Coastal Engineering Manual, Part II, Hydrodynamics, Chapter II-2, edited by L. Vincent and Z. Demirbilek, Engineer Manual 1110-2-1100, pp. II.2.1 - II.2.72, US Army Corps of Engineers, Washington D.C.

Richards, K. (1996), Samples and cases: generalisation and explanation in geomorphology, in Scientific Nature of Geomorphology: Proceedings of the 27th Binghamton Symposium in Geomorphology, September, 1996, Binghampton, USA, edited by B. Rhoads and C. E. Thorn, pp. 171-190, John Wiley \& Sons Ltd, Chichester.

Riordan, B., D. Verbyla, and A. D. McGuire (2006), Shrinking ponds in subarctic Alaska based on 1950-2002 remotely sensed images, Journal of Geophysical Research: Biogeosciences, 111(G4), G04,002, doi:10.1029/2005JG000150.

Riseborough, D. W. (1990), Soil latent heat as a filter of the climate signal in permafrost, in Proceedings of the Fifth Canadian Permafrost Conference, Quebec, Canada, 6-8 June, 1990, Collection Nordicana No. 54, pp. 199-205, Centre d'études nordiques, Université Laval, Québec City. 
Riseborough, D. W. (2002), The mean annual temperature at the top of permafrost, the TTOP model, and the effect of unfrozen water, Permafrost and Periglacial Processes, 13(2), 137-143, doi:10.1002/ppp.418.

Romanovsky, V. E., and T. E. Osterkamp (1995), Interannual variations of the thermal regime of the active layer and near-surface permafrost in northern Alaska, Permafrost and Periglacial Processes, 6(4), 313-335, doi:10.1002/ppp.3430060404.

Romanovsky, V. E., and T. E. Osterkamp (2000), Effects of unfrozen water on heat and mass transport processes in the active layer and permafrost, Permafrost and Periglacial Processes, 11(3), 219-239, doi:10.1002/1099-1530(200007/09)11:3〈219::AID-PPP352〉3.0.CO;2-7.

Romanovsky, V. E., S. L. Smith, and H. H. Christiansen (2010a), Permafrost thermal state in the polar Northern Hemisphere during the international polar year 2007-2009: a synthesis, Permafrost and Periglacial Processes, 21(2), 106-116, doi:10.1002/ppp.689.

Romanovsky, V. E., D. S. Drozdov, N. G. Oberman, G. V. Malkova, A. L. Kholodov, S. S. Marchenko, N. G. Moskalenko, D. O. Sergeev, N. G. Ukraintseva, A. A. Abramov, D. A. Gilichinsky, and A. A. Vasiliev (2010b), Thermal state of permafrost in russia, Permafrost and Periglacial Processes, 21 (2), 136-155, doi:10.1002/ppp.683.

Rouse, W. R. (1984), Microclimate at Arctic tree line 1. Radiation balance of tundra and forest, Water Resources Research, 20(1), 57-66, doi:10.1029/WR020i001p00057.

Rowland, J. C., B. J. Travis, and C. J. Wilson (2011), The role of advective heat transport in talik development beneath lakes and ponds in discontinuous permafrost, Geophysical Research Letters, 38(17), L17,504, doi:10.1029/2011GL048497.

Roy-Léveillée, P., and C. R. Burn (2010), Permafrost conditions near shorelines of oriented lakes in Old Crow Flats, Yukon Territory, in Proceedings of the Sixth Canadian Permafrost Conference, Calgary, Canada, September 12-16, 2010., pp. 1509-1516, Canadian Geotechnical Society, Calgary.

Roy-Léveillée, P., C. R. Burn, and I. D. McDonald (2014), Vegetation-permafrost relations within the forest-tundra ecotone near Old Crow, northern Yukon, Canada, Permafrost and Periglacial Processes, 25(2), 127-135, doi:10.1002/ppp.1805.

Sannel, A. B. K., and P. Kuhry (2011), Warming-induced destabilization of peat plateau/thermokarst lake complexes, Journal of Geophysical Research: Biogeosciences, 116(G3), G03,035, doi:10.1029/2010JG001635. 
Schaefer, K., H. Lantuit, V. E. Romanovsky, E. A. G. Schuur, and R. Witt (2014), The impact of the permafrost carbon feedback on global climate, Environmental Research Letters, 9(8), 085,003, doi:10.1088/1748-9326/9/8/085003.

Schell, D. M., P. J. Ziemann, and R. D. Miller (1983), Accumulation of peat carbon in the Alaska Arctic Coastal Plain and its role in biological productivity, in Proceedings of the Fourth International Conference on Permafrost, Fairbanks, USA, July 17-22 1983, pp. 1105-1110, National Academy of Sciences, Washington DC.

Schwamborn, G. J., J. K. Dix, J. M. Bull, and V. Rachold (2002), High-resolution seismic and ground penetrating radargeophysical profiling of a thermokarst lake in the western Lena Delta, Northern Siberia, Permafrost and Periglacial Processes, 13(4), 259-269, doi:10.1002/ppp.430.

Seppälä, M. (2004), Wind as a Geomorphic Agent in Cold Climates, Cambridge University Press, Cambridge.

Serreze, M. C., A. H. Lynch, and M. P. Clark (2001), The Arctic frontal zone as seen in the NCEP-NCAR reanalysis, Journal of Climate, 14(7), 1550-1567, doi:10.1175/1520-0442(2001)014〈1550:TAFZAS $\rangle 2.0 . C O ; 2$.

Sheldrick, B. H. (1984), Analytical Methods Manual. Research Branch, LRRI Contribution No. 84-30, Research Branch, Agriculture Canada, Ottawa.

Shur, Y., and T. Zhestkova (2003), Cryogenic structure of a glacio-lacustrine deposit, in Proceedings of the Eighth International Conference on Permafrost, Zurich, Switzerland, July 21-25, 2003, vol. 2, edited by M. Phillips, S. Springman, and L. Arenson, pp. 1051-1056, Balkema Publishers, Lisse.

Shur, Y., K. M. Hinkel, and F. E. Nelson (2005), The transient layer: implications for geocryology and climate-change science, Permafrost and Periglacial Processes, 16(1), 5-17, doi:10.1002/ppp.518.

Smith, L. C., Y. Sheng, G. M. MacDonald, and L. D. Hinzman (2005), Disappearing Arctic lakes, Science, 308(5727), 1429, doi:10.1126/science.1108142.

Smith, L. C., Y. Sheng, and G. M. MacDonald (2007), A first pan-arctic assessment of the influence of glaciation, permafrost, topography and peatlands on northern hemisphere lake distribution, Permafrost and Periglacial Processes, 18(2), 201-208, doi:10.1002/ppp.581.

Smith, M. W. (1975), Microclimatic influences on ground temperatures and permafrost distribution, Mackenzie Delta, Northwest Territories, Canadian Journal of Earth Sciences, 12(8), 1421-1438, doi:10.1139/e75-129.

Smith, M. W. (1976), Permafrost in the Mackenzie Delta, Northwest Territories, Paper 75-28, Geological Survey of Canada, Ottawa. 
Smith, M. W. (1985), Observations of soil freezing and frost heave at Inuvik, Northwest Territories, Canada, Canadian Journal of Earth Sciences, 22(2), 283-290, doi:10.1139/e85-024.

Smith, M. W., and A. R. Tice (1988), Measurement of the unfrozen water conten of soils: comparison of NMR and TDR methods, CRREL report 88-18, US Army Corps of Engineers, Cold Regions Research and Engineering Laboratory, Hanover, $\mathrm{NH}$.

Smith, S., V. Romanovsky, A. Lewkowicz, C. Burn, M. Allard, G. Clow, K. Yoshikawa, and J. Throop (2010), Thermal state of permafrost in North America: a contribution to the International Polar Year, Permafrost and Periglacial Processes, 21(2), 117-135, doi:10.1002/ppp.690.

Stevens, C. W., B. J. Moorman, and S. M. Solomon (2010), Modeling ground thermal conditions and the limit of permafrost within the nearshore zone of the Mackenzie Delta, Canada, Journal of Geophysical Research, 115(F4), doi:10.1029/2010JF001786.

Stieglitz, M., S. J. Dry, V. E. Romanovsky, and T. E. Osterkamp (2003), The role of snow cover in the warming of Arctic permafrost, Geophysical Research Letters, 30 (13), 1721, doi:10.1029/2003GL017337.

Strahler, A. N. (1954), Statistical analysis in geomorphic research, Journal of Geology, 62(1), 1-25, doi:10.1086/626131.

Sturm, M., J. Schimel, G. Michaelson, J. M. Welker, S. F. Oberbauer, G. E. Liston, J. Fahnestock, and V. E. Romanovsky (2005), Winter biological processes could help convert Arctic tundra to shrubland, BioScience, 55(1), 17-26, doi:10.1641/0006-3568(2005)055[0017:WBPCHC]2.0.CO;2.

Sturtevant, C. S., and W. C. Oechel (2013), Spatial variation in landscape-level $\mathrm{CO}_{2}$ and $\mathrm{CH}_{4}$ fluxes from Arctic coastal tundra: influence from vegetation, wetness, and the thaw lake cycle, Global Change Biology, 19(9), 2853-2866, doi:10.1111/gcb.12247.

Tarnocai, C., J. G. Canadell, E. A. G. Schuur, P. Kuhry, G. Mazhitova, and S. Zimov (2009), Soil organic carbon pools in the northern circumpolar permafrost region, Global Biogeochemical Cycles, 23(2), GB2023, doi:10.1029/2008GB003327.

Task Force on Northern Research (2000), From Crisis to Opportunity: Rebuilding Canadas Role in Northern Research, Final report to NSERC and SSHRC, NSERC, Ottawa.

Taylor, A., S. Dallimore, and J. Wright (2008), Thermal impact of Holocene lakes on a permafrost landscape, Mackenzie Delta, Canada, in Proceedings of the 9th International Conference on Permafrost, Fairbanks, Alaska, 29 June-3 July 2008, 
Vol. 2, edited by D. Kane and K. M. Hinkel, pp. 1757-1762, Institute for Northern Engineering, University of Alaska Fairbanks, Fairbanks.

The Secretariat of the Convention on Wetlands (2014), The List of Wetlands of International Importance, http://ramsar.org/pdf/sitelist.pdf, accessed: 2014-09-17.

Tice, A. R., D. M. Anderson, and A. Banin (1976), The prediction of unfrozen water contents in frozen soils from liquid limit determinations, CRREL report 76-8, U.S. Army Cold Regions Research and Engineering Laboratory, Hanover, NH.

Timoney, K., G. P. Kershaw, and D. Olesen (1992a), Late winter snow-landscape relationships in the subarctic near Hoarfrost River, Great Slave Lake, Northwest Territories, Canada, Water Resources Research, 28(7), 1991-1998, doi:10.1029/92WR00534.

Timoney, K. P., G. H. La Roi, S. C. Zoltai, and A. L. Robinson (1992b), The high subarctic forest-tundra of northwestern Canada: position, width, and vegetation gradients in relation to climate, Arctic, 45(1), 1-9.

Tomirdiaro, S. V., and V. K. Ryabchun (1973), Lake thermokarst on the Lower Anadyr lowland, in Proceedings of the Second International Conference on Permafrost, Yakutsk, USSR, 13-28 July, 1973, USSR Contribution, edited by F. Sanger and P. Hyde, pp. 94-100, National Academy of Sciences, Washington DC.

Tsouvalis, J., and C. Waterton (2012), Building participation upon critique: The Loweswater Care Project, Cumbria, UK, Environmental Modelling \&5 Software, 36, 111-121, doi:10.1016/j.envsoft.2012.01.018.

Turner, K. W., B. B. Wolfe, and T. W. D. Edwards (2010), Characterizing the role of hydrological processes on lake water balances in the Old Crow Flats, Yukon Territory, Canada, using water isotope tracers, Journal of Hydrology, 386(14), 103-117, doi:10.1016/j.jhydrol.2010.03.012.

Turner, K. W., B. B. Wolfe, T. W. D. Edwards, T. C. Lantz, R. I. Hall, and G. Larocque (2014a), Controls on water balance of shallow thermokarst lakes and their relations with catchment characteristics: a multi-year, landscape-scale assessment based on water isotope tracers and remote sensing in Old Crow Flats, Yukon (Canada), Global Change Biology, 20(5), 1585-1603, doi:10.1111/gcb.12465.

Turner, K. W., T. W. D. Edwards, and B. B. Wolfe (2014b), Characterising runoff generation processes in a lake-rich thermokarst landscape (Old Crow Flats, Yukon, Canada) using $\delta^{18} \mathrm{O}, \delta^{2} \mathrm{H}$ and d-excess measurements, Permafrost and Periglacial Processes, 25(1), 53-59, doi:10.1002/ppp.1802. 
Ukraintseva, N. G., D. S. Drozdov, K. A. Popov, A. G. Gravis, and G. V. Matyshak (2011), Landscape indication of local permafrost variability (Urengoy Territory, West Siberia), Earth Cryosphere, 15(4), 32-35.

Ulrich, M., G. Grosse, J. Strauss, and L. Schirrmeister (2014), Quantifying wedge-ice volumes in Yedoma and thermokarst basin deposits, Permafrost and Periglacial Processes, 25, 151-161, doi:10.1002/ppp.1810.

UMA Engineering (1986), Old Crow Erosion Study, Report to Community and Transportation Services, Government of Yukon, Whitehorse.

van der Molen, M. K., J. van Huissteden, F. J. W. Parmentier, A. M. R. Petrescu, A. J. Dolman, T. C. Maximov, A. V. Kononov, S. V. Karsanaev, and D. A. Suzdalov (2007), The growing season greenhouse gas balance of a continental tundra site in the Indigirka lowlands, NE Siberia, Biogeosciences, 4(6), 985-1003, doi:10.5194/bg-4-985-2007.

van Everdingen, R. (Ed.) (1998), Multi-language glossary of permafrost and related ground-ice terms, National Snow and Ice Data Center, Boulder.

van Huissteden, J., C. Berrittella, F. J. W. Parmentier, Y. Mi, T. C. Maximov, and A. J. Dolman (2011), Methane emissions from permafrost thaw lakes limited by lake drainage, Nature Climate Change, 1(2), 119-123, doi:10.1038/nclimate1101.

Wahl, H. (2004), Climate, in Ecoregions of the Yukon Territory: Biophysical properties of Yukon landscapes, edited by C. Smith, J. C. Meikle, and C. F. Roots, PARC Technical Bulletin No. 04-01, pp. 19-23, Agriculture and Agri-Food Canada, Summerland.

Walter, K. M., S. A. Zimov, J. P. Chanton, D. Verbyla, and F. S. Chapin (2006), Methane bubbling from Siberian thaw lakes as a positive feedback to climate warming, Nature, 443(7107), 71-75, doi:10.1038/nature05040.

Walter, K. M., L. C. Smith, and F. S. Chapin (2007), Methane bubbling from northern lakes: present and future contributions to the global methane budget, Philosophical Transactions of the Royal Society A: Mathematical, Physical and Engineering Sciences, 365(1856), 1657-1676, doi:10.1098/rsta.2007.2036.

Walter-Anthony, K. M., S. A. Zimov, G. Grosse, M. C. Jones, P. M. Anthony, F. S. I. Chapin, J. C. Finlay, M. C. Mack, S. Davydov, P. Frenzel, and S. Frolking (2014), A shift of thermokarst lakes from carbon sources to sinks during the Holocene Epoch, Nature, 511(7510), 452-456, doi:10.1038/nature13560.

West, J. J., and L. J. Plug (2008), Time-dependent morphology of thaw lakes and taliks in deep and shallow ground ice, Journal of Geophysical Research: Earth Surface, 113(F1), F01,009, doi:10.1029/2006JF000696. 
Williams, P. J., and M. W. Smith (1989), The Frozen Earth: Fundamentals of Geocryology, Cambridge University Press, Cambridge.

Wilmsen, C., W. F. Elmendorf, L. Fisher, J. Ross, B. Sarathy, and G. Wells (Eds.) (2008), Partnerships for Empowerment: Participatory Research for Community-based Natural Resource Management, Routledge, London; Sterling, VA.

Wolfe, B. B., M. M. Humphries, M. F. Pisaric, A. M. Balasubramaniam, C. R. Burn, L. Chan, D. Cooley, D. G. Froese, S. Graupe, R. I. Hall, and others (2011), Environmental change and traditional use of the Old Crow Flats in northern Canada: an IPY opportunity to meet the challenges of the new northern research paradigm, Arctic, 64(1), 127-135.

Yoshikawa, K., and L. D. Hinzman (2003), Shrinking thermokarst ponds and groundwater dynamics in discontinuous permafrost near Council, Alaska, Permafrost and Periglacial Processes, 14(2), 151-160, doi:10.1002/ppp.451.

Yukon Ecoregions Working Group (2004), Ecoregions of the Yukon Territory: Biophysical Properties of Yukon Landscapes, no. 04-01 in PARC Technical Bulletin, Agriculture \& Agri-Food Canada, Summerland.

Zazula, G. D., A. Duk-Rodkin, C. E. Schweger, and R. E. Morlan (2004), Late Pleistocene chronology of Glacial Lake Old Crow and the north-west margin of the Laurentide ice sheet, in Quaternary Glaciations-Extent and Chronology Part II: North America, Developments in Quaternary Sciences, vol. 2B, edited by J. Ehlers and P.L. Gibbard, pp. 347-362, Elsevier, London.

Zhan, S., R. A. Beck, K. M. Hinkel, H. Liu, and B. M. Jones (2014), Spatio-temporal analysis of gyres in oriented lakes on the Arctic coastal plain of northern Alaska based on remotely sensed images, Remote Sensing, 6(10), 9170-9193, doi:10.3390/rs6109170.

Zhou, W., and S. Huang (2004), Modeling impacts of thaw lakes to ground thermal regime in northern Alaska, Journal of Cold Regions Engineering, 18(2), 70-87, doi:10.1061/(ASCE)0887-381X(2004)18:2(70).

Zimov, S. A., E. A. G. Schuur, and F. S. Chapin (2006), Permafrost and the global carbon budget, Science, 312(5780), 1612-1613, doi:10.1126/science.1128908. 


\section{Appendix A}

\section{Signed statements of co-authorship}

\section{STATEMENT OF CO-AUTHORSHIP}

As co-author of 'Vegetation-permafrost relations within the treeline ecotone near Old Crow, northern Yukon, Canada', published in the peer-reviewed journal Permafrost and Periglacial Processes, of 'Near-shore talik development beneath expanding thermokarst lakes, Old Crow Flats, Yukon, Canada', submitted for publication to the Journal of Geophysical Research, and of 'Topography of drained lake basins in the Old Crow Flats, Y.T.', to be submitted for publication to Earth Surface Processes and Landforms, I, Christopher Robert Burn, acknowledge Pascale Roy-Léveillée as the lead contributing author of these manuscripts. Pascale designed and performed the field study, obtained and analysed all data, and wrote and revised the manuscripts.

I, Christopher Robert Burn, have contributed to the published papers and the papers submitted for publication in this thesis as supervisor of Pascale Roy-Léveillée during the doctoral program in geography. This has entailed discussion, criticism, advice, and editorial contributions to the design, field investigations, analysis, and writing of this thesis. These activities have been entirely consistent with the role of thesis supervisor.

As co-author of 'Vegetation-permafrost relations within the treeline ecotone near Old Crow, northern Yukon, Canada', published in the peer-reviewed journal Permafrost and Periglacial Processes, I, Ian Douglas McDonald, acknowledge Pascale Roy-Léveillée as the manuscripts' lead contributing author. Pascale designed and performed the field study, obtained and analysed all data, and wrote and revised the manuscripts.

I, Ian Douglas McDonald, have contributed to the published paper in this thesis as a northern research partner. This has entailed contribution to the collection of field data, discussion, criticism, and editorial contributions to the design of field investigations, and writing of the manuscript. These activities have been entirely consistent with the role of northern research partner.

These manuscripts have engaged topics that have been the subject of some discussion in the literature and represent significant contributions to the understanding of permafrost and permafrost-related processes. For this reason we fully support the inclusion of these articles as a component in Pascale's doctoral thesis.

Christopher Robert Burn

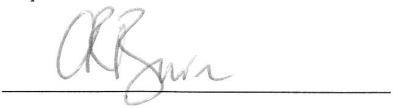

Signature

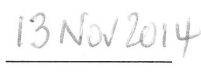

Date

Ian Douglas McDonald 


\section{STATEMENT OF CO-AUTHORSHIP}

As co-author of 'Vegetation-permafrost relations within the treeline ecotone near Old Crow, northern Yukon, Canada', published in the peer-reviewed journal Permafrost and Periglacial Processes, of 'Near-shore talik development beneath expanding thermokarst lakes, Old Crow Flats, Yukon, Canada', submitted for publication to the Journal of Geophysical Research, and of 'Topography of drained lake basins in the Old Crow Flats, Y.T.', to be submitted for publication to Earth Surface Processes and Landforms, I, Christopher Robert Burn, acknowledge Pascale Roy-Léveillée as the lead contributing author of these manuscripts. Pascale designed and performed the field study, obtained and analysed all data, and wrote and revised the manuscripts.

I, Christopher Robert Burn, have contributed to the published papers and the papers submitted for publication in this thesis as supervisor of Pascale Roy-Léveillée during the doctoral program in geography. This has entailed discussion, criticism, advice, and editorial contributions to the design, field investigations, analysis, and writing of this thesis. These activities have been entirely consistent with the role of thesis supervisor.

As co-author of 'Vegetation-permafrost relations within the treeline ecotone near Old Crow, northern Yukon, Canada', published in the peer-reviewed journal Permafrost and Periglacial Processes, I, Ian Douglas McDonald, acknowledge Pascale Roy-Léveillée as the manuscripts' lead contributing author. Pascale designed and performed the field study, obtained and analysed all data, and wrote and revised the manuscripts.

I, Ian Douglas McDonald, have contributed to the published paper in this thesis as a northern research partner. This has entailed contribution to the collection of field data, discussion, criticism, and editorial contributions to the design of field investigations, and writing of the manuscript. These activities have been entirely consistent with the role of northern research partner.

These manuscripts have engaged topics that have been the subject of some discussion in the literature and represent significant contributions to the understanding of permafrost and permafrost-related processes. For this reason we fully support the inclusion of these articles as a component in Pascale's doctoral thesis.

Christopher Robert Burn

Ian Douglas McDonald

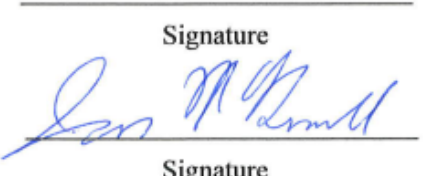

Signature

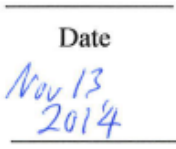

Date 


\section{Appendix B}

\section{Other contributions related to this research}

Non-refereed research contributions related to this thesis are listed below, including community outreach material. The research presented in this thesis was part of an International Polar Year Project led by the Vuntut Gwitchin First Nation. Community outreach was a major component of the research communication component of the project.

\section{Articles}

Roy-Léveillée P, Burn CR. (2010) Permafrost conditions near shorelines of oriented lakes in Old Crow Flats, Yukon Territory. In 63rd Canadian Geotechnical Conference and 6th Canadian Permafrost Conference, Calgary, AB, Sept. 12-16, 2010, Canadian Geotechnical Society: Richmond, BC. pp. 1509-1516.

Wolfe BB, Humphries MM, Pisaric MFJ, Balasubramaniam AM, Burn CR, Chan L, Cooley D, Froese DG, Graupe S, Hall RI, Lantz T, Porter TJ, Roy-Léveillée

P, Turner KW, Wesche SD, Williams M. (2011) Environmental Change and Traditional Use of the Old Crow Flats in Northern Canada: An IPY Opportunity to Meet the Challenges of the New Northern Research Paradigm. Arctic, 64: 127-135.

\section{Conference presentations}

Roy-Léveillée P, Burn CR, Humphreys E, Braul Z. (2014) Near-shore talik geometry beneath thermokarst lakes in the Old Crow Flats, Northern Yukon. THAW 2014 Thermokarst Aquatic Ecosystem Workshop, March 12-15, 2014, Quebec City, QC. Roy-Léveillée P. (2014) Internal topography of drained lake basins in the Old 
Crow Flats, northern Yukon: an alternative hypothesis. Ottawa-Carleton Student Northern Research Symposium, February 6th, 2014, Ottawa, ON.. Braul Z, Humphreys E, Roy-Léveillée P. (2013) The organic carbon content and decomposition potential of tundra soil eroding into a thermokarst lake. Canadian Society of Soil Science Annual Meeting, July 23-25, 2013, Winnipeg, Manitoba.

Roy-Léveillée P, Burn CR. (2012) Talik geometry and permafrost degradation under thermokarst lakes in the Old Crow Flats, Yukon Territory, Canada. IPY 2012: From Knowledge to Action, April 22-27, 2012, Montreal, QC.

Roy-Léveillée P, Burn CR. (2012) The internal topography of drained thermokarst lake basins in Old Crow Flats, Yukon. Ottawa-Carleton Northern Research Symposium, March 2, 2012, University of Ottawa, Ottawa, ON.

Roy-Léveillée P, Burn CR. (2011) Talik geometry and permafrost degradation under thermokarst lakes in Old Crow Flats, Y.T. Ottawa-Carleton Northern Research Symposium, March 4, 2011, Carleton University, Ottawa, Ontario. Roy-Léveillée P. (2011) Shape and orientation of the lakes of Old Crow Flats, Yukon, Canada. Permafrost Young Researcher Scientific Meeting, April 14, 2011, Longyearbyen, Svalbard.

Braul Z, Humphreys E, Roy-Léveillée P. (2011) Carbon and decomposition potential in tundra soils near Old Crow, Yukon. Canadian Geophysical Union Scientific Meeting, May 15-18, 2011, Banff, Alberta.

Roy-Léveillée P, Burn CR. (2009) Permafrost near lake shorelines in Old Crow Flats, Yukon. Communities of change: Building an IPY legacy, ACUNS Student Conference on Northern Studies, October 2-5, 2009, Whitehorse, Yukon.

Roy-Léveillée P, Burn CR. (2008) Permafrost and lakes in the Old Crow Flats. International Polar Year joint project in the Old Crow Flats scientific meeting, October 2008, Carleton University, Ottawa, ON.

Roy-Léveillée P, Burn CR. (2007) On the road to becoming a northern researcher. NSERC Northern Research Chair Annual Meeting. October 19, 2007, 
Saskatoon, SK.

Roy-Léveillée P, Burn CR. (2007) Assessing regional snow depth and ground-frost conditions using an accessible reference site, Blackstone Uplands, Yukon, Canada. Melting Boundaries: Carrying effective research in the circumpolar world, ACUNS Student Conference on Northern Studies, October 19-21 2007, Saskatoon, SK.

Roy-Léveillée P, Burn CR. (2007) Snow-pack development and ground-frost penetration in the Blackstone Uplands, Yukon Territory, Canada. Conference on Science in the Changing North, April 2007, Yellowknife, NT.

Roy-Léveillée P. (2006) Investigating how topography and vegetation structure affect early winter snow-pack development and ground freezing in the Blackstone Uplands, Yukon. Yukon Biodiversity Round-Up, December 2006, Whitehorse, Yukon.

\section{Outreach material: written reports and community presentations}

Roy-Léveillée P, Burn CR. (2010) Permafrost degradation near eroding lake shorelines, and topographical patterns in drained lake basins. Progress Report for the Vuntut Gwitchin First Nation Natural Resources Department, 4 p.

Roy-Léveillée P, Burn CR. (2009) Permafrost near lakeshores in Old Crow Flats. In Yeendoo Nanh Nakhweenjit K'atr'ahanahtyaa (Looking after the land for the future): Environmental Change and Traditional Use of the Old Crow Flats in Northern Canada, Progress Report, February 2009, pp. 13-14.

Roy-Léveillée P, Burn CR. (2008) Wind, water, and frozen earth: permafrost degradation along lake shorelines. In Yeendoo Nanh Nakhweenjit K'atr'ahanahtyaa (Looking after the land for the future): Environmental Change and Traditional Use of the Old Crow Flats in Northern Canada, Progress Report, February 2008, pp. $9-10$.

Roy-Léveillée P, Frost S, Burn CR. (2010) Permafrost and Lakes in the Old 
Crow Flats, Yukon, presentations of preliminary results for local community members. Yeendoo Nanh Nakhweenjit K'atr'ahanahtyaa community meetings, January 2010, Old Crow, Yukon.

Roy-Léveillée P, Burn CR. (2009) Permafrost and Lakes in the Old Crow Flats, an introduction to permafrost research for local community members. Yeendoo Nanh Nakhweenjit K'atr'ahanahtyaa VGG-IPY meeting, January 18-22 2009, Old Crow, Yukon.

Roy-Léveillée P, (2009) Will the ground melt away? An interactive workshop on what may happen to permafrost when climate changes for the students of the Chief Zzhe Gittlit Elementary School. Yeendoo Nanh Nakhweenjit K'atr'ahanahtyaa VGG-IPY meeting, January 18-22 2009, Old Crow, Yukon. 